\title{
GROUNDWATER QUALITY AND FARM NITROGEN MANAGEMENT ON THE WEST COAST, SOUTH ISLAND, NEW ZEALAND.
}

Tim Baker

A thesis submitted to the Victoria University of Wellington in partial fulfillment of the requirements for the degree of Master of Science with honours in Physical Geography. 


\section{ABSTRACT}

Dairy farming in the West Coast region has undergone substantial intensification over the last decade. Associated with this intensification has been an increased use of nitrogen fertiliser and an increasing number of farms applying dairy shed effluent (DSE) to land. The aim of this project was to assess the current and potential effects of these practices.

Groundwater quality in the most intensive dairying areas on the West Coast was assessed through the monitoring of twenty-two bores on four occasions in 2001. Elevated $\left(>1 \mathrm{~g} / \mathrm{m}^{3}\right)$ nitrate-nitrogen concentrations were found in nineteen of these bores (54 of 74 samples, $72 \%$ ). The only long-term data available, from 3 bores, showed significant increasing trends in nitrate-nitrogen (e.g. $0.41 \mathrm{~g} / \mathrm{m}^{3} / \mathrm{yr}$ in the Bertacco bore) and chloride over the period September 1998 - June 2003. Spatially isolated occurrences of microbial contamination were also recorded: in 7 bores and $12 \%$ of all samples analysed. Overall, groundwater quality of the shallow unconfined groundwater of the Kowhitirangi area was of better quality, and less affected by landuse practices, than the deeper unconfined aquifers of the Grey and Inangahua Valleys.

Nitrogen isotope analysis indicated the source of the nitrate-nitrogen was likely to be from a fertiliser or soil organic nitrogen source (average $\delta^{15} \mathrm{~N}$ of 3.5\%); however, the significant increasing trends of chloride (e.g. $0.50 \mathrm{~g} / \mathrm{m}^{3} / \mathrm{yr}$ in the Bertacco bore, 0.22 $\mathrm{g} / \mathrm{m}^{3} / \mathrm{yr}$ in the Coleman/Lyndale bore) suggest an effluent-based source is affecting groundwater quality in the Kowhitirangi and Grey Valley areas.

Groundwater dating, using chloroflurocarbons, suggested that the groundwater in the river recharge dominated shallow aquifer of the Kowhitirangi area is approximately 7 years old. In the deeper unconfined aquifers of the Grey Valley it is approximately 12 years old. These results suggest that the full effects of landuse intensification over the past decade are yet to been seen in terms of changes in groundwater quality.

Land application of DSE is currently managed through a regional permitted activities rule that sets a maximum DSE nitrogen-loading rate of $275 \mathrm{kgN} / \mathrm{ha} / \mathrm{yr}$. An evaluation of this rate through the use of the NLE and OVERSEER nitrate leaching models suggested that this rate may be sustainable in the future. However, the lack of control over nitrogen fertiliser application rates and detailed (West Coast-specific) data on the rates of complex nitrogen transformations that occur following DSE and nitrogen fertiliser application warrant further research. 


\section{ACKNOWLEDGEMENTS}

Thanks must first go to my supervisor, Dr Richard Hawke for his guidance, support and most of all patience throughout this project. Your ideas, knowledge and editing efforts are truly appreciated.

Thanks to the West Coast Regional Council, especially Trevor James, who gave me the opportunity to do this project, and provided the funding and field assistance. I trust the results will be of value to the council.

A big thanks to all my friends, for your endless support, encouragement and gentle prodding throughout the project, especially those Phys-G's from honours year and Jeremy Piper and Jordy Hendrikx, for their help in the field. They were good times, I just managed to extend them a bit.

Thanks must also go to all my friends, colleagues and flatmates in Masterton where I finished off this thesis, and a special thanks to Summer Warr, whose support and guidance towards the end was invaluable.

Finally a big thanks to my family, their encouragement and support was unwavering, I can't thank you enough. 


\section{TABLE OF CONTENTS}

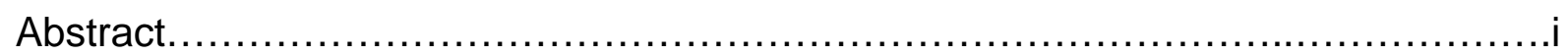

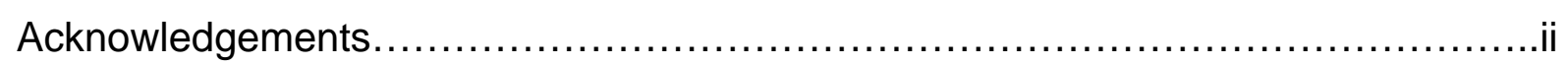

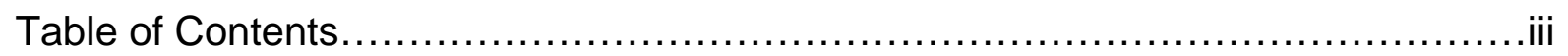

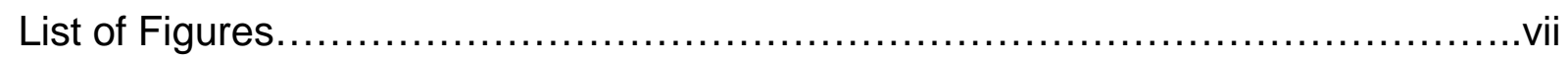

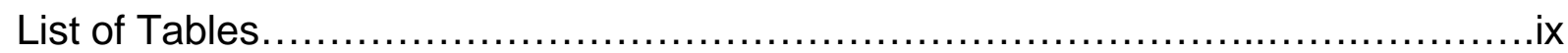

1 INTRODUCTION ................................................................1

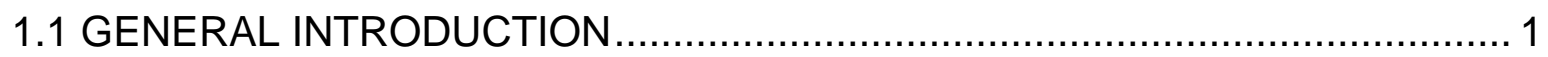

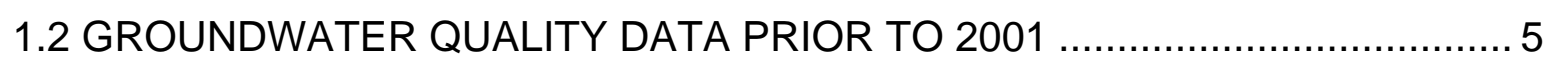

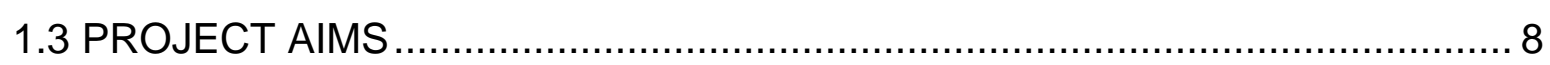

2 STUDY AREA ................................................................10

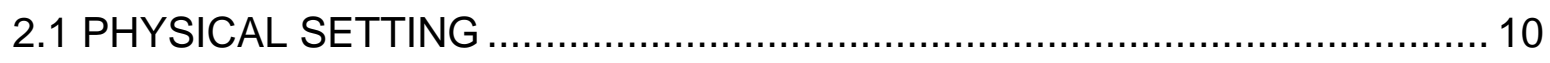

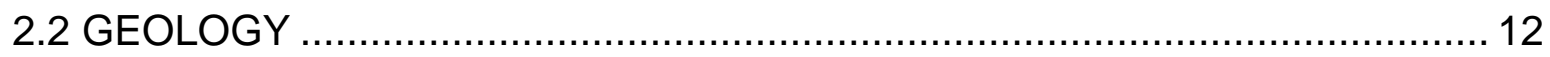

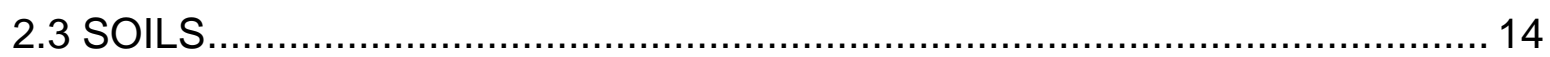

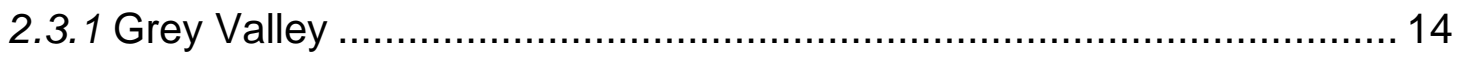

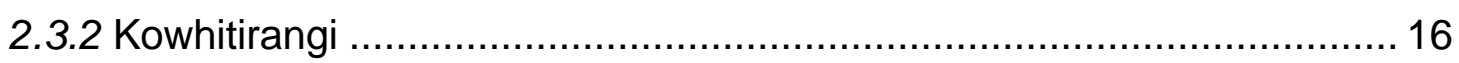

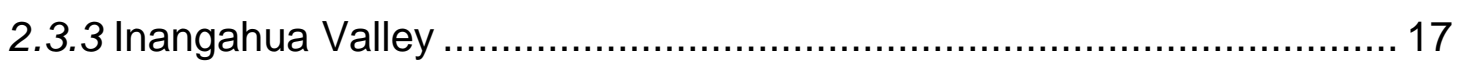

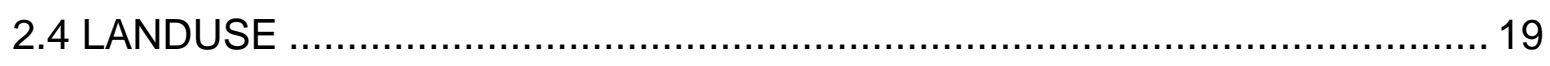

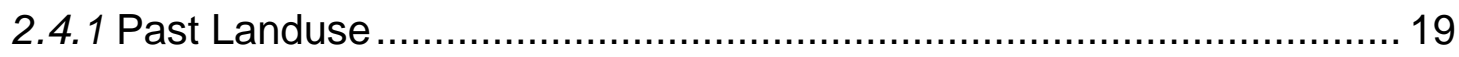

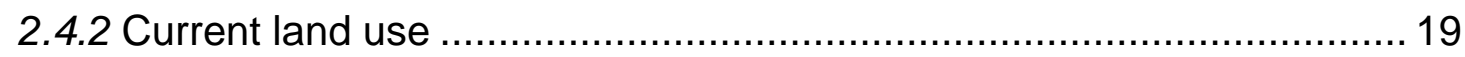

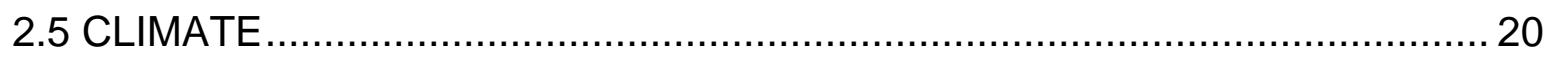

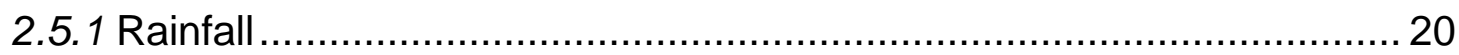

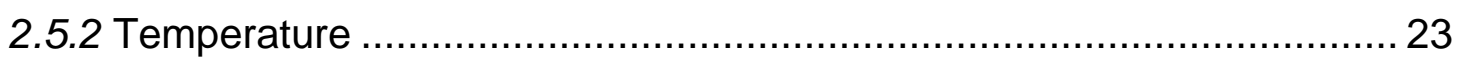

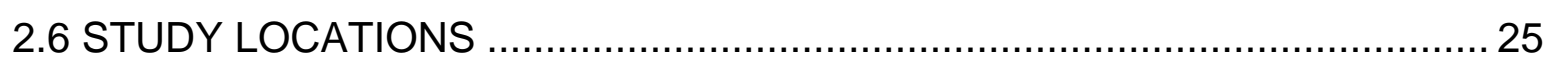

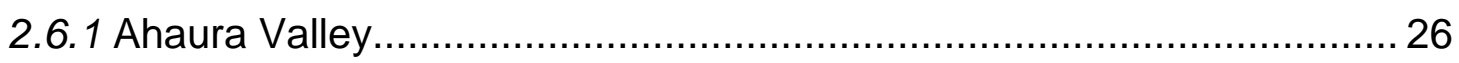

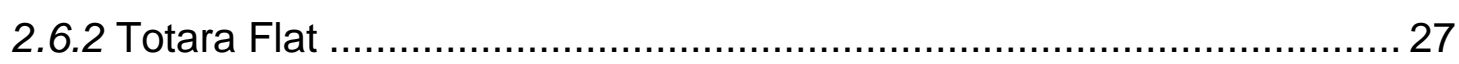

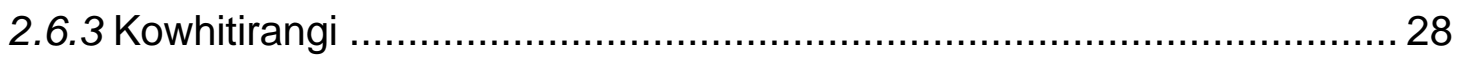

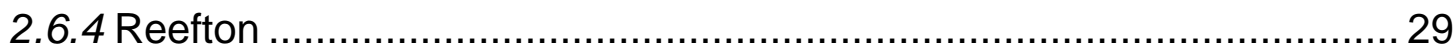




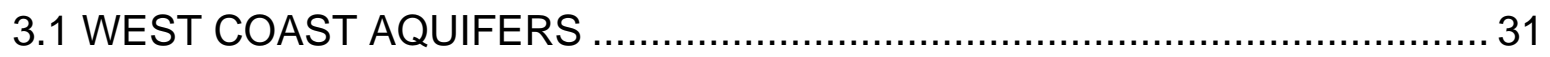

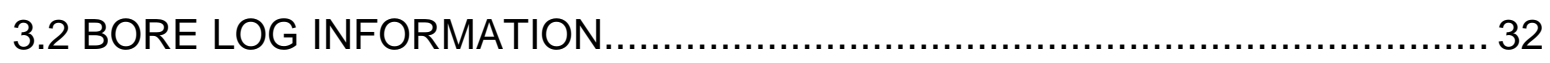

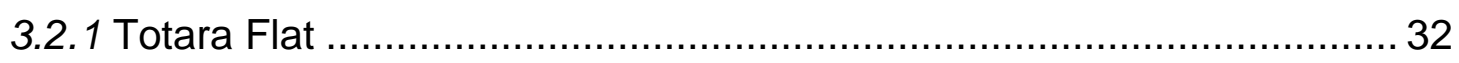

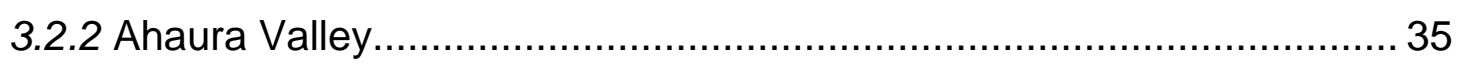

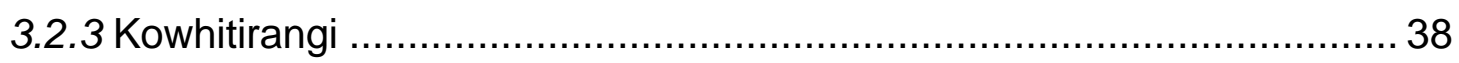

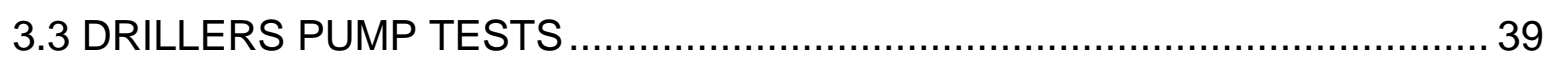

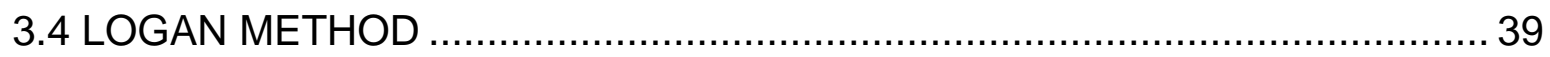

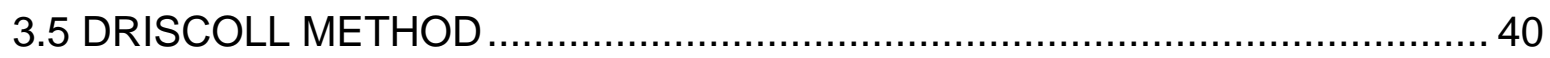

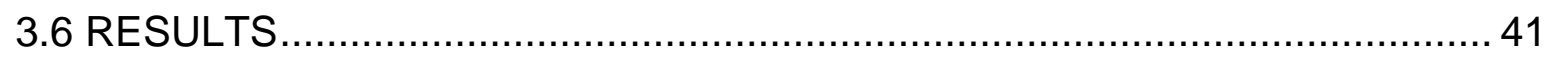

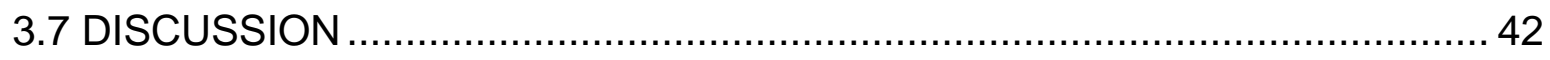

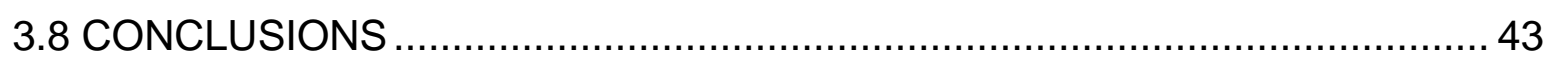

4 GROUNDWATER QUALITY ...........................................44

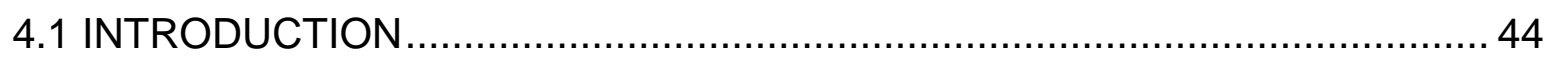

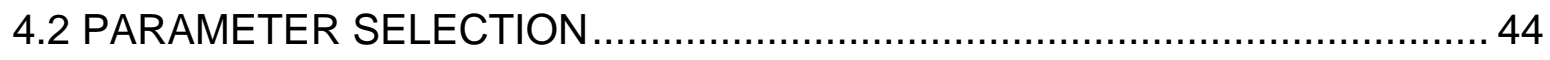

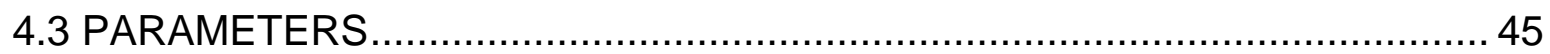

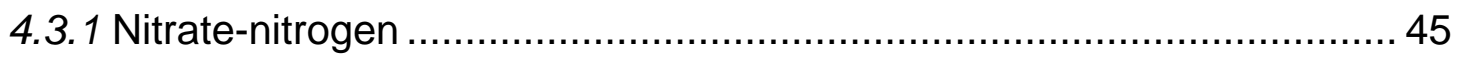

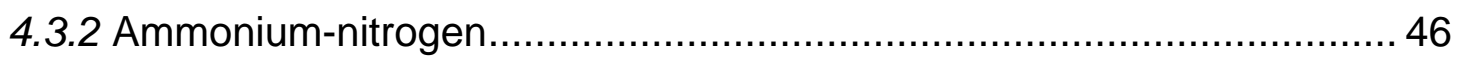

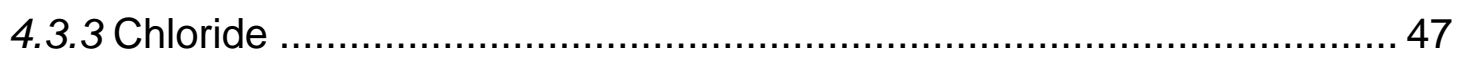

4.3.4 Dissolved Reactive Phosphorus ................................................... 47

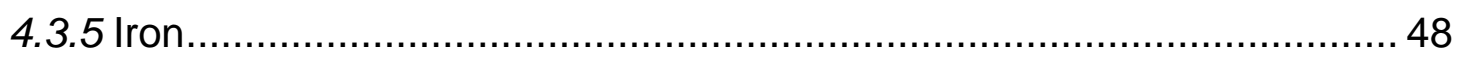

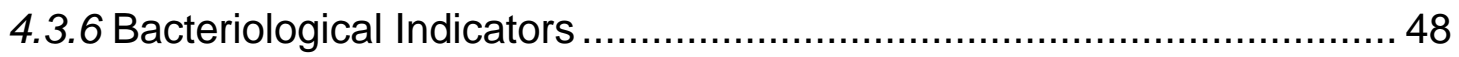

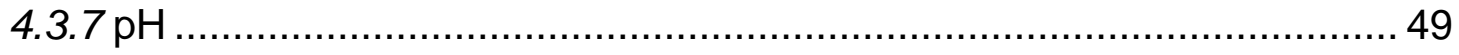

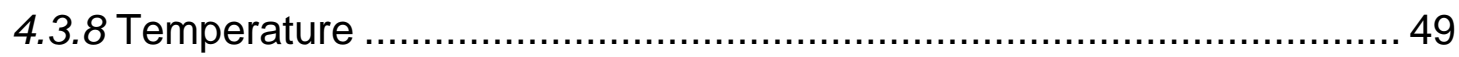

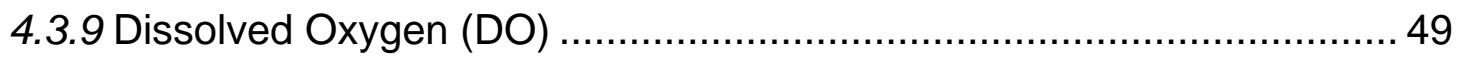

4.3.10 Electrical Conductivity (EC)....................................................... 50

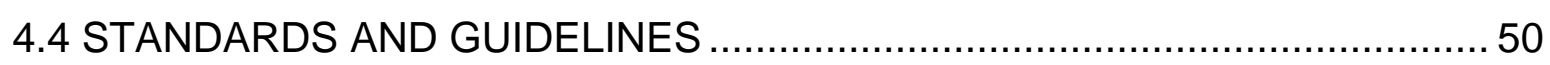

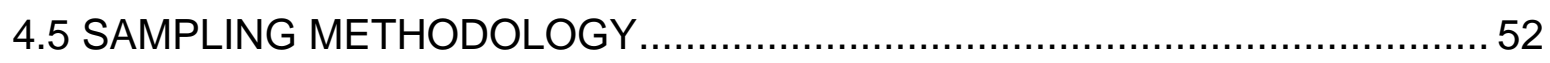

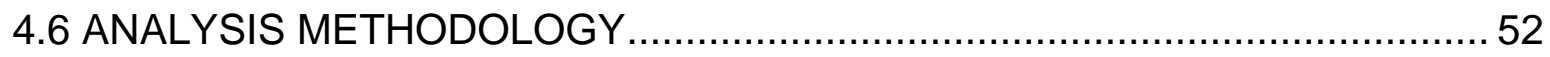

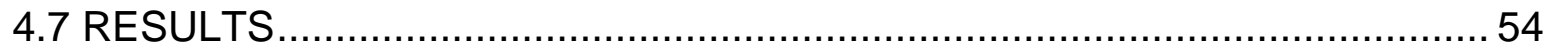

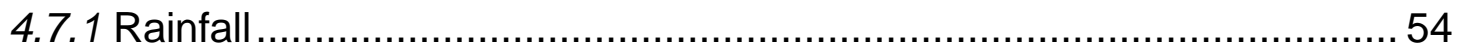

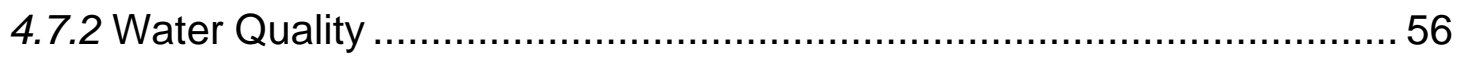




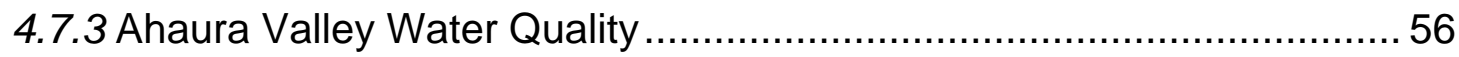

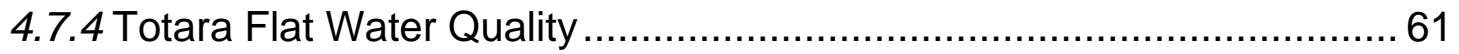

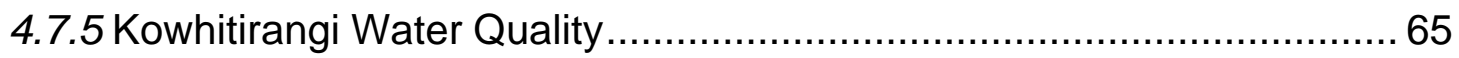

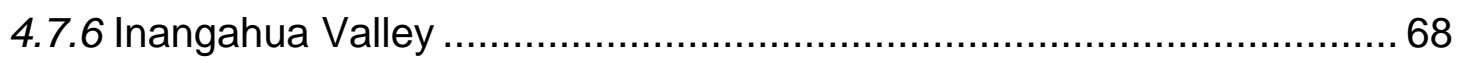

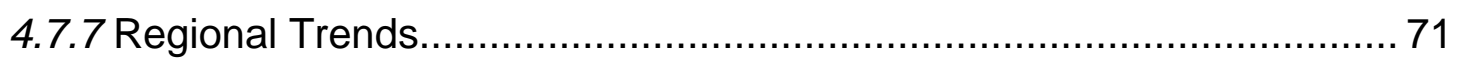

4.7.8 Variations in nitrate-nitrogen concentrations with depth...................... 72

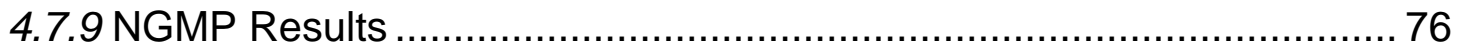

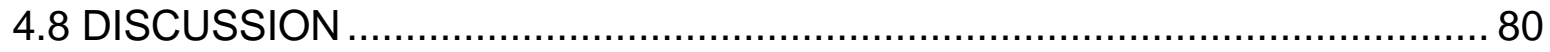

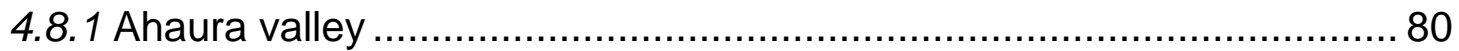

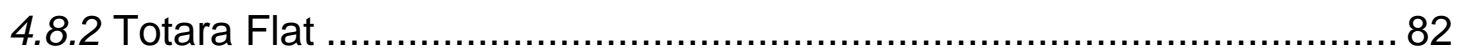

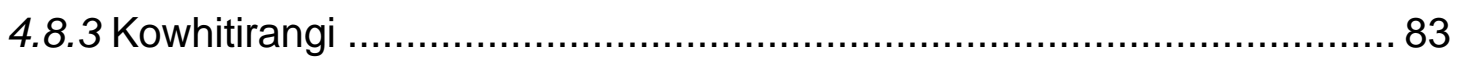

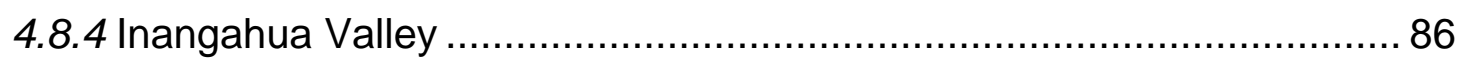

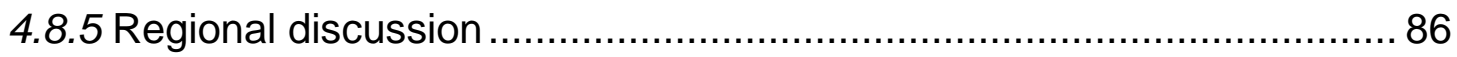

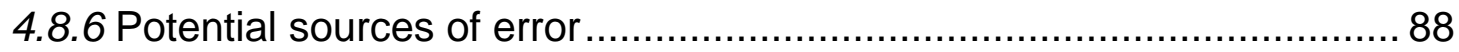

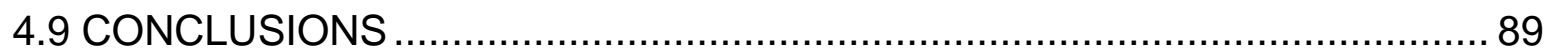

5 AGE DATING AND ISOTOPE ANALYSIS ........................92

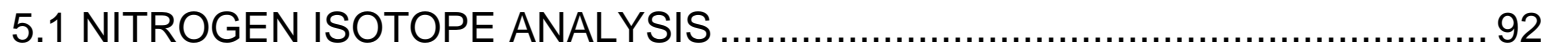

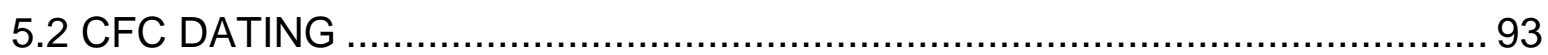

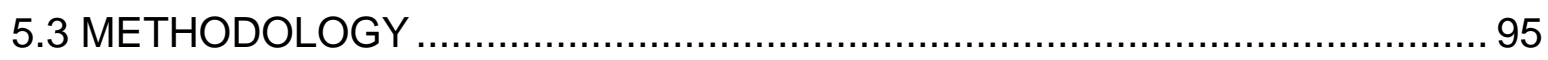

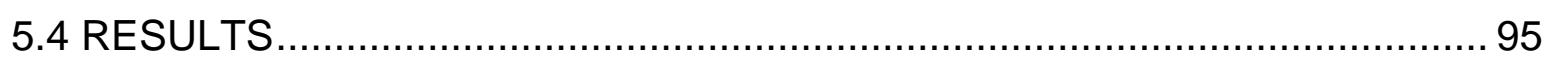

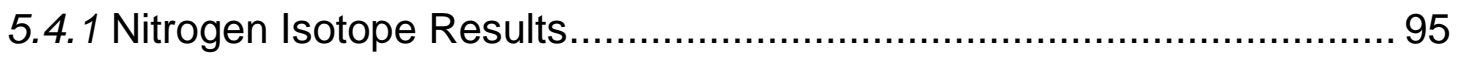

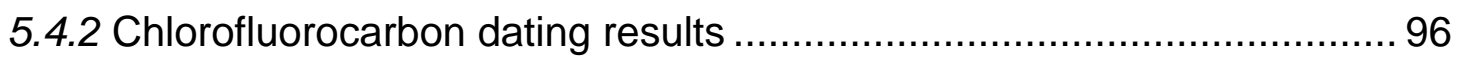

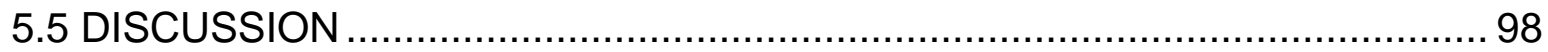

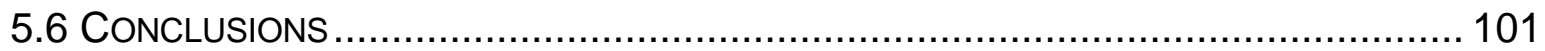

\section{NITROGEN LEACHING AND APPLICATION RATES ......103}

6.1 EFFECTS OF ELEVATED NITRATE LEVELS IN GROUNDWATER ........... 104

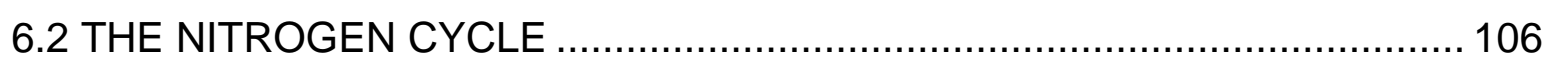

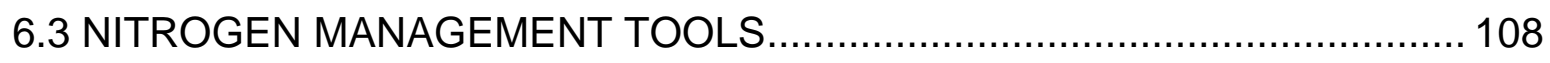

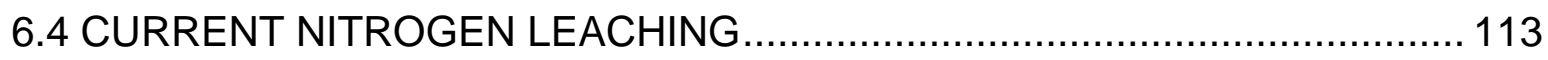

6.5 THE NITROGEN LEACHING ESTIMATION (NLE) MODEL ...................... 113

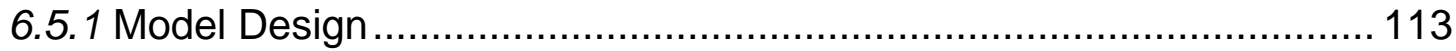

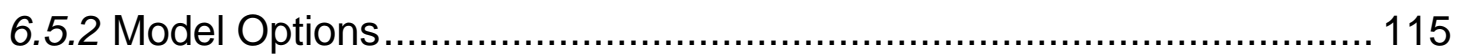


6.5.3 Explanation of inputs used in the NLE .......................................... 116

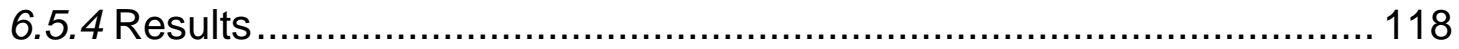

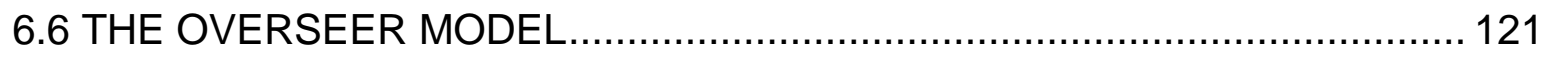

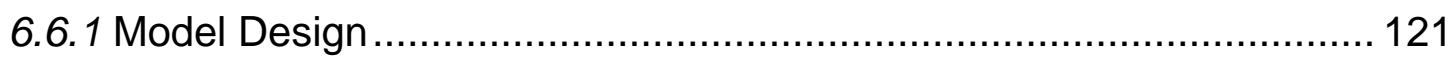

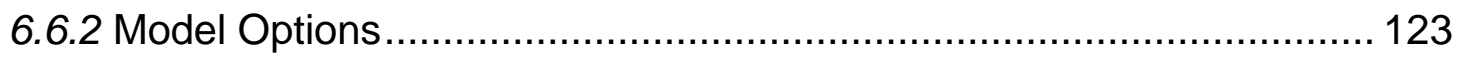

6.6.3 Inputs used in the OVERSEER model ............................................ 123

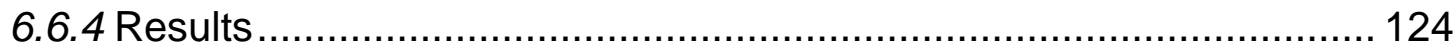

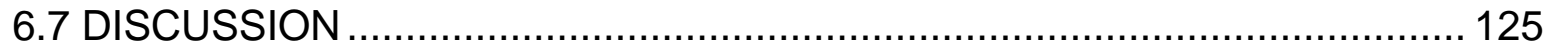

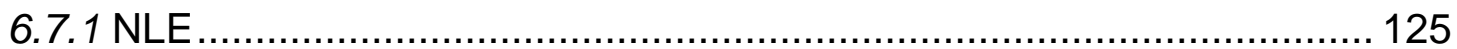

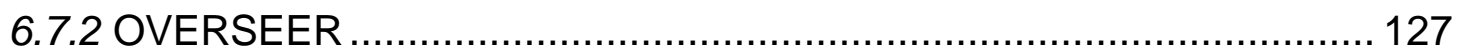

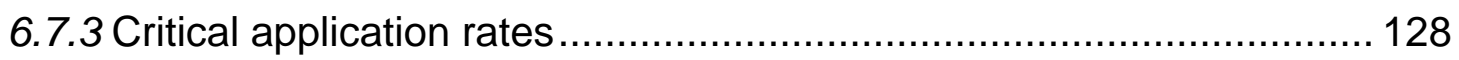

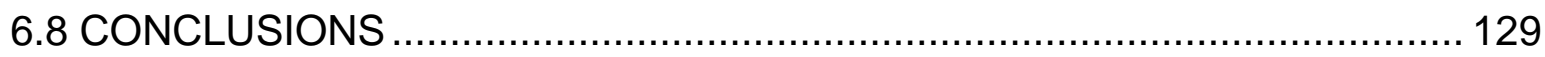

7 SUMMARY AND CONCLUSIONS ..................................132

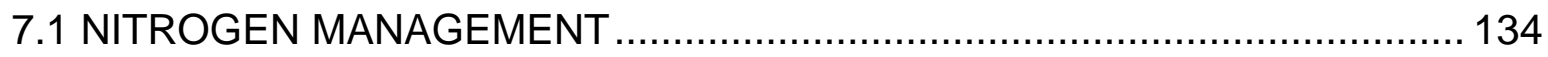

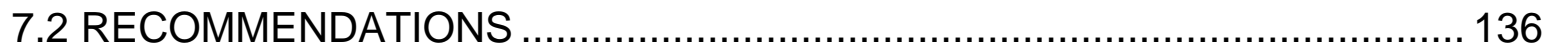

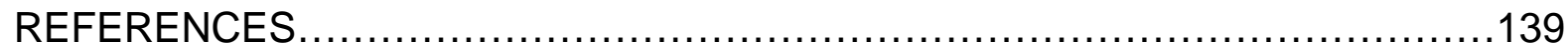

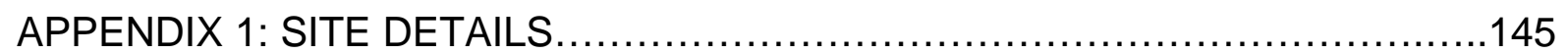

APPENDIX 2: GROUNDWATER QUALITY RESULTS .............................155

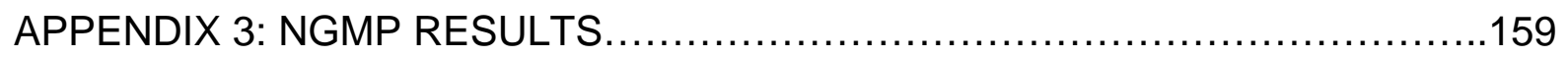




\section{LIST OF FIGURES}

Figure 1.1: West Coast NGMP monitoring bores; source: Rosen (2001a)................ 6

Figure 1.2: Nitrate-nitrogen $\left(\mathrm{NO}_{3}-\mathrm{N}\right)$ concentrations versus time for all seven

West Coast wells in the NGMP; data source: Rosen, 2001a. 7

Figure 2.1: The West Coast study areas, South Island, New Zealand; Source: James, 2000. 11

Figure 2.2: Grey Valley Geology (study sites marked); Source GNS, 2002 …......... 12

Figure 2.3: Reefton Geology (study sites marked); Source GNS, 2002 ................. 13

Figure 2.4: Kowhitirangi Geology (study sites marked); Source: GNS, 2002 ........... 14

Figure 2.5: Ahaura Valley Soils; source: Landcare Research, 2001 ..................... 15

Figure 2.6: Totara Flat Soils; source: Landcare Research, 2001 .......................... 16

Figure 2.7: Kowhitirangi Soils, source: Landcare Research, $2001 \ldots \ldots \ldots \ldots \ldots \ldots \ldots \ldots \ldots . . .17$

Figure 2.8: Cronadun Soils; source: Landcare Research, $2001 \ldots \ldots \ldots \ldots \ldots \ldots \ldots \ldots \ldots . . . .18$

Figure 2.9: Reefton Soils; source: Landcare Research, 2001............................ 18

Figure 2.10: Mean Monthly Rainfall, Reefton Electronic Weather Station (EWS)

1960 - 2003; source: NIWA, 2003.................................................. 21

Figure 2.11: Mean Monthly Rainfall, Kowhitirangi 1960 - 2003; Source: NIWA,

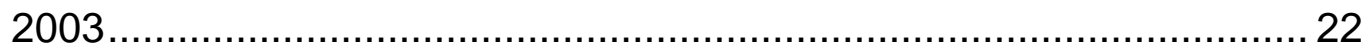

Figure 2.12: Mean monthly rainfall, Waipuna 1982-1999; Source WCRC, 2003. … 23

Figure 2.13: Mean monthly temperatures, Hokitika 1971 - 2001; Source: NIWA, 2002

Figure 2.14: Mean monthly temperatures, Reefton EWS 1960 - 2003; Source:

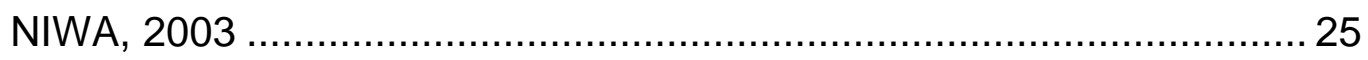

Figure 2.15: Ahaura Valley bores; source: Mapworld Topomap V2.0.61, 2000 ....... 27

Figure 2.16: Totara Flat bores; source: Mapworld Topomap V2.0.61, 2000 ............ 28

Figure 2.17: Kowhitirangi bores; source: Mapworld Topomap V2.0.61, 2000 .......... 29

Figure 2.18: Parkinson bore; source: Mapworld Topomap V2.0.61, 2000 ............... 29

Figure 2.19: Mitchell bore; source: Mapworld Topomap V2.0.61, 2000 ….............. 30

Figure 3-1: Begg Farm Bore \#2 - Totara Flat; Source: Westmere Drilling Ltd, 2002 33

Figure 3-2: Burnett Bore - Totara Flat; Source: Westmere Drilling Ltd, 2002 .......... 34

Figure 3-3: School Bore - Totara Flat; Source: Westmere Drilling Ltd, 2002 35 
Figure 3-4: Mills Bore - Ahaura Valley; Source: Westmere Drilling Ltd, 2002 37

Figure 3-5: Bertacco Bore - Ahaura Valley; Source: Westmere Drilling Ltd, 2002 ... 38

Figure 4.1: West Coast monthly rainfall, 2001; source: NIWA, 2002. 54

Figure 4.2: Long-term monthly rainfall averages, Waipuna (June 1981 to Oct 2003), Kowhitirangi \#2 (Feb 1965 to Apr 2002), Reefton EWS (Aug 1960 to May 2002); source: NIWA (2003), WCRC (2004). .55

Figure 4.3: Nitrate concentrations in the Ahaura Valley, April - September 2001 ....57

Figure 4.4: E.coli occurrences in Ahaura Valley bores.......................................... 59

Figure 4.5: Nitrate concentrations at Totara Flat, April - September 2001.............. 61

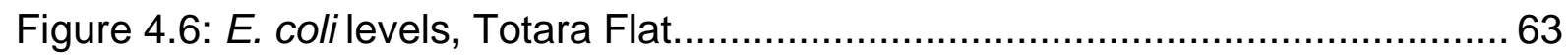

Figure 4.7:Nitrate concentrations, Kowhitirangi. ................................................ 66

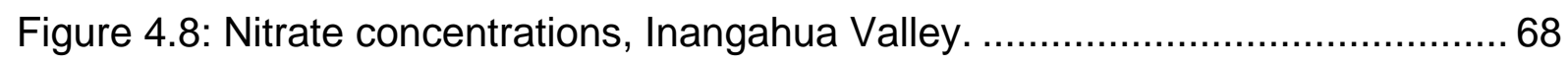

Figure 4.9: Nitrate-N and chloride levels, West Coast Region (each point is the instantaneous value from the four sampling rounds, a total of 76 samples)

Figure 4.10: Variation of nitrate-nitrogen levels with water depth in shallow unconfined bores

Figure 4.11: Variation of nitrate-nitrogen with water level below ground surface in deep unconfined bores ....

Figure 4.12: Nitrate-nitrogen concentration versus bore depth below ground surface (total of 76 samples from all study bores).

Figure 4.13: Nitrate-nitrogen levels of West Coast NGMP bores Sep 1998 - Sep 2003; data: GNS, 2004.

Figure 4.14: Chloride levels of West Coast NGMP bores Sep 1998 - Sep 2003; data: GNS, 2004.

Figure 5.1: CFC concentrations in the atmosphere; source: van der Raaij (2001) ...94

Figure 5.2: Nitrate-nitrogen values in the Bertacco and Mills bores, Ahaura Valley 100

Figure 5.3: Chloride levels in the Bertacco bore, Ahaura Valley. 101

Figure 6.1: Sources and pathways of nitrogen in the subsurface environment; source: modified from Close et al., 2001.

Figure 6.2: NLE data entry screen; Source: Di and Cameron, 2002 ..................... 115

Figure 6.3: OVERSEER data entry screen; Source: AgResearch, 2003. 122 


\section{LIST OF TABLES}

Table 2-1: 2002-2003 West Coast region herd analysis by area. Bracketed values are 2000-2001; Source: LIC, 2001; LIC 2003. 20

Table 3-1: Transmissivities of West Coast bores derived from the Logans and Driscoll methods. 41

Table 4-1: Ministry of Health drinking water guidelines $(\mathrm{MoH}, 2003)$ 51

Table 4-2: Sock water guidelines (ANZECC, 2000) 51

Table 4-3: Recreational water use guidelines (ANZECC, 2000) . 51

Table 4-4: Mean (std dev) ion and nutrient concentrations, Ahaura Valley.

Shaded cells exceed MoH drinking water MAVs/Guidelines (2001) . ...58 58

Table 4-5: Mean (std dev) pH and EC, Ahaura Valley. Shaded cells do not meet $\mathrm{MoH}$ drinking water MAVs/Guidelines (2001).

Table 4-6: Mean (std dev) temperature and dissolved oxygen values, Ahaura Valley.

Table 4-7: Mean (std dev) ion and nutrient concentrations, Totara Flat. Shaded values exceed $\mathrm{MoH}$ drinking water MAVs/Guidelines.

Table 4-8: Mean (std dev) pH and EC, Ahaura Valley. Shaded cells do not meet MoH drinking water standards (2001). 64

Table 4-9: Mean (std dev) temperature and dissolved oxygen, Totara Flat. 65

Table 4-10: Mean (std dev) ion and nutrient concentrations, Kowhitrangi. Shaded cells exceed MoH drinking water MAVs/guidelines (2000).

Table 4-11: Mean (std dev) pH and EC, Ahaura Valley. Shaded cells do not meet $\mathrm{MoH}$ drinking water MAVs/Guidelines (2001).

Table 4-12: Mean (std dev) temperature and dissolved oxygen results, Kowhitirangi. 68

Table 4-13: Mean (std dev) ion and nutrient results, Inangahua Valley. 69

Table 4-14: Mean (std dev) pH and conductivity, Inangahua Valley. Shaded cells do not meet MoH drinking water standards (2001).

Table 4-15: Mean (std dev) temperature and dissolved oxygen results, Inangahua Valley 70

Table 4-16: West Coast NGMP bore trend statistics of nitrate-nitrogen levels (at $95 \%$ confidence interval). 78 
Table 4-17: West Coast NGMP bore trend statistics of Chloride levels

Table 5-1: Nitrogen Isotope and values. $\mathrm{NO}_{3}-\mathrm{N}$ values are average values

calculated over the study period (see Chapter 4 - Water Quality).

Table 5-2: Measured CFC concentrations and derived recommended recharge years

Table 6-1: National Nitrogen Loading Rates; source: after MFE (1999)

Table 6-2: NLE model inputs and results for the Inangahua Valley/Reefton study area

Table 6-3: NLE model inputs and results for the Grey Valley study area 120

Table 6-4: NLE model inputs and results for the Kowhitirangi study area.

Table 6-5: OVERSEER inputs for the Inangahua Valley/Reefton, Grey Valley and Kowhtirangi study areas

Table 6-6: OVERSEER results for the Reefton, Grey Valley and Kowhtirangi study areas (bracketed values are mean observed nitrate-nitrogen concentrations) 


\section{INTRODUCTION}

\subsection{GENERAL INTRODUCTION}

Dairy farming in New Zealand has undergone rapid intensification over the last ten to fifteen years. Nationally, the decrease in the total number of dairy herds and the increase in the average herd size has resulted in the total New Zealand cow population increasing by over 55\% from 2.4 million in 1990/1991 to 3.7 million in 2002/2003, and the national average stocking rate increasing from 2.4 cows/ha in 1990/91 to 2.6 cows/ha in 2002/2003 (LIC, 2003). This intensification has resulted in a greater potential for impacts on groundwater quality, including increased concentrations of nutrients and bacteria in the groundwater, through the leaching of effluent and fertilizers to groundwater (Ledgard et al., 1996).

The rates of intensification in the West Coast region of the South Island have been similar to the national average values. The intensification of dairying in this region has seen the total number of cows increase to over 100,000, the stocking rate increase to $2.03 \mathrm{cows} / \mathrm{ha}$ and the average herd size increase to 269 cows. While only $2.9 \%$ of the New Zealand dairy herds are located in the West Coast region (LIC, 2003), dairying is the West Coast's most productive agricultural activity with a net worth of over $\$ 100$ million (WCRC, 2003).

The potential environmental impact of dairying on groundwater quality is predominantly controlled by the interaction of farm management practices and the physical environment of the individual farm. The physical environment includes the nature and timing of precipitation, the geology and soil characteristics, the topography and the location of water bodies. Different stocking rates, effluent disposal practices, fertiliser application timing and rates are just some of the on farm practices that may influence groundwater quality (EW, 2001). Under the Resource Management Act (1991), it is the role of territorial authorities, in this case the West Coast Regional Council (WCRC), to manage groundwater resources in a manner consistent with the principles of sustainability. 
One of the main environmental effects of dairying that the West Coast Regional Council has to understand and manage is the potential leaching of nutrients and bacteria to groundwater. Of all of the nutrients found in dairy effluent, nitrogen is the most mobile in soils (Ledgard et al., 1996). Most New Zealand soil types are effective in treating bacteria, organic carbon and phosphorus but the treatment of applied nitrogen appears to be limited (Selvarajah, 1996). Disposal of effluent from the dairy shed, along with deposition of urine and dung patches from grazing stock, fertiliser applications and mineralisation of soil organic matter are the main sources of potential leachable nitrogen (MAF, 2000). Consequently, one of the major environmental concerns related to agricultural intensification is the disposal of excess nitrogen, because of the potential for groundwater contamination by nitrate-nitrogen.

Over recent years the WCRC has promoted the application of dairy shed effluent (DSE) onto the land. DSE comes from the cleaning of the dairy shed and associated holding yards on the farm, it is typically a very dilute mixture of water, urine and faeces (Barkle et al., 2000). Until recently, the main method of disposal for DSE has been through 2-stage anaerobic-aerobic treatment ponds that then discharge to surface waters. However the WCRC (like most regional councils in New Zealand) now promotes the application of this DSE through irrigation onto land because of cultural reasons and the desire to protect and maintain surface water quality. While the change in disposal methods may stop the direct contamination of surface waters, the risk of groundwater degradation may have increased. Setting a regional rate at which effluent can be applied to the pasture is a useful tool to help manage the issues involved with DSE disposal. Under the WCRC's Regional Plan for Discharges to Land (2002), the application of DSE to land is a permitted activity providing a number of conditions are met (the main conditions relate to application depths, avoidance of runoff and ponding and not discharging DSE near farm and river boundaries). The WCRC has set the 'application rate from any combination of sludge accumulated from treatment facilities, storage facilities, agricultural effluent, wastewater and whey at a rate not exceeding the equivalent of $275 \mathrm{kgN} / \mathrm{ha} / \mathrm{year}$. This rate is the highest of any of the regional councils in New Zealand.

Associated with the recent intensification of dairying has also been a marked increase in the use of nitrogen fertilisers on New Zealand dairy farms (Di and 
Cameron, 2002). On the West Cost this increase has seen the typical annual nitrogen fertiliser application rate increase to between $100-130 \mathrm{kgN} / \mathrm{ha}$ (LIC, 2003; MAF, 2003). The application of nitrogen to pasture can dramatically increase pasture production; however, when it is applied during wet conditions or in excess quantities it has the potential to cause the leaching of nitrogen to groundwater (Fert Research, 2002; Di and Cameron, 2002; Ledgard et al., 1996; Silva, 1999).

While there are a number of economic, health and environmental concerns over the contamination of groundwater, the principle concern is that of nitrate contamination and its effects on human health and the environment (Selvarajah, 1996). Health effects of elevated levels of nitrate include infantile methaemoglobinaemia and gastrointestinal infections and inflammation (Davies, 2001). Other health issues include contamination by bacteria and pathogens and increased loading of other nutrients and chemicals (Davies, 2001; Ledgard et al., 1996). For water used for human consumption, the Ministry of Health has set out a number of maximum allowable values (MAVs) and guideline values in the New Zealand Drinking Water Standards (2000). Stock water guidelines are much less stringent than drinking water standards, and are administered by the Australian and New Zealand Environment and Conservation council (ANZECC).

To date, studies of groundwater quality, and groundwater resources on the West Coast have been limited and fragmented (James, 2001). No information exists on aquifer properties such as transmissivity and hydraulic conductivity or groundwater ages. However, groundwater quality information has been collected from seven bores that have been monitored by WCRC staff as part of the National Groundwater Monitoring Programme (NGMP) administered by Geological and Nuclear Sciences (GNS). These bores have been monitored quarterly since 1998 and provide a basis for this study (see section 1.3: Groundwater Quality on the West Coast). While results from these bores provide good temporal trend information, their spatial coverage is limited. Expanding the spatial coverage of groundwater quality information, along with the analysis of results from the NGMP bores, will allow an assessment of current groundwater quality to be made and will aid the prediction of future trends. 
Dairying occurs all over the West Coast Region. According to the Livestock Improvement Council (LIC) Dairy Statistics (2003), 34\% of the region's farms occur in the Buller area, 20\% in the Grey area and 46\% in the Westland area. The selection of study bores (see Chapter 2: Study Area) attempted to address this distribution and factors such as whether or not the farm is applying their DSE to land or if the bore is near farms applying their DSE to land. Where possible, groups of bores situated along a groundwater gradient were chosen to investigate the potential movement of contaminants through the aquifer.

In addition to groundwater quality data, information on the age of the groundwater has been used in many studies to help put any present contamination into context (for example: Dunkle et al., 1993; Plummer and Bunsenberg, 2000; van der Raaij, 2000). Using Chloroflurocarbon (CFC) dating on water from a selection of bores the age of the groundwater, and therefore the age of any contamination, was obtained. As well as determining the timing of any contamination, determining the source of contaminants is important. As identified above, nitrate-nitrogen has several potential sources. The use of nitrogen isotope analysis has been used in a number of studies (Bohlke and Denver, 1995; McLarin et al., 1999; van der Raaij, 2000; Kellman and Hillaire-Marcel, 2002) to determine whether the nitrogen source is effluent (either human or animal), fertiliser or derived from soil organic matter. Thus nitrogen isotope analysis was conducted on samples from a number of bores sampled in this study.

With analysis of data from the NGMP and study bores, age dating information, and nitrogen isotope analysis, a good picture of the state of the West Coast region's groundwater will be presented. Analysing the state of the groundwater resources, in light of the current dairy farm management practices, will aid an assessment of the viability and sustainability of current land management policies.

To help improve the management of the West Coast groundwater resource and to aid future policy decisions, the determination of accurate nutrient budgets is essential. Nutrient budgets allow the determination of nitrogen application rates that are suitable and sustainable at both the farm and regional scale (Agresearch, 2002; Di and Cameron, 2002). The OVERSEER nutrient budget model (Ledgard et al., 1999, 2001) was developed to estimate nutrient balances for pastoral and cropping 
systems. It has traditionally been used to identify situations of nutrient excess or deficit at the individual farm block scale; however, the results from individual farms can be combined to give results at a catchment and regional scale (MAF, 2002). The Nitrogen Leaching Estimation (NLE) model is a semi-empirical model for estimating nitrogen leaching losses and critical nitrogen application rates in dairy pasture systems (Di and Cameron, 2002). Using both of these models, both leaching rates, and sustainable application rates of nitrate-nitrogen can be determined and compared with existing measured values.

\subsection{GROUNDWATER QUALITY DATA PRIOR TO 2001}

Groundwater quality within the West Coast region has been monitored as part of National Groundwater Monitoring programme (NGMP) since 1998. The results from the early part of this programme (1998-2000) were one of the reasons for this study. Historically high rainfall and the subsequent abundance of surface water has limited groundwater use on the West Coast (James, 2001). However, with the intensification and expansion of the dairying industry, more pressure has been placed on the region's water resources. Concurrently, a more general need for groundwater monitoring has become apparent over much of New Zealand.

In total seven bores are monitored by the WCRC as part of the National Groundwater Monitoring Programme (NGMP; Figure 1.1). Five of the seven bores are located on dairy farms, one is in an urban environment (Waterworld) and one in a rural residential area (Milne). The bores are monitored to help determine the effects of various landuses on groundwater quality and to determine trends in groundwater quality in the region (James, 2001). Full results from the NGMP are listed in Appendix 3. 


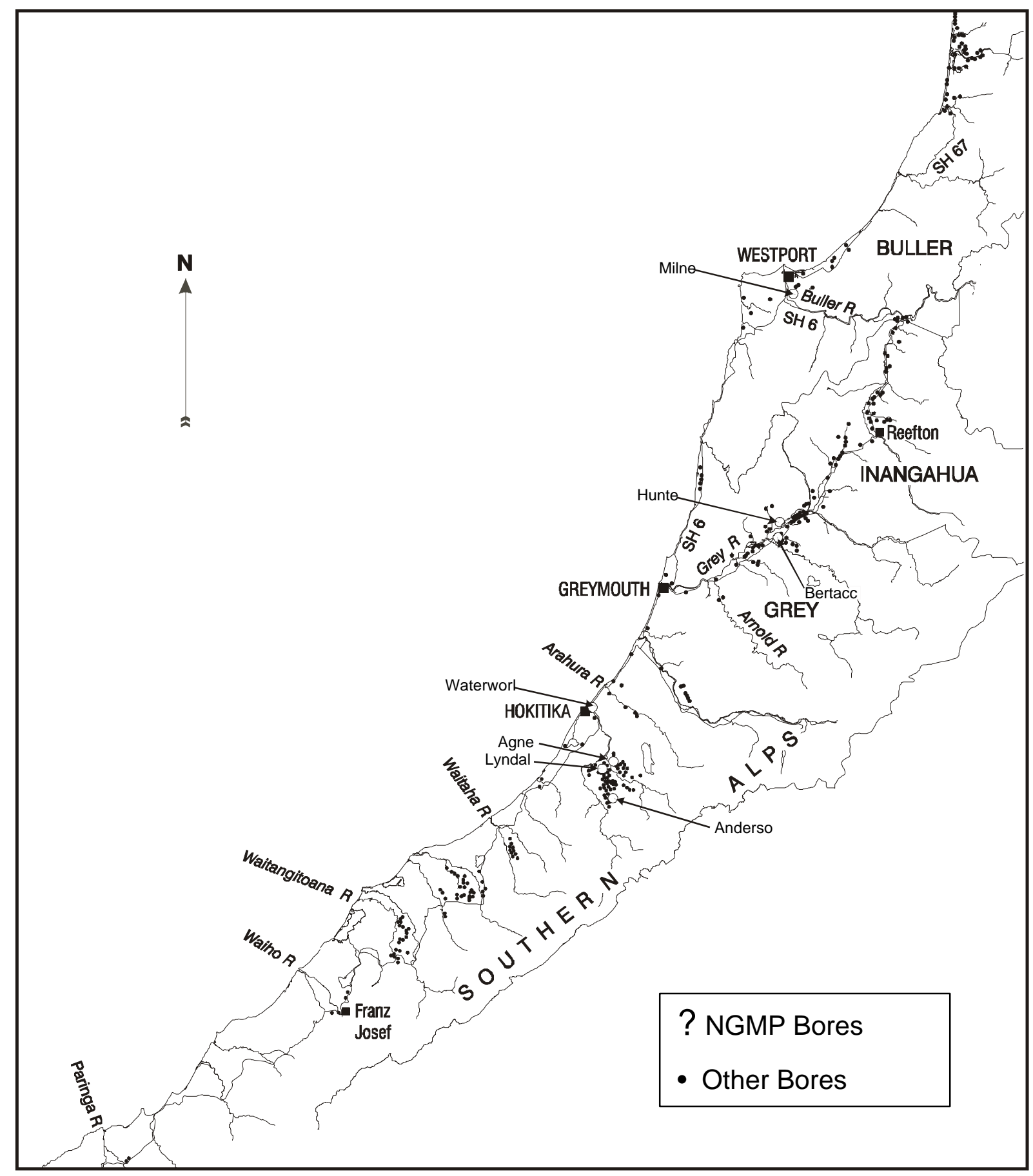

Figure 1.1: West Coast NGMP monitoring bores; source: Rosen (2001a)

Results from the first two years of sampling showed increasing concentrations of nitrate-nitrogen $\left(\mathrm{NO}_{3}-\mathrm{N}\right)$ in five of the seven NGMP bores while the Milne bore showed an increasing trend from the second sampling round (Rosen, 2001a; Figure 1.2). The only bore not to show an increasing trend in nitrate nitrogen (Waterworld) was not located near a dairy farm. The bores which showed increasing 
concentrations of nitrate-nitrogen were all associated with dairy farms and it is likely that this landuse has contributed significantly to nitrogen inputs in the groundwater systems associated with these bores (Rosen, 2001a).

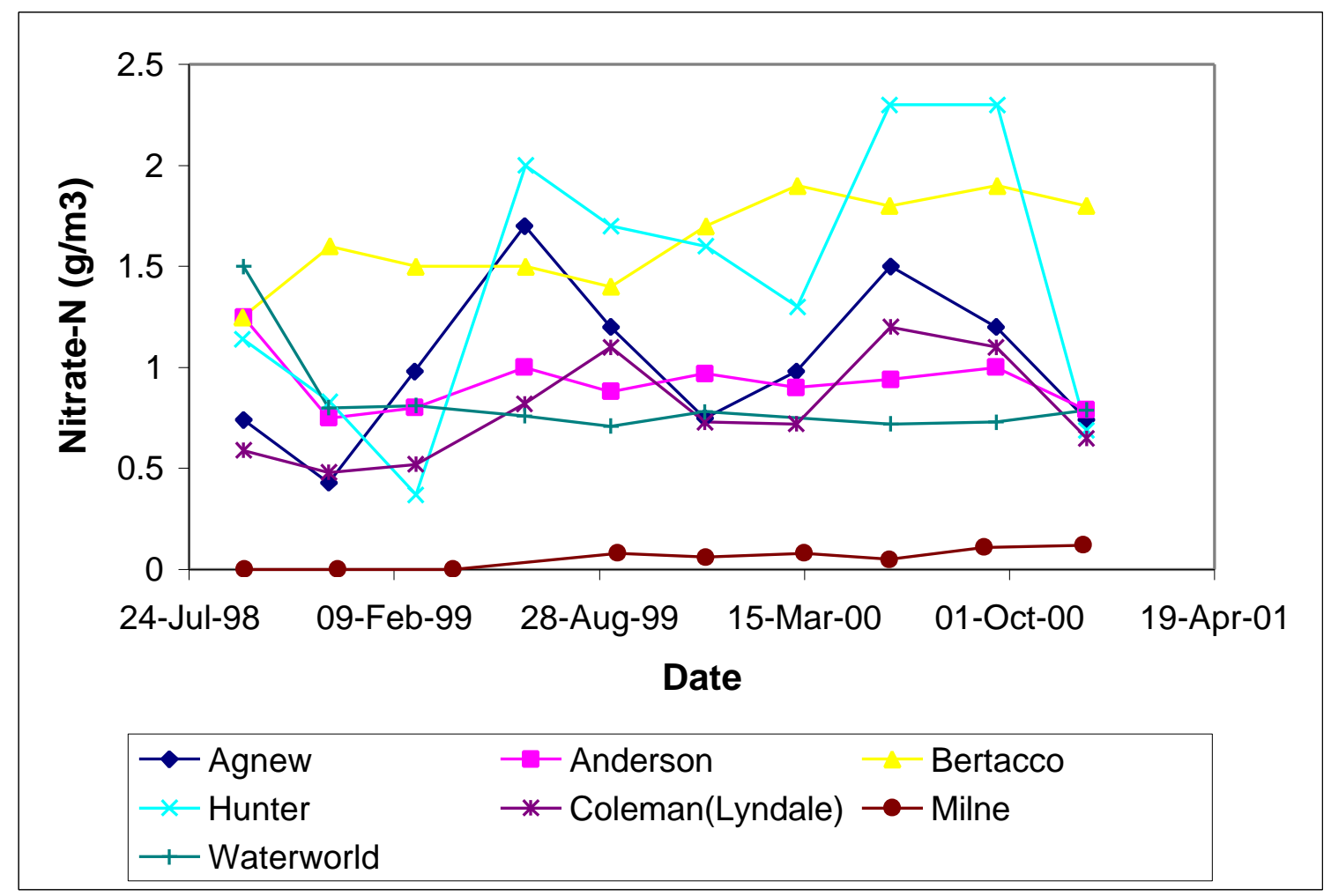

Figure 1.2: Nitrate-nitrogen $\left(\mathrm{NO}_{3}-\mathrm{N}\right)$ concentrations versus time for all seven West Coast wells in the NGMP; data source: Rosen, $2001 a$.

Some seasonal variation in nitrate-nitrogen concentrations is evident in the Coleman (Lyndale) bore although all of the bores show increases in nitrate-nitrogen since 1998. Six of the seven bores show levels of nitrate-nitrogen that are possibly elevated due to anthropogenic influences. These increases in nitrate-nitrogen levels warrant further examination (Figure 1.2). Sulphate concentrations have been increasing in the Bertacco bore, which showed increasing nitrate-nitrogen, suggesting the possibility that fertiliser use is impacting on shallow groundwater in some areas (Rosen, 2001a).

Iron and Manganese concentrations exceeded the maximum acceptable value for drinking water in New Zealand in the Agnew, Hunter and Milne bores on some occasions. Rosen (2001a) suggests the manganese exceedences should be viewed 
with caution due to poor ion balances and low median concentrations, and the Iron exceedences are likely a result of naturally low reduction-oxidation (redox) conditions.

Following a review of the first two years of data, Rosen (2001a) suggested that the increasing trends of nitrate-nitrogen in these bores warranted further investigation. While the data from the seven groundwater sites monitored as part of the NGMP provide a context and a useful time series they cover a very limited spatial area. This study expands on that spatial extent and examines the links between groundwater and landuse.

\subsection{PROJECT AIMS}

Given the discussion above, the main objectives of this study were to:

1. Examine the effects of land-based application of DSE on the groundwater quality of the West Coast region

2. Expand on the current knowledge of West Coast groundwater resources through:

- the testing and analysis of groundwater quality in a greater spatial spread of bores,

- summarising the hydrogeological characteristics of the main West Coast shallow unconfined aquifers

3. Determine the age of the groundwater of selected West Coast aquifers

4. Determine the source of observed nitrate-nitrogen contamination through the use of nitrogen isotope analysis

5. Provide the WCRC information on which to base planned expansions to their groundwater quality monitoring programme

6. Determine, through a nutrient balance approach, a sustainable nitrogen loading rate for the West Coast region

The range of results from this study will add to the currently limited information on West Coast groundwater resources. Analysis of current patterns and prediction of future trends will help aid future management and policy decisions that the WCRC 
may have to make to manage the quality of groundwater in the region. The determination of a new nutrient balance based nitrogen application rate for the region will be of use in any future revisions to the Regional Plan for Discharge to Land (2002) as the current rate was not based on this approach.

This thesis comprises seven chapters including this introductory chapter and a summary and recommendations chapter. The physical and climatic characteristics of the study area, along with the location of the study sites are described in chapter two. Chapter three summarises the hydrogeology of the region and includes the calculation of transmissivities and hydraulic conductivities for the aquifers studied, which are needed to understand contaminant flow rates and aquifer characteristics. Chapter four, the groundwater quality chapter, focuses on the first and second project aims by outlining the methodologies used for the groundwater quality sampling, reporting and analysing the results from both the study bores and the NGMP bores. Chapter five focuses on the third and fourth project aims through the use of CFC dating and nitrogen isotope analysis. Chapter six builds on the results from chapters two, three and four and describes the issues of nitrate leaching, and using two models, assesses the current nitrogen loading rates. Finally, chapter seven summarises the finding from the thesis and offers some recommendations for both future work and resource managers. 


\section{STUDY AREA}

The West Coast region is New Zealand's third largest territorial area by land area. It is bounded in the east by the Southern Alps and in the west by the Tasman Sea and has a land area of 23,000 square kilometres, or $8.5 \%$ of New Zealand's land area (WCRC, 2003).

The economy of the West Coast is highly dependent on land-based activities. Pastoral farming is the second largest industry on the West Coast behind tourism bringing in an income to the region of over $\$ 100$ million per year (WCRC, 2003). Dairying is the main contributor to the pastoral farming industry and continues to grow annually (LIC, 2003). While dairying occurs over the whole of the region, the majority of farms are centered around the Grey Valley and Kowhitirangi areas.

\subsection{PHYSICAL SETTING}

The West Coast of New Zealand's South Island is climatically and physically different from the rest of New Zealand, because of its position relative to the unbroken mountain chain of the Southern Alps. No other region in New Zealand has the combination of:

- a narrow coastal fringe backed by high mountains, which were extensively glaciated during the late Quaternary period;

- very high annual rainfall yet mild lowland temperatures;

- wet, leached soils and indigenous forest (Molloy, 1998); and,

- large alluvial outwash terraces with substantial groundwater resources.

This study focuses on three areas of the West Coast, the Grey Valley; Kowhitirangi; and the Inangahua Valley/Reefton area (Figure 2.1) through the study of twenty-two groundwater bores. Nineteen bores were sampled between January - December 2001 especially for this study while three bores sampled by the West Coast Regional Council, as part of their contribution to the National Groundwater Monitoring 
programme, are also included. Prior to discussion of the bore locations and characteristics, landuse, climate, geology and soils of the region will be described.



Figure 2.1: The West Coast study areas, South Island, New Zealand; Source: James, 2000. 


\subsection{GEOLOGY}

Much of the Grey and Inangahua valleys and the low lying land around the Kowhitirangi area, to the south, have a complex cover of late Quaternary moraine, river and alluvial fan gravel, coastal and lagoon deposits and swamps (GNS, 2002).

Extensive sequences of river terraces occupy about one-third of the Grey (Figure 2.2) and Inangahua valleys (Figure 2.3). The most widespread are the highest terraces (older than 22000 years; remnants of former glacial outwash terraces) and the low glacial outwash terraces (14 000 to 22000 years old; remnants of later glacial outwash surfaces) (Molloy, 1998).

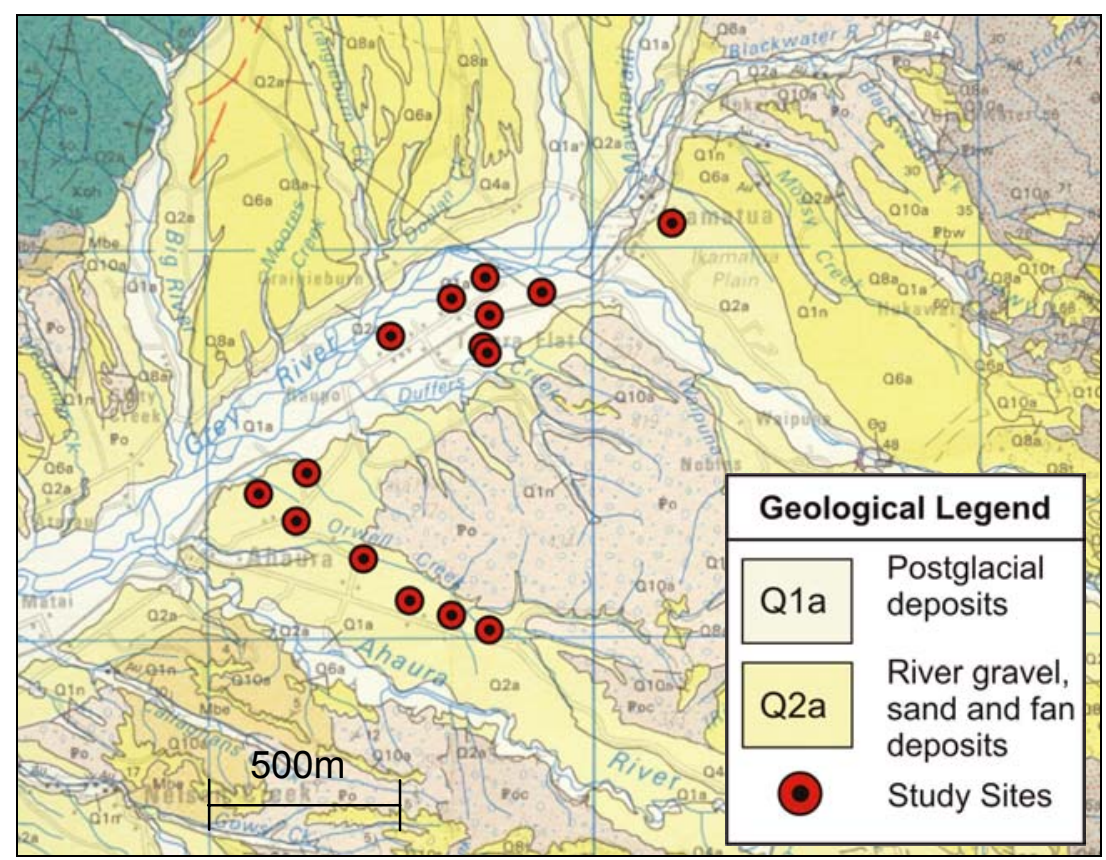

Figure 2.2: Grey Valley geology (study sites marked); Source GNS, 2002 


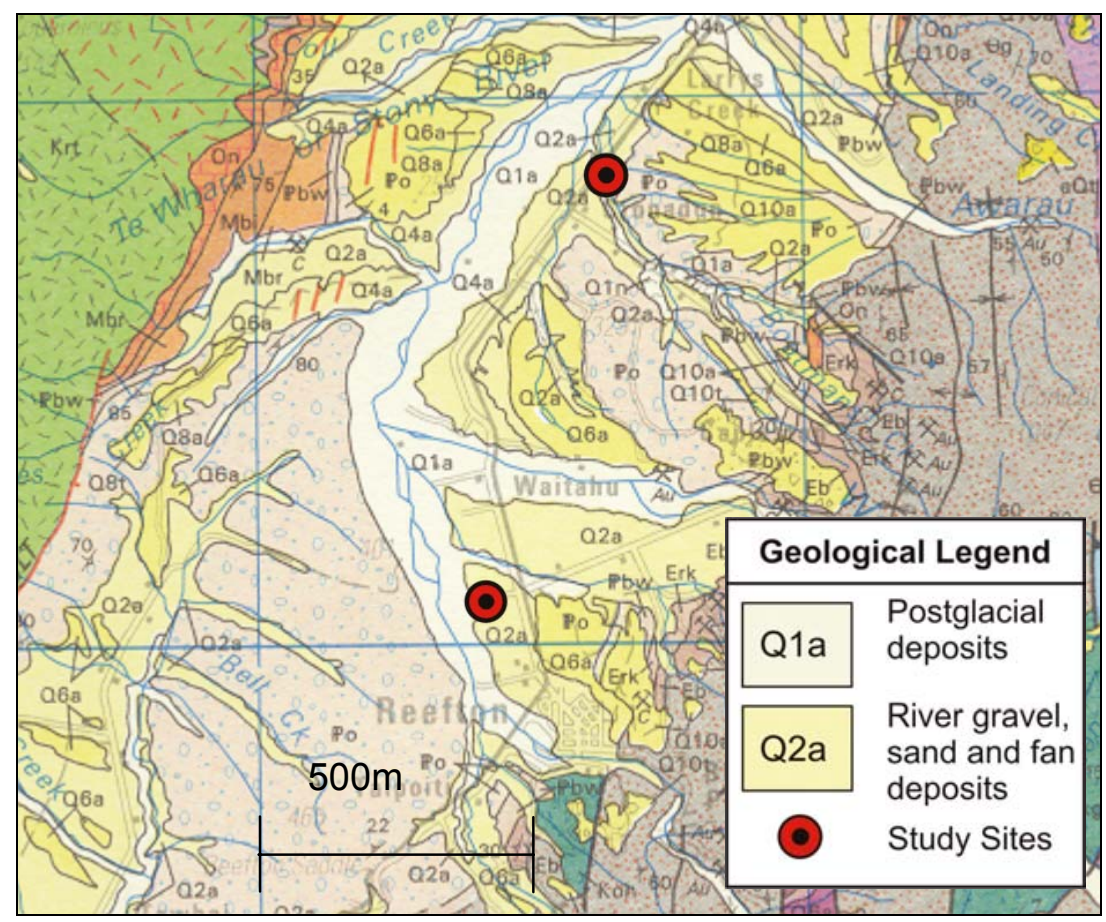

Figure 2.3: Reefton Geology (study sites marked); Source GNS, 2002

These terraces are underlain by alluvial and fluvioglacial gravels typically consisting of poorly sorted pebble to boulder size clasts in a sandy matrix (GNS, 2002). In all three study areas these gravels can be classified into 2 distinct units: Q1a consists of postglacial deposits, including river gravel and sand, fan deposits and swamp deposits; and, Q2a, which are older deposits ranging from 15 - 24,000 years consisting of river gravel, sand and fan deposits.

The Kowhitirangi sites are underlain by postglacial deposits, Q1a (Figure 2.4), and are situated on a low lying floodplain between the Hokitika and Kokatahi rivers. 


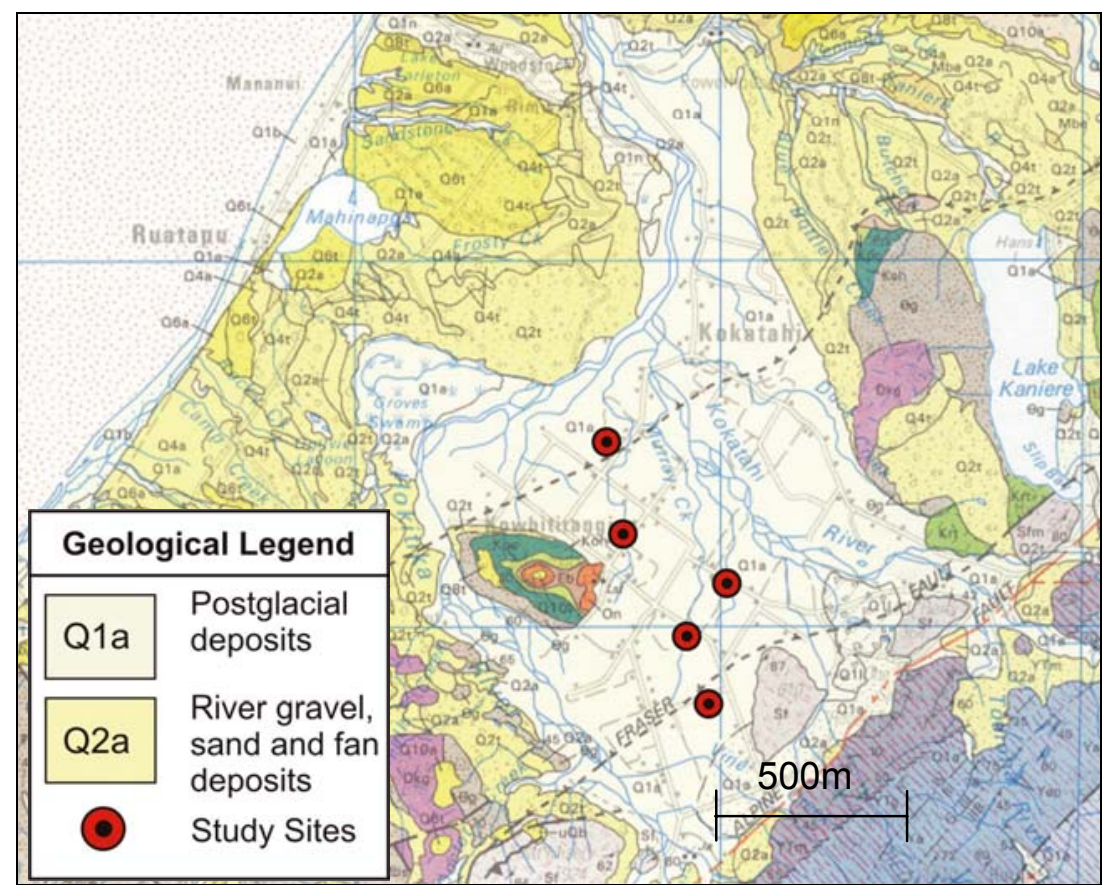

Figure 2.4: Kowhitirangi Geology (study sites marked); Source: GNS, 2002

\subsection{SOILS}

Understanding the physical and chemical characteristics of soils are important in groundwater quality studies because the soil acts as a filter and a buffer to contaminants entering the groundwater system. Soil physical properties, such as porosity and texture, affect drainage and water movement; hence, the nature and timing of potential groundwater and chemical inputs. The soil's chemical properties affect nutrient leaching and plant uptake of nutrients.

\subsubsection{Grey Valley}

In the Ahaura area of the Grey Valley the dominant soil type is the Ahaura series, which cover approximately 15,000 ha of low glacial outwash terraces in both the Inangahua and Grey Valleys (Molloy, 1998). Ahaura soils are well drained with moderately thick $(20-25 \mathrm{~cm})$ dark brown silt loam topsoil over a yellowish-brown stony silt loam subsoil. The soil's structure is weak and consistence is friable. Gravel and silt lenses are found at approximately $1 \mathrm{~m}$ depth, indicating an alluvial origin of the soils. The soils are generally acidic, have a low nutrient status and a high capacity for the retention of phosphate in their subsoils (Molloy, 1998). The A-horizons of the soils are acidic, and medium in total carbon and nitrogen content; however, these 
decrease with depth to very low levels at $50 \mathrm{~cm}$. Nonetheless, the Ahaura soils offer the best prospects for pastoral farming out of all of the soils on the West Coast (Mew, 1980).

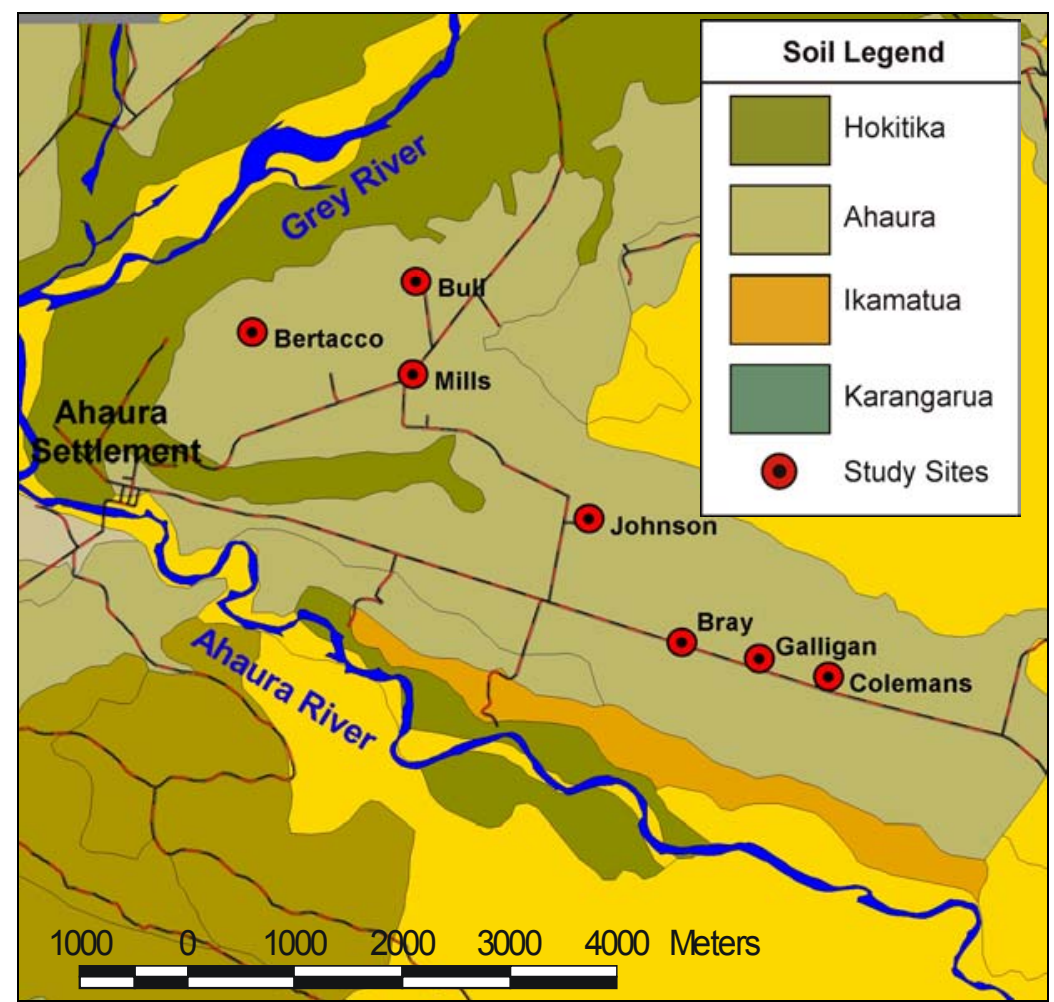

Figure 2.5: Ahaura Valley Soils; source: Landcare Research, 2001

The Hokitika series is found on the low lying river flats of the Totara Flat area (Figure 2.6) and the Kowhitirangi area (Figure 2.7). It is developed in alluvium and is normally a sandy loam to loamy sand, frequently with stones or boulders in the profile. It has a shallow A-horizon averaging 18cm (Mew, 1980). The Hokitika soils are well drained soils with moderately rapid permeability. As a relatively unweathered soil the Hokitika series has high reserves of nutrients such as phosphorus, potassium and magnesium. 


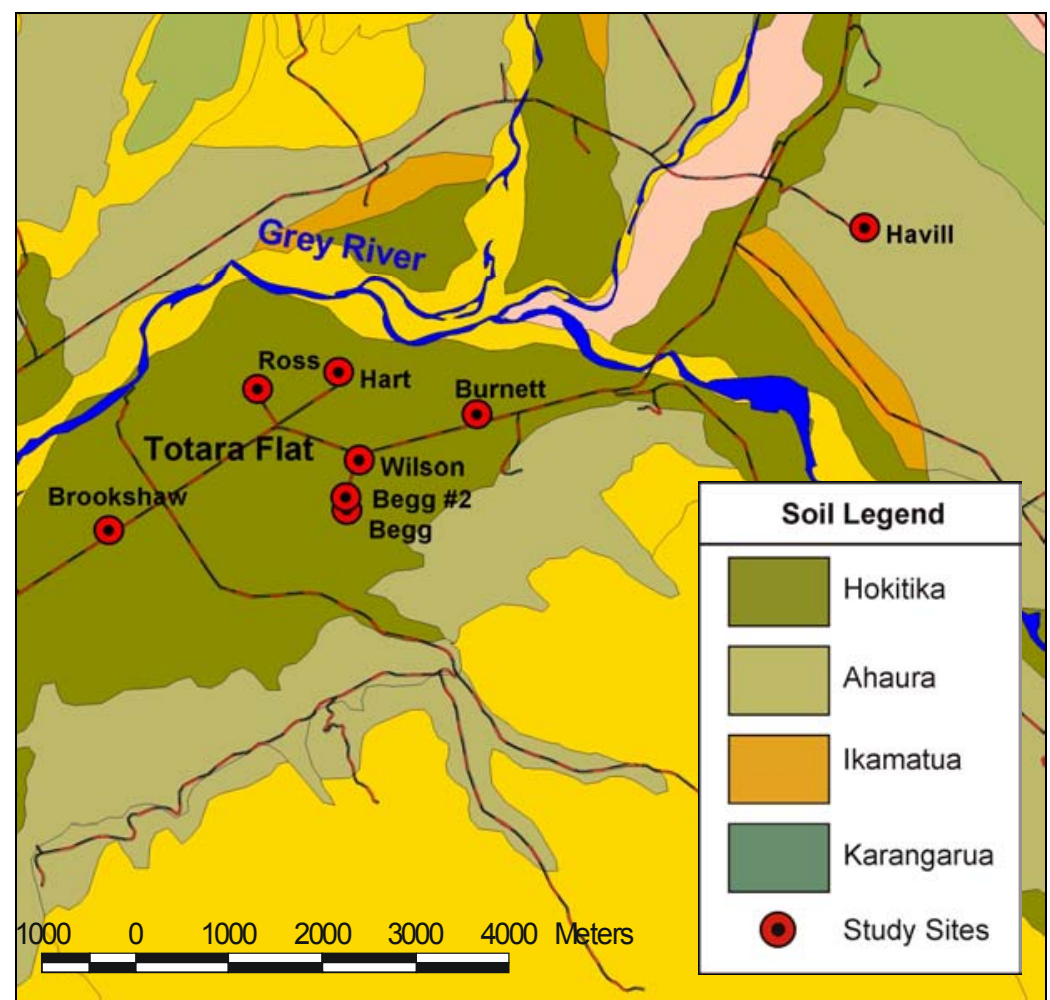

Figure 2.6: Totara Flat Soils; source: Landcare Research, 2001

\subsubsection{Kowhitirangi}

In addition to the Hokitika series, the Karangarua series is widespread in the Kowhitirangi area (Figure 2.7). In its original state, the Karangarua series is a strongly gleyed soil with poor permeability and poor drainage (Mew, 1980). It occurs mainly in areas with a high water table but it is rarely flooded. The areas where this soil occurs have been extensively drained to help reduce the winter water content. Often the 'humping and hollowing' technique is used to improve drainage of these soils. The natural nutrient status of these soils is low; however, they do respond well to fertilizer applications (Mew, 1980). 


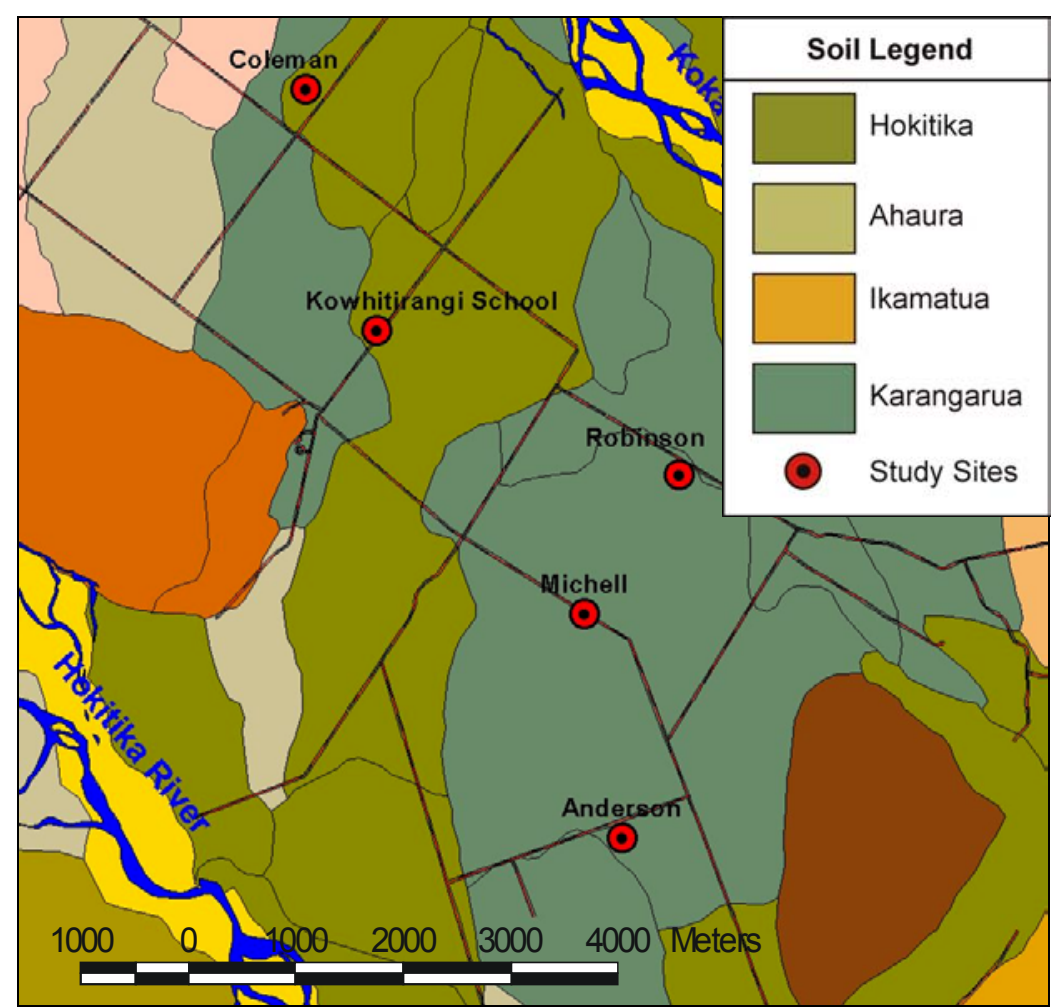

Figure 2.7: Kowhitirangi Soils, source: Landcare Research, 2001

\subsubsection{Inangahua Valley}

Occuring only at the Inangahua valley sites (Figure 2.8, Figure 2.9), is the Ikamatua series. The Ikamatua series are lowland yellow-brown soils, occurring on the low terraces along major rivers and on some low angled fans.

The Ikamatua series is well drained, with moderate permeability (Mew, 1980). The soils have a medium to low fertility; however, they have good potential for pastoral farming. 


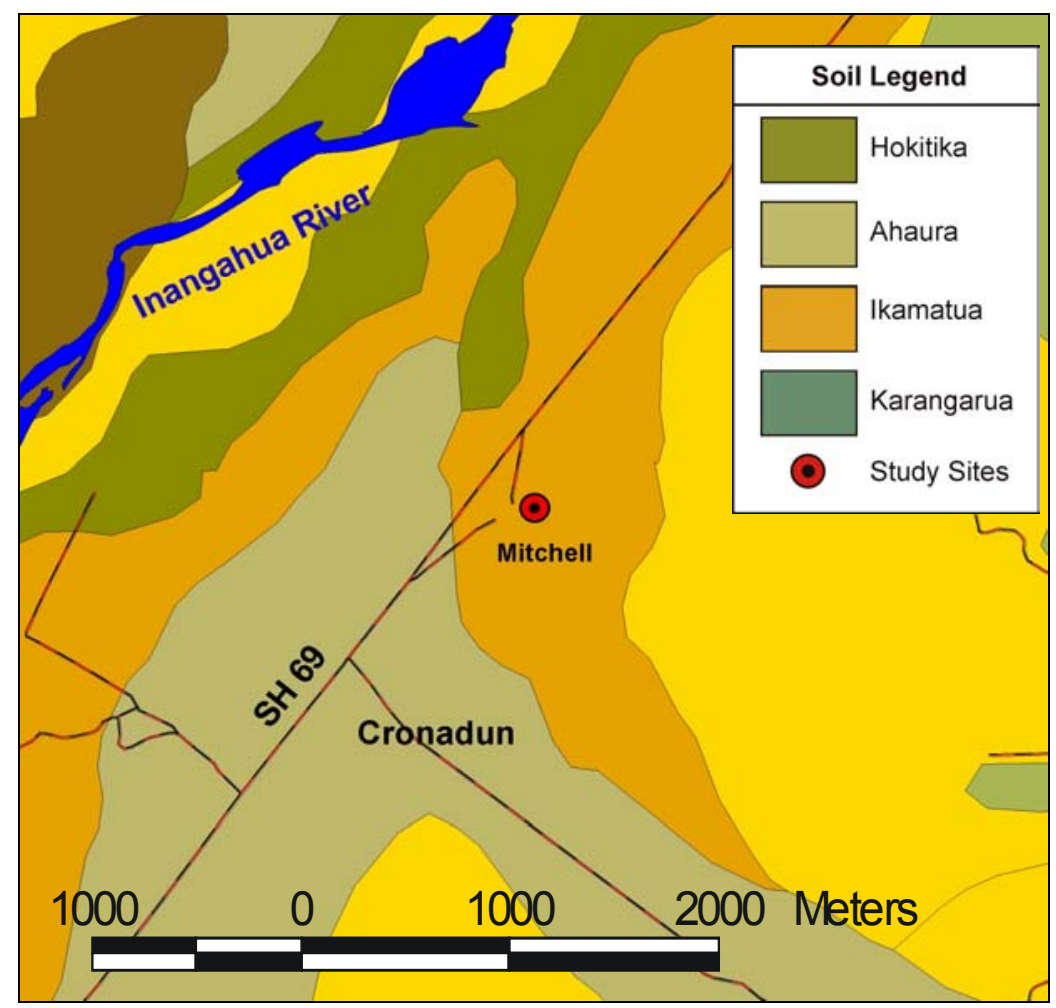

Figure 2.8: Cronadun Soils; source: Landcare Research, 2001

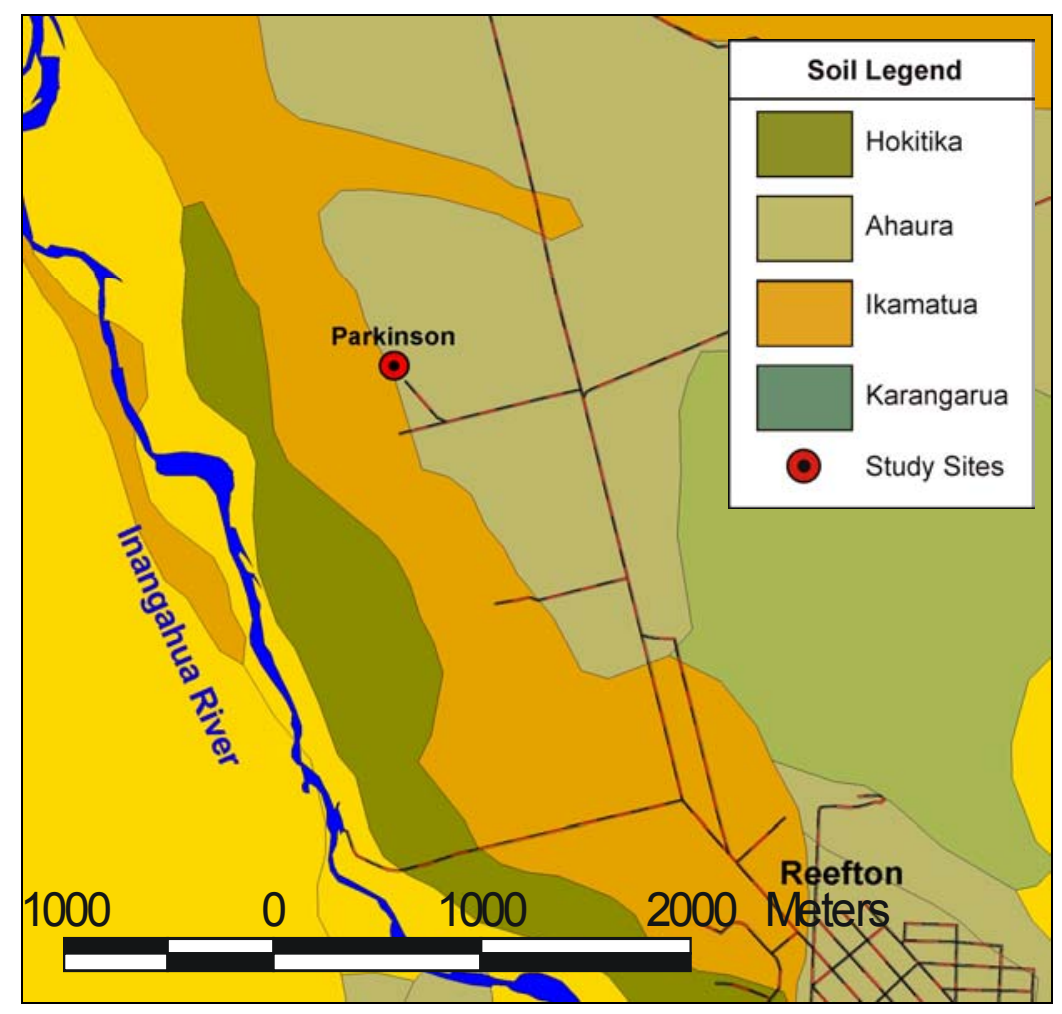

Figure 2.9: Reefton Soils; source: Landcare Research, 2001 


\subsection{LANDUSE}

\subsubsection{Past Landuse}

Until the late $19^{\text {th }}$ century most of the river terraces and plains of the Grey Valley and Hokitika areas were covered in dense rimu, kamahi and totara forest. Towards the end of the century settlers began to clear extensive tracts of this lowland vegetation for agricultural purposes. This deforestation has continued in these areas until as recently as the 1990s. Early farming consisted of mainly sheep and cattle; however, since the 1940s dairy farming has increased (Mitchell pers. comm., 2001).

\subsubsection{Current land use}

On the lower terraces of the Grey Valley and over the Kowhitirangi flats dairy farming is the predominant land use. The upper terraces of the Grey Valley are covered in a mix of regenerating native forest, pristine native forest and exotic forestry plantations (Mew, 1980).

The West Coast, like much of New Zealand, has seen a growth in dairying in the past decade (MAF, 2001). This growth, mainly through landuse intensification and farm conversions, has seen an increase in both farm size and stock numbers. However, as a result of these recent conversions most land suitable for dairying is now carrying cows (MAF, 2001) and the number of dairying conversions has dropped significantly.

There were a total of 365 herds in the West Coast Region during the 2000/2001 season with an average herd size of 244 cows (Table 2-1). This is just below the national average of 251 cows per herd (LIC, 2001). This increased to a total of 375 herds and an average herd size of 269 cows by the end of the 2002/2003 season (LIC, 2003) indicating the decline in the rate of increase of dairying conversions on the West Coast. 


\begin{tabular}{l|l|c|c|c|c}
\multicolumn{1}{c|}{ Area } & $\begin{array}{c}\text { Total } \\
\text { herds }\end{array}$ & \multicolumn{1}{|c|}{ Total cows } & $\begin{array}{c}\text { Average } \\
\text { herd size }\end{array}$ & $\begin{array}{c}\text { Average } \\
\text { effective } \\
\text { hectares }\end{array}$ & $\begin{array}{c}\text { Average } \\
\text { cows per } \\
\text { hectare }\end{array}$ \\
\hline Buller & $134(126)$ & $35,677(30,744)$ & $266(244)$ & $125(109)$ & $2.2(2.18)$ \\
\hline Grey & $78(71)$ & $25,857(20,974)$ & $332(295)$ & $169(150)$ & $2.03(2.0)$ \\
\hline Westland & $163(168)$ & $39,235(37,398)$ & $241(223)$ & $135(125)$ & $1.89(1.9)$
\end{tabular}

Table 2-1: 2002-2003 West Coast region herd analysis by area. Bracketed values are 2000-2001; Source: LIC, 2001; LIC 2003.

Increases in the total number of cows, herd size, average effective hectares farmed and the stocking rate were all seen over the period 2000-2003 (Table 2-1). The stocking rate, or average cows per hectare did not increase to the same degree as the increase in total cow numbers due to the increase in farm size, or average effective hectares farmed.

\subsection{CLIMATE}

\subsubsection{Rainfall}

Rainfall is one of the main factors influencing groundwater quality. As the agent for the transport of potential contaminants into the groundwater system, knowledge on both the volume and timing of rainfall over the study area is very important (Thorpe, 2001).

By both national and international standards the West Coast region receives generous and reliable rainfall. Near the Main Divide rainfall exceeds $8000 \mathrm{~mm}$ annually, while the majority of the coastal strip receives between 2000 and $4000 \mathrm{~mm}$ of rainfall annually. Because the study areas of the Grey and Inangahua valleys lie inland (in the rain-shadow of the Paparoa range) they have a slightly lower rainfall ( $2000 \mathrm{~mm})$ and are more susceptible to winter frosts and fogs (Molloy, 1998).

At the study locations total average annual rainfall varies from $1988 \mathrm{~mm}$ to $3496 \mathrm{~mm}$. That is, average annual rainfall in the Grey Valley, measured at Waipuna, is $1996 \mathrm{~mm}$ (1982 - 1999). Average annual rainfall in Kowhitirangi (Kowhitirangi Station \#2) is 
$3496 \mathrm{~mm}(1970-1999)$ and at Reefton average annual rainfall is $1988 \mathrm{~mm}(1960-$ 2003).

In addition to total annual average rainfall, the mean monthly rainfall at the study sites is also variable. Mean monthly rainfall at Reefton (Figure 2.10) is reasonably consistent with a mean monthly rainfall of $165 \mathrm{~mm}$ (std. dev $=28 \mathrm{~mm}$ ). The wettest month is usually October with $196 \mathrm{~mm}$ and the driest is February with $105 \mathrm{~mm}$.

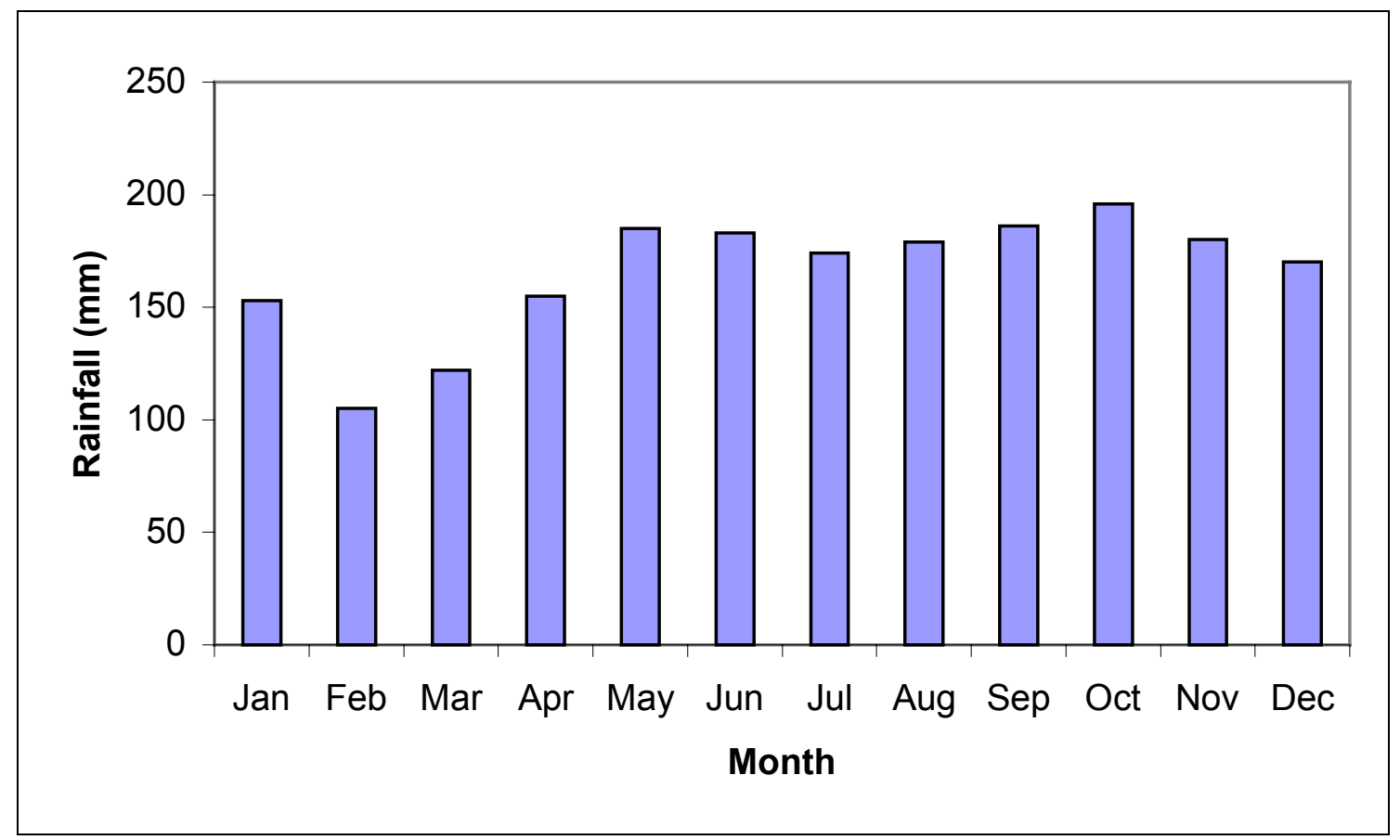

Figure 2.10: Mean Monthly Rainfall, Reefton Electronic Weather Station (EWS) 1960 - 2003; source: NIWA, 2003.

Long-term mean monthly rainfall figures for the Kowhitirangi \#2 site show that rainfall in this area is greater than in the Grey and Inangahua valleys. Monthly means range from $361 \mathrm{~mm}$ in October to $227 \mathrm{~mm}$ in February (Figure 2.11). The mean monthly rainfall is $291 \mathrm{~mm}$ (std. dev. $42 \mathrm{~mm}$ ). 


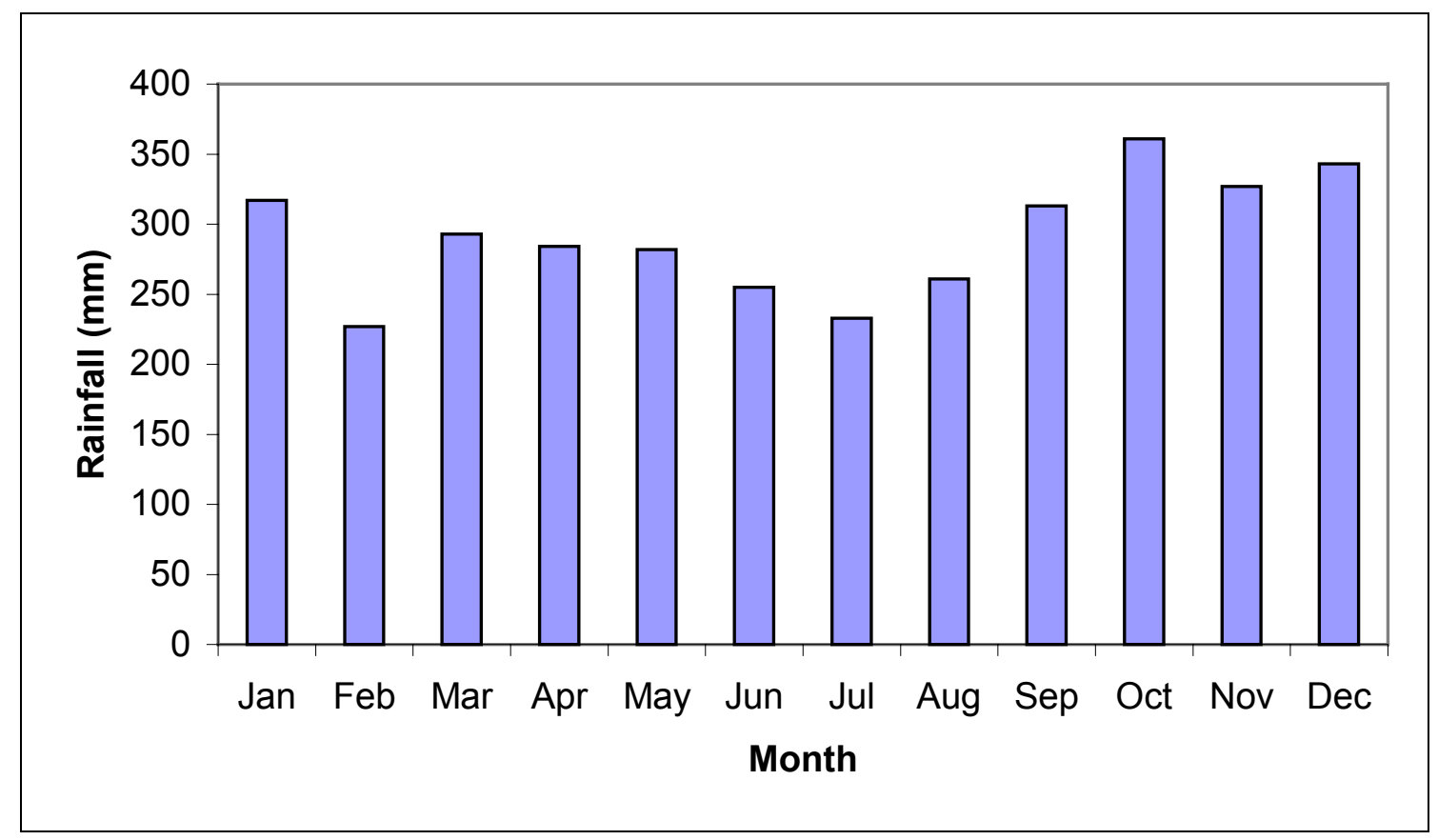

Figure 2.11: Mean Monthly Rainfall, Kowhitirangi 1960 - 2003; Source: NIWA, 2003

Figure 2.12 shows the long term mean monthly rainfall for the Grey Valley, measured at the Waipuna site. At this location months with the greatest rainfall are fairly evenly spread from winter to early summer (May-December). While the average annual rainfall total is very similar to the Reefton sites (Figure 2.10), the monthly distribution of rainfall is much more even. 


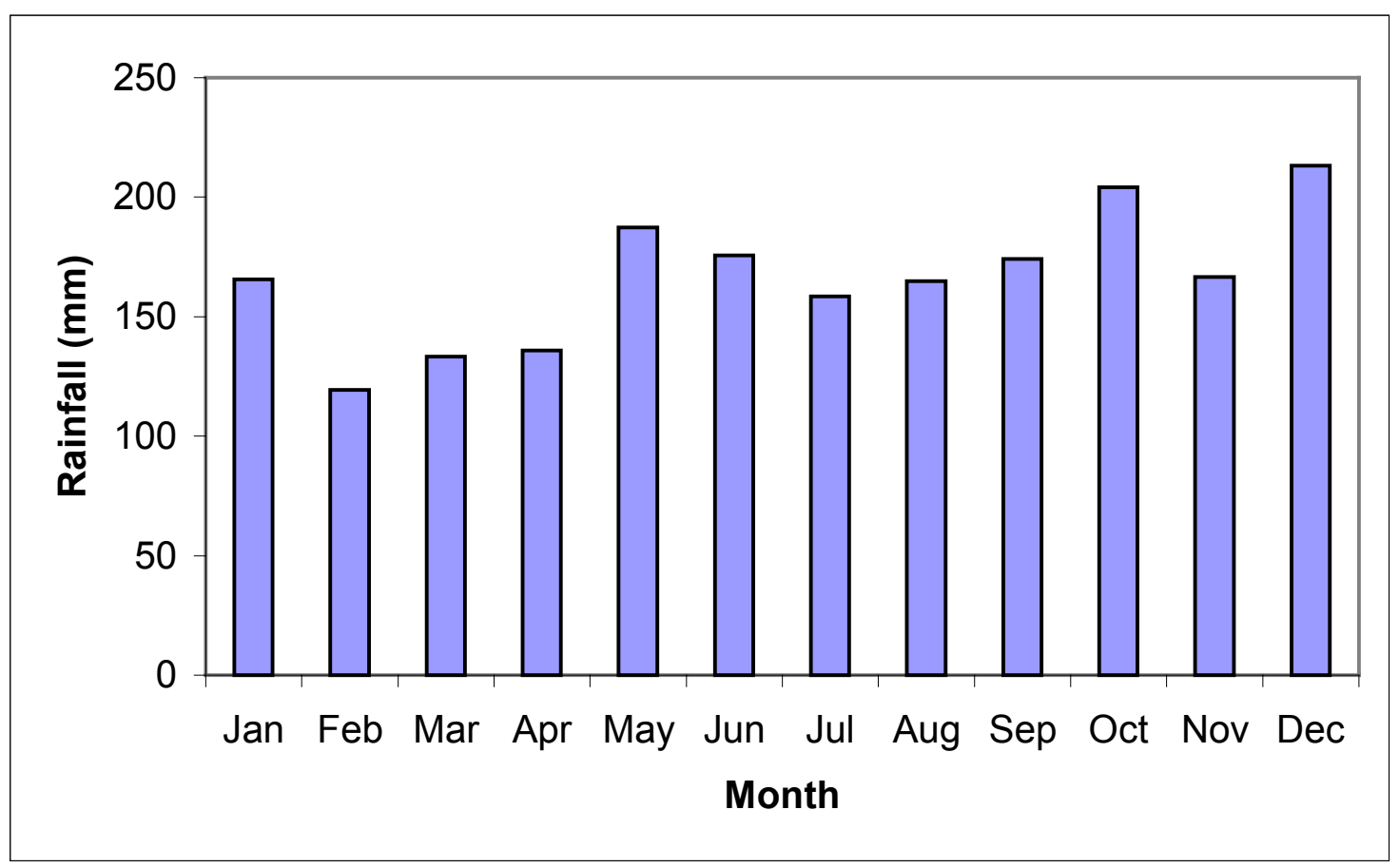

Figure 2.12: Mean monthly rainfall, Waipuna 1982-1999; Source WCRC, 2003.

\subsubsection{Temperature}

Air and soil temperatures influence physical, chemical and biological reactions in soil and plant growth (Mew, 1980). These are all important factors in controlling the movement of chemicals and nutrients through the soil and into the groundwater system. Cool air temperatures result in lower soil temperatures and decreased plant growth. With a decrease in plant growth and therefore nutrient uptake, there is an increased risk of nutrient leaching into shallow groundwater, especially when infiltration rates are high.

No temperature records are available for the Grey Valley, so temperature statistics are taken from the Reefton EWS site, and the climate station at Hokitika Airport. The average monthly temperature in Hokitika, measured at the Airport for 1971-2000, is $12.6^{\circ} \mathrm{C}$ (Figure 2.13). Instantaneous air temperatures ranged from $30.0^{\circ} \mathrm{C}$ to $-3.4^{\circ} \mathrm{C}$ and there is an average of 54 days of ground frosts annually (NIWA, 2002). 


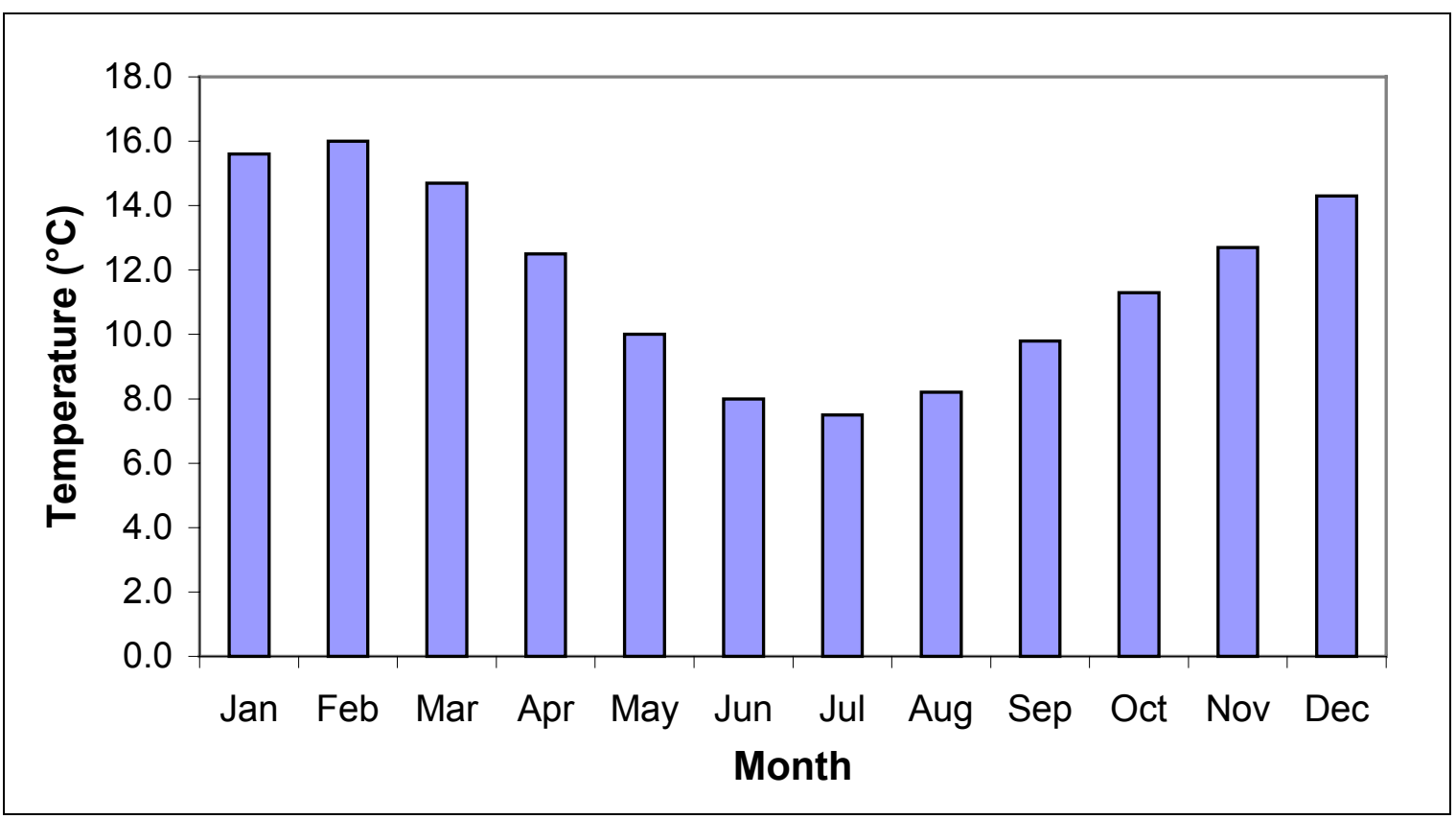

Figure 2.13: Mean monthly temperatures, Hokitika 1971 - 2001; Source: NIWA, 2002

Further inland, away from the moderating influence of the sea, temperature extremes are greater and frosts more regular. Mean monthly air temperatures measured at the Reefton EWS site (Grid reference L30 156 984) show higher monthly averages in summer and cooler temperature during the winter months (Figure 2.14.). The mean monthly temperature at the Reefton EWS is $11.2^{\circ} \mathrm{C}$. The Grey Valley would show similar temerature patterns to the Reefton data; however, no actual temperature data was available for the Grey Valley at the time of writing. 


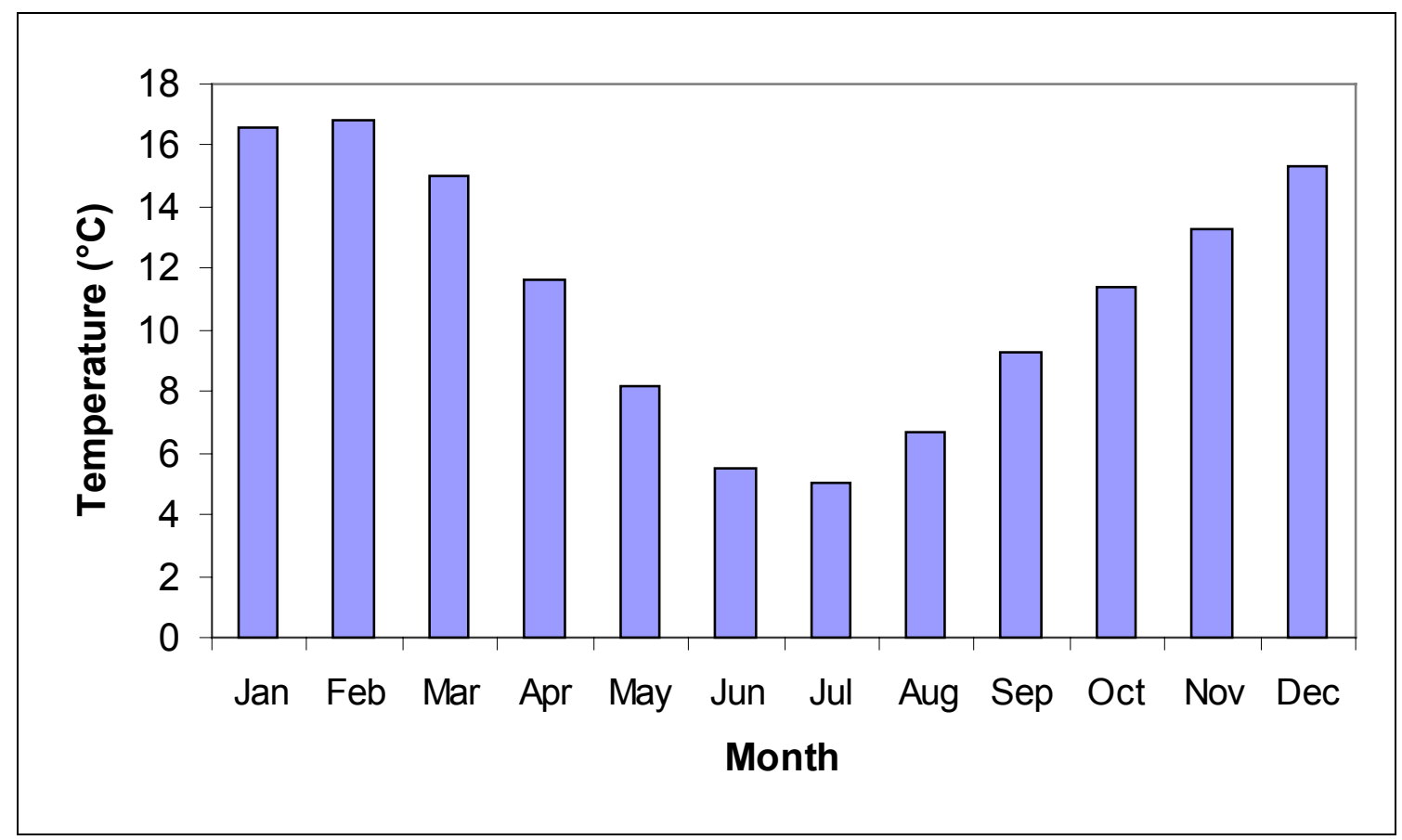

Figure 2.14: Mean monthly temperatures, Reefton EWS 1960 - 2003; Source: NIWA, 2003

Temperatures over the study areas vary greatly. The Kowhitirangi area, represented by the Hokitika data, shows warmer average temperatures and less month-to-month variation. Inland, in the Grey Valley and Reefton areas, there are more frosts during the winter and warmer summer temperatures. Due to these colder winter temperatures the Grey Valley and Reefton areas have longer periods of suppressed plant growth than the Kowhitirangi area, which could affect nitrogen leaching rates.

\subsection{STUDY LOC ATIONS}

The West Coast Region has over 300 recorded bores in its groundwater bore inventory (WRC, 2001). Twenty percent of these are in the Grey Valley, twenty seven percent in the Hokitika/Kowhitirangi area, twenty-two percent in the South Westland area with the remainder scattered through the Reefton/Inangahua and Westport areas.

During 1998 a survey was undertaken by the West Coast Regional Council (WCRC) to investigate the use of different types of effluent disposal/irrigation systems. Of the 374 farms surveyed, $20 \%$ indicated that they used some form of land-based effluent 
irrigation system (WCRC, 1998). This is a low percentage applying to land when compared nationally. For this study land based irrigation was classified as the use of either a vehicle spreader, a travelling irrigator or a manual shift sprayer. With more dairy farms switching to applying their effluent to land, there is an increased need to monitor current conditions so that future changes can be properly assessed and managed.

The results from this survey along with the following criteria were used to help select bores suitable for this study. The site criteria were:

- that the bore had to be on a farm that irrigated dairy shed effluent to land by any of the commonly used methods; or, the bore had to be in an area surrounded by farms disposing dairy shed effluent to land; and,

- that the total selection of sites should cover a range of bores that are used for both dairy shed wash-down and residential supply purposes; and,

- to (if possible) select clusters of bores close to each other to select a series of bores down-gradient of each other; and,

- to select bores that could be easily and reliably accessed.

From this selection criteria 30 suitable bores were located. A total of twenty-two bores were chosen for this study. Nineteen of these were selected especially for this study and three bores from the National Groundwater Monitoring Programme (NGMP) were included. The NGMP is a programme administered by the Institute of Geological and Nuclear Science (GNS) which monitors over 110 bores nationally with the aim of allowing a national comparison of water chemistries. These bores are known as the NGMP bores.

\subsubsection{Ahaura Valley}

Seven study bores are located in the Ahaura Valley (Figure 2.15). The Ahaura Valley is located in the Grey Valley, approximately 35 kilometers north-east of Greymouth and consists mainly of elevated glacial outwash terraces (Figure 2.15). Six bores were sampled solely for the purpose of this study. One further bore from the NGMP, 
the Bertacco bore, is also included in this study area. Detailed information on the site selection criteria is given in Chapter Three: Groundwater Quality.

Six of the seven bores in this valley are located on dairy farms, while the remaining bore, at Galligan's residence, used to be located on a dairy farm but the land has since been subdivided and is now a residential property. However, the surrounding landuse is still used for dairy farming.

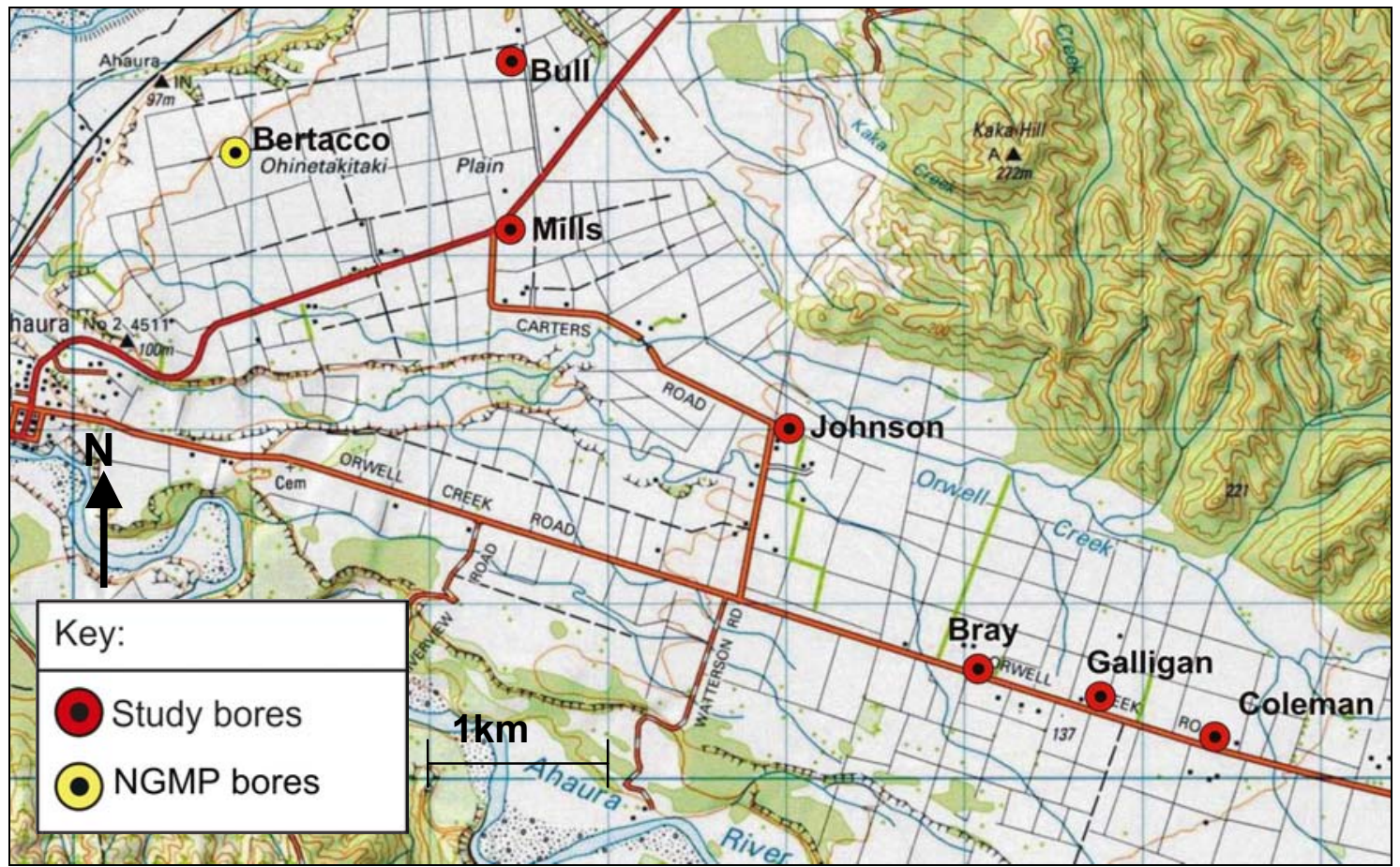

Figure 2.15: Ahaura Valley bores; source: Mapworld Topomap V2.0.61, 2000

\subsubsection{Totara Flat}

A further seven of the study bores are located around the predominantly dairying settlement of Totara flat, approximately $30 \mathrm{~km}$ north-east of Greymouth, also in the Grey Valley (Figure 2.16). All seven bores are on a low glacial outwash terrace alongside the Grey River and are surrounded by dairy farms. To the north-east of Totara Flat, the Havill bore in the settlement of Ikamatua was sampled (Figure 2.16). This bore is located on a high terrace of the Ikamatua plains. 


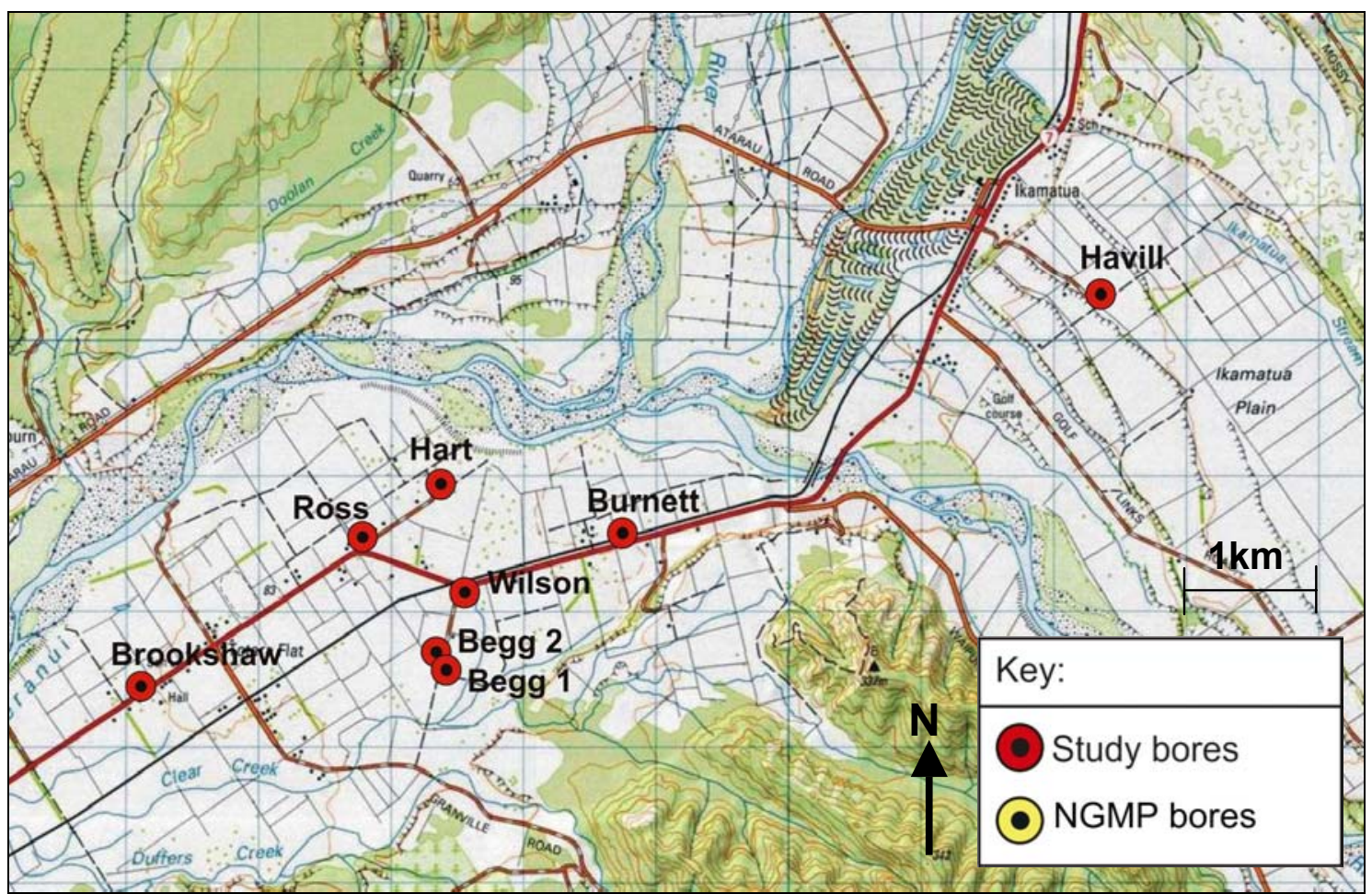

Figure 2.16: Totara Flat bores; source: Mapworld Topomap V2.0.61, 2000

\subsubsection{Kowhitirangi}

Five bores were located in the Kowhitirangi area, $12 \mathrm{~km}$ south-east of Hokitika (Figure 2.17). Three bores in this area were sampled specifically for the study while two, Coleman and Anderson, are from the NGMP. The Kowhitirangi flats are low lying alluvial flats, predominantly used for dairying, bordered by the Kokatahi and Hokitika rivers. All of the bores in this area are surrounded by dairy farms, although one bore was situated at the old school. 


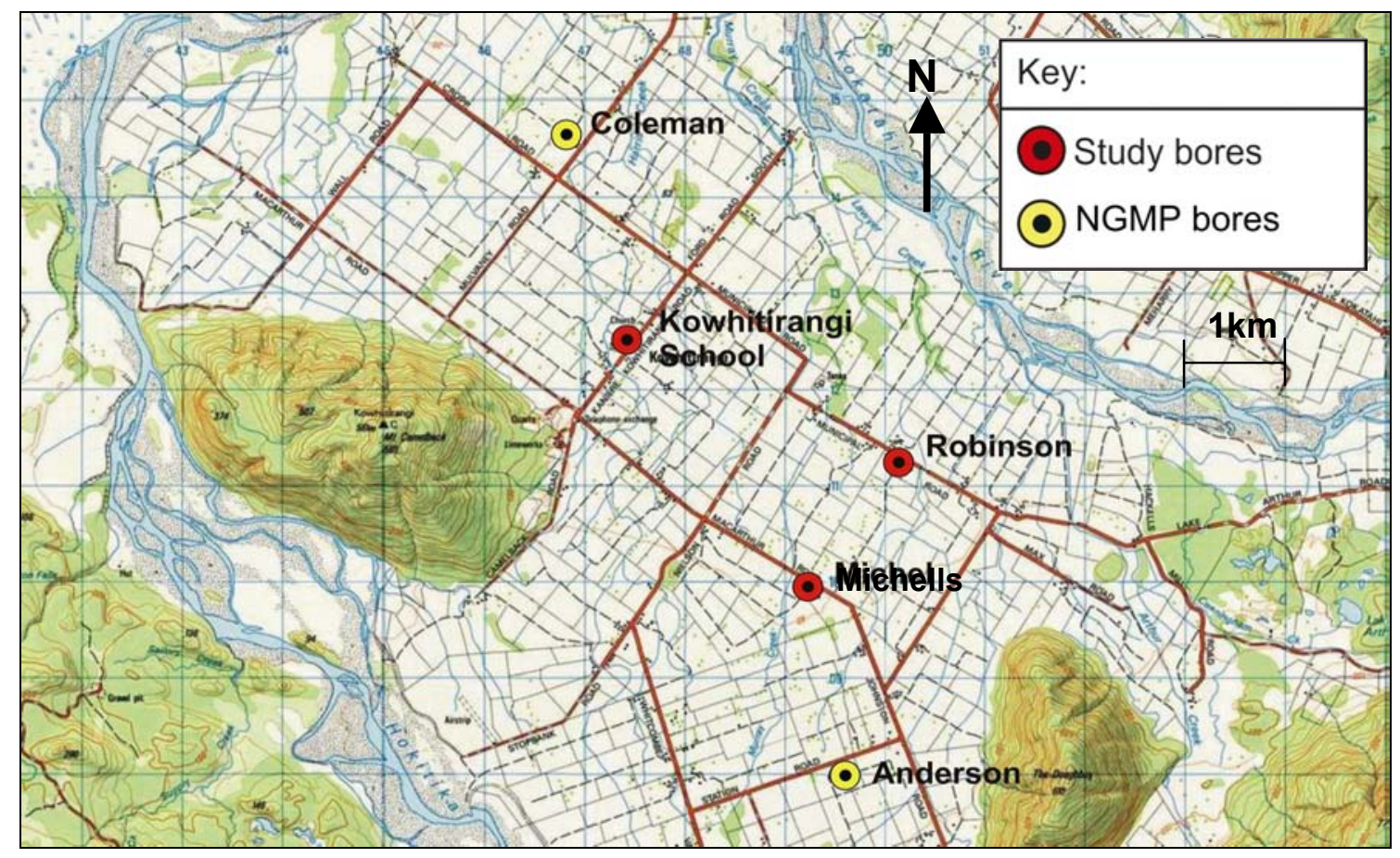

Figure 2.17: Kowhitirangi bores; source: Mapworld Topomap V2.0.61, 2000

\subsubsection{Reefton}

Two bores for the study were located in the Inangahua Valley near Reefton, 65 kilometers north-east of Greymouth (Figure 2.1). The Parkinson bore, $2 \mathrm{~km}$ north of Reefton (Figure 2.18), is located amongst several large dairy farms.

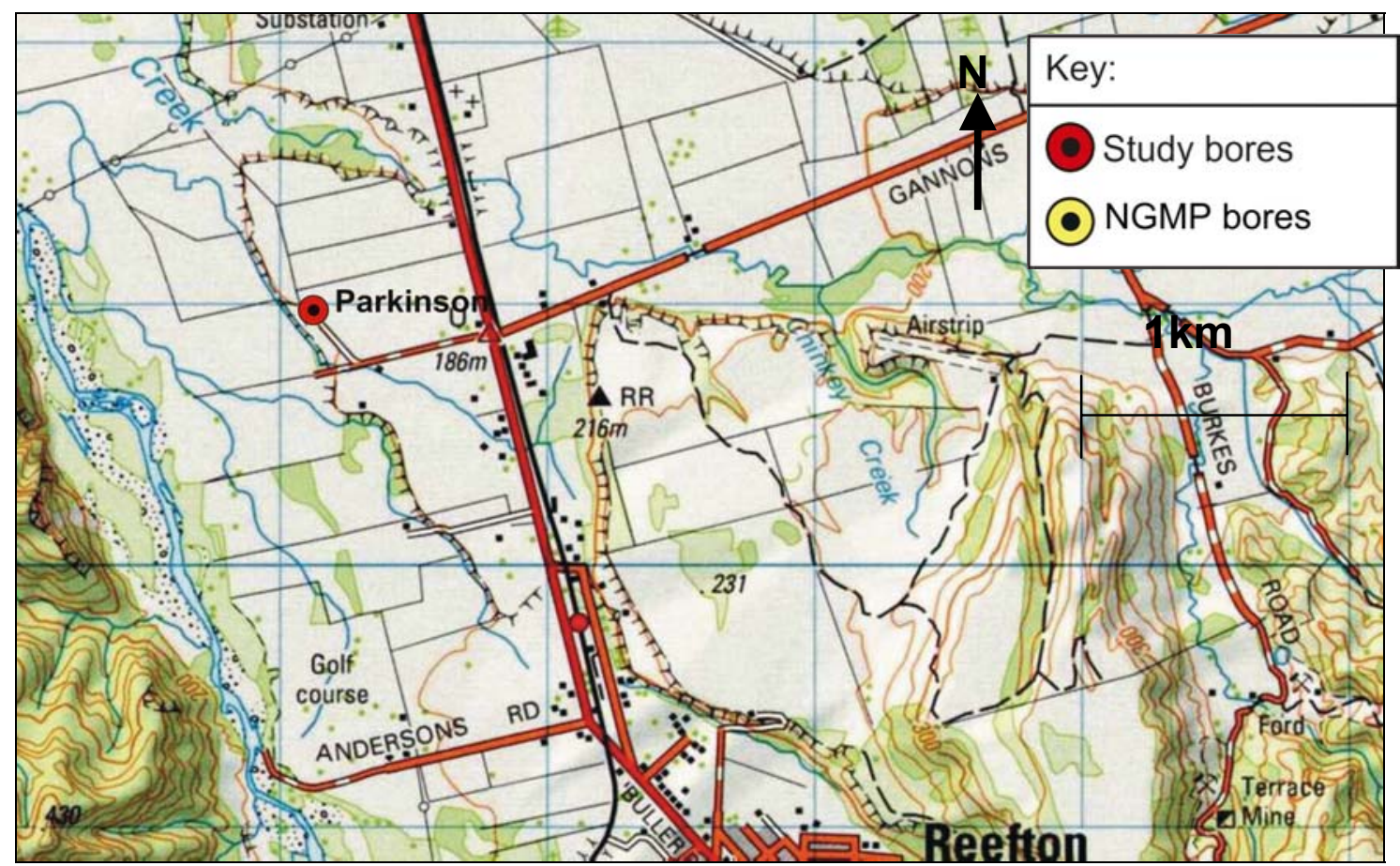

Figure 2.18: Parkinson bore; source: Mapworld Topomap V2.0.61, 2000 
The Mitchell Brothers bore, in Cronadun, 10km north of Reefton (Figure 2.19), is located on a dairy farm; however, there are no other dairy farms upgradient of it.

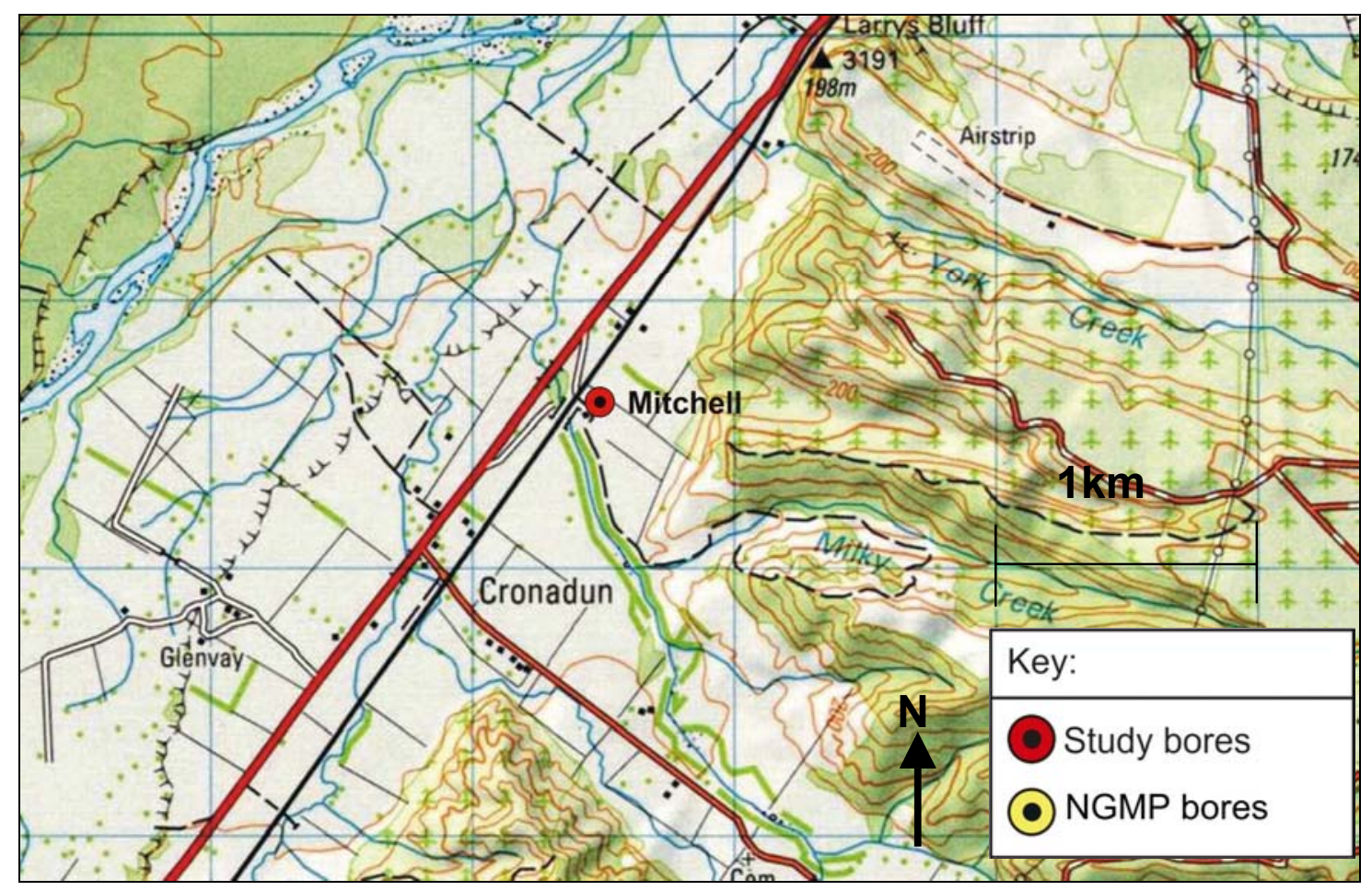

Figure 2.19: Mitchell bore; source: Mapworld Topomap V2.0.61, 2000

In summary, all of the sites chosen for this study are located in areas where the main surrounding landuse is dairying farming. Thus, the potential sources of groundwater contamination are expected to be limited to those associated with dairy farming; however, this is studied in detail through the analysis of groundwater quality set out in chapter four. Prior to this analysis the hyrogeology of the region is discussed. 


\section{HYDROGEOLOGY}

The purpose of this chapter is to outline the general hydrogeology of the aquifers in the study areas. The West Coast Regional Council does not require landowners to obtain a consent for either the construction of a bore or for the abstraction of water from a bore. Bores are not required to be pump tested prior to use either. This has meant that full pump test information is unavailable for any bores in the study areas and driller's pump test information is scarce.

Despite this lack of information it is necessary to characterise and assess the hydrogeology of the study areas. Using the available data and subsequent analysis an appreciation of the movement of contaminants through the groundwater system can be obtained.

\subsection{WEST COAST AQUIFERS}

The primary aquifers on the West Coast, such as those throughout the Grey Valley, are in unconfined gravel outwash terraces. The thickness of the alluvial gravels is typically $20-40 \mathrm{~m}$, and up to $60-70 \mathrm{~m}$ in parts of the Grey Valley, such as in the Ahaura area (James, 2001). The basement of these aquifers is sandstone, mudstone (Kaiata Bluebottom Group in particular) and conglomerate. These shallow unconfined aquifers provide the majority of groundwater abstraction on the West Coast.

Historically drillers have not pump-tested wells to determine hydrogeological properties such as hydraulic conductivity, transmissivity, or porosity. This information was deemed unimportant due to groundwater being regarded as plentiful, and so detailed hydrogeologic information is scarce (James, 2001). Furthermore, even detailed bore log information is often not collected during drilling. However, some generalised bore logs do exist. Recently drillers have become more aware of the need to accurately log bores and future bores will be recorded with more detail (Mears pers comm., 2002). 


\subsection{BORE LOG INFORMATION}

Since historically bore logs have not been taken during drilling, only five bore logs typical of the study areas (Chapter 2, Figures $2.15-2.19$ ) were available from the local drilling company (Westmere Drilling Ltd) at the time of writing.

\subsubsection{Totara Flat}

In the Totara flat area of the Grey Valley water is encountered at depths of between 4 and $6 \mathrm{~m}$ in recent alluvial gravels. These gravels generally occur to a depth of approximately $20 \mathrm{~m}$. Below this unit are clay bound gravels that have a much lower water content. Wells in this area have not been drilled past $12 \mathrm{~m}$ as the water quantity and quality has been sufficient in the shallower gravels.

The Begg farm bore (\#2) (Figure 3-1) is one of the bores sampled as part of this project. Drilled to a depth of $7 \mathrm{~m}$, the bore has Grey gravels to a depth of $6 \mathrm{~m}$. These are a good water-bearing gravel. This bore was drilled to replace the existing bore on the property, Begg bore (\#1), due to the original bore 'drying up' two summers in a row. 


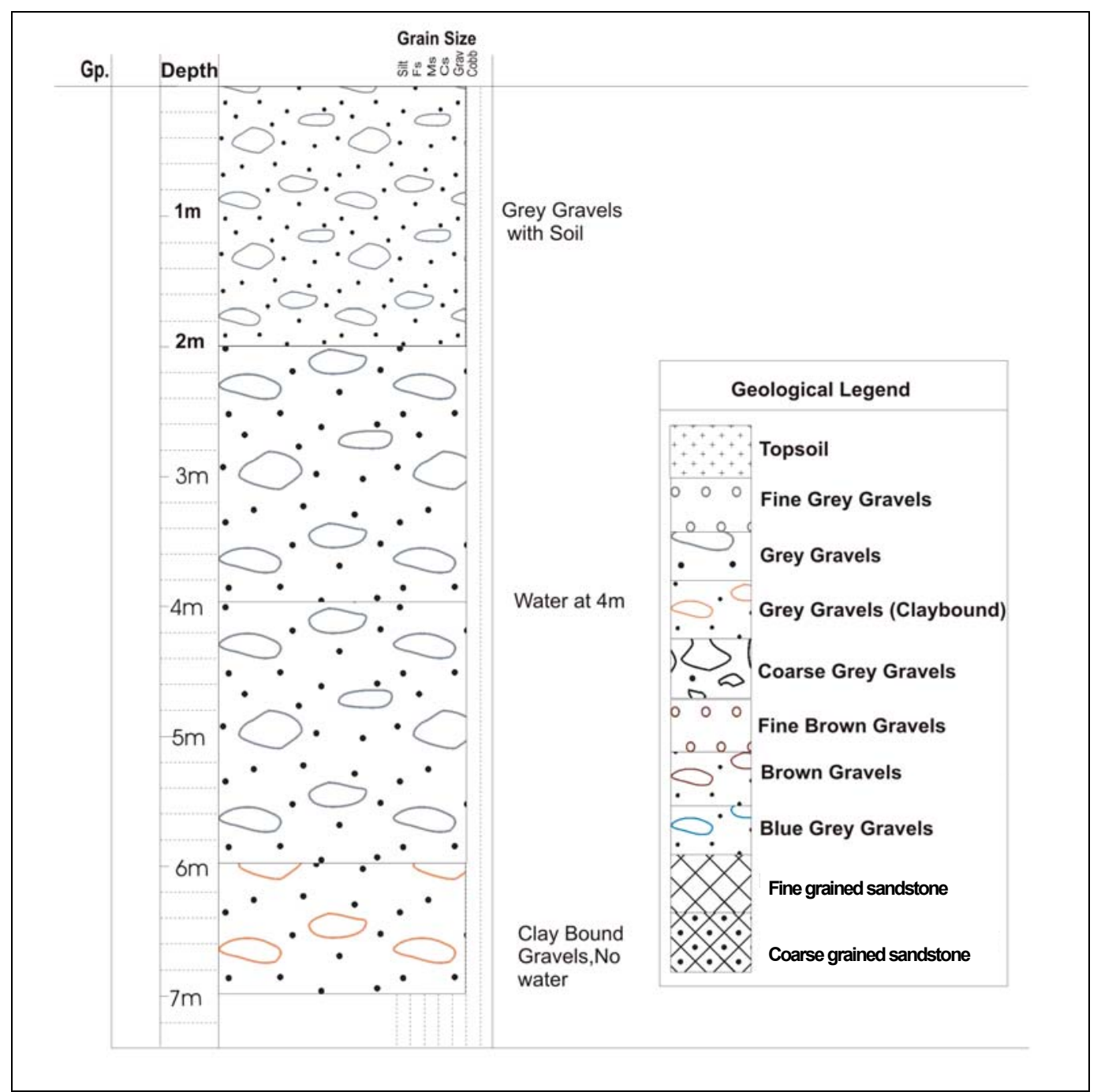

Figure 3-1: Begg Farm Bore \#2 - Totara Flat; Source: Westmere Drilling Ltd, 2002

The Burnett bore, also a sampled bore, at Totara Flat (Figure 3-2) is a deeper bore drilled to a depth of $12 \mathrm{~m}$. Free flowing gravels were found to a depth of $4 \mathrm{~m}$, where a $1 \mathrm{~m}$ thick clay-bound layer was encountered. Below this, finer gravels that had a good flow of water through to a depth of $12 \mathrm{~m}$ were found. 


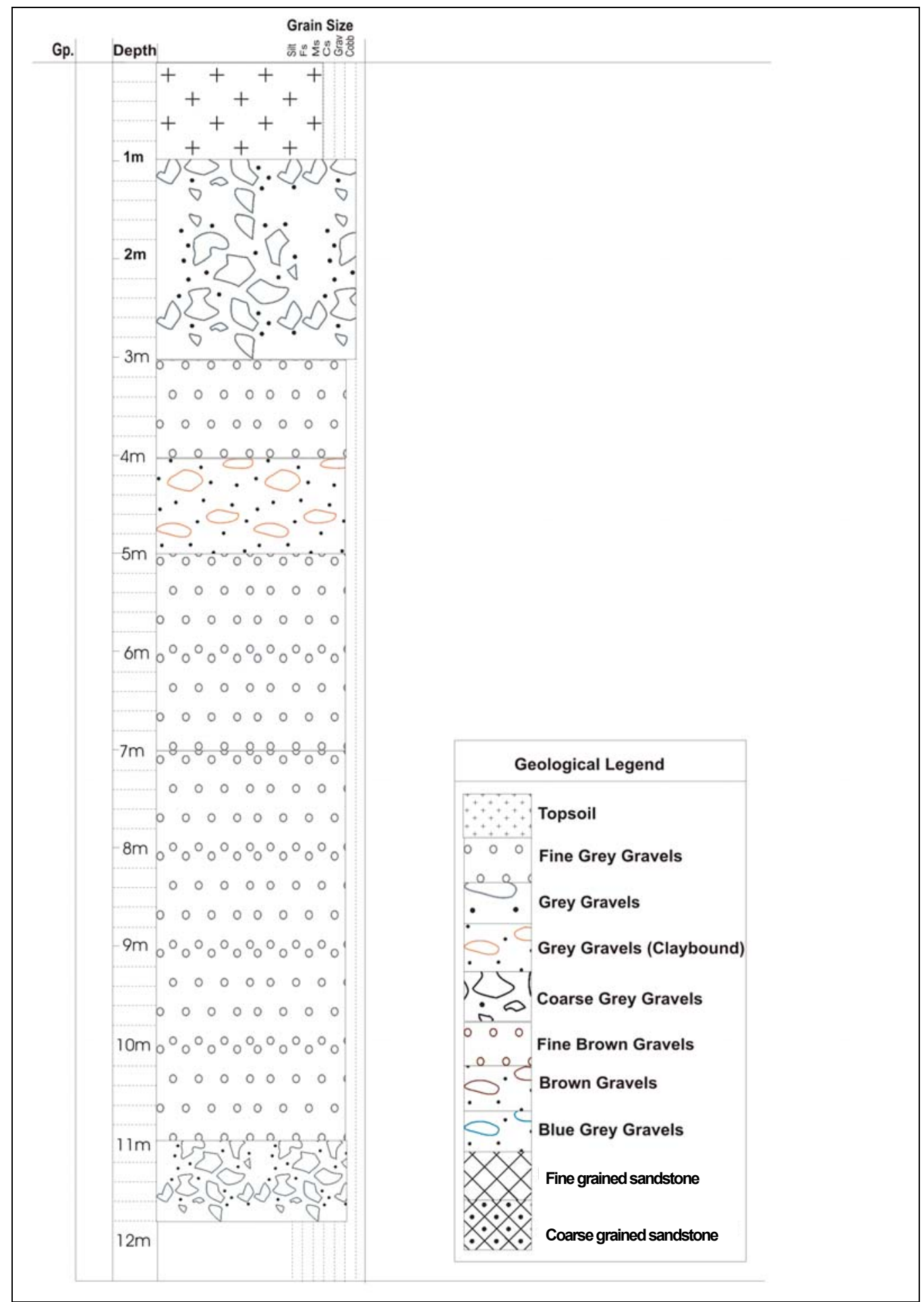

Figure 3-2: Burnett Bore - Totara Flat; Source: Westmere Drilling Ltd, 2002

The School bore at Totara Flat (Figure 3-3) was drilled and cased to a depth of $10 \mathrm{~m}$. It is not sampled in this study, however, it is located within $2 \mathrm{~km}$ of the other Totara Flat bores and gives a good indication of the local geology. Gravels with a high sand content were found in the top 3 to $4 \mathrm{~m}$ of the bore, below which was $3 \mathrm{~m}$ of Grey 
gravels. The water table was at approximately $6.8 \mathrm{~m}$. At $9.6 \mathrm{~m}$ brown gravels were encountered and the flow of water decreased.

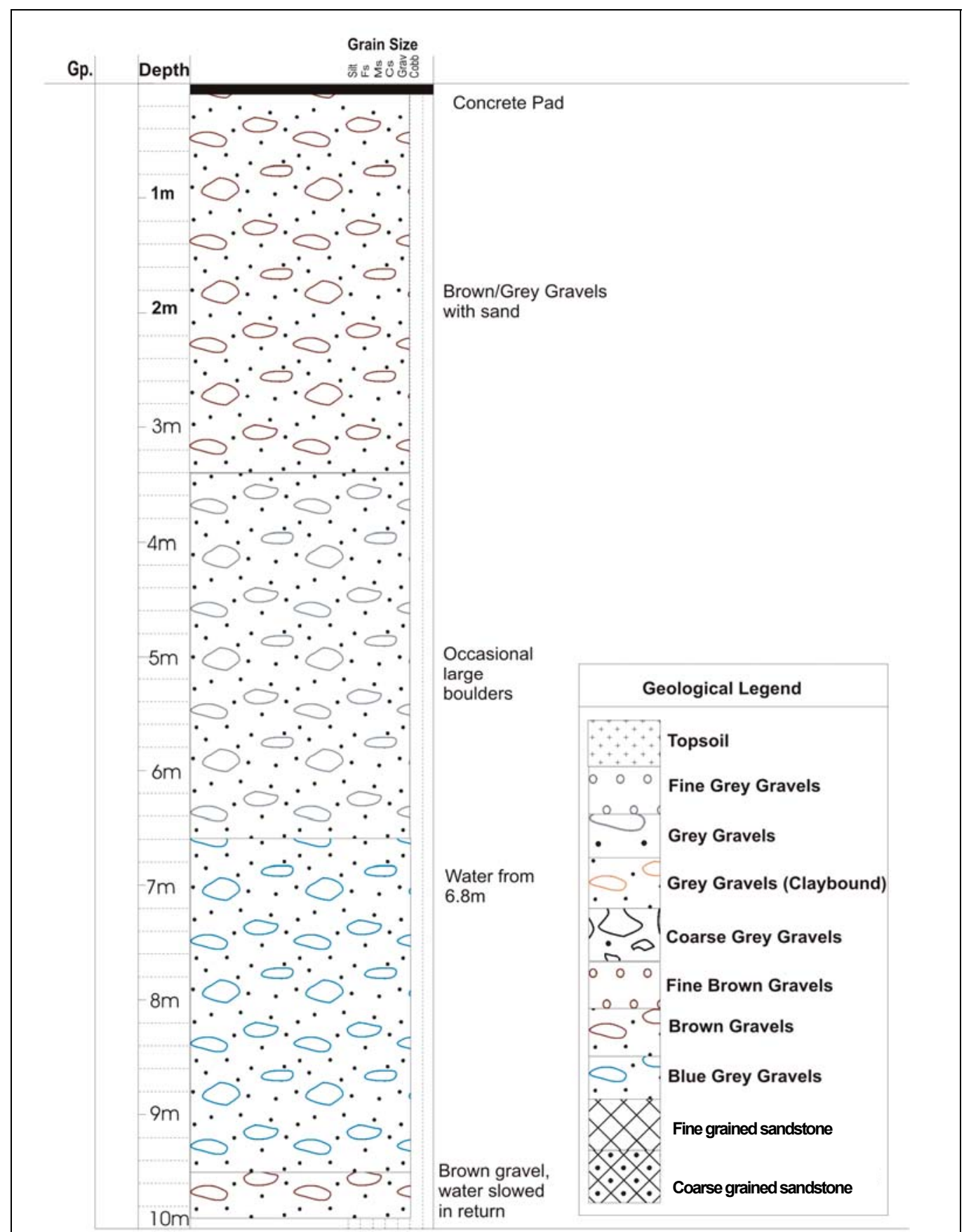

Figure 3-3: School Bore - Totara Flat; Source: Westmere Drilling Ltd, 2002 


\subsubsection{Ahaura Valley}

The Ahaura Valley, situated on a high terrace has much deeper groundwater levels. In the upper valley water levels are typically $20 \mathrm{~m}$ below the surface. However, bores have been drilled to $60 \mathrm{~m}$ in order to achieve a more secure water supply both in terms of water quality, and water quantity (Mills pers. comm., 2001). The following bore log from the Mills (a sampled bore) farm in the Ahaura Valley (Figure 3-4) is believed to show the typical characteristics of the area.

Recent Grey gravels were found to a depth of $9 \mathrm{~m}$, below which brown gravels were encountered to a depth of $25 \mathrm{~m}$. From $28 \mathrm{~m}$ a fine grained sandstone was found, turning into a coarser grained sandstone below $55 \mathrm{~m}$. The static water level in this bore was at $8.65 \mathrm{~m}$ at the time of drilling; however, the bore was put down to $60 \mathrm{~m}$ to prevent the well drying up in the summer. 


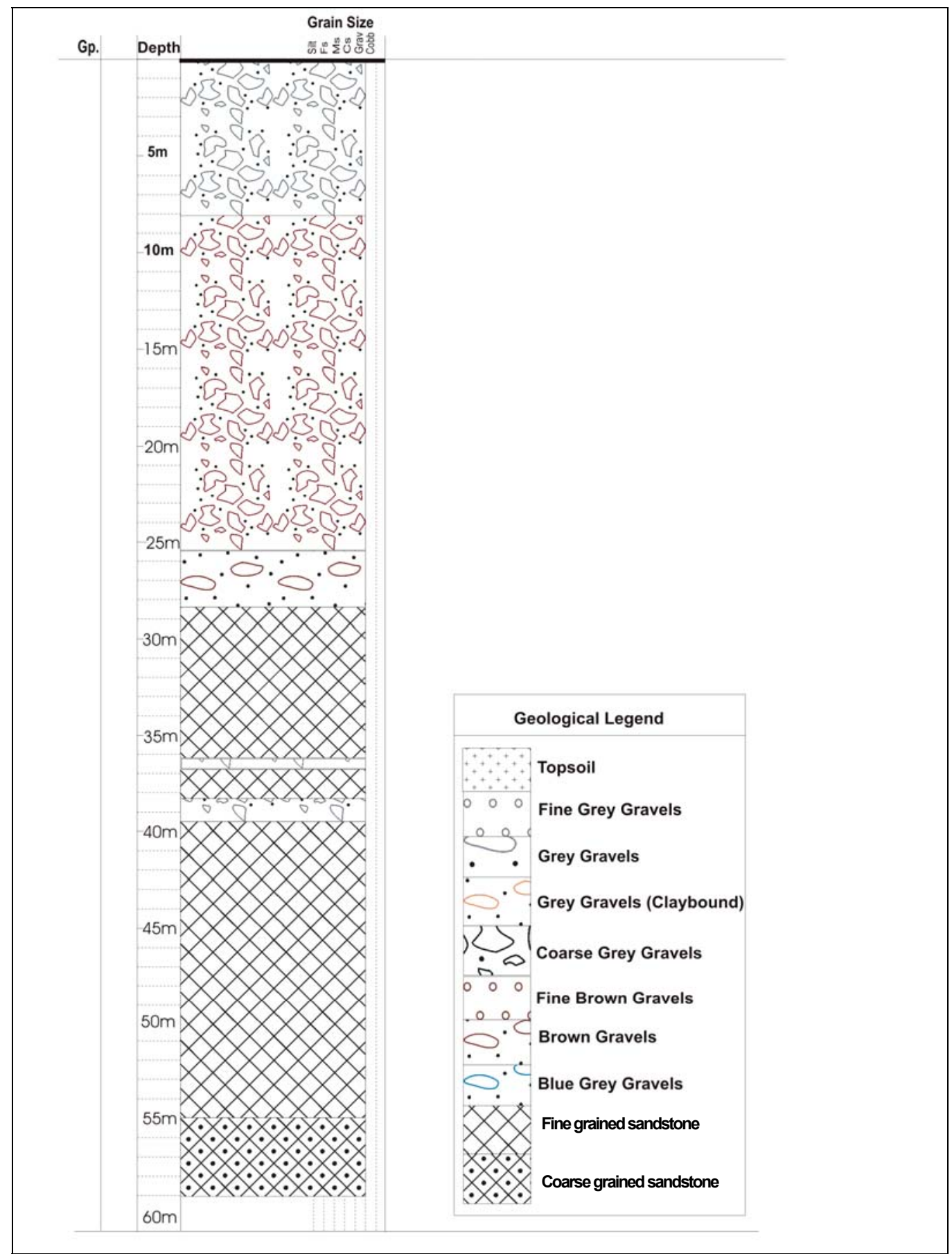

Figure 3-4: Mills Bore - Ahaura Valley; Source: Westmere Drilling Ltd, 2002

The Bertacco bore (Figure 3-5), is also located in the Ahaura Valley and was sampled as part of this study. This bore was drilled to $9 \mathrm{~m}$. An especially high sand content was found between $3 \mathrm{~m}$ and $4 \mathrm{~m}$, below which the gravels were saturated. Water flowed freely at $5.5 \mathrm{~m}$. 


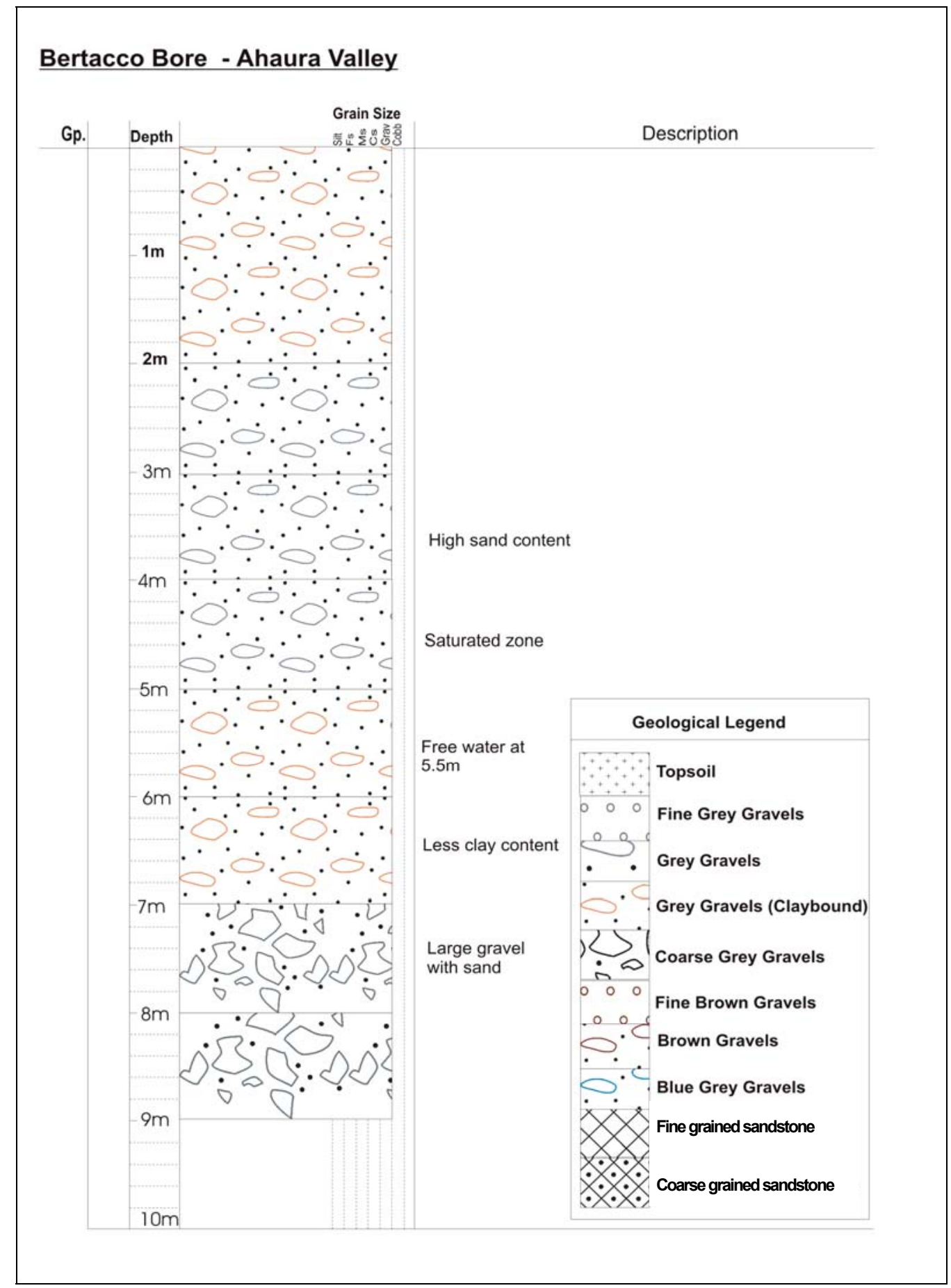

Figure 3-5: Bertacco Bore - Ahaura Valley; Source: Westmere Drilling Ltd, 2002

\subsubsection{Kowhitiran gi}

Recent alluvial gravels covered by a shallow soil profile underlie the Kowhitirangi area. The groundwater levels are shallow, often being only $1 \mathrm{~m}$ below the surface after rain. Due to the high water tables, bores are generally dug by the landowner using an excavator, hence deep bores are seldom constructed and bore log information is unavailable (James pers. comm., 2001). 


\subsection{DRILLERS PUMP TESTS}

Although full pump test data from the West Coast region are unavailable, drillers pump tests have been carried out on several wells. For this sort of test, drillers pump the bore at a known rate and measure the drawdown. There are no standard durations of pumping used by the drillers, but tests are often undertaken until the water level reaches equilibrium.

Using basic drawdown and pump rate information recored at the time of drilling aquifer transmissivity can be calculated. While the lack of information limits the quality of the calculation using simple 'drillers test' methods, where there is limited aquifer test data, it does allow the aquifer transmissivities to be calculated using real field information.

The transmissivity (KD or $\mathrm{T}$ ) of an aquifer is the rate of flow under a unit hydraulic gradient through a cross-section of unit width over the whole saturated thickness of the aquifer (Kruseman \& de Ridder, 1994). Hence, transmissivities are commonly expressed in $\mathrm{m}^{2} /$ day. The aquifer transmissivity is usually derived from full pump tests and require methods of analysis that utilise data on the radius of influence of the well. However, this radius of influence can only be measured by the use of observation wells. While less accurate, the Logan method and the Driscoll methods can be used in situations where only drawdown and discharge data from one bore is available.

For this study, drillers pump test information was only available for five bores. Two bores not sampled as part of this study, Slyus and Coleman new, are used to provide a better spatial spread of transmissivity information.

\subsection{LOGAN ME THOD}

Logan's method was first described by Logan in the 1960s and was first written up in Kruseman and de Ridder (1970). This method is derived from the Theim equation for transmissivity in a confined aquifer but it is also valid for use in the unconfined situation (Kruseman and de Ridder, 1970): 


$$
\mathrm{T}=\left(2.3 \mathrm{Q} / 2 \pi \mathrm{S}_{\mathrm{mw}}\right) \log \left(\mathrm{r}_{\mathrm{e}} / \mathrm{r}_{\mathrm{w}}\right)
$$

Where: $\quad T=$ aquifer transmissivity

$\mathrm{Q}=$ discharge

$\mathrm{S}_{\mathrm{mw}}=$ maximum drawdown

$r_{e}=$ radius of influence of the well, and

$r_{w}=$ well radius

In the Theim equation the ratio $r_{\mathrm{e}} / r_{\mathrm{w}}$ cannot be determined unless there is an extensive network of observation wells during the pump test. Although this ratio may vary considerably, the $\log \left(r_{e} / r_{w}\right)$ term is relatively insensitive to such variations (Misstear, 2002). Logan proposed a value of 3.32 as 'typical', and the following equation was derived from the Theim equation, for the unconfined aquifer situation:

$$
\begin{gathered}
\mathrm{T}=1.22 \mathrm{Q} / \mathrm{S}_{\mathrm{mw}} \\
\mathrm{S}_{\mathrm{mw}}{ }^{\prime}=\mathrm{S}_{\mathrm{mw}}-\left(\mathrm{S}_{\mathrm{mw}}{ }^{2} / 2 \mathrm{D}\right)
\end{gathered}
$$

Where: $\quad \mathrm{T}=$ aquifer transmissivity $\left(\mathrm{m}^{2} /\right.$ day $)$

$$
\begin{aligned}
& \mathrm{Q}=\text { discharge }\left(\mathrm{m}^{3} / \text { day }\right) \\
& \mathrm{S}_{\mathrm{mw}}=\text { maximum drawdown }(\mathrm{m}) \\
& \mathrm{D}=\text { aquifer depth }(\mathrm{m})
\end{aligned}
$$

\subsection{DRISCOLL METHOD}

Transmissivity can also be calculated using the Driscoll method. Driscoll (1986) suggested the relationship between specific capacity and transmissivity for an unconfined aquifer was $T=1500 C_{s}$ (in US Imperial units). Specific capacity is used to express the productivity of a bore, and is derived form the pumping rate, $Q$, divided by the bore drawdown (Misstear, 2002).

Converting Driscoll's equation to SI units gives the equation (Wilson, 2003): 


$$
\mathrm{T}=0.7015 \mathrm{C}_{\mathrm{s}}
$$

Where: $\quad T=$ Transmissivity $\left(\mathrm{m}^{2} /\right.$ day)

$$
\mathrm{C}_{\mathrm{s}}=\text { specific capacity }=\text { discharge }\left(\mathrm{m}^{3} / \text { day }\right) / \text { drawdown }(\mathrm{m})
$$

Driscoll derived his method assuming a transmissivity of $372.6 \mathrm{~m}^{2} /$ day and a specific yield of 0.003 in his calculations. However, the Driscoll method is often reformulated to take into account conditions specific to the study area. Unfortunately, reformulating the equation relies on pump test derived transmissivity values, which are unavailable for the West Coast study areas.

\subsection{RESULTS}

Using the Logan and Driscoll methods the aquifer transmissivities for the five bores were calculated (Table 3-1). The Driscoll method returns a lower transmissivity, which is in the order of $40-70 \%$ of the Logan estimation.

\begin{tabular}{l|l|l|l|l|l|l} 
& $\begin{array}{l}\mathbf{Q} \\
\left(\mathbf{m}^{3} / \mathbf{d a y}\right)\end{array}$ & $\begin{array}{l}\mathbf{S}_{\mathbf{m w}} \\
\mathbf{( m )}\end{array}$ & $\begin{array}{l}\mathbf{D} \\
\mathbf{( m )}\end{array}$ & $\begin{array}{l}\mathbf{T} \text { (from } \\
\text { Logan) } \\
\left(\mathbf{m}^{2} / \mathbf{d a y}\right)\end{array}$ & $\begin{array}{l}\mathbf{T} \text { (from } \\
\text { Driscoll } \\
\text { Bethod) } \\
\left(\mathbf{m}^{2} / \text { day) }\right.\end{array}$ & $\begin{array}{l}\text { Depth of } \\
\text { bore }(\mathbf{m})\end{array}$ \\
\hline $\begin{array}{l}\text { Totara Flat School (Totara } \\
\text { Flat) }\end{array}$ & 216 & 1.2 & 20 & 225 & 126 & 9.9 \\
\hline Burnett (Totara Flat) & 28.8 & 0.15 & 20 & 250 & 134 & 11.8 \\
\hline $\begin{array}{l}\text { Coleman new (Ahaura } \\
\text { Valley) }\end{array}$ & 168 & 4.6 & 60 & 47 & 25.5 & 22 \\
\hline Bertacco (Ahaura Valley) & 576 & 0.5 & 60 & 1152 & 806 & 9 \\
\hline $\begin{array}{l}\text { Sluys (Ahaura Valley) } \\
\text { Tab }\end{array}$ & 216 & 2.5 & 60 & 146 & 60.6 & 18
\end{tabular}

Table 3-1: Transmissivities of West Coast bores derived from the Logan and Driscoll methods. 
Results from the Logan and Driscoll transmissivity $(T)$ methods were generally lower than expected given the alluvial gravel aquifers that dominate the study areas. T values ranged from $47 \mathrm{~m}^{2} /$ day to $1152 \mathrm{~m}^{2} /$ day using the Logan method and from 25 $\mathrm{m}^{2} /$ day to $806 \mathrm{~m}^{2} /$ day using the Driscoll method.

\subsection{DISCUSSION}

Freeze and Cherry (1979) define aquifers suitable for water expolitation as those with a transmissivity value of over $1440 \mathrm{~m}^{2} /$ day. None of the bores tested above meet this guideline. The Logan method gave the highest results, but only the Bertacco bores gave a results in the range expected from clean alluvial gravels $(T=>1000$; Freeze \& Cherry, 1979).

The low transmissivities reported in most of the bores are a reflection both of the clay contents, and the dominance of rainfall recharge in these areas. The raised terraces in the Ahaura Valley and Totara flat area are likely to be dominated by rainfall recharge, whereas the river recharged areas, such as the Kowhitirangi study area, generally have high transmissivities (Mears pers. comm., 2002).

However, it is important to note that the use of these simple equations may yield results that are highly erroneous. Kruseman and de Ridder (1970) suggest that the results from the Logan method may have an error of $+/-50 \%$. Driscoll (1986) suggests errors of less than $7 \%$ have been reported from the use of his method.

One reason for the variation in estimates may be a results of the accuracy of the data. Since the estimation of $T$, in both equations, is a function of specific capacity, there may be significant errors involved. Specific capacity is dependent on pumping rate, pumping time, and well construction. The most important of these is pumping time (Wilson, 2003). The duration of pumping in all of these cases has been dictated by the driller. It is not known, given the information supplied on the bore log, whether or not the bore has reached equilibrium. Farmers on the West Coast are reluctant to spend any extra money conducting pump tests and developing the bores, hence pumping time on completion of drilling is often cut short (Mears pers comm., 2004) 
The lack of well development on the West Coast may also have an effect of the calculation of transmissivity rates. The development of a bore cleans out small sediment found in the strata or left behind from the drilling. The removal of this sediment from around the screen allows water to flow without restriction into the bore. Without development, the flow of water into the bore can be restricted, giving inaccurate drawdown data.

The derivation of constants may also account for the under estimation of $\mathrm{T}$ values. Had it been possible to reformulate the Driscoll equation to better suit the West Coast conditions (high transmissivity alluvial gravels) the use of the method as an estimator may have been more accurate. However, without data on which to base an assessment of the empirically-derived constants used in both equations, the accuracy of either method is unknown.

\subsection{CONCLUSIONS}

Given the large range in $\mathrm{T}$ values it is hard to estimate aquifer transmissivities for these areas. The low $T$ values reported for the Ahaura Valley bores $\left(47 \mathrm{~m}^{2} /\right.$ day -146 $\mathrm{m}^{2}$ /day) are likely to be a reflection of localised high clay contents. The $\mathrm{T}$ value reported in the Bertacco bore high ( $1152 \mathrm{~m}^{2} /$ day), is likely to be a reflection of the clean gravels found at shallower depths. As the geology of the Totara Flat, Reefton and Ahaura Valleys is similar, the above estimations could be applied, with caution, to the aquifers of these areas.

The transmissivities derived above can only be considered first approximations. However, due to the absence of adequate data, and because this research is not solely concerned with groundwater flows, the approximations provide useful indicative information. Future research on groundwater in the West Coast region should include full pump testing to enable the accurate determine of aquifer characteristics. 


\section{GROUND WATER QUALITY}

\subsection{INTRODUC TION}

Dairy farms in New Zealand are generally characterised by a high stocking rate and intensive management relative to other pastoral farming systems in New Zealand (Ledgard et al., 1996). The intensification of dairying in the past ten to fifteen years has resulted in an increase in the number and stocking rate of cows, and an increase in the use of fertilisers and forage supplements to improve farm performance. This increased intensification of farming practices has been associated with greater environmental impacts (reported particularly in the popular press) on both soil and groundwater quality; however, there is a need for research, such as this study, that quantifies and details the relationship between landuse practices and groundwater quality.

There is a need to monitor and sustainably manage the effects of dairying on the groundwater resources for health, economic and environmental reasons and it is a legal requirement of local government authorities under the Resource Management Act (1991). This chapter analyses data collected during this study, and the on-going National Groundwater Monitoring Programme (NGMP) to assess the effects of dairying and its associated practices on the groundwater quality in the most intensively farmed areas of the West Coast.

\subsection{PARAMETER SELECTION}

Given the large number of reasons for testing groundwater quality, such as state of the environment monitoring, point source contaminant studies, drinking water quality testing, it is not surprising that a large number of water quality parameters are tested for in New Zealand. For example, the National Groundwater Quality Monitoring Programme (NGMP) includes testing for all major ions and nutrients. Pesticides are also monitored nationally both by local bodies and through the Institute of Environmental Science and Research's national pesticide survey. For the purposes of this study the parameters to be analysed were selected from those that: 
- result from, or show the presence of, effluent contamination. For example nitrate-nitrogen and chloride have been studied by Burden, 1982; Jarvis, 1993; Silva et al., 1999 and Monaghan et al. 2002;

- are required by $\mathrm{MoH}$ guidelines (2000) for safe drinking water;

- show the presence of other forms of contamination, e.g fertilizer; and,

- render the water unfit for purposes such as stock water, irrigation or milk production.

In addition, other factors impacted upon the final choice of analytes. Strict budgetary constraints limited both the number of analytes able to be selected and the number of times each site could be sampled. Ease of sample collection was also considered in the final selection.

\subsection{PARAMETE RS}

The parameters measured, their usefulness, and their relationship to groundwater quality are detailed below.

\subsubsection{Nitrate-nitrogen}

Nitrate-nitrogen contamination of groundwater is of concern for several reasons. Almost 60 years ago Comley (1945) first noted that high concentrations of nitrate could cause health problems in the form of Methemoglobinemia, more commonly known as 'blue baby syndrome'. The same health concern still forms the basis of today's health guidelines for nitrate levels.

Around $50 \%$ of New Zealand community drinking water supplies use groundwater as either a sole or partial source. In addition, many rural households are supplied by domestic wells (Close et al., 2001). According to the Ministry of Health's Water Information New Zealand Database (WINZ) approximately 15\% of the West Coast Region's population use groundwater as their sole source of drinking water, so the quality of the water in these groundwater resources is an important issue. 
Nitrogen in groundwater can occur in various forms: these are the inorganic ions nitrate $\left(\mathrm{NO}_{3}{ }^{-}\right)$, nitrite $\left(\mathrm{NO}_{2}{ }^{-}\right)$or ammonium $\left(\mathrm{NH}_{4}{ }^{+}\right)$, as well as many organic forms (Hoare et al., 1992). Of these forms, nitrate is the most commonly analysed. The concentrations of nitrogen compounds can be given either as nitrogen or as the ion of interest. For example, a nitrate concentration of $50 \mathrm{~g} / \mathrm{m}^{3}$ is equal to $11.3 \mathrm{~g} / \mathrm{m}^{3} \mathrm{NO}_{3}-\mathrm{N}$ (nitrate-nitrogen). In this thesis, all concentrations are reported as nitrate-nitrogen and $\mathrm{SI}$ units are used, i.e. $\mathrm{mg} \mathrm{L}^{-1}=\mathrm{g} / \mathrm{m}^{3}=\mathrm{ppm}$.

Natural levels of $\mathrm{NO}_{3}-\mathrm{N}$ in New Zealand are generally low because of the high transmissivities in many New Zealand aquifers and the high rainfall over most areas of the country (Close et al., 2001). Burden (1982) suggested that concentrations above $1 \mathrm{~g} / \mathrm{m}^{3} \mathrm{NO}_{3}-\mathrm{N}$ did not occur naturally in New Zealand aquifers, although no scientific basis was given for this value. In some US studies it has been suggested that levels of over $3 \mathrm{~g} / \mathrm{m}^{3} \mathrm{NO}_{3}-\mathrm{N}$ suggest anthropogenic influence; however, in New Zealand it can be assumed that natural occurrences of nitrate would rarely be higher than $1 \mathrm{~g} / \mathrm{m}^{3} \mathrm{NO}_{3}-\mathrm{N}$ (Close et al., 2001).

Sources of nitrates in New Zealand groundwater include both anthropogenic and natural sources. The non-natural sources include animals (deer, sheep, cattle, pigs), fertilisers and human wastes. Fertilisers are more dominant than animal wastes in high production areas such as market gardens whereas clover is used to fix nitrogen in pasture. However, in areas of wetter and cooler climatic conditions, such as the West Coast, nitrogen-based fertilisers are often used in large quantities to boost pasture growth. It is for these reasons that nitrate-nitrogen is the ideal nutrient to use as an indicator for highlighting the effects of agricultural land uses on the groundwater resource.

Due to the importance of nitrogen, Chapter 6 contains detailed information on the Nitrogen Cycle, the health effects of nitrates and the effects of increased nitrogen inputs into the system.

\subsubsection{Ammonium -nitrogen}


Ammonium-nitrogen $\left(\mathrm{NH}_{4}-\mathrm{N}\right)$ in groundwaters can be derived from harmless sources or it may indicate that serious pollution is occurring. In deep, and generally confined groundwaters, ammonium-nitrogen can occur naturally from the reduction of nitrate (Holden, 1970). Ammonium-nitrogen can also be produced from the decay of plant and animal residues in soil. When coupled with Iron ( $\mathrm{Fe}$ ) and Manganese (Mn) concentrations, ammonium concentrations can be used to give an indication of the oxidising or reducing nature of the aquifer. This is because significant concentrations of ammonium ( $>0.1 \mathrm{~g} / \mathrm{m}^{3} \mathrm{NH}_{4}-\mathrm{N}$ ) and total dissolved $\mathrm{Fe}$ and $\mathrm{Mn}$ in solution occur under anaerobic (reducing) conditions (Rosen, 2001b). Elevated levels of ammonium in these cases are of concern mainly due to the aesthetic reasons of unpleasant taste and odour.

However, ammonia can also indicate recent contamination of the groundwater with effluent, either animal or human. The urine of animals and humans contains large quantities of ammonia, and high contents are present in sewage and in many sewage effluents (Holden, 1970). Ammonia is rapidly oxidised through the nitrification process to nitrate-nitrogen and therefore is most useful as an indicator of recent contamination of the groundwater.

\subsubsection{Chloride}

Natural levels of chloride in New Zealand groundwaters are generally low. In general, the contribution of chloride in New Zealand surface and groundwater from the underlying geology is small, meaning the dominant natural source of chloride in New Zealand groundwater is from salts carried in clouds that have been evaporated from seawater (sea spray) (Rosen, 2001b) and are therefore low.

As chloride is a major component of salt, it is associated with both human and animal wastes. Chloride is not generally a dominant ion in fertilisers. Hence, elevated levels of chloride in New Zealand are generally associated with sewage contamination.

\subsubsection{Dissolved Reactive Phosphorus}


New Zealand soils are commonly low in phosphorus and so fertilisers have often been applied to increase total phosphorus and plant available phosphorus in soils. Hence, elevated levels of phosphorus in New Zealand groundwaters are often the result of agricultural runoff or excess fertiliser application. The most common source of phosphorus pollution in New Zealand groundwater is from fertiliser use (Rosen, 2001b). Dissolved Reactive Phosphorus (DRP) is the dissolved form of phosphorus that is immediately available to plants (Hoare et al, 1992), and is the most commonly analysed form used for assessing groundwater quality.

Elevated levels of DRP in groundwater (generally caused by fertilisers) are of concern because they can have a large impact on down-gradient surface water bodies. While phosphorus is essential for all plant growth, elevated levels can lead to weed growth and eutrophication in surface waters (Rosen, 2001b). In many surface waters the natural vegetation will have adjusted to a particular N:P ratio, so disturbance of this ratio, can lead to changes in habitat suitability.

\subsubsection{Iron}

Iron in New Zealand groundwater is usually derived from rocks, minerals and leaching from soils (Davies, 2001). Shallow unconfined aquifers are generally low in iron unless the water is slow moving and oxygen is consumed along the flow path through reactions with organic matter and other chemicals (Rosen, 2001). Moderately reducing or anaerobic aquifer conditions are normally required before significant levels of iron are found, because the oxidised form of iron is virtually insoluble except in very acidic waters.

The concern over high levels of iron in groundwaters is restricted mainly to aesthetic reasons. Elevated levels of iron cause red stains in plumbing, toilets and pipes and can also produce an unpleasant taste.

\subsubsection{Bacteriological Indicators}

Faecal coliforms are a group of rod-shaped bacteria that are found in large numbers in the gut of warm blooded animals. Although some coliforms can be found in 
unpolluted water, most are of faecal nature (Sinton, 2001). Faecal coliforms are used as an indicator organism because their presence indicates faecal contamination of the water and indicates the possibility of other harmful pathogens such as cholera, typhoid and dysentery (Bramwell, 2000). Thus the detection of faecal coliform bacteria is used to assess the suitability of water for human consumption, stock water requirements and irrigation supply.

One faecal coliform species, Escherichia coli, is associated only with faecal waste from warm blooded animals. Thus $E$. coli is used by the Ministry of Health to assess the suitability for drinking water under the New Zealand drinking water standards (MoH, 2000).

\subsection{7 $\mathrm{pH}$}

The $\mathrm{pH}$ of water is a measurement of the hydrogen ion concentration. At high concentrations $\mathrm{pH}$ is low (acidic) while at low concentrations $\mathrm{pH}$ is high (alkaline). While a high $\mathrm{pH}$ can result in a distinctive taste and a soapy feel in drinking water (MoH, 2000) the significance of $\mathrm{pH}$ as an indicator of water quality is the way it affects other chemical reactions and the solubility of metal ions.

\subsubsection{Temperature}

The temperature of groundwater affects the rate and nature of chemical reactions and therefore the suitability of water for domestic, stock and recreational use. Temperatures in groundwater are generally stable and any changes that occur are gradual; a rapid change would warrant investigation. Temperature, along with the other field measurements of electrical conductivity and dissolved oxygen were also used in this study to indicate that a bore was properly purged prior to collecting the water sample.

\subsubsection{Dissolved Oxygen (DO)}

The dissolved oxygen concentration is a measure of the oxygen content of the groundwater. The DO content of groundwater can vary greatly and ranges from zero 
up to full saturation (>100\%). Oxygen deficiency, indicating reduced aquifer conditions, is frequently associated with the presence of dissolved ferrous iron (Holden, 1970).

\subsubsection{Electrical Conductivity (EC)}

Electrical conductivity is a measure of the ability of water to conduct an electrical current. It is controlled by the concentration of ions in solution i.e., the total dissolved solids (TDS). As time and distance from the groundwater recharge area increases, natural ion concentrations generally increase, due to rock water interactions (Butcher, 1996). Hence EC is useful as an estimate of the salts in the groundwater and can be used to indicate the possible presence of contaminants.

\subsection{STANDARD S AND GUIDELINES}

The levels of each of the above parameters can be measured; however, the measurements themselves must be put into context to have real meaning. As with all water quality parameters the levels of interest are a function of the intended use of the water, hence a range of water quality guidelines exist in New Zealand.

Drinking water standards are administered by the Ministry of Health, and updated periodically. The New Zealand Drinking Water Standards (2000) use a prioritised system of monitoring, with four prioritised classes for contaminants in drinking water (Davies, 2001). Microbiological contaminants are given the highest priority. Chemical contamination is given second priority as the effects from chemical contamination are less acute than those from microbiological contamination. Recreational, aesthetic and stock-water guidelines used in this study are taken from the Australian and New Zealand Environment and Conservation Council (ANZECC).

It is important to note that for the New Zealand drinking water standards guideline values are used for contaminants that affect the taste, appearance and odour of the water but are not, in themselves, a significant health risk (Davies, 2001). These guideline values often tend to be objective. The Maximum Acceptable Values (MAVs) indicate the maximum concentration of that contaminant which does not result in any 
significant risk to the health of a $70 \mathrm{~kg}$ consumer over a lifetime of consumption of two litres of the water per day (Davies, 2001).

\begin{tabular}{l|l|l} 
Constituent & \multicolumn{1}{|c|}{ Guideline Value/MAV } & \multicolumn{1}{c}{ Rationale } \\
\hline Nitrate-N & $11.3 \mathrm{mg} / \mathrm{l}(\mathrm{MAV})$ & Public health \\
\hline Ammonia & $1.5 \mathrm{mg} / \mathrm{l}$ & Taste, odour \\
\hline Chloride & $250 \mathrm{mg} / \mathrm{l}$ & Taste, corrosion \\
\hline Faecal Coliforms & $<1$ in a 100ml sample & Public health protection \\
& $(\mathrm{MAV})$ & \\
\hline E. Coli & $<1$ in a 100ml sample & Public health protection \\
\hline Iron & $(\mathrm{MAV})$ & \\
\hline pH & $0.2 \mathrm{mg} / \mathrm{l}$ & Staining, corrosion \\
\hline
\end{tabular}

Table 4-1: Ministry of Health drinking water guidelines (MoH, 2003)

\begin{tabular}{l|l|l} 
Constituent & \multicolumn{1}{|c|}{ Guideline Value } & \multicolumn{1}{c}{ Rationale } \\
\hline Nitrate-N & $30 \mathrm{mg} / \mathrm{l}$ & Acute poisoning \\
\hline Chloride & $30-700 \mathrm{mg} / \mathrm{l}$ & Depends on crop \\
\hline Faecal Coliforms & $1000 \mathrm{in} \mathrm{a} 100 \mathrm{ml}$ sample & \\
\hline Iron & $1.0 \mathrm{mg} / \mathrm{l}$ &
\end{tabular}

Table 4-2: Sock water guidelines (ANZECC, 2000)

\begin{tabular}{l|l|l}
\multicolumn{1}{c|}{ Constituent } & \multicolumn{1}{c|}{ Guideline Value } & \multicolumn{1}{c}{ Rationale } \\
\hline Nitrate-N & $10 \mathrm{mg} / \mathrm{l}$ & Public health \\
\hline Ammonia & $0.01 \mathrm{mg} / \mathrm{l}$ & Taste, odour \\
\hline Chloride & $400 \mathrm{mg} / \mathrm{l}$ & Taste, corrosion \\
\hline Faecal Coliforms & $<150 \mathrm{in} \mathrm{a} 100 \mathrm{ml}$ sample & Public health protection \\
\hline E. Coli & $<150 \mathrm{in}$ a $100 \mathrm{ml}$ sample & Public health protection \\
\hline Iron & $0.3 \mathrm{mg} / \mathrm{l}$ & Staining, corrosion \\
\hline pH & $5.0-9.0$ &
\end{tabular}

Table 4-3: Recreational water use guidelines (ANZECC, 2000) 
The guideline values and maximum allowable values are useful in terms of placing levels of contamination into perspective; however, the purpose of this thesis is not to assess the suitability of the groundwater for a particular purpose but to determine the effects that dairying in the region may have on water quality. To assess the influence of landuse on groundwater quality both the set of parameters measured and the sampling design are critical.

\subsection{SAMPLING METHODOLOGY}

Having selected 19 bores using the criteria outlined above, sampling was carried out bi-monthly over an 8-month period. This period started during the autumn month of April and finished during the spring month of October. The accuracy of water quality results is a function of both the analytical techniques and the actual collection procedures, thus the following procedures were followed.

Each bore was purged prior to sampling. Purging the bores entailed in-situ monitoring of $\mathrm{pH}$, conductivity, temperature and dissolved oxygen content until they had settled and remained steady. This generally equated to approximately 15 minutes pumping. Purging the bore ensures a sample representative of the true aquifer conditions, and not the water siting in the bore, is collected.

Samples were collected in bottles prepared and supplied by Cawthron Institute Laboratories in Nelson. Water for nutrient analysis was collected in a $250 \mathrm{ml}$ polythene bottle, treated with $1 \mathrm{ml} 4 \% \mathrm{HgCl}_{2}$. Water for microbial analysis was collected in a $150 \mathrm{ml}$ sterile container and water for trace metals was collected in a $100 \mathrm{ml}$ polythene bottle, treated with $0.1 \%$ Nitric Acid. Upon collection the bottles were stored on ice, and kept below $4^{\circ} \mathrm{C}$ until reaching the Cawthron Laboratories in Nelson (within 24 hours).

\subsection{ANALYSIS METHODOLOGY}

Conductivity, $\mathrm{pH}$, temperature and dissolved oxygen were measured in the field using standard water quality instruments. That is: 
- $\mathrm{pH}$ was measured using a EDT instruments FE257 portable Micro $\mathrm{pH}$ meter. This meter has a resolution of $0.01 \mathrm{pH}$, and an accuracy to $+/-0.02 \mathrm{pH}$.

- dissolved oxygen was measured using a HACH DO175 Dissolved Oxygen meter. This meter has a resolution of $0.1 \%$ and an accuracy of $+/-1 \% \mathrm{FS}$.

- conductivity was measured using a HACH CO150 Conductivity meter, model 50150 . This meter has an accuracy of $+/-0.5 \% \mu \mathrm{S} / \mathrm{cm}$.

- temperature was measured with both the $\mathrm{pH}$ meter and the dissolved oxygen meter to ensure accuracy but the reading was always taken with the $\mathrm{pH}$ meter.

Analysis of nutrients, trace metals and microbial contaminants was carried out by the Cawthron Institute laboratories in Nelson. As this project was funded by the West Coast Regional Council, their existing contract with Cawthron was used to ensure data continuity and accuracy. Cawthron analysed the contaminants using the following methods:

- Faecal Coliforms: APHA 20th Edn 1998, Method 9222D

- E. coli: APHA 20th Edn 1998, Method 9222D

- Ammonia-N: Flow injection analysis (APHA 20th Edn 1998, Method $4500 \mathrm{NH} 3 \mathrm{H})$

- Nitrate-N: Ion Chromatography (APHA 20th Edn 1998, Method 4110B)

- DRP: Flow injection analysis (APHA 20th Edn, Method 4500P G)

- Chloride: Ion Chromatography (APHA 20th Edn 1998, Method 4110B)

- Iron: Flame AAS (APHA 20th Edn 1998, Method 3111B mod)

Ensuring correct calibration of the field instruments and maintaining consistent sampling procedure are often overlooked. Both of these practices are very important to ensure that the samples provided to the laboratory are of the highest possible standard. By observing these practices the author is confident in the accuracy of the data collected. 


\subsection{RESULTS}

The results from the water quality sampling of the 19 study bores and long-term data from the NGMP locations are given in this section. The results are laid out according to their geographical location, as they are grouped in Chapter Two: Study Area. Full tables of results are given in Appendix 2.

\subsubsection{Rainfall}

Rainfall, both long-term averages and the 2001 monthly totals, are given (Figure 4.1, Figure 4.2). Rainfall is an important consideration in water quality studies. Both the amount of rain, and temporal variations in rainfall, can have a influence on groundwater by affecting the amount and timing of water flow, and the nature and concentration of potential contaminants moving through the system.

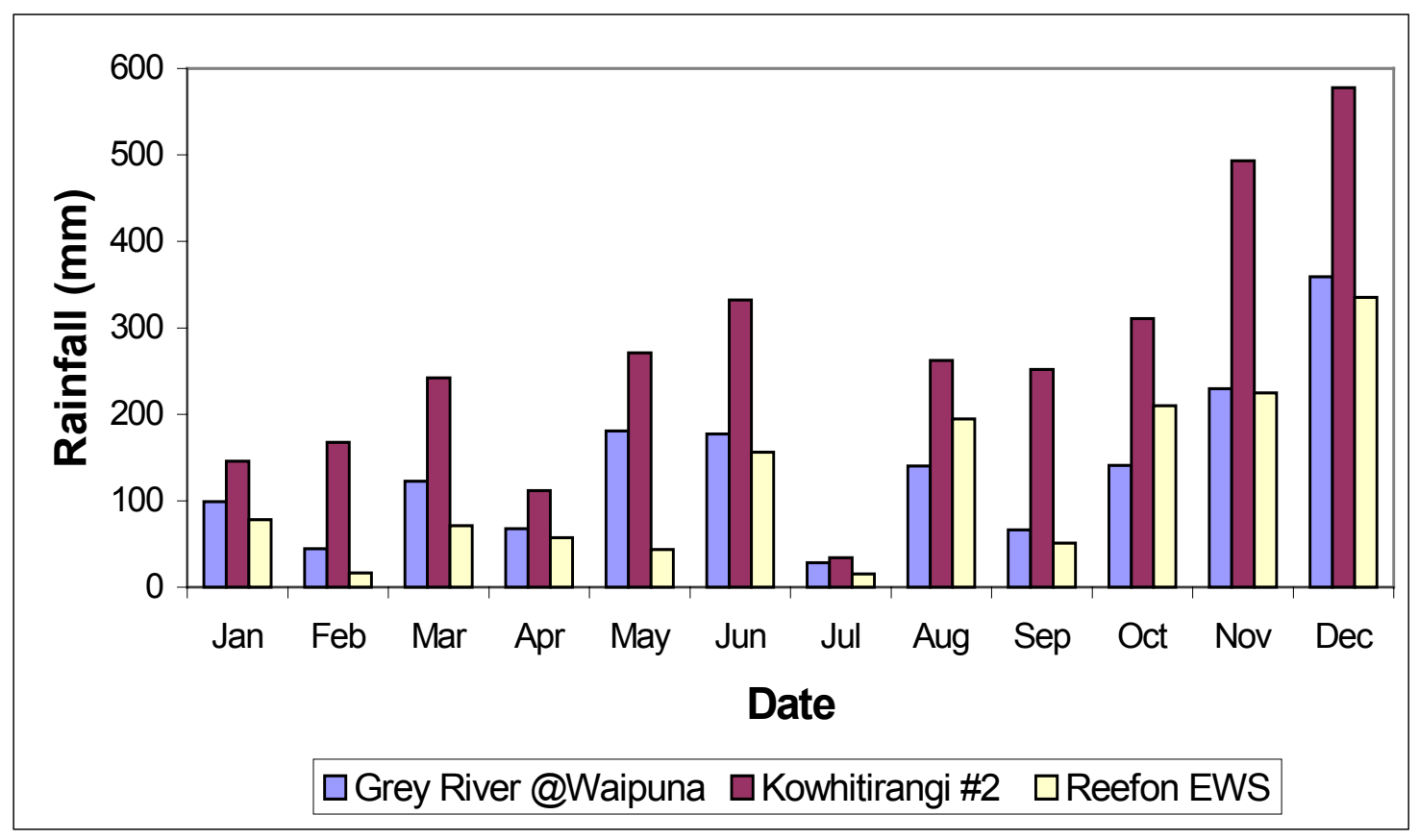

Figure 4.1: West Coast monthly rainfall, 2001; source: NIWA, 2002.

Rainfall during 2001 was spatially and temporally variable over the West Coast. During 2001 there was considerably more rainfall at Kowhitirangi $(3199 \mathrm{~mm})$ than in the Grey Valley $(1655 \mathrm{~mm})$, and in the Inangahua Valley $(1454 \mathrm{~mm})$ (Figure 4.1). This is primarily due to the rain-shadow effect of the Paparoa ranges on the Grey and 
Inangahua river valleys, while the Kowhitirangi area lies directly seaward of the Southern Alps. In addition to the spatial variation the 2001 monthly totals varied considerably from the long term average values (Figure 4.2).

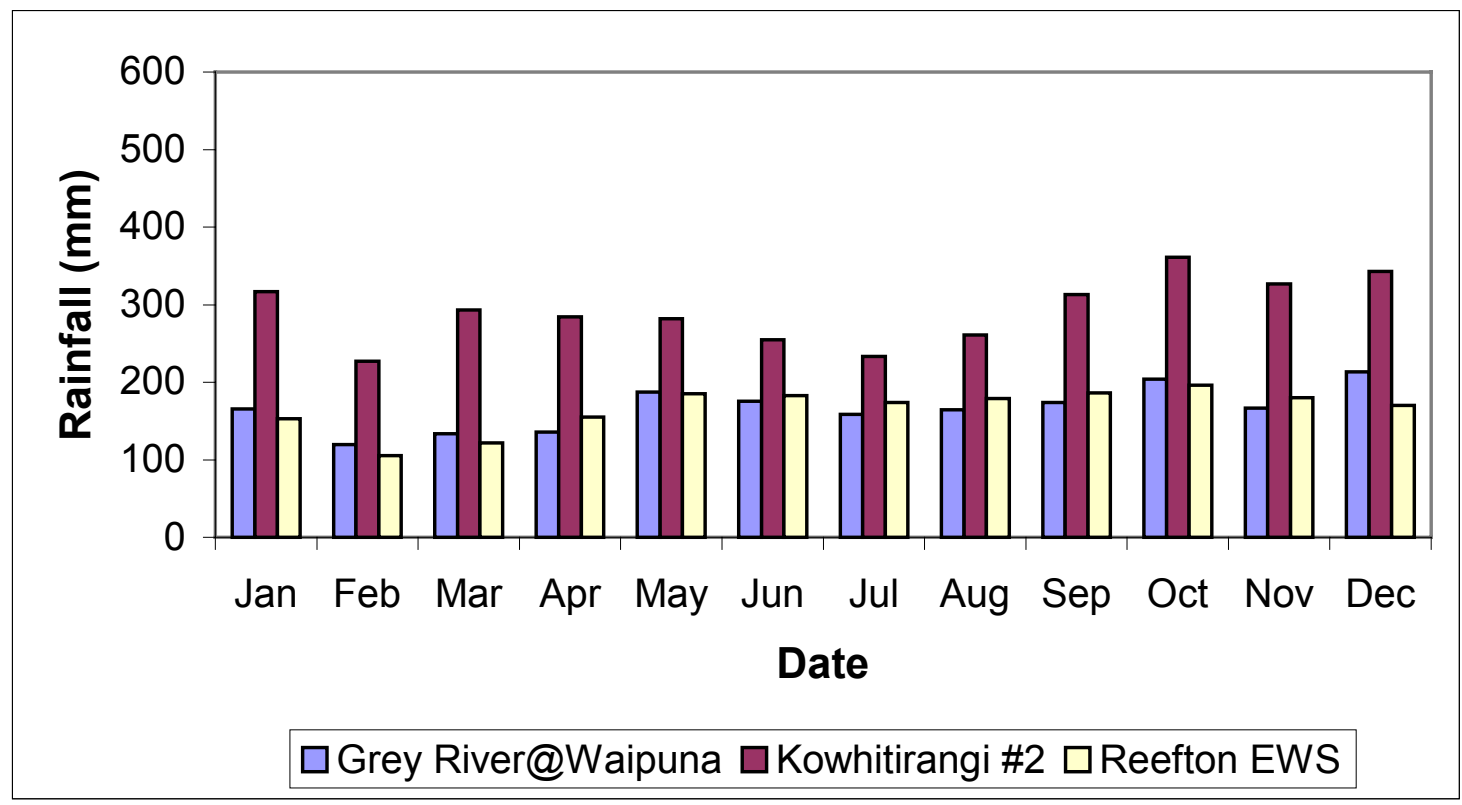

Figure 4.2: Long-term monthly rainfall averages, Waipuna (June 1981 to Oct 2003), Kowhitirangi \#2 (Feb 1965 to Apr 2002), Reefton EWS (Aug 1960 to May 2002); source: NIWA (2003), WCRC (2004).

Lower than average totals were recorded through January, February and March. April was unseasonably dry followed by a wet May and June. July was again extremely dry (Figure 4.1, Figure 4.2). The spring months provided excellent growing conditions with good rainfall and warm temperatures (MAF, 2002) but were followed by wet summer months.

Both the soils and underlying geology of an area will also affect how rainfall may influence water quality. In some cases, often influenced by the time of sampling, high rainfall may lead to increased concentrations of contaminants due to high throughflows. Under different conditions, higher rainfall may lead to decreased concentrations of contaminants due to dilution. These effects of rainfall and groundwater levels are examined further following this section on the water quality results. 


\subsubsection{Water Quality}

The raw analyte results from the 19 study bores are initially compared to the Ministry of Health drinking water guidelines (2000). This is because the primary groundwater quality concern is with the supply of safe drinking water. It is important to note that the MoH drinking water standards are the strictest used in New Zealand, so water meeting these guidelines will also meet the recreational and stock-water guidelines. In cases where a parameter is not included in the drinking water standards the next most appropriate set of guidelines or maximum allowable values (MAV) are used, that is the ANZECC recreational and ANZECC stock water guidelines. With the results put into context, through the comparison to guidelines and MAVs, the results with respect to landuse are discussed.

\subsubsection{Ahaura Val ley Water Quality}

\subsubsection{Nitrate Con centrations}

Nitrate concentrations are given for the six study bores in the Ahaura Valley (Figure 4.3). The location of the bores in the Ahaura Valley allows the detection of possible down gradient trends in the shallow aquifer in addition to temporal patterns. Water table depths in the Ahaura valley range from 4-5m deep at the Mills farm down to 15$20 \mathrm{~m}$ deep at the deep bores at the top of the valley such as Coleman, Johnson, Galligan and Bray. 


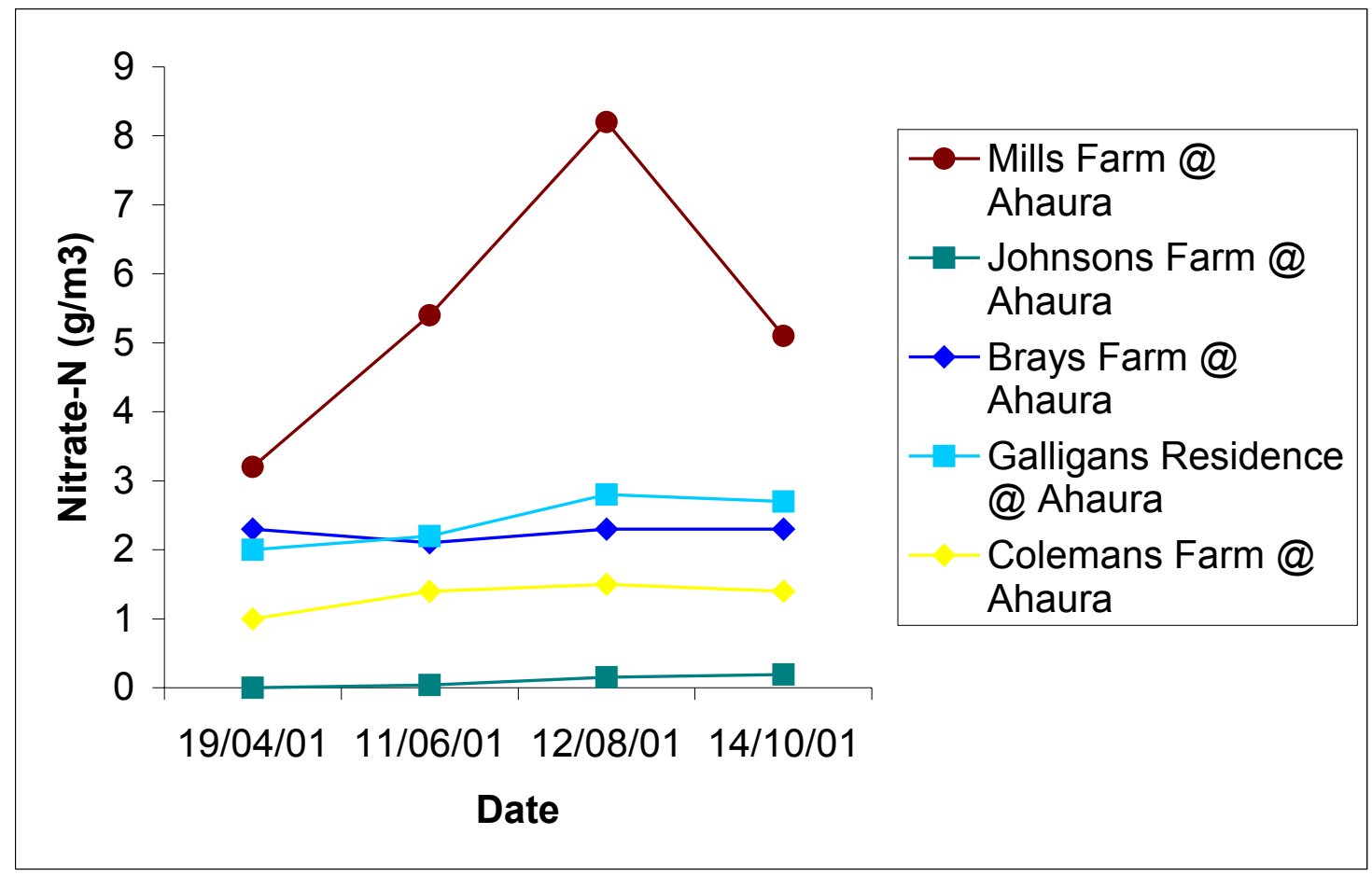

Figure 4.3: Nitrate concentrations in the Ahaura Valley, April - September 2001

Nitrate concentrations in the Ahaura Valley ranged from $0.016 \mathrm{~g} / \mathrm{m}^{3}$ to $8.2 \mathrm{~g} / \mathrm{m}^{3}$. While none of these sample results exceed the $\mathrm{MoH}$ drinking water guideline of $11.3 \mathrm{~g} / \mathrm{m}^{3}$, $80 \%$ of the results are above that which can be regarded as the natural nitrate level of $1-3 \mathrm{~g} / \mathrm{m}^{3}$ (Rosen, 2001b). The highest concentrations at all bores were recorded during the winter (August) sampling round.

Mills farm bore, which recorded the highest levels of nitrate in the valley, is situated in the lower Ahaura valley (Figure 2.15). While all of the bores in the valley are in the unconfined aquifer, Mills farm is one of the shallower bores in the valley with a total depth of $10 \mathrm{~m}$ and an average depth to the water table water of $5 \mathrm{~m}$ compared the deeper wells further up the valley, such as Coleman and Bray, which are 30 and 48 meters deep respectively with water tables around the $15-20 \mathrm{~m}$ depths. 


\subsubsection{Ion and Nutrient Concentrations}

\begin{tabular}{l|c|c|c|c} 
Bore & $\begin{array}{c}\text { DRP } \\
\mathbf{( g / \mathbf { m } ^ { 3 } )}\end{array}$ & $\begin{array}{c}\mathbf{I R O N} \\
\mathbf{( g / \mathbf { m } ^ { 3 } )}\end{array}$ & $\begin{array}{c}\mathbf{C l} \\
\mathbf{( g / \mathbf { m } ^ { 3 } )}\end{array}$ & $\begin{array}{c}\mathbf{N H}_{\mathbf{4}} \mathbf{- N} \\
\mathbf{( g / \mathbf { m } ^ { 3 }} \mathbf{)}\end{array}$ \\
\hline Mills Farm @ Ahaura & $0.01(0.01)$ & $0.17(0.00)$ & $10.90(1.15)$ & $0.02(0.01)$ \\
Johnsons Farm @ Ahaura & $0.05(0.03)$ & $3.38(3.17)$ & $6.23(0.23)$ & $0.01(0.00)$ \\
Brays Farm @ Ahaura & $0.04(0.01)$ & $0.58(0.71)$ & $6.67(0.21)$ & $0.01(0.00)$ \\
Galligans Residence @ Ahaura & $0.02(0.00)$ & $0.11(0.03)$ & $7.13(0.55)$ & $0.02(0.01)$ \\
Colemans Farm @ Ahaura & $0.03(0.01)$ & $0.14(0.08)$ & $6.20(0.30)$ & $0.01(0.00)$ \\
Bulls Farm @ Ahaura & $0.01(0.00)$ & $0.05(0.00)$ & $6.87(1.02)$ & $0.02(0.01)$
\end{tabular}

Table 4-4: Mean (std dev) ion and nutrient concentrations, Ahaura Valley. Shaded cells exceed MoH drinking water MAVs/Guidelines (2001). Note: Mean and median values over the four sampling periods were similar, medians are reported in Appendix 2.

Dissolved Reactive Phosphorus (DRP) levels varied from $0.011 \mathrm{~g} / \mathrm{m}^{3}$ to $0.047 \mathrm{~g} / \mathrm{m}^{3}$. There are no guideline values or maximum allowable values set for phosphorus levels in New Zealand but the values recorded in this study are lower than the NGMP average which is below $0.1 \mathrm{~g} / \mathrm{m}^{3}$.

Average iron levels in the Ahaura Valley exceeded the drinking water maximum allowable values (MAV's) at the Bray and Johnson bores. However, the Johnson bores result was skewed by one high result, hence the large standard deviation. Large changes in iron levels are not expected in groundwater over short periods of time so this result could be a reflection of a sampling error, or inadequate bore purging, or the presence of iron oxide particles bought out of the bore on pumping.

Chloride levels ranged from $6.2 \mathrm{~g} / \mathrm{m}^{3}$ up to $10.2 \mathrm{~g} / \mathrm{m}^{3}$. These levels are lower than the drinking water maximum allowable value of $250 \mathrm{~g} / \mathrm{m}^{3}$ and the ANZECC stock-water guidelines of $30-700 \mathrm{~g} / \mathrm{m}^{3}$.

Ammonium-nitrogen levels in the Ahaura Valley were also consistently low. Values varied from $0.009 \mathrm{~g} / \mathrm{m}^{3}$ to $0.018 \mathrm{~g} / \mathrm{m}^{3}$ with standard deviations of $0.0 \mathrm{~g} / \mathrm{m}^{3}$ to 0.01 
$\mathrm{g} / \mathrm{m}^{3}$. All of these values are well below the $\mathrm{MOH}$ drinking water maximum allowable value of $1.5 \mathrm{~g} / \mathrm{m}^{3}$.

\subsubsection{Microbial Results}

Faecal coliform bacteria and the coliform species Escherichia coli were monitored at all sites during all four sampling rounds. The measurement of faecal coliforms is important as their occurrence is an indicator of the possible presence of pathogens. Faecal coliform results were identical to the $E$. coli results suggesting the occurrence of only the E. coli species of faecal coliforms (Figure 4.4), which suggests faecal contamination from warm blooded animals.

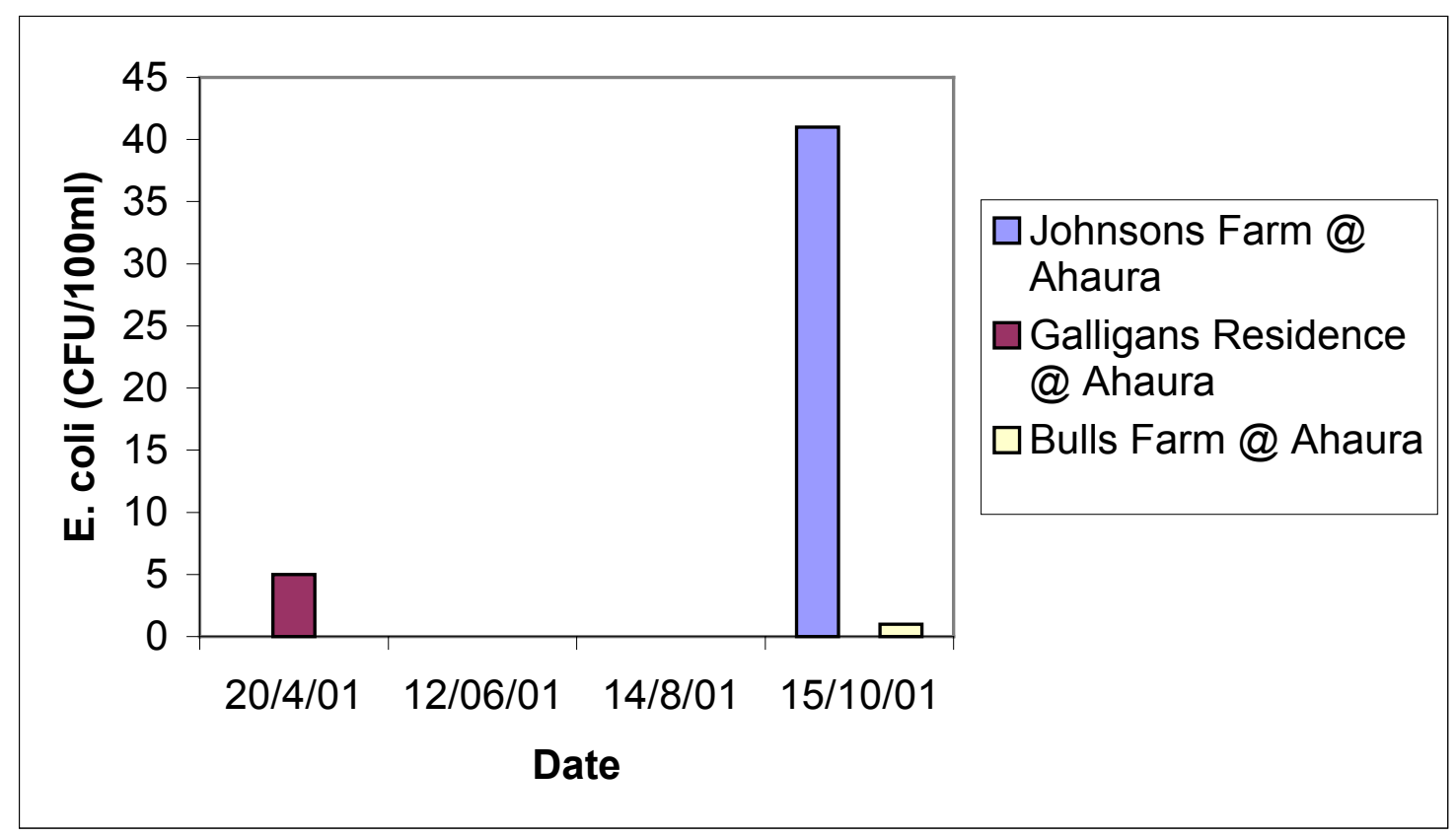

Figure 4.4: E.coli occurrences in Ahaura Valley bores

Analysis of the bore water showed isolated occurrences of E. coli in Johnsons, Galligans, and Bulls farm. All three farms recorded $E$. coli counts on only one of the four sampling rounds, but in each case these were above the MAV of the New Zealand Drinking Water Standards (2000). No counts of E. coli were recorded during the June and August sampling rounds. 


\subsubsection{4 $\mathrm{pH}$, electric al conductivity (EC) and temperature}

Bores were sampled in the field for $\mathrm{pH}$, electrical conductivity (EC), temperature, and dissolved oxygen. $\mathrm{pH}$ values in the Ahaura valley showed only slight spatial and temporal variability with average values from 5.80 to 6.9 and standard deviations ranging from 0.0 to 0.7 (Table 4-5). Average $\mathrm{pH}$ levels in the valley were all lower than the New Zealand Drinking Water Standards guidelines of 7.0 - 8.5 (MoH, 2001).

Electrical conductivity values varied spatially and temporally with mean values ranging from $105.3 \mu \mathrm{S} / \mathrm{cm}$ to $222.5 \mu \mathrm{S} / \mathrm{cm}$ and standard deviations ranging from 25.8 $\mu \mathrm{S} / \mathrm{cm}$ to $74.1 \mu \mathrm{S} / \mathrm{cm}$ (Figure 4.5 ).

\begin{tabular}{l|c|c}
\multicolumn{1}{c|}{ Bore } & pH & EC $(\mu \mathrm{S} / \mathbf{c m})$ \\
\hline Mills Farm @ Ahaura & $5.9(0.7)$ & $170.1(74.1)$ \\
\hline Johnsons Farm @ Ahaura & $6.9(0.6)$ & $222.5(62.3)$ \\
\hline Brays Farm @ Ahaura & $6.3(0.3)$ & $172.5(43.0)$ \\
\hline Galligans Residence @ Ahaura & $5.8(0.7)$ & $137.4(39.6)$ \\
\hline Colemans Farm @ Ahaura & $5.8(0.3)$ & $105.3(25.8)$ \\
\hline Bulls Farm @ Ahaura & $6.2(0.0)$ & $133.7(41.7)$
\end{tabular}

Table 4-5: Mean (std dev) pH and EC, Ahaura Valley. Shaded cells do not meet MoH drinking water MAVs/Guidelines (2001).

Temperature results were also variable (Table 4-6). Mean values ranged from 11.1 ${ }^{\circ} \mathrm{C}$ to $13.2^{\circ} \mathrm{C}$ and standard deviations ranged from $0.05^{\circ} \mathrm{C}$ to $4.6^{\circ} \mathrm{C}$.

\begin{tabular}{l|c|c}
\multicolumn{1}{c|}{ Bore } & Temp. $\left({ }^{\circ} \mathbf{C}\right)$ & DO (\%) \\
\hline Mills Farm @ Ahaura & $12.7(0.7)$ & $67.1(13.1)$ \\
\hline Johnsons Farm @ Ahaura & $10.4(2.8)$ & $32.6(22.0)$ \\
\hline Brays Farm @ Ahaura & $12.9(0.05)$ & $47.7(11.5)$ \\
\hline Galligans Residence @ Ahaura & $11.1(2.9)$ & $43.1(6.2)$ \\
\hline Colemans Farm @ Ahaura & $12.2(0.6)$ & $37.1(1.8)$ \\
\hline Bulls Farm @ Ahaura & $13.2(3.4)$ & $75.6(5.2)$
\end{tabular}


Table 4-6: Mean (std dev) temperature and dissolved oxygen values, Ahaura Valley.

Dissolved oxygen measurements ranged from $32.6 \%$ to $75.6 \%$. The higher values of dissolved oxygen were measured in the shallower bores such as Mills farm and Bulls farm. Standard deviation of dissolved oxygen levels ranged from $1.8 \%$ at Colemans farm to $22.0 \%$ at Johnsons farm. The lowest value of $32.6 \%$ was recorded from Johnsons farm bore. The large deviation in DO levels at the Johnson bore may be related to the large fluctuations in groundwater level recorded at this bore.

\subsubsection{Totara Flat Water Quality}

\subsubsection{Nitrate Con centrations}

Nitrate concentrations in the Totara Flat area showed a distinct winter peak (Figure 4.5), similar to that in the early results from the NGMP (Figure 1.2). Concentrations were well below the drinking water MAV of $11.3 \mathrm{~g} / \mathrm{m}^{3}$ but the average concentrations of $1.53 \mathrm{~g} / \mathrm{m}^{3}$ to $3.6 \mathrm{~g} / \mathrm{m}^{3}$ suggest that nitrate levels are elevated from their natural levels.

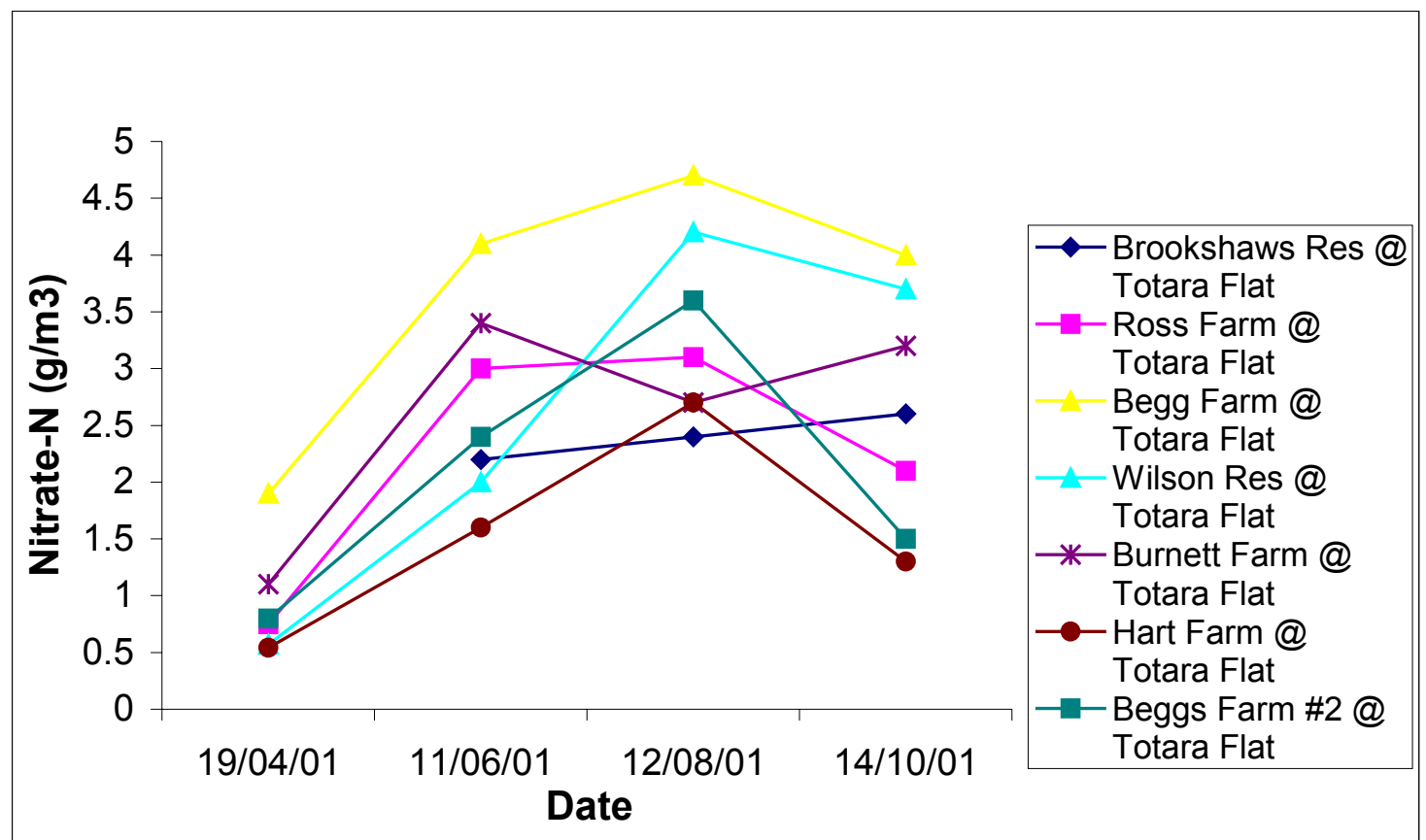

Figure 4.5: Nitrate concentrations at Totara Flat, April - September 2001. 
Groundwater levels at Totara Flat were much shallower than in the Ahaura Valley with levels ranging from 2.8 to $4.5 \mathrm{~m}$ below the surface and bore depths between $4.5 \mathrm{~m}$ and $8 \mathrm{~m}$. These shallower depths are reflected by the higher mean nitratenitrogen concentrations at Totara Flat than in the Ahaura Valley where water levels are deeper.

\subsubsection{Ion and Nutrient Concentrations}

\begin{tabular}{l|c|c|c|c} 
Bore & $\begin{array}{c}\mathbf{D R P} \\
\mathbf{( g / \mathbf { m } ^ { 3 } )}\end{array}$ & $\begin{array}{c}\mathbf{I R O N} \\
\mathbf{( g / \mathbf { m } ^ { 3 } )}\end{array}$ & $\begin{array}{c}\mathbf{C l} \\
\mathbf{( g / \mathbf { m } ^ { 3 } )}\end{array}$ & $\begin{array}{c}\mathbf{N H}_{4}-\mathbf{N} \\
\mathbf{( g / \mathbf { m } ^ { 3 } )}\end{array}$ \\
\hline $\begin{array}{l}\text { Brookshaws Res @ Totara } \\
\text { Flat }\end{array}$ & $0.01(0.00)$ & $0.05(0.00)$ & $6.70(0.42)$ & $0.01(0.00)$ \\
\hline Ross Farm @ Totara Flat & $0.03(0.02)$ & $0.05(0.00)$ & $6.33(1.79)$ & $0.05(0.08)$ \\
\hline Begg Farm @ Totara Flat & $0.01(0.00)$ & $0.07(0.00)$ & $9.80(1.97)$ & $0.04(0.06)$ \\
\hline Wilson Res @ Totara Flat & $0.01(0.00)$ & $0.27(0.27)$ & $5.53(1.66)$ & $0.01(0.00)$ \\
\hline Burnett Farm @ Totara Flat & $0.01(0.00)$ & $0.05(0.00)$ & $5.40(0.79)$ & $0.01(0.01)$ \\
\hline Hart Farm @ Totara Flat & $0.01(0.00)$ & $0.05(0.00)$ & $5.37(0.72)$ & $0.02(0.01)$ \\
\hline Havill Farm @ Ikamatua & $0.02(0.00)$ & $0.05(0.00)$ & $7.97(1.55)$ & $0.01(0.00)$ \\
\hline Beggs Farm \#2 @ Totara Flat & $0.01(0.00)$ & $0.79(0.48)$ & $5.53(1.80)$ & $0.06(0.02)$
\end{tabular}

Table 4-7: Mean (std dev) ion and nutrient concentrations, Totara Flat. Shaded values exceed MoH drinking water MAVs/Guidelines.

Dissolved Reactive Phosphorus levels in the Totara flat area were all low. Average concentrations ranged from $0.007 \mathrm{~g} / \mathrm{m}^{3}$ to $0.021 \mathrm{~g} / \mathrm{m}^{3}$, much lower than the results from the Ahaura Valley.

Chloride concentrations showed little spatial variation, with the average values of seven bores ranging from $5.4 \mathrm{~g} / \mathrm{m}^{3}-7.9 \mathrm{~g} / \mathrm{m}^{3}$ and one bore, Beggs farm, with a value of $9.8 \mathrm{~g} / \mathrm{m}^{3}$. All values were well below the $\mathrm{MoH}$ drinking water maximum allowable values and guidelines. 
Average ammonium concentrations in the Totara Flat area ranged from $0.008 \mathrm{~g} / \mathrm{m}^{3}$ to $0.056 \mathrm{~g} / \mathrm{m}^{3}$. The three highest values were recorded in the two bores at Beggs farm and the bore at Ross farm.

Iron levels in the Totara Flat area were generally low although the average total iron values at the Wilson residence and Beggs farm bore \#2 exceeded $\mathrm{MoH}$ drinking water guidelines.

\subsubsection{Microbial Results}

Positive results for E. coli was recorded at two different sites in the Totara Flat area. During the first sampling round in April an $E$. coli count of $5 \mathrm{cfu} / 100 \mathrm{ml}$ was recorded at the Begg farm bore (Figure 4.6). No further E. coli levels were detected in the following sampling rounds. The samples collected at the Ross farm bore recorded levels of $E$. coli in three of four sampling rounds. In the first and second sampling rounds levels of $8 \mathrm{cfu} / 100 \mathrm{ml}$ and $1 \mathrm{cfu} / 100 \mathrm{ml}$ respectively were recorded. No coliforms were present in the third round but the fourth sample collected in October 2001 had a count of $33 \mathrm{cfu} / 100 \mathrm{ml}$.

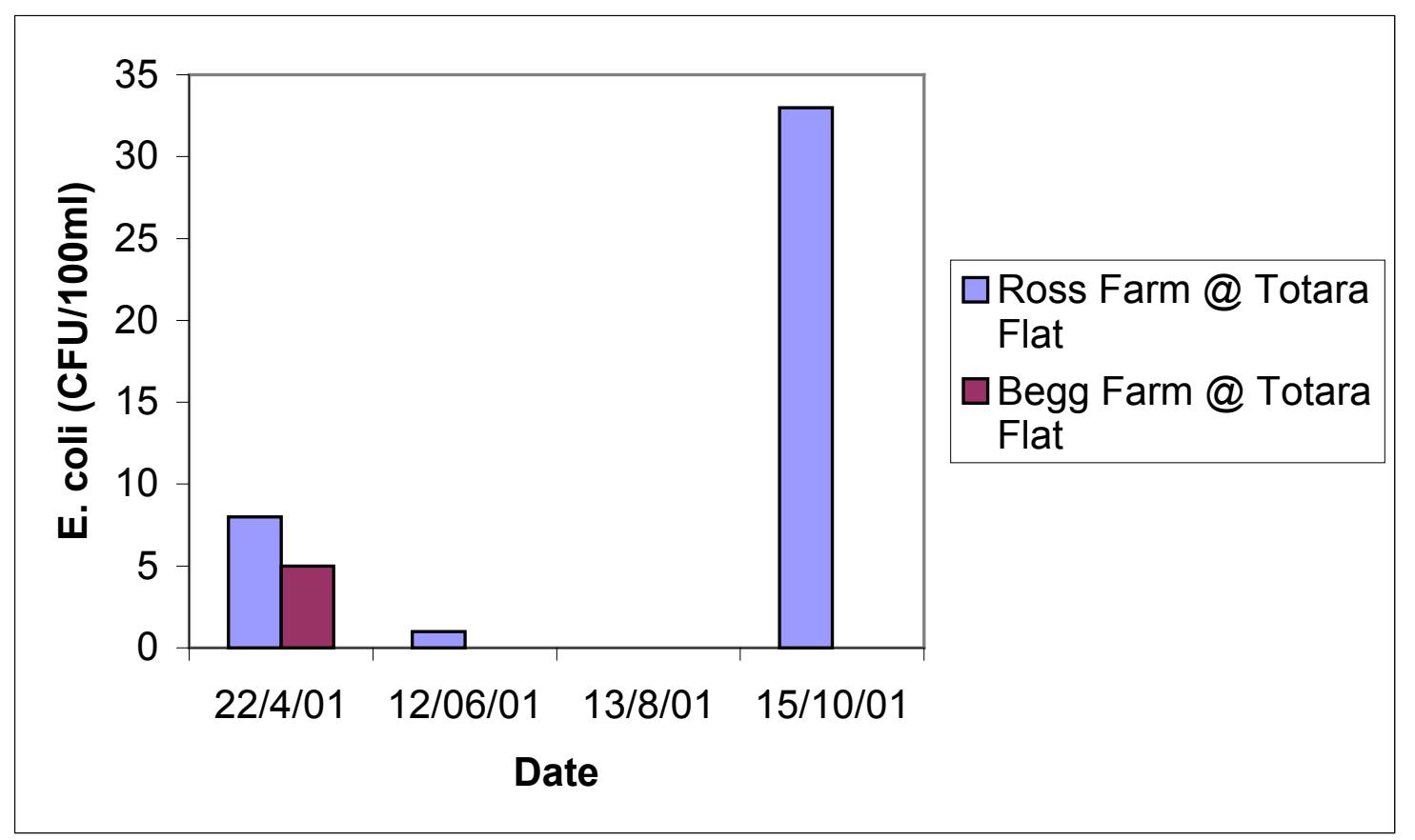

Figure 4.6: E. coli levels, Totara Flat. 


\subsubsection{4 pH, electric al conductivity and temperature}

Average $\mathrm{pH}$ values for the Totara Flat area were all below the $\mathrm{MoH}$ drinking water guidelines of $7.0-8.5$, ranging from 5.8 to 6.3 . The standard deviation on all bores was low with all values between 0.2 and 0.4 .

\begin{tabular}{l|c|c} 
Bore & pH & EC $(\mu \mathbf{S} / \mathbf{c m})$ \\
\hline Brookshaws Res @ Totara Flat & $6.1(0.2)$ & $113.1(32.4)$ \\
\hline Ross Farm @ Totara Flat & $5.9(0.2)$ & $131.0(47.3)$ \\
\hline Begg Farm @ Totara Flat & $5.8(0.4)$ & $179.0(54.2)$ \\
\hline Wilson Res @ Totara Flat & $6.2(0.3)$ & $121.9(53.7)$ \\
\hline Burnett Farm @ Totara Flat & $5.9(0.4)$ & $110.7(33.3)$ \\
\hline Hart Farm @ Totara Flat & $6.3(0.3)$ & $119.5(42.3)$ \\
\hline Havill Farm @ Ikamatua & $6.1(0.3)$ & $168.5(66.5)$ \\
\hline Beggs Farm \#2 @ Totara Flat & $5.9(0.3)$ & $129.2(41.5)$
\end{tabular}

Table 4-8: Mean (std dev) pH and EC, Ahaura Valley. Shaded cells do not meet MoH drinking water standards (2001).

Average electrical conductivity values varied less in the Totara Flat area than in the Ahaura Valley with values ranging from $110.7 \mu \mathrm{S} / \mathrm{cm}$ to $179.0 \mu \mathrm{S} / \mathrm{cm}$. However, the intra-site standard deviation of these values was high varying from $32.4 \mu \mathrm{S} / \mathrm{cm}$ to $66.5 \mu \mathrm{S} / \mathrm{cm}$.

Average temperature values showed little difference between bores and only a small standard deviation at each site of between $1.2^{\circ} \mathrm{C}$ and $3.0^{\circ} \mathrm{C}$ (Table $4-9$ ). 


\begin{tabular}{l|c|c} 
Bore & Temp. $\left({ }^{\circ} \mathbf{C}\right)$ & DO (\%) \\
\hline Brookshaws Res @ Totara Flat & $11.0(3.0)$ & $58.8(22.3)$ \\
\hline Ross Farm @ Totara Flat & $11.9(1.9)$ & $45.8(9.6)$ \\
\hline Begg Farm @ Totara Flat & $12.8(1.8)$ & $51.2(27.0)$ \\
\hline Wilson Res @ Totara Flat & $11.4(2.2)$ & $42.7(12.1)$ \\
\hline Burnett Farm @ Totara Flat & $13.3(1.8)$ & $52.2(24.2)$ \\
\hline Hart Farm @ Totara Flat & $12.2(2.5)$ & $38.2(5.2)$ \\
\hline Havill Farm @ Ikamatua & $12.7(2.2)$ & $57.4(7.0)$ \\
\hline Beggs Farm \#2 @ Totara Flat & $12.7(1.2)$ & $35.7(6.2)$
\end{tabular}

Table 4-9: Mean (std dev) temperature and dissolved oxygen, Totara Flat.

Dissolved oxygen levels ranged from $35.7 \%$ to $58.8 \%$ with standard deviations generally below $12.0 \%$. The three bores that had the highest average values also had high standard deviations above $22.0 \%$.

\subsubsection{Kowhitirangi Water Quality}

\subsubsection{Nitrate Concentrations}

The Kowhitirangi area had the lowest average nitrate concentrations of all of the study areas (Figure 4.7). The highest value recorded during the winter months was $1.3 \mathrm{~g} / \mathrm{m}^{3}$ and the lowest value was $0.3 \mathrm{~g} / \mathrm{m}^{3}$. 


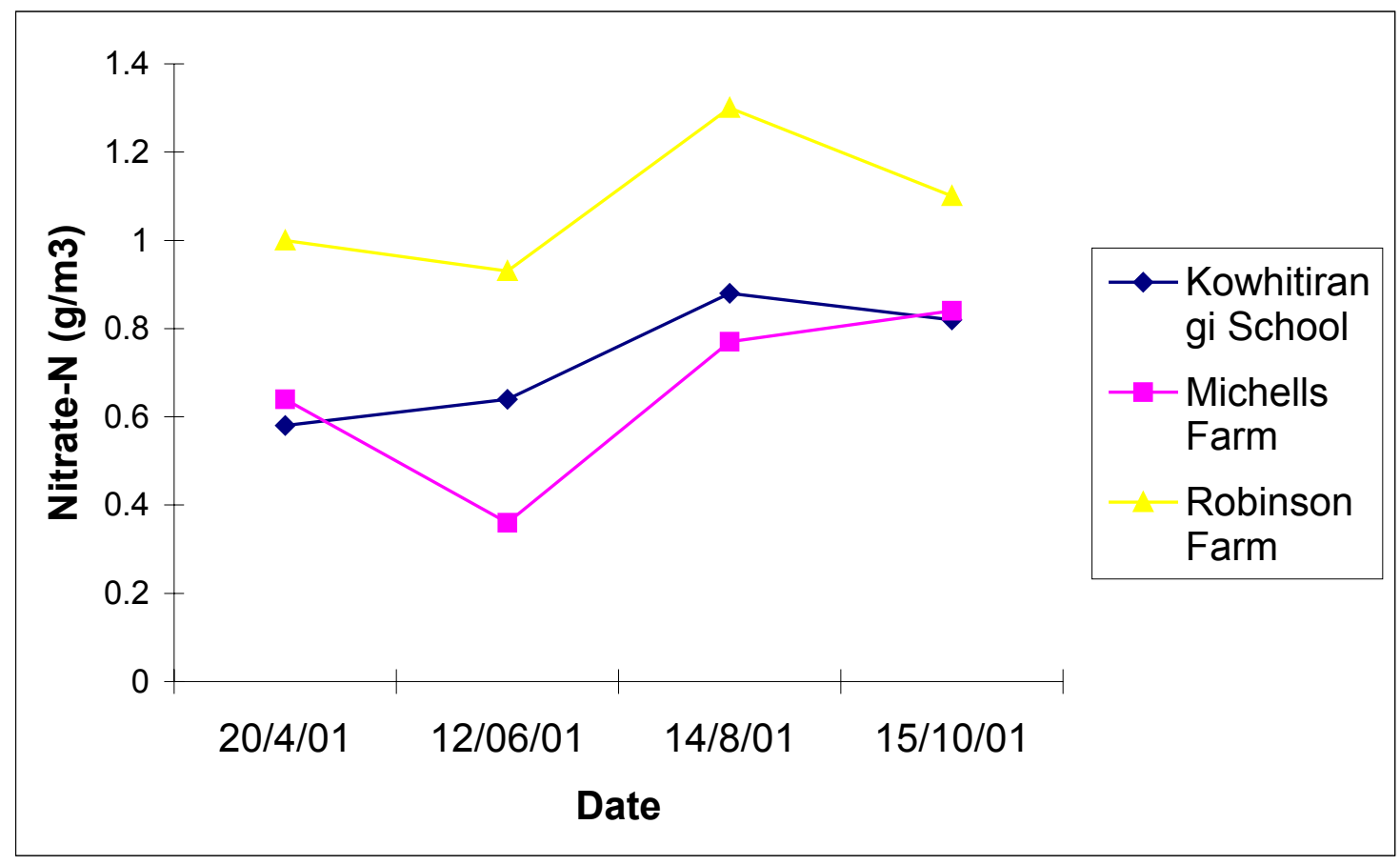

Figure 4.7:Nitrate concentrations, Kowhitirangi.

Despite the low values, the same seasonal winter increase observed at other sites was observed at Kowhitirangi. Concentrations remained well below both the $\mathrm{MoH}$ drinking water standards and the ANZECC guidelines.

\subsubsection{Ion and Nutrient Concentrations}

Dissolved reactive phosphorus levels were low and ranged from $0.009 \mathrm{~g} / \mathrm{m}^{3}$ to 0.14 $\mathrm{g} / \mathrm{m}^{3}$ (Table 4-10). Average chloride levels showed only little variation between bores, varying from $3.13 \mathrm{~g} / \mathrm{m}^{3}$ to $3.60 \mathrm{~g} / \mathrm{m}^{3}$. Ammonium levels were also well below guideline values, ranging from $0.02 \mathrm{~g} / \mathrm{m}^{3}$ to $0.06 \mathrm{~g} / \mathrm{m}^{3}$.

\begin{tabular}{l|c|c|c|c} 
Bore & $\begin{array}{c}\text { DRP } \\
\mathbf{( g / \mathbf { m } ^ { 3 } )}\end{array}$ & $\begin{array}{c}\mathbf{I R O N} \\
\mathbf{( g / \mathbf { m } ^ { 3 }}\end{array}$ & $\begin{array}{c}\mathbf{C l} \\
\mathbf{( g / \mathbf { m } ^ { 3 }}\end{array}$ & $\begin{array}{c}\mathbf{N H}_{4} \mathbf{- N} \\
\mathbf{( g / \mathbf { m } ^ { 3 }}\end{array}$ \\
\hline Michells Farm @ Kowhitirangi & $0.01(0.00)$ & $0.05(0.00)$ & $3.30(0.30)$ & $0.06(0.08)$ \\
\hline Robinson Farm @ Kowhitirangi & $0.01(0.00)$ & $0.12(0.00)$ & $3.67(0.21)$ & $0.02(0.01)$ \\
\hline Kowhitirangi School @ Kowhitirangi & $0.01(0.01)$ & $0.38(0.30)$ & $3.13(0.49)$ & $0.02(0.02)$
\end{tabular}

Table 4-10: Mean (std dev) ion and nutrient concentrations, Kowhitrangi. Shaded cells exceed MoH drinking water MAVs/guidelines (2000). 
Average iron levels only exceeded drinking water guidelines at one bore, Kowhitirangi School. This is not an active bore, and is only used sporadically. The flushing prior to sampling resulted in at least 10 minutes of iron stained water before the water stated to run clear (Table 4-10).

\subsubsection{Microbial Results}

Sampling of the three bores in the Kowhitirangi area showed no measurable occurrences of any faecal coliforms or E. coli during any of the sampling rounds.

\subsubsection{4 pH, electric al conductivity and temperature}

Average $\mathrm{pH}$ values in the Kowhitirangi area were all below the guideline values of 7.0 - 8.5 recommended by the Ministry of Health, ranging from 5.7 to 6.6 (Table 4-11). Standard deviations were low, between 0.1 and 0.3 . The average conductivity values ranged between $110.6 \mu \mathrm{S} / \mathrm{cm}$ and $127.6 \mu \mathrm{S} / \mathrm{cm}$ with standard deviations between $28.6 \mu \mathrm{S} / \mathrm{cm}$ and $36.3 \mu \mathrm{S} / \mathrm{cm}$.

\begin{tabular}{l|c|c} 
Bore & $\mathbf{p H}$ & $\begin{array}{c}\text { Conductivity } \\
(\mu \mathbf{S} / \mathbf{c m})\end{array}$ \\
\hline Michells Farm @ Kowhitirangi & $5.7(0.1)$ & $110.6(28.6)$ \\
\hline Robinson Farm @ Kowhitirangi & $5.6(0.3)$ & $115.8(29.2)$ \\
\hline Kowhitirangi School @ Kowhitirangi & $6.6(0.2)$ & $127.6(36.3)$
\end{tabular}

Table 4-11: Mean (std dev) pH and EC, Ahaura Valley. Shaded cells do not meet MoH drinking water MAVs/Guidelines (2001).

Temperature varied little both between sites and at each bore, with average values of between $11.8^{\circ} \mathrm{C}$ and $13.0^{\circ} \mathrm{C}$ (Table $4-12$ ). The intra-bore variation in temperature was lower than other areas, with standard deviations of between $0.3^{\circ} \mathrm{C}$ and $1.4^{\circ} \mathrm{C}$ 


\begin{tabular}{l|c|c} 
Bore & Temp. $\left({ }^{\circ} \mathbf{C}\right)$ & DO (\%) \\
\hline Michells Farm @ Kowhitirangi & $13.05(0.7)$ & $46.9(6.0)$ \\
\hline Robinson Farm @ Kowhitirangi & $11.80(1.4)$ & $45.4(9.1)$ \\
\hline Kowhitirangi School @ Kowhitirangi & $11.88(0.3)$ & $64.1(6.3)$
\end{tabular}

Table 4-12: Mean (std dev) temperature and dissolved oxygen results, Kowhitirangi.

Dissolved oxygen results for the Kowhitirangi area bores ranged from $45 \%$ to $64 \%$. The standard deviations were lower than in other areas, at between $6 \%$ and $9 \%$.

\subsubsection{Inangahua Valley}

\subsubsection{Nitrate Con centrations}

At $1.28 \mathrm{~g} / \mathrm{m}^{3}$ (standard deviation $0.31 \mathrm{~g} / \mathrm{m}^{3}$ ) the Mitchell Brothers farm bore water had low levels of nitrate-nitrogen. The Parkinson farm bore had a higher average value of $3.77 \mathrm{~g} / \mathrm{m}^{3}$ (standard deviation $2.05 \mathrm{~g} / \mathrm{m}^{3}$ )

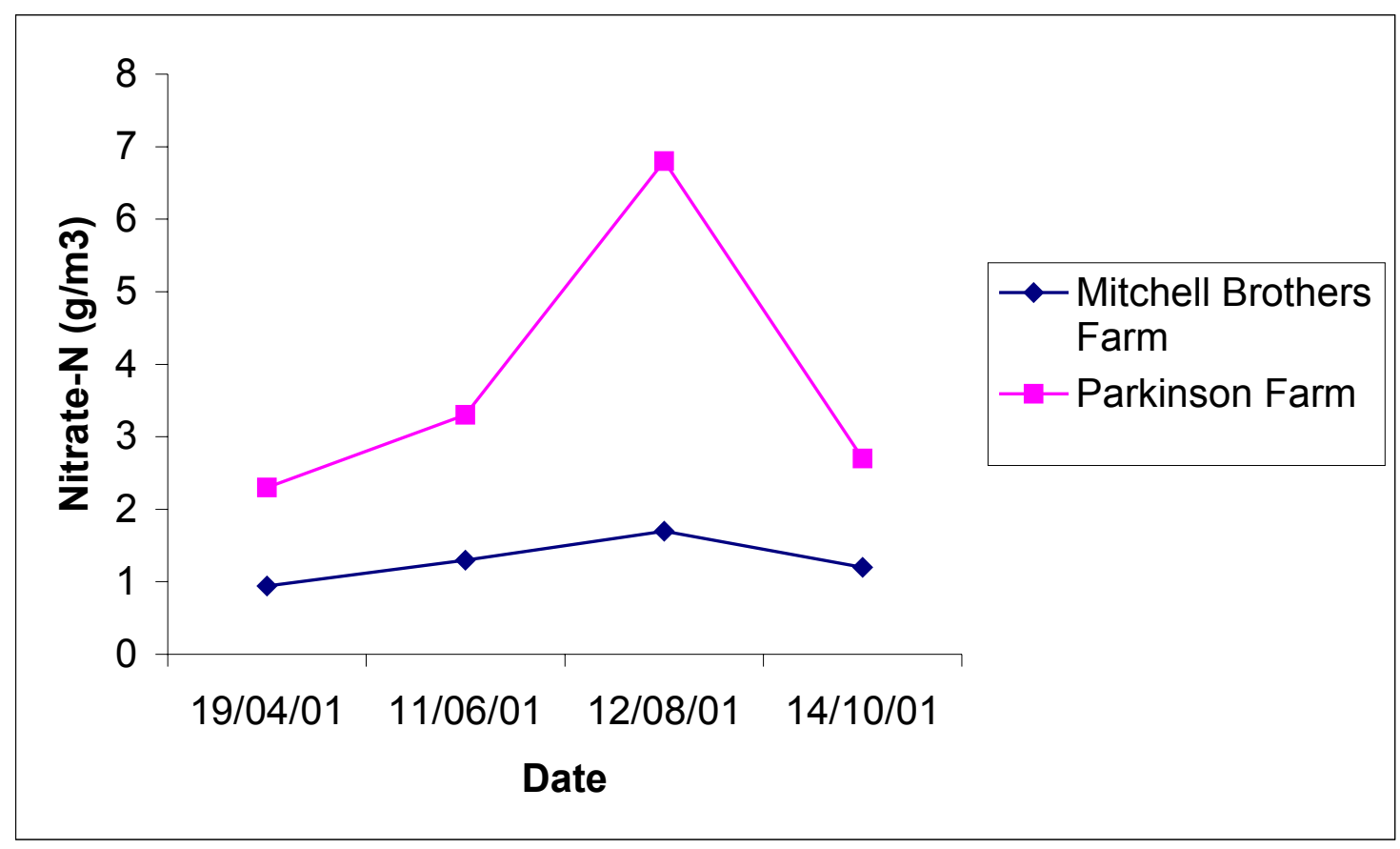

Figure 4.8: Nitrate concentrations, Inangahua Valley. 
Like the other study areas, both bores showed increases during the winter months. Water levels in these areas were shallow, averaging only $3 \mathrm{~m}$ below the surface over the study period, which, because of the shortened distance for potential contaminants to travel through the soil body, can account for the large seasonal variations.

\subsubsection{Ion and Nutrient Concentrations}

All average ion and nutrient concentrations in the Inangahua valley bores were well below guideline values (Table 4-13).

\begin{tabular}{l|c|c|c|c} 
Bore & $\begin{array}{c}\text { IRON } \\
\left(\mathbf{g} / \mathbf{m}^{\mathbf{3}}\right)\end{array}$ & $\begin{array}{c}\text { DRP } \\
\mathbf{( g / \mathbf { m } ^ { 3 } )}\end{array}$ & $\begin{array}{c}\mathbf{C l} \\
\mathbf{( g / \mathbf { m } ^ { 3 }}\end{array}$ & $\begin{array}{c}\mathbf{N H}_{\mathbf{4}} \mathbf{- N} \\
\mathbf{( g / \mathbf { m } ^ { 3 }}\end{array}$ \\
\hline Mitchell Bros Farm @ Cronadun & $0.05(0.00)$ & $0.01(0.00)$ & $7.10(1.35)$ & $0.02(0.02)$ \\
\hline Parkinson Farm @ Reefton & $0.01(0.00)$ & $0.01(0.00)$ & $5.30(1.56)$ & $0.01(0.01)$
\end{tabular}

Table 4-13: Mean (std dev) ion and nutrient results, Inangahua Valley.

\subsubsection{Microbial Results}

Results of microbial testing of both Parkinsons farm and the Mitchell Brothers farm bore water showed no measurable levels of either Faecal Coliforms or E. coli.

\subsubsection{4 pH, electrical conductivity and temperature}

$\mathrm{pH}$ levels in the Inangahua valley were consistent with the other West Coast areas and were below drinking water guidelines set by the Ministry of Health. Also like other areas, the standard deviation of these $\mathrm{pH}$ results was low (Table 4-14).

\begin{tabular}{l|l|l} 
Bore & pH & Conductivity $(\mu \mathbf{S} / \mathbf{c m})$ \\
\hline Mitchell Bros Farm @ Cronadun & $6.15(0.7)$ & $116.80(58.9)$ \\
\hline Parkinson Farm @ Reefton & $6.05(0.8)$ & $127.10(102.3)$
\end{tabular}

Table 4-14: Mean (std dev) pH and conductivity, Inangahua Valley. Shaded cells do not meet MoH drinking water standards (2001). 
Conductivity results showed considerable variation, with an average measurement on the Parkinson farm bore of $127.1 \mu \mathrm{S} / \mathrm{cm}$ and a standard deviation of $102.3 \mu \mathrm{S} / \mathrm{cm}$ (Table 4-14). Conductivity values are generally stable in groundwater and so a deviation of this size warrants further investigation.

\begin{tabular}{l|c|c|} 
Bore & Temp. $\left({ }^{\circ} \mathrm{C}\right)$ & Do (\%) \\
\hline Mitchell Bros Farm @ Cronadun & $13.2(1.9)$ & $44.1(7.4)$ \\
\hline Parkinson Farm @ Reefton & $12.2(3.1)$ & $67.3(16.7)$
\end{tabular}

Table 4-15: Mean (std dev) temperature and dissolved oxygen results, Inangahua Valley

Samples from the Parkinson farm bore showed some variation in temperature and dissolved oxygen levels. Average temperature was $12.2^{\circ} \mathrm{C}$ (standard deviation $3.1^{\circ} \mathrm{C}$ ) and the average dissolved oxygen level was $67.3 \%$ (standard deviation of $16.7 \%$ ). 


\subsubsection{Regional Trends}

While the above results focus on patterns and trends in the individual areas of the West Coast, the compilation of this data reveals interesting relationships for the whole West Coast region.

The relationship between nitrate-nitrogen and chloride is a useful analysis because if effluent sources, either agricultural or human, were the source of nitrate contamination then a positive relationship would be expected between these two determinants (Figure 4.9). This is because the presence of elevated levels of chloride is a good indication of sewage contamination (Rosen, 2001b) due to the high levels of salts in human and animal effluent.

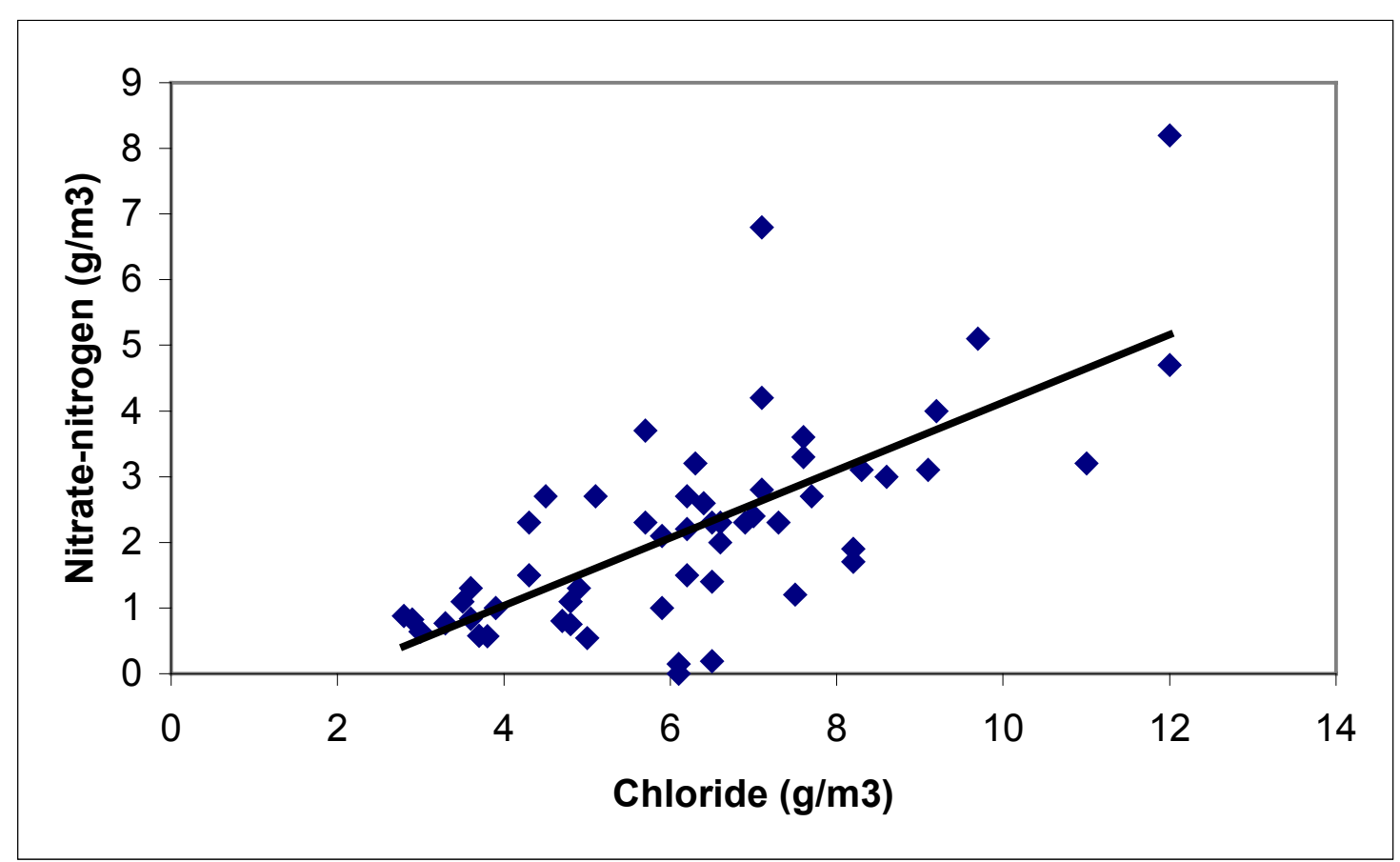

Figure 4.9: Nitrate-N and chloride levels, West Coast Region (each point is the instantaneous value from the four sampling rounds, a total of 76 samples)

Over the region the chloride concentration $\left(\mathrm{g} / \mathrm{m}^{3}\right)$ explains $51 \%$ of the variance in nitrate-nitrogen concentration and the slope of the regression line (0.714) was significantly different $(P$ value $=0.00$ ) from 0 (SPSS, 2000). 


\subsubsection{Variations in nitrate-nitrogen concentrations with depth}

Where access and bore head construction allowed, measurements of water level were taken at the time of sampling. Several studies have shown that groundwater nitrate-nitrogen concentrations decrease with depth to the water table (Freeze and Cherry, 1979; Close et al., 2001). In many confined aquifers this occurs because oxidation potential decreases with depth, and nitrate is reduced to nitrogen gas or ammonia. In other cases it may be a result of nitrates not yet having reached the deeper water.

When investigating trends of nitrate-nitrogen with depth it is important to take note that the depth of the groundwater can be considered in three different ways (Hanson, 2002). The depth of the water table below the ground surface can influence the attenuation of the nitrate concentrations in the soil drainage that reaches the groundwater. Nitrate is a conservative contaminant that does not decay in the unsaturated zone and is not adsorbed by the sediment (Freeze and Cherry, 1979; Close et al., 2001). Dairy shed effluent applied to land is a mix of organic and inorganic nitrogen and usually contains no nitrate (rather it is applied as $\mathrm{NH}_{4}-\mathrm{N}$ and organic N). Ammonium is converted to nitrate during time in the soil. Thus the depth to the water table is an indication of the time over which this conversion can occur. The effects of a deeper water table would be to reduce the peak concentrations and size of the seasonal variations in nitrate, rather than decreasing the amount of nitrate reaching the groundwater (Hanson, 2002).

The depth of the screen (where the water from the groundwater system actually enters the bore) below the water table can affect the nitrate concentrations in a bore because of the dilution that occurs as the drainage water mixes with the groundwater. The higher the screen is set the sooner it will intercept drainage water.

The total depth of the bore below ground level (a combination of the above two factors) does not directly affect nitrate concentrations; however, it is the most commonly recorded feature. 
Detailed information on screen depths was not available for any of the bores used in this study which limits the analysis possible in relation to nitrate-nitrogen concentration with depth. However, all of the bores monitored had information on the total depth of the bore available, and at most sites water levels were taken at the time of sampling. Nitrate-nitrogen concentrations versus water level are plotted for the shallow unconfined bores of the Totara Flat, Kowhitirangi and Reefton Areas (Figure 4.10), and for the deeper unconfined bores of the Ahaura Valley (Figure 4.11).

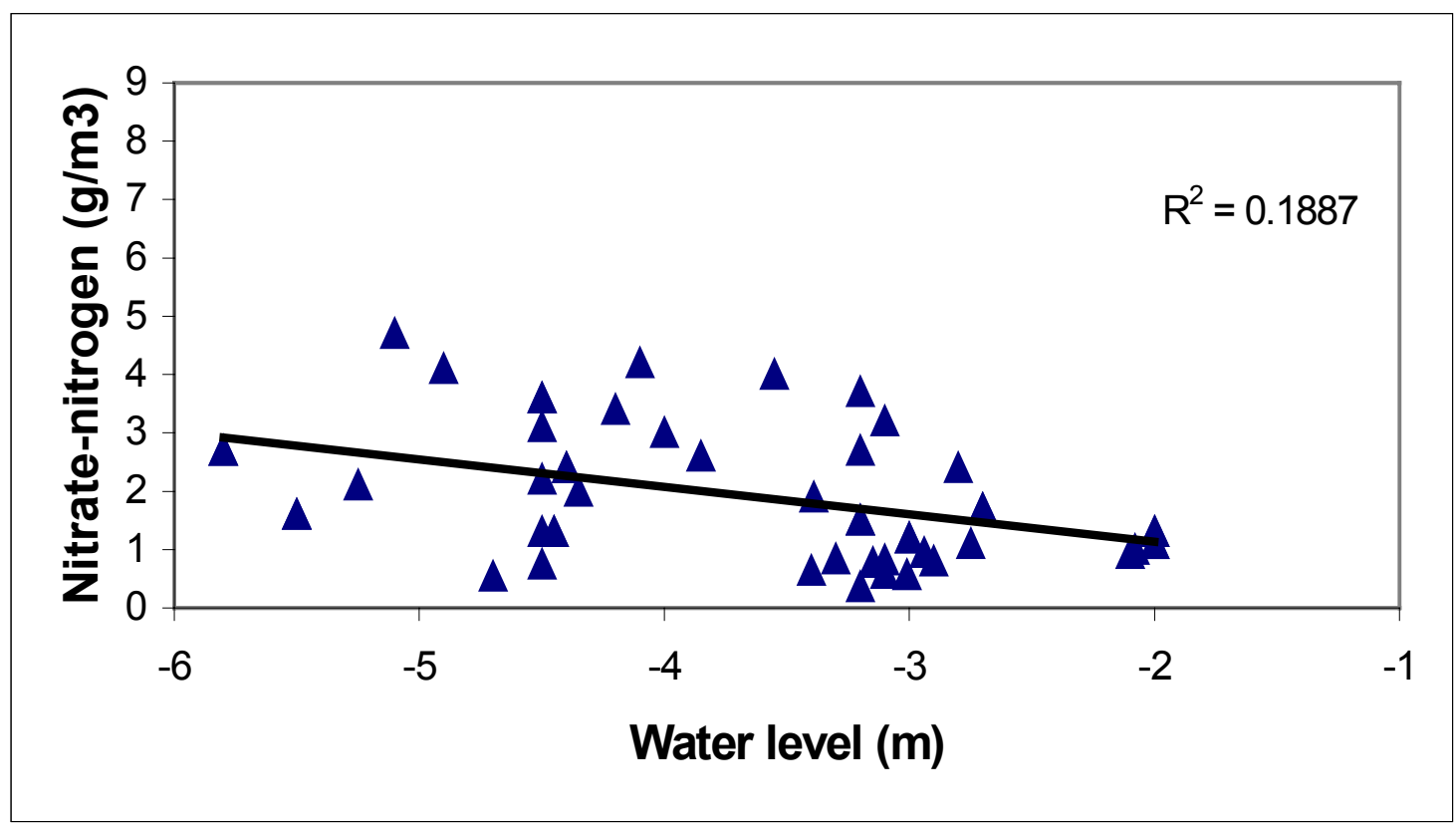

Figure 4.10: Variation of nitrate-nitrogen levels with water depth in shallow unconfined bores

Only a weak correlation $(r=0.43)$ was observed between nitrate-nitrogen and water level for the shallow unconfined bores of the Totara Flat, Kowhitirangi and Reefton Areas. The bores in the Ahaura Valley area are all deeper and are compared separately (Figure 4.11). 


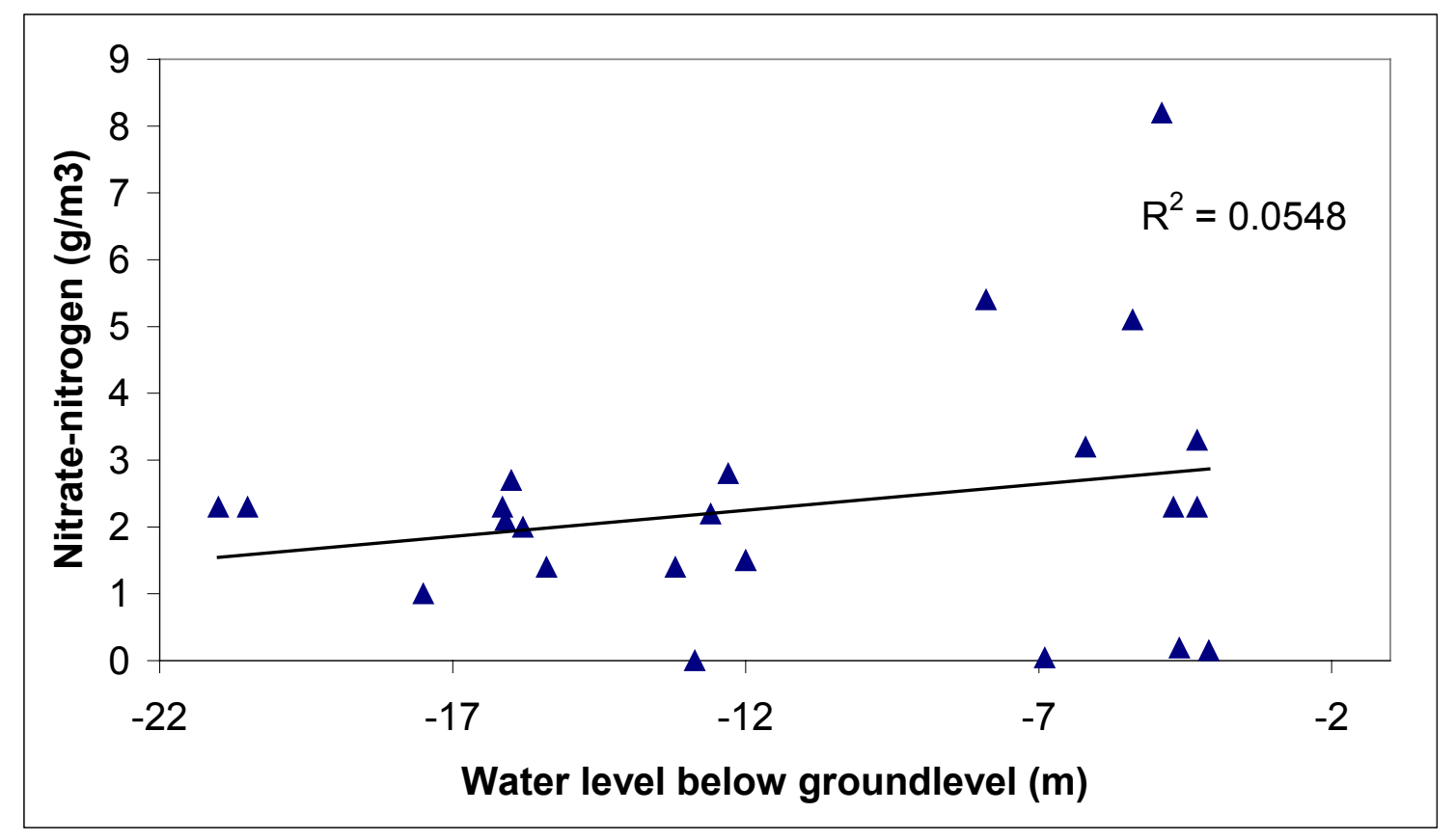

Figure 4.11: Variation of nitrate-nitrogen with water level below ground surface in deep unconfined bores

Comparison of water levels and nitrate-nitrogen levels in the deeper unconfined bores of the Ahaura Valley also showed only a weak correlation, although the highest concentrations in the valley were located where the water levels were less than $10 \mathrm{~m}$ deep. More variable results were also recorded in the shallow bores. The slope of the line was positive in Figure 4.10 unlike Figure 4.11 which was negative. The slope of the line in the case of Figure 4.11 seems to be controlled by a few high nitrate values at water levels around $-5 \mathrm{~m}$ deep.

For comparison, mean nitrate levels are plotted against total bore depth in (Figure 4.12). In most cases the bores are not screened, however, in those that are screened, the screen is located at the bottom of the bore. 


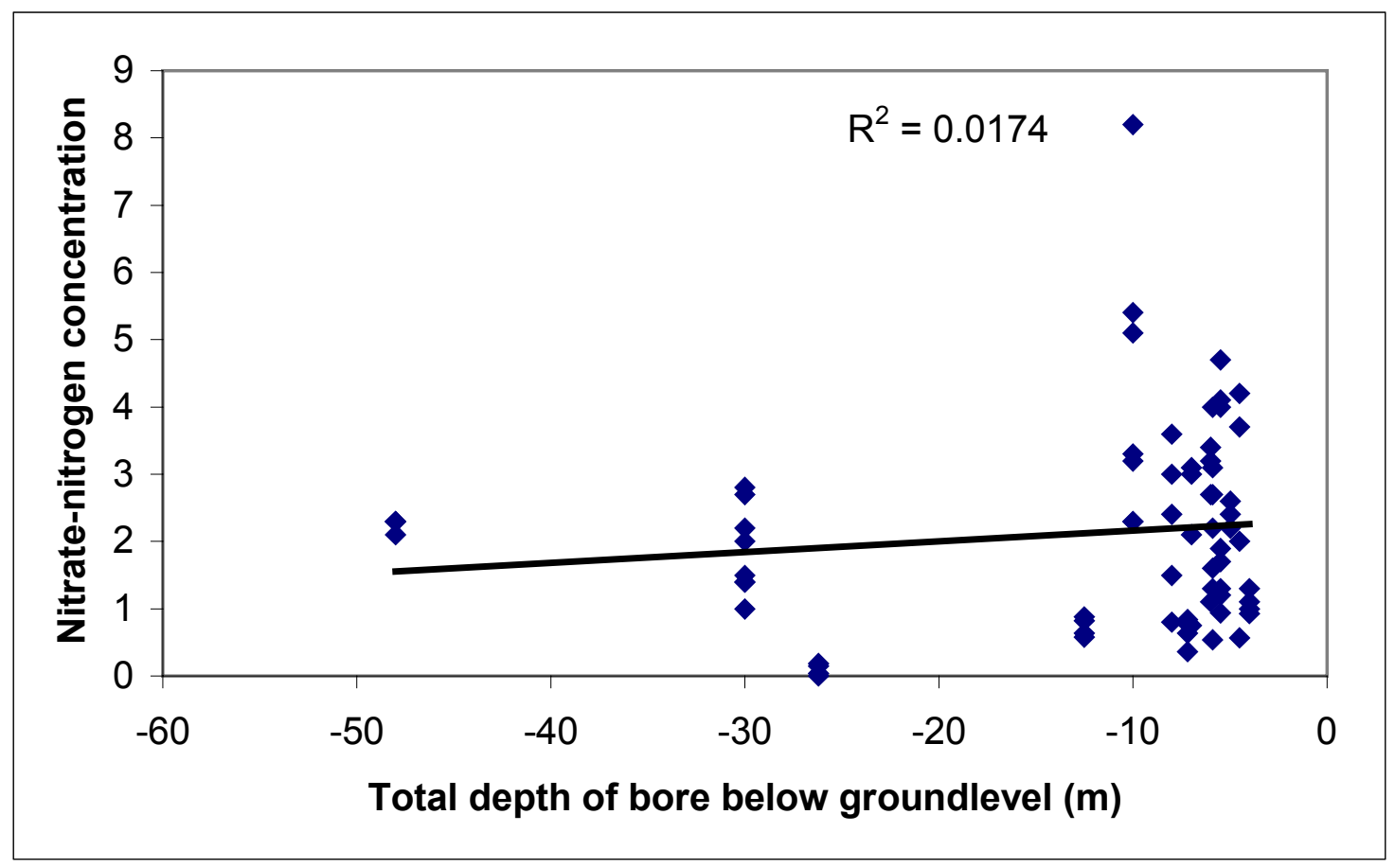

Figure 4.12: Nitrate-nitrogen concentration versus bore depth below ground surface (total of 76 samples from all study bores).

Comparison of total bore depths with nitrate-nitrogen comparisons showed little correlation overall, however, the scatter of the datapoints changes markedly with depth. There is much greater variation in nitrate values in the shallower bores than in the deeper bores, possibly an indication of the seasonality associated with shallow groundwater systems. However, there are several limitations with this graph. It does not take into account the depth of any screen present in the bore or the size of any screen that may be in the bore. However, as discussed above, where screens were present in the study bores, they were located at the bottom of the bore but their size is unknown. Also, grouping the different locations of sampling together may affect the relationship between nitrate and depth. However, from the graph it should be noted that concentrations of nitrate-nitrogen greater than $3 \mathrm{~g} / \mathrm{m}^{3}$ were only present in wells shallower than $10 \mathrm{~m}$. 


\subsubsection{NGMP Results}

In addition to the nineteen bores sampled for this study, results from three National Groundwater Monitoring Programme (NGMP) bores were obtained from GNS for use in this study. Using this data allows the data from the nineteen study bores to be compared with a long-term dataset. Results from 1998 - 2000 were discussed briefly in the earlier part of this chapter to give some background information on groundwater water quality. This section is more comprehensive and uses data obtained after the initial study period.

In total there are seven sites on the West Coast that have been monitored as part of the NGMP. For the purposes of this study, data from three bores, Bertacco, Coleman (Lyndale) and Anderson are used. The Anderson bore at Kowhitirangi is no longer monitored as part of the NGMP because of an access issue; however, data from this bore between September 1998 and September 2001 is used. For the Bertacco and Coleman bores the dataset runs from September 1998 to October 2003.

The Bertacco farm is located on the Ahaura plains, one of the most intensive dairying areas in the Grey Valley, and is down gradient of the five Ahaura Valley sites chosen for this project. In the Kowhitirangi area there are two NGMP sites. The Coleman (Lyndale) farm bore and Anderson's farm bore. The Coleman (Lyndale) farm is situated down gradient of the most intensively farmed part of the Kowhitirangi flats while Anderson's farm is located upgradient of this area.

\subsubsection{Methods}

Long term trends in the NGMP data was investigated using a Mann-Kendall trend analysis, a non-parametric test that does not depend on the data being drawn at random from a normally-distributed population (Gilbert, 1987). The Mann-Kendall test does not calculate the magnitude of the trend; It only determines whether or not a trend is present.

For wells where a trend is identified, the magnitude of the trend was estimated using Sen's slope estimator, a non-parametric test that is less affected by data errors, 
outliers or missing data than a simple linear regression (Gilbert, 1987). In addition, linear regressions were calculated for comparison.

\subsubsection{Results}

Graphs and trend analysis of nitrate-nitrogen and chloride are given for the Bertacco, Coleman and Anderson bores. Other analytes were available for analysis but nitratenitrogen and chloride were chosen because of their association with effluents and the results previously shown. Results of all analytes for all of the NGMP bores are given in Appendix 3.

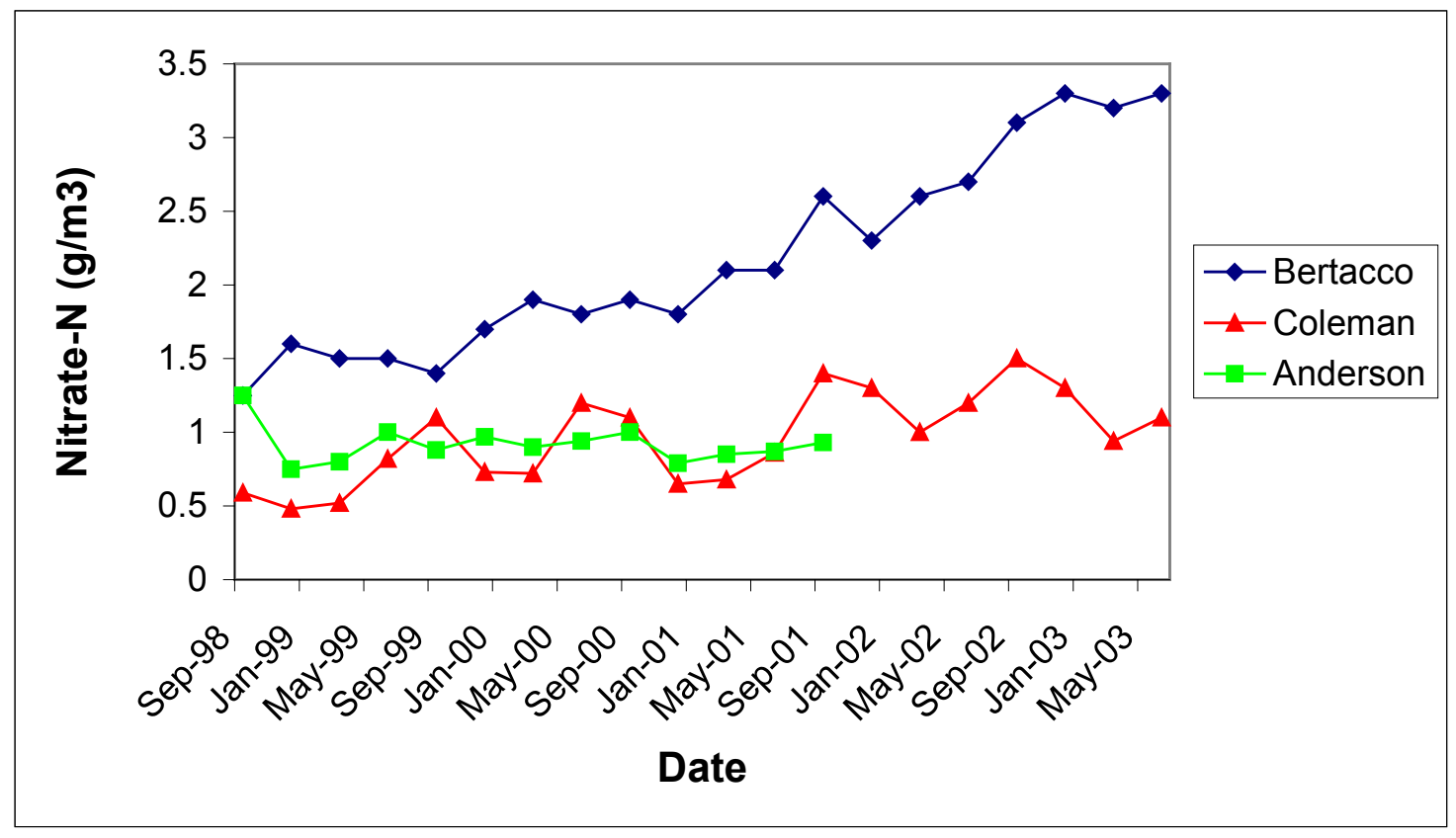

Figure 4.13: Nitrate-nitrogen levels of West Coast NGMP bores Sep 1998 - Sep 2003; data: GNS, 2004.

Nitrate nitrogen levels in both the Bertacco and Coleman bores have shown a steady increase over the term of the monitoring programme (1998-2003). Seasonal peaks are evident in Figure 4.13 with peak nitrate levels occuring during the spring months (Aug/Sep). The Anderson bore, with its shorter data record, shows no apparent trends in nitrate levels; however, this bore is also located upgradient of most dairy farms in the area and therefore lower and less variable nitrate trends were expected. 
Trend analysis of the nitrate-nitrogen levels in the NGMP bores is shown in Table 4-16. Increasing trends of nitrate-nitrogen were identified in both the Bertacco and Coleman bores. No trend was apparent in the Anderson bore.

\begin{tabular}{l|l|l|l} 
& Bertacco & Coleman & Anderson \\
\hline \# Samples & 20 & 20 & 13 \\
\hline MK Stat & 160 & 89 & -5 \\
\hline Trend & Increase & Increase & No \\
\hline Sens's Slope $\left(\mathrm{g} / \mathrm{m}^{3} / \mathrm{y}\right)$ & 0.41 & 0.13 & -0.01 \\
\hline Linear Regression $\left(\mathrm{g} / \mathrm{m}^{3} / \mathrm{y}\right)$ & 0.51 & 0.11 & -0.03
\end{tabular}

Table 4-16: West Coast NGMP bore trend statistics of nitrate-nitrogen levels (at $95 \%$ confidence interval)

There was generally a good agreement between the Sen's slope estimator and the linear regression slope (Table 4-16). The magnitudes of slopes varied between sites with Bertacco showing the strongest increase of $0.41 \mathrm{~g} / \mathrm{m}^{3}$ per year and Coleman showed an increase of $0.13 \mathrm{~g} / \mathrm{m}^{3}$ per year. That is, at both Bertacco and Coleman bores there has been a significant trend of increasing nitrate levels.

Chloride levels in both the Bertacco and Coleman bores showed increases over the five year monitoring period. Seasonal peaks are apparent in both bores; however, the peaks do not occur during the same months at each bore. This is possibly an indication of the difference between the bores in the travel times for contaminants to reach the water table (the distance from groundlevel to the water table is less than $3 \mathrm{~m}$ at the Coleman bore and greater than $5 \mathrm{~m}$ in the Bertacco bore). The Anderson bore shows no significant changes in chloride over the study period. 


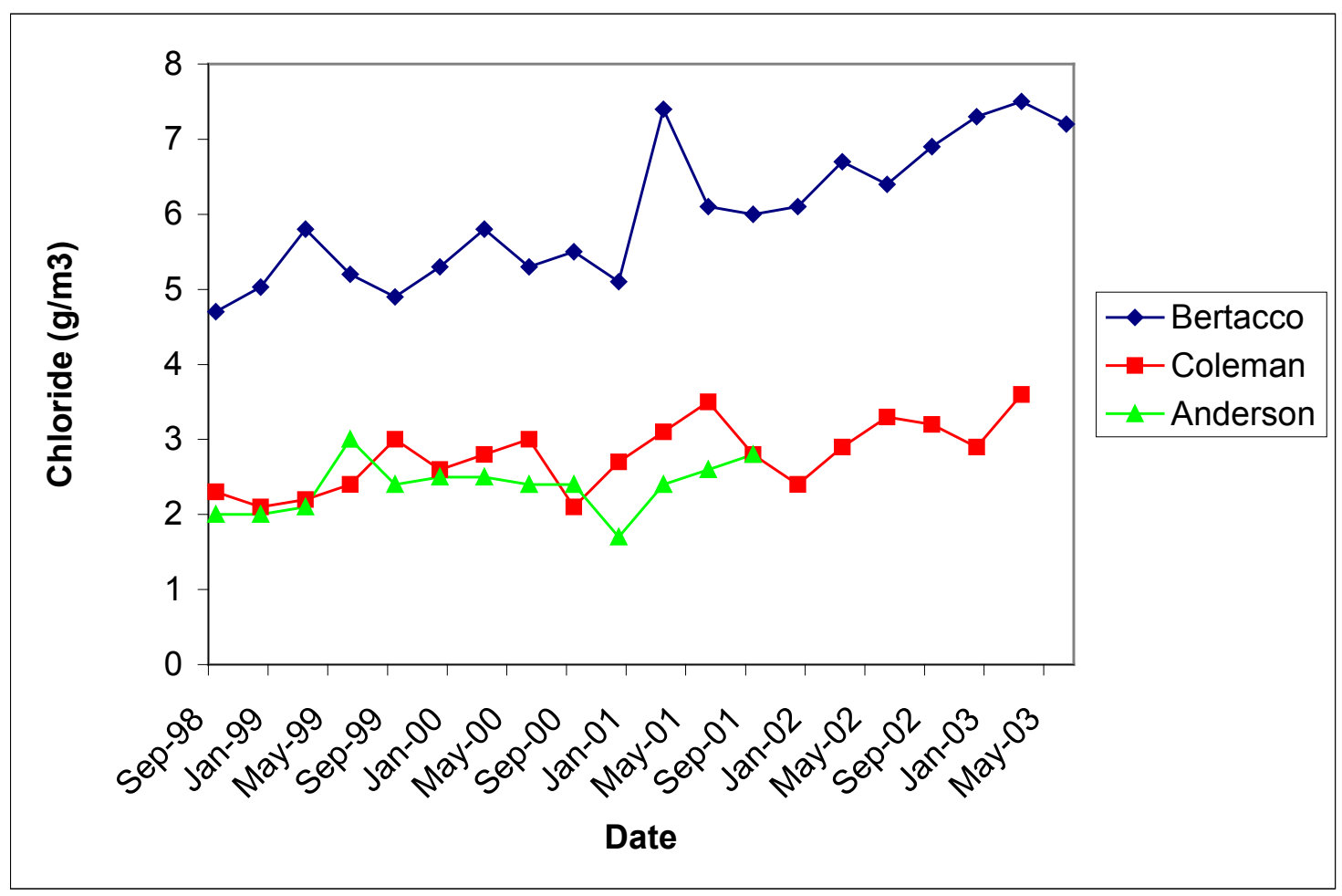

Figure 4.14: Chloride levels of West Coast NGMP bores Sep 1998 - Sep 2003; data: GNS, 2004.

Trend analysis of Chloride levels in the NGMP bores shows significant increasing trends at both the Bertacco bore and the Coleman bore. No apparent trend was evident in the Anderson bore at the 95\% confidence level (Table 4-17); however, at the $80 \%$ confidence level an increasing trend was apparent.

\begin{tabular}{l|l|l|l} 
& Bertacco & Coleman & Anderson \\
\hline \# Samples & 20 & 20 & 13 \\
\hline MK Stat & 129 & 100 & 24 \\
\hline Trend & Increase & Increase & No \\
\hline Sens's Slope $\left(\mathrm{g} / \mathrm{m}^{3} / \mathrm{y}\right)$ & 0.50 & 0.22 & 0.19 \\
\hline Linear Regression $\left(\mathrm{g} / \mathrm{m}^{3} / \mathrm{y}\right)$ & 0.39 & 0.19 & 0.15
\end{tabular}

Table 4-17: West Coast NGMP bore trend statistics of Chloride levels

The relationship between Sen's slope estimator and the linear regression was similar to that seen for nitrate-nitrogen levels in the Coleman and Bertacco bores. Both the Bertacco and Coleman bores showed significant increasing trends in chloride 
concentrations with the Sen's slope estimations at $0.50 \mathrm{~g} / \mathrm{m}^{3}$ per year $0.22 \mathrm{~g} / \mathrm{m}^{3}$ per year respectively.

\subsection{DISCUSSION}

The results from each of the four main study areas are first discussed to give a summary of the groundwater quality in each area. Trends, patterns and issues relevant to the whole region are then discussed.

\subsubsection{Ahaura valley}

The highest nitrate-nitrogen concentrations recorded from the 19 study bores and the NGMP bores were recorded in the Ahaura valley. The spatial distribution of the sampled bores up the valley allows investigation of possible cumulative down gradient groundwater contamination. The valleys position on a high river terrace above the Grey and Ahaura rivers (Figure 1.15) results in groundwater levels being deeper than in other areas. Bores in the top of the valley are typically 30-50m deep with groundwater levels being $7 \mathrm{~m}$ and $20 \mathrm{~m}$ below the ground surface. Mears (pers. comm., 2002) suggests the unconfined aquifer on the raised terrace of the Ahaura valley, which all of the bores studied tap, is predominantly rainfall recharged and that the large fluctuations in groundwater levels seen reflect this. The low transmissivities outlined in Chapter Three (Table 3.1) also suggest the dominance of rainfall recharge. Lower in the valley, at the Bertacco, Bull and Mills bores, the depth to the water table was shallower at between $4 \mathrm{~m}$ and $7 \mathrm{~m}$ deep.

According to the WCRC Dairy Effluent database (1998), all nine of the dairy farms in the Ahaura Valley apply their dairy shed effluent to land. Of the farms visited for this study, six of them used a traveling irrigator, and one farm uses a vehicle spreader. Compared with the Totara Flat, Inangahua Valley and Kowhitirangi areas, the number of farms applying their effluent to land in the Ahaura valley is much higher. Combined with the highest stocking rates in the region (LIC, 2003) at 2.3 cows/ha, the Ahaura valley has the most potential of the four study areas for nutrient leaching. 
The median nitrate-nitrogen concentration over all of the Ahaura Valley study bores, and at the Bertacco NGMP bore, was $2.15 \mathrm{~g} / \mathrm{m}^{3}$ for the study period. At the head of the valley the Coleman bore had the lowest levels of nitrate-nitrogen. Apart from the Johnson bore, all bores in the Ahaura valley had nitrate-nitrogen concentrations greater than $1 \mathrm{~g} / \mathrm{m}^{3}$. The Johnson bore had the lowest levels of nitrate-nitrogen in the valley with a median value of $0.15 \mathrm{~g} / \mathrm{m}^{3}$. In general, the lower concentrations were recorded at the head of the valley, and the highest concentrations near the bottom of the valley, such as at the Mills bore. Trend analysis on the Bertacco NGMP bore, located at the bottom of the valley (Figure 2-15), showed a significant increasing trend in nitrate-nitrogen of over $0.5 \mathrm{~g} / \mathrm{m}^{3} / \mathrm{year}^{-1}$. At over $1 \mathrm{~g} / \mathrm{m}^{3}$, the nitrate-nitrogen concentrations in the Ahaura valley suggest that there is some degree on anthropogenic influence on the groundwater quality in this area. Nitrogen Isotope analysis in Chapter 5: Age Dating and Isotope Analysis will help to determine the source of the elevated nitrate levels.

The median chloride concentration over all the samples from the Ahaura valley during the study period was $6.4 \mathrm{~g} / \mathrm{m}^{3}$. While this is below the drinking water guidelines, the concentration measured, and the increasing chloride concentration from the Bertacco bore suggests that all bores in the valley have elevated and increasing chloride concentrations. Coupled with the elevated nitrate-nitrogen levels, the elevated chloride levels detected in the all of the bores in the Ahaura Valley suggest that there is some effluent-sourced contamination entering the groundwater (Freeze and Cherry, 1979).

The higher concentrations of nitrate-nitrogen and chloride in the Ahaura valley may also be a reflection of the dominance of rainfall recharge on the groundwater, the high rainfall and coarse river gravels. As opposed to river-recharge dominated water, rainfall-recharge dominated water all passes through the soil and unsaturated zone potentially leaching nutrients and major ions.

Both the Bray and Johnson bores had mean iron concentrations above the MoH New Zealand Drinking Water Standards (2000). The Johnson bore had the highest concentration of iron in the valley (median $=1.96 \mathrm{~g} / \mathrm{m}^{3}$, mean $=3.37 \mathrm{~g} / \mathrm{m}^{3}$ ). The Johnson bore also had low concentrations of nitrate-nitrogen. Under reducing 
conditions nitrate-nitrogen is converted to nitrogen gas or ammonium through denitrification (Freeze and Cherry, 1979). Reduced waters are typified by high iron and manganese, low dissolved oxygen and elevated $\mathrm{NH}_{4}$; however, manganese was not tested for in this study. A simple test of the reduction/oxidation (Redox) potential of groundwater is where concentrations of ammonium exceed that of nitrate-nitrogen (Rosen, 2001b). Using this test on the Johnson bore would suggest that reducing conditions are not occurring in this aquifer. However, low concentrations of dissolved oxygen and elevated iron were recorded which indicate reducing conditions, which could explain the low concentrations of nitrate-nitrogen in the bore.

Results from the microbial testing showed sporadic occurrences of microbial contamination in the Ahaura valley. An E. coli count of $5 \mathrm{cfu} / 100 \mathrm{ml}$ was recorded from the Galligan bore sample collected during the April sampling round. Following this, the Galligan bore was found to be located next to an open offal pit which had been used several weeks prior to sampling (Galligan, pers comm., 2001). It is likely that contamination had leached from this pit into the bore. An E. coli count of 40 $\mathrm{cfu} / 100 \mathrm{ml}$ was observed in the Johnson bore during the October sampling round. The depth to groundwater was at is shallowest during this sampling round following the winter rainfall. It is possible that the shorter flow path from the surface to the water level accounts for this high $E$. coli count.

\subsubsection{Totara Flat}

All seven of the dairy farms in the Totara Flat area indicated to the WCRC during the 1998 Dairy Effluent Survey that they applied their dairy shed effluent to land. However, during field visits, and during communication with the farmers/share milkers, it was noted that several of the properties (Burnett, Hart, Ross) in fact had oxidation pond systems that subsequently discharge to surface water. In all cases the dairy shed effluent was occasionally and irregularly pumped out the ponds and sprayed onto the pasture via a vehicle spreader. The Havill farm on the upper Ikamatua Plain was the largest dairy farm monitored during this study. Milking 520 cows, the Havill farm applies all of its effluent to land over a 60ha area, but only using 15ha per year. 
All seven of the bores on the lower river terrace at Totara Flat and the Havill bore on the high Ikamatua plain showed evidence of elevated nitrate-nitrogen and chloride levels. The mean nitrate-nitrogen level for these bores was $2.5 \mathrm{~g} / \mathrm{m}^{3}$. Unfortunately there was no NGMP bore in the area to assess long-term trends from; however, with similar water levels, hydrogeology, rainfall and landuse practices to the lower Ahaura valley sites, comparisons may be made with the increasing trends evident from the Bertacco bore.

The microbial sampling of faecal coliforms and E. coli at the Ross farm bore identified $E$. coli during three of the four sampling rounds. This incidence of bacteriological contamination is of concern. The contamination was possibly sourced from a nearby farm drain into which the oxidation ponds drained (see Appendix 3: Site Details). On all four site visits the pump controlling the oxidation pond discharge was broken, which was causing effluent to run back up farm drains. This drain was located only $4 \mathrm{~m}$ from the bore head and was approximately $1.5 \mathrm{~m}$ below ground level. The water level at this bore was approximately $4 \mathrm{~m}$ below ground surface. Water from this bore supplied drinking water for two houses and stock drinking water. During the course of the study a number a calves died at this farm due to a faecal coliform related gut bacteria (McCleery pers comm., 2001)

Several properties in the Totara Flat area have previously reported health problems as a result of drinking from groundwater sources. Past residents of the Brookshaw property, which is surrounded by dairy farms (James pers comm., 2001); and share milkers on the Begg property (Begg pers comm., 2001), have had stomach bugs which they attributed to the groundwater. In the case of the Begg bore, it was suggested that heavy pumping during low summer water levels drew poor quality water through from a poorly lined oxidation pond. Thus the new bore, Begg \#2, was drilled to replace this bore (Begg pers comm., 2001).

\subsubsection{Kowhitirangi}

Low concentrations of nitrate-nitrogen were observed throughout the Kowhitirangi area. The mean nitrate-nitrogen concentration for the three study bores; Michells, Robinson and Kowhitirangi School; and the two NGMP bores; Anderson and 
Coleman (Lyndale) was $0.82 \mathrm{~g} / \mathrm{m}^{3}$. This is below the $1 \mathrm{~g} / \mathrm{m}^{3}$ level regarded as the level above which anthropogenic influence is probable (Rosen, 2001b). However, long-term trend analysis from the Colman NGMP bore shows an increasing trend in nitrate-nitrogen levels between 1998 and 2003. While low, the increasing trend in nitrate-nitrogen suggests that some leaching of nutrients from dairy farming practices is occurring.

Measuring the ammonium levels present in the groundwater is important when assessing the impact of nitrogen leaching as this form of nitrogen represents recent contamination where the ammonium has yet to be oxidised to $\mathrm{NO}_{3}$ through the (usually rapid) process of nitrification. The low ammonium levels recorded in all of the Kowhitirangi bores suggest the nitrate-nitrogen levels measured were representative of nitrogen leaching occurring.

Median chloride concentrations from the three study bores and two NGMP were 2.7 $\mathrm{g} / \mathrm{m}^{3}$ over the study period. While the median chloride levels were low, the Coleman bore, a NGMP bore, showed a significant increasing trend in chloride concentration between 1998-2003. The Anderson bore, located upgradient of all of the other Kowhitirangi study bores showed no trend. Also the Anderson bore is located close to the Hokitika River, so it is possible that there is more dilution of contaminants at this bore compared with the Coleman bore.

Microbial testing of samples from the Kowhitirangi area returned no measurable occurrences of either faecal coliforms or $E$. coli from any of the study bores. Faecal coliforms and $E$. coli are not tested for under the NGMP programme. As a good indicator of effluent contamination, the negative results would suggest the effluent is unlikely to be affecting the study bores, or that any bacteria have died off before reaching the sample point. However, it must be noted that during the laboratory detection limits for the microbial testing changed during the study. During the first and third rounds of sampling a laboratory error saw the detection levels raised to $<5$ $\mathrm{cfu} / 100 \mathrm{ml}$ when it should have been $<1 \mathrm{cfu} / 100 \mathrm{ml}$ as in the second and fourth rounds. Also, no evidence is does not necessarily mean no effluent leaching. 
According to the WCRC Dairy Effluent Database only $12 \%$ of the 50 dairy farms in the Kowhitirangi area were applying their effluent to land during 2001. The majority of effluent disposal techniques at the time of sampling in the Kowhitirangi area were via oxidation ponds and barrier ditches, which then disposed into small streams and drains. With the majority of effluent disposal systems discharging to surface water, the amount of nitrogen added to the land is limited to stock urine, dung patches and fertiliser application which may explain the low levels of nitrate-nitrogen recorded; however, it is also possible that ponds and drains may subsequently leach nutrients to shallow groundwater.

Even with the low concentrations nitrate, chloride and the absence of bacteria in the samples, the trends of both increasing nitrate-nitrogen and chloride concentrations in the Coleman bore suggest that a source of effluent is having an effect on groundwater quality in the vicinity of the bore. Since the closest septic tank is located downgradient of the bore, the dairy farms located upgradient of the bore are likely to be the main source of the increasing chloride and nitrate. While the measured concentrations of both nitrate-nitrogen and chloride over the Kowhitirangi area were low, the increasing trends evident in the Coleman bore are likely to be occurring in other bores nearby. While this cannot be accurately determined due to the short sampling period, similar landuse, climate, and effluent disposal practices that occur over the Kowhitirangi area, suggests that the same trends are occurring elsewhere.

The low concentrations of nutrients and major ions in the groundwater of the Kowhitirangi area, over which landuse is as intensive as the other study areas, may also be partially explained through dilution. The low lying alluvial flats of the Kowhitirangi area are bordered by the Hokitika and Kokatahi rivers. Groundwater levels in the area are high, and transmissivities in the porous alluvial gravels are high (Chapter Three: Hydrogeology). River water typically has nitrate-nitrogen levels less than $1 \mathrm{~g} / \mathrm{m}^{3}$ (Hanson, 2002). Thus the constant recharge from these rivers may be helping to keep levels of contaminants low by dilution. In addition to the influence of river recharge on dilution, the average annual rainfall is significantly higher in the Kowhitirangi area than in the Grey and Inangahua Valleys. 


\subsubsection{Inangahua Valley}

Of the thirty dairy farms in the Inangahua valley, only four were applying their dairy shed effluent to land (WCRC, 1998). These four properties were spread over the valley and were not all located over the same aquifer. The Parkinson farm bore was chosen because of its long history of dairy shed effluent application to land. Milking 440 cows, the Parkinson farm applies effluent to a 40ha area upgradient of the bore. One $200 \mathrm{~m}$ run of the traveling irrigator will irrigate three milkings of effluent. One paddock is irrigated at a time, and the irrigator would stay in the same paddock for 58 days (Mills pers. comm., 2001). The Mitchell brothers farm at Cronadun was chosen as it was the only other accessible bore in the Inangahua valley. The technique of disposal on this property was via a $50 \mathrm{~mm}$ alkathene pipe which ponded the effluent directly to pasture. At the time of the study, the farm was only milking 80 cows.

The mean nitrate-nitrogen concentration at the Mitchell brothers bore was $1.2 \mathrm{~g} / \mathrm{m}^{3}$ and at the Parkinson farm bore it was $3.7 \mathrm{~g} / \mathrm{m}^{3}$. During the August sampling round nitrate concentrations peaked at $6.8 \mathrm{~g} / \mathrm{m}^{3}$ at the Parkinson bore and $1.7 \mathrm{~g} / \mathrm{m}^{3}$ at the Mitchell brothers bore. Chloride concentrations also peaked in August at $7.1 \mathrm{~g} / \mathrm{m}^{3}$ at the Parkinson bore and $8.2 \mathrm{~g} / \mathrm{m}^{3}$ at the Mitchell brothers bore. These patterns of peak chloride and nitrate concentrations occurring at the same time in August, after heavy rain, and when groundwater levels were highest suggest contamination of the groundwater through an effluent source.

\subsubsection{Regional discussion}

Analysis of water types, or hydrochemical facies, by Daughney and Reeves (2003) using the data from the NGMP bores characterised the groundwaters of the West Coast region as oxidised and dilute. This is reflected in the low levels of ammonium measured throughout the region indicating that oxidation of ammonium to nitratenitrogen may have been occurring. The elevated levels of nitrate-nitrogen as discussed above also back this up. Daughney and Reeves (2003) suggest that the overall the dominance of calcium and bicarbonate and the low total dissolved solids of the West Coast groundwaters are the same as would be expected from surface 
waters; suggesting that groundwater recharge is rapid and/or that rock-water interaction is limited therefore implying low residence times. Daughney and Reeves also found that the homogeneity of the groundwater results at the NGMP sites was due to rapid recharge of the shallow aquifers and uniformity of aquifer mineralogy. Their findings, in particular the similarity of the groundwater chemistry to surface water chemistry, support the discussion of the rapid recharge and dominance of river recharge on the Kowhitirangi shallow aquifer.

While the trends of increasing nitrate-nitrogen and chloride over much of the region tend to suggest an effluent-sourced form of contamination is reaching the groundwater, nitrogen sourced from fertiliser cannot be rejected. Nitrogen-based fertilisers such as urea are used heavily on the West Coast. Typical applications are in the order of 100-130 kgN/ha/yr (Mills pers comm., 2001; Parkinson pers comm., 2001; MAF, 2003). Nitrogen isotope analysis (Chapter 5: Age dating and isotope analysis) aids the identification of the source of the nitrogen reaching the groundwater.

Seasonal fluctuations in most of the water quality analytes are evident at many, but not all, of the study sites. Seasonal trends are clearest in the shallow unconfined aquifers of the Kowhitirangi and Totara Flat areas where peaks of nitrate and chloride concentrations were recorded in the spring months and low concentrations were recorded during autumn. In the Ahaura valley the deeper sites show very little seasonal variation whereas the Mills bore, a shallow bore, shows clear seasonality. Seasonal fluctuations occur because during winter, when the rainfall is greatest and the evaporation rates and plant activity are lower, water tables are highest, there is excess soil moisture, and more nutrients, due to lower plant microbial activity, available to percolate through the unsaturated zone and carry nutrients to the groundwater zone (Hanson, 2002). Nitrate concentrations are often seen to decline over the summer or dry months, when there is little available soil moisture, then autumn follows where they are potentially at their lowest (Hanson, 2002) as seen in the data from this study and the NGMP bores (Figure 4.3, Figure 4.5, Figure 4.7, Figure 4.8, Figure 4.13). However, seasonality is also a function of the depth of the bore as it may take longer for moisture to reach deeper groundwater hence delaying 
the peak in concentrations. This may explain the lack of seasonal patterns in the deeper bores of the Ahaura Valley.

One limiting factor in the analysis of the groundwater quality results from this study is the absence of historical background data and the absence of any control bores in the study. While one of the NGMP bores, Anderson, acts partially as a control, more control bores would have allowed comparison of the results collected in this study with uncontaminated natural background levels. It was not within the scope of this study to install dedicated control bores so the available bores had to suffice. However, by using the NGMP bores, long-term trends have been used to demonstrate that increasing trends in the concentrations of nitrate-nitrogen and chloride are evident.

\subsubsection{Potential so urces of error}

Identifying the potential sources of error is an important consideration prior to concluding on the results. Potential sources of error in the groundwater quality research include both sampling and analysis errors.

Potential errors related to the analysis of the samples are likely to be low. Given the analysis of the samples was undertaken at Cawthron Institute, an accredited laboratory, results are assumed to be accurate. However, a lab error did result in higher detection limits for $E$. coli and faecal coliforms during two rounds of sampling.

The physical construction of the bore can lead to potential sources of error. Poor well-head sealing and construction can lead to situations where preferential flow paths may cause surface water to enter the bore/well.

Potential sources of error related to the collection of samples are more numerous. Poor sampling practices have been identified as one of the main the main sources of error in the NGMP (Daughney, pers. comm., 2004). Insufficient purging, or over pumping a well can lead to elevated levels of some analytes, especially iron, in its oxidised form, being recorded. This is due to solids, from the bottom of the bore, or inside of the bore casing, being drawn to the surface. For example, the highest value 
at the Johnson bore may be result of this. The variation in EC results may be an indication of insufficient purging in some cases.

Overall, the consistency between sampling rounds, and between sites of the same area suggest errors in this study were very low. The study is not too concerned with individual values, but more in the trends each site display, and so a broad-bushed approach to any errors can be taken. The sample data also compares well to the NGMP data, giving confidence in the accuracy of the data collected during this study.

\subsection{CONCLUSIONS}

Elevated levels of nitrate-nitrogen and chloride in the samples from the study bores in each of the Kowhitirangi, Grey Valley and Inangahua Valley/Reefton study areas, and increasing trends of nitrate-nitrogen and chloride in NGMP bores in the Kowhitirangi and Grey valley, suggest leaching of nutrients and major ions to groundwater is widespread on the West Coast. Due to the intensive nature of the dairy farming in these areas, and the distance between septic tanks and the bore locations, it is likely that the source of this effluent is from dairy effluent, both effluent from the dairy shed and urine and dung patches left on pasture by stock.

While levels of all major nutrients and ions are currently below both drinking water standards and stock water guidelines, increasing trends of nitrate-nitrogen and chloride in the range of $0.3-0.5 \mathrm{~g} / \mathrm{m}^{3} / \mathrm{yr}$ warrant further monitoring. Particularly as in many areas there is a delay in the effects of landuse being observed in groundwater quality samples (van der Raaij, 2000; Hanson, 2002).

Bores monitored for this study were only sampled four times during 2001; however, it is probable that elevated levels of nitrate-nitrogen and chloride in the study bores surrounding the NGMP bores are an indication of increasing concentrations of nutrients and major ions in these bores. Thus it is likely that leaching to groundwater of nitrogen is more widespread than just around the NGMP bores.

High nitrogen fertiliser application rates $(>100 \mathrm{kgN} / \mathrm{ha} / \mathrm{yr})$ suggest that nitrogen leaching may not be solely due to effluent application to land. A number of farms still 
apply their annual fertiliser input in a single application increasing the chance of the nitrogen leaching to groundwater. Fertiliser nitrogen has been shown (Di et al., 1998) to leach more easily than DSE, highlighting the importance of proper fertiliser management.

Low concentrations of nutrients and major ions in the groundwater of the Kowhitirangi area may reflect the probable dominance of river recharge, on the shallow aquifer even under intensive dairying (future $\mathrm{O}^{18}$ sampling could positively identify recharge sources). In the shallow bores of the Ahaura valley, higher concentrations of nutrients and ions reflect the dominance of rainfall recharge on the groundwater system. The deeper bores in the Ahaura valley have lower levels of some nutrients and ions probably reflecting the depth of the unsaturated zone through which the water has to travel.

The low levels of ammonium-nitrogen suggest that septic tank contamination or rapid leaching of DSE is not occurring in the study areas. DRP levels are generally low, which may be a result of the West Coast soil's high capacity to absorb phosphorus (Mew, 1980).

The number of positive E. coli results is also of concern. Although spatially isolated, the positive results indicate that disposal practices of effluent are a problem. As the $\mathrm{MoH}$ drinking water guideline is $<1 \mathrm{cfu} / 100 \mathrm{ml}$, all positive results are of a health concern.

Acidic $\mathrm{pH}$ levels, outside of the $\mathrm{MoH}$ drinking water guidelines, were measured at all of the sampling bores, on all sampling occasions. The low $\mathrm{pH}$ values are to be a result of the high rainfall and geological influence. The low $\mathrm{pH}$ makes the water 'aggressive' and can lead to corrosion of pipes and plumbing fittings.

Dissolved oxygen levels recorded over the study bores indicate the dominance of oxidised groundwaters in the West Coast region. However, the lower levels of dissolved oxygen measured in the Johnson bore indicated the reducing nature of the groundwater in this deep bore. The consistency in temperature results and the low standard deviation indicate good sampling practices. 
At present a lack of accurate background information exists on groundwater quality. Future work on the effects of landuse on groundwater quality on the West Coast should include the monitoring of non-impacted, or control bores so that accurate assessments of landuse impacts can be made. This may involve the installation of dedicated monitoring bores.

Determining the source of any nitrogen contamination and determining the age of the groundwater will aid the management of landuse practices in the region. The next chapter uses nitrogen isotope analysis to help determine the source of the increasing nitrate-nitrogen levels identified above, and uses age dating to help put these landuse impacts into a temporal perspective. 


\section{AGE DATING AND ISOTOPE ANALYSIS}

In addition to the chemical and microbial analysis outlined in chapter 4, determining the source of the contamination and the age of the groundwater, or mean residence time, is important when assessing aquifer conditions. Nitrogen isotope analysis can aid the determination of whether nitrogen in the groundwater is sourced from fertiliser inputs or from faecal inputs. Quantifying the age of the water, in this case determined through chloroflurocarbon (CFC) analysis, can help determine the history of contamination and what possible future trends may be.

\subsection{NITROGEN ISOTOPE ANALYSIS}

There have been many studies using nitrogen isotopes to determine the source of the nitrate contamination (Bohlke et al., 1995; Kellman et al., 2002; Ostrom et al., 2002). Nitrogen has two stable isotopes, ${ }^{14} \mathrm{~N}$ (derived from natural processes) and the less abundant ${ }^{15} \mathrm{~N}$ (derived from anthropogenic processes). Measuring the ratio between the ${ }^{14} \mathrm{~N}$ and ${ }^{15} \mathrm{~N}$ isotopes potentially allows the source of nitrogen observed in any given sample to be determined. This ratio, the isotopic signature of nitrogen, is expressed as $\delta^{15} \mathrm{~N}$. Inorganic fertilisers with nitrogen that has been atmospherically derived have a $\delta^{15} \mathrm{~N}$ similar to that of air, typically $-4 \%$ o to $+4 \%$, while nitrate from animal effluent and human waste has a more positive $\delta^{15} \mathrm{~N}$ value of between $+10 \%$ to $+25 \%$ o (Kendall et al., 1995).

As nitrogen passes through the nitrogen cycle it undergoes a number of reactions in which fractionation (changes in the balance between ${ }^{15} \mathrm{~N}$ and ${ }^{14} \mathrm{~N}$ ) can occur. Following these reactions the nitrogen substrate is almost always enriched with ${ }^{15} \mathrm{~N}$ (van der Raaij, 2000). While assimilation of nitrogen (the reduction of nitrate to nitrite and then to ammonia) results in organic nitrogen depleted in $\delta^{15} \mathrm{~N}$, mineralisation of organic nitrogen (the transformation of organic nitrogen into ammonium) produces a smaller fractionation, less than $1 \%$. Nitrification (the conversion of ammonium to nitrate through oxidation) produces a much larger fractionation up to $10 \%$. The extent of fractionation is determined by the amount of available nitrogen in the soil. Soils 
with low levels of nitrogen will produce little variation in $\delta^{15} \mathrm{~N}$ fractionation, while soils with higher nitrogen levels will produce greater fractionations. Soils in the West Coast region typically have low to medium levels of nitrogen present with nitrogen content ranging between 0.05 and $0.41 \%$ (Mew, 1980).

Water quality information, whether it is isotopic, chemical or biological is of greater use in determining the potential effects of different landuses when put into a temporal perspective. By dating the groundwater, data from these analyses can be used to determine current and future trends, as well as help determine a history of the contamination.

\subsection{CFC DATING}

Chlorofluorocarbons (CFCs) are entirely anthropogenic contaminants of the atmospheric and hydrologic systems. They have been used worldwide for industrial purposes such as refrigeration, air-conditioning and pressurising aerosol cans. In addition to these industrial uses, they have been used as tracers in groundwater to determine the estimated recharge dates for aquifers (Stewart and Morgenstern, 2001).

The CFC concentration in the atmosphere has gradually increased from levels of zero in 1940 to the present levels of several hundred pptv, 1 pptv is one part per trillion by volume or $10^{-12}$ (Figure 5.1; Stewart \& Morgenstern, 2001). Since CFCs are soluble in water they can enter groundwater systems during recharge. Once in the groundwater zone they are isolated from unsaturated zone air so that the dissolved concentrations reflect atmospheric concentrations at the time of recharge (Plummer and Bunsenberg, 2000). Hence, by knowing the input function of CFCs and their solubility in water the measured concentration in groundwater can be used to estimate the recharge date (Dunkle et al., 1992; Plummer and Bunsenberg, 2000). 


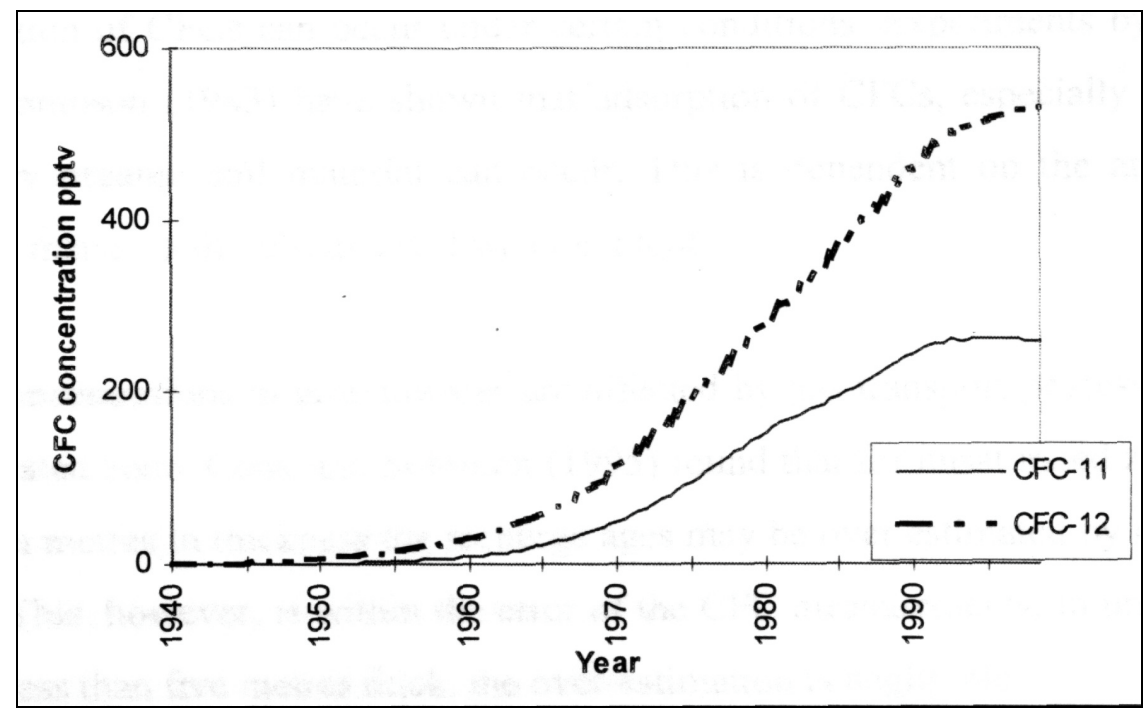

Figure 5.1: CFC concentrations in the atmosphere; source: van der Raaij (2001)

The recharge date is the date at which CFCs were introduced to the water and not to the age of the water itself. The difference between the recharge date and the age of the water is determined by how well the CFCs are transported in the aqueous phase. The calculated age is referred to as the 'model' date, as a number of assumptions are made to simplify the calculation (van der Raaij, 2000).

CFCs are now being phased out of production because of their destructive effects on the ozone layer. During the 1990s this led to a dramatic slowing in the increase in CFC concentrations. This means CFC dating is not as accurate as other methods for groundwater recharged after 1990 (Stewart \& Morgenstern, 2001). Other factors also affect the accuracy of CFC dating. The solubility of CFCs is affected by temperature, for example overestimating the a recharge temperature gives ages that are too old and vice-versa. Local sources of CFCs, especially in urban areas, can cause 'excess' CFCs in groundwater resulting in dates being too young. Anaerobic degradation or sorption onto organic matter results in ages that are too old (Stewart \& Morgenstern, 2001), although the dissolved oxygen concentration of the water can be used to determine the likelihood of this.

Despite these potential problems CFC measurements have given good results in New Zealand conditions (Stewart \& Morgenstern, 2001). CFC dating has been used in several studies of groundwater contamination (for example, Johnson et al., 1998; Trompetter and van der Raaij, 1999; van der Raaij, 2000) 


\subsection{METHODOLOGY}

The field sampling and analysis for CFCs was conducted by Robert van der Raaij from the Institute of Geological and Nuclear Sciences (GNS). Nitrogen isotope sampling was undertaken during the second sampling round in June 2001. Samples were stored on ice and kept below $4^{\circ} \mathrm{C}$ throughout transportation. As a pre-treatment, samples were filtered through a 0.45 micron filter then treated with $10 \mathrm{ml}$ of concentrated hydrogen peroxide in the water quality laboratory at Victoria University. After the pre-treatment samples were analysed at GNS.

\subsection{RESULTS}

\subsubsection{Nitrogen Isotope Results}

Six of the study sites were selected for this part of the study. The six sites were selected based on the six highest nitrate-nitrogen results obtained after the first round of water quality sampling in April 2001 (Table 5-1). The sampling for the Nisotope analysis was conducted at the same time as sampling for the chemical analyses was conducted ensuring that the same collection protocol were adhered to (as discussed in chapter 4).

\begin{tabular}{l|c|c}
\multicolumn{1}{c|}{ Well } & $\begin{array}{c}\mathrm{NO}_{3}-\mathbf{N} \\
(\mathbf{S t d} . \mathbf{D e v}) \\
\left(\mathbf{g} / \mathbf{m}^{3}\right)\end{array}$ & $\delta^{15} \mathbf{N}(\%)$ \\
\hline Parkinson Farm @ Reefton & $3.77(2.05)$ & 4.58 \\
\hline Havill Farm @ Ikamatua & $3.07(0.73)$ & 3.67 \\
\hline Galligans Res @ Ahaura & $2.42(0.38)$ & 4.18 \\
\hline Bray Farm @ Ahaura & $2.25(0.1)$ & 3.58 \\
\hline Mills Farm @ Ahaura & $5.47(2.06)$ & 1.51 \\
\hline Beggs Farm @ Totara Flat & $3.67(1.22)$ & 3.40
\end{tabular}

Table 5-1: Nitrogen Isotope and values. $\mathrm{NO}_{3}-\mathrm{N}$ values are average values calculated over the study period (see Chapter 4 - Water Quality). 
The results form the six sites showed little variation about the mean of $3.48 \%$ o (standard deviation of $1.06 \%$; Table $5-1$ ). The values varied between $1.51 \%$ and $4.58 \%$. The three sites located in the Ahaura Valley (Galligans, Bray and Mills) varied from $1.51 \%$ to $4.18 \%$. Galligan's residence and Brays farm are located close to each other near the head of the farmed part of the valley and returned similar $\delta^{15} \mathrm{~N}$ values. Mills' farm, located further down the valley is shallower and returned a lower $\delta^{15} \mathrm{~N}$ value of $1.51 \%$. Havill farm at Ikamatua, and Beggs farm at Totara flat, both further up the Grey Valley from Ahaura returned values of $3.67 \%$ and $3.40 \%$ respectively. Parkinsons farm at Reefton had the highest $\delta^{15} \mathrm{~N}$ value of $4.58 \%$.

The significance of these results are discussed after consideration of the age of the water since sensible discussion of the $\mathrm{N}$-isotope results requires an understanding of the age of the groundwater.

\subsubsection{Chlorofluorocarbon dating results}

Five sites were chosen by WCRC for CFC dating analysis, with the cost of the sampling spilt between the WCRC and Victoria University. Results from only four of the 5 bores analysed are reported, this is due to the fifth bore being located outside of the study area (Table 5-2). 


\begin{tabular}{|c|c|c|c|c|c|}
\hline \multirow[t]{2}{*}{ Bore } & \multicolumn{2}{|c|}{$\begin{array}{c}\text { Calculated } \\
\text { Atmospheric } \\
\text { Pressure in pptv }\end{array}$} & \multicolumn{2}{|c|}{$\begin{array}{c}\text { Model CFC } \\
\text { Recharge Dates }\end{array}$} & \multirow[t]{2}{*}{$\begin{array}{l}\text { Recommended } \\
\text { Recharge Year }\end{array}$} \\
\hline & CFC-11 & CFC-12 & CFC-11 & CFC-12 & \\
\hline $\begin{array}{l}\text { Anderson, } \\
\text { Kowhitirangi }^{1}\end{array}$ & 189.6 & 508.5 & 1984.0 & 1993.8 & 1993 \\
\hline $\begin{array}{l}\text { Coleman Farm, } \\
\text { Kowhitirangi }^{1}\end{array}$ & 212.6 & 610.7 & 1986.8 & Hi Cont. & \\
\hline $\begin{array}{l}\text { Havill, } \\
\text { Ikamatua }^{2}\end{array}$ & 200.8 & 467.0 & 1985.5 & 1990.0 & 1990 \\
\hline Mills, Ahaura ${ }^{2}$ & 209.8 & 452.8 & 1986.3 & 1989.3 & 1989 \\
\hline
\end{tabular}

Table 5-2: Measured CFC concentrations and derived recommended recharge years

The results from the CFC analysis showed little variation in ages (Table 5-2). Concentrations, expressed above as equlivalent atmospheric partial pressures varied from 189.6pptv to 212.6pptv for CFC-11 and from 452.6pptv to $654.1 \mathrm{pptv}$ for CFC12. These values, expressed as model recharge dates correspond to recharge years of between 1984 and 1986 for CFC-11 and 1989-1993 for CFC-12. Results of the CFC-12 analysis at the Coleman (Kowhitirangi) site returned 'Hi Cont' result. A 'Hi Cont' result means that a higher than expected concentration of CFC's than would be expected from a modern sample was found. This can often be attributed to the selected recharge temperature. CFC-12 dates are older than CFC-11 dates in all cases, ranging from 3 years to 9 years older. This can be attributed to CFC-11 degradation and adsorption and is consistent with other New Zealand groundwaters (van der Raaij, 2000).

Recommended recharge years (RRY) in Table 5-2 are based on the CFC-12 model recharge dates because of the CFC-11 degradation. In the Kowhitirangi area Anderson's farm had an apparent age of 8 years (RRY of 1993) while Coleman farm returned a 'Hi Cont.' result. The Coleman farm bore is located in the same gravels and has the same surrounding land as Anderson's farm so it is suggested (van der 
Raaij pers. comm., 2002) that the ages should be similar. In the Grey Valley the Havil farm bore had an apparent age of 11 years (RRY of 1990) and the Mills farm bore had an apparent age of 12 years (RRY of 1989).

\subsection{DISCUSSION}

The six bores with elevated nitrate levels that were sampled for nitrogen isotopes had an average $\delta^{15} \mathrm{~N}$ of $3.5 \%$. This is consistent with either a fertiliser or a soil organic nitrogen source of nitrate. Based solely on the nitrogen isotope results, the nitrates detected over the study areas would appear not to be sourced from animal effluent, for which a $\delta^{15} \mathrm{~N}$ greater than $10 \%$ o would be expected (van der Raaij, 2000). However, the strong trend of increasing nitrate levels diplayed in the NGMP data from the Bertacco bore would suggest that a source other than natural soil organic nitrogen is contaminating the groundwater at this site, i.e. nitrate contamination is likely to be from fertiliser use.

Recharge dates calculated from CFC concentrations indicate that the groundwater from both study areas sampled is young. This can be attributed to the shallow unconfined nature of the bores, especially in the Kowhitirangi area. Bores in the Kowhitirangi area are typically $7 m-10 m$ deep, often with no screen or screened between $7 \mathrm{~m}$ and $10 \mathrm{~m}$. The Anderson bore, a NGMP site from September $1998-$ September 2001 is a $10 \mathrm{~m}$ deep bore, screened between $8 \mathrm{~m}$ and $10 \mathrm{~m}$. Water from this bore was dated to 1993 (sampling was undertaken in 2001), suggesting the water is approximately 8 years old. The Coleman farm bore, also $10 \mathrm{~m}$ deep, and screened from $8 m-10 m$, gave an inconclusive result. However, with a similar strata record to the Anderson bore the age of the water would be of a similar age to that of the Anderson bore.

The young age of the water in the shallow Kowhitirangi aquifer suggests both high transmissivity and rapid recharge rates. As it is young and shallow water, the effects of landuse above the aquifer will show up more quickly in terms of degraded groundwater quality, than if it were a deeper or more confined systems. Levels of contaminants that may be detected in the shallow Kowhitirangi aquifer, are likely to be a result of landuse practices only 7-8 years ago. 
Ten years ago, the landuse surrounding these farms was still dairying; however, in the past decade there has been an increase in stocking density, herd size, total number of cows milked as well as an increase in fertiliser use over the region. Stocking rates for example have increased from an average of well below 2.0 cows per hectare in 1990 to 2.3 cows per hectare in 2003 (LIC, 2003). Fertiliser use, in the form of nitrogen, has increased from rates of between $50-80 \mathrm{kgN} / \mathrm{ha}$ in 1990 to rates of between 100-130 kgN/ha in 2003 (MAF, 2003).

However, even with the intensification of landuse practices, groundwater in the Kowhitirangi area is still of a high quality. The average nitrate-nitrogen level recorded over the period September 1998-June 2002 for both the NGMP bores and the bores selected for this study was $0.86 \mathrm{~g} / \mathrm{m}^{3}$. The average chloride level for the area was $3.07 \mathrm{~g} / \mathrm{m}^{3}$ for the same period. Both nitrate-nitrogen and chloride provide a good indication of effluent contamination and the levels reported here suggest that there is little to no contamination of this shallow aquifer. Dissolved Reactive Phosphorus (DRP) is often used as an indicator of fertiliser contamination (Rosen, 2001; Watts, 2002). The average level of DRP in the Kowhitirangi area, measured from the study bores and the NGMP bores was $0.01 \mathrm{~g} / \mathrm{m}^{3}$. This low level may suggest use of phosphorus-based fertilisers, such as Superphosphate, is not having a detrimental effect on groundwater quality in this area, however Phosphorus can often bind to the soil and not move into groundwater for a considerable time.

The ages of water reported from the Grey Valley were slightly older than those at Kowhitirangi. Water from the Mills farm bore was aged at 12 years and water from the Havill farm, on the upper terraces of the Grey valley at Ikamatua was aged at 11 years. This water is still regarded as young in term of groundwater ages.

Dairy farms in the Grey Valley have undergone the most intensification of any of the West Coast dairying areas. As a result both land application of dairy shed effluent and fertiliser use has increased substantially in the past decade (Mills pers. comm., 2001; MAF 2003). Figure 5.2 shows the increasing trend of nitrate-nitrogen recorded from the Bertacco bore in the Ahaura Valley and also shows the elevated levels of nitrate-nitrogen recorded in the Mills bore. Isotope analysis, as discussed above, 
suggests that these elevated levels of nitrate-nitrogen in the Ahaura Valley are possibly from a fertiliser nitrogen source, and not from an effluent source. However, research by Di et al (1998) suggests that fertiliser nitrogen is more mobile than DSE nitrogen, and therefore the possibility of DSE nitrogen leaching to the groundwater in these areas cannot be discounted. It is possible in the case of the Mills farm bore, that fertiliser nitrogen has leached through to the groundwater, and that DSE nitrogen has yet to leach through.

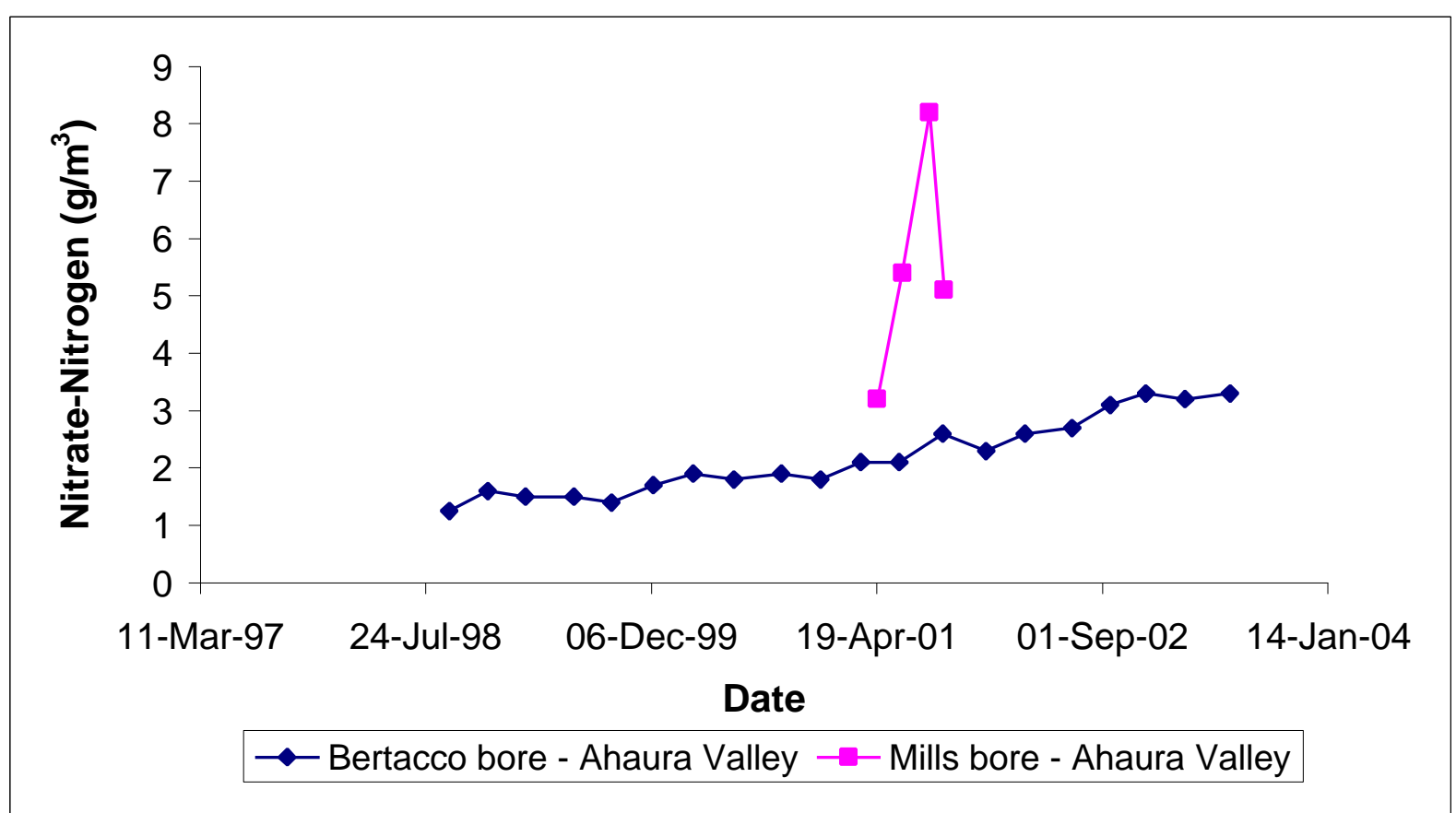

Figure 5.2: Nitrate-nitrogen values in the Bertacco and Mills bores, Ahaura Valley

The average nitrate-nitrogen concentration over all of the study bores in the Ahaura valley, including the Bertacco NGMP bore was $2.34 \mathrm{~g} / \mathrm{m}^{3}$. The average chloride concentration for the same bores was $7.3 \mathrm{~g} / \mathrm{m}^{3}$. The average dissolved reactive phosphorus concentration was $0.02 \mathrm{~g} / \mathrm{m}^{3}$. While these average results are all well below guideline values, trends seen in the Bertacco bore would suggest that landuse practices in the Ahaura valley are affecting groundwater quality in the surrounding area (Figure 5.3). 


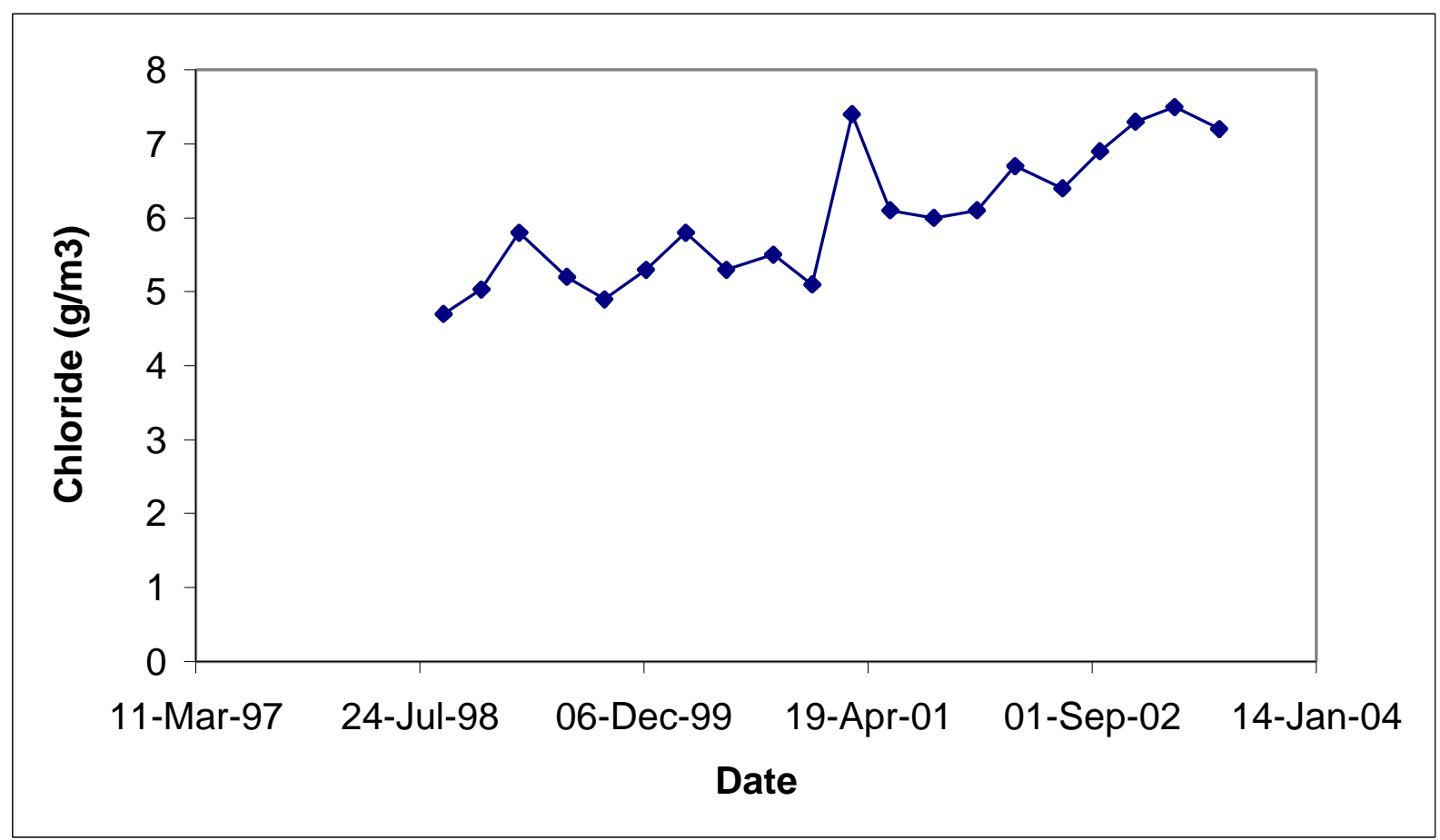

Figure 5.3: Chloride levels in the Bertacco bore, Ahaura Valley.

Trend analysis of chloride levels in the Bertacco bore (Figure 5.3) show a significant increasing trend in chloride concentrations over time. Both the increasing trends in chloride concentrations and the increasing trends in nitrate-nitrogen suggest that human or animal sewage source(s) are affecting groundwater quality in the surrounding area. Unfortunately nitrogen isotope analysis was not conducted on this bore so the source of the nitrate contamination cannot be conclusively determined.

\subsection{CONCLUSIONS}

Nitrogen Isotope analysis of groundwater from the Kowhitirangi and Grey Valley areas has shown that with an average $\delta^{15} \mathrm{~N}$ of $3.5 \%$. Nitrogen in the groundwater of these areas is likely to be from a fertiliser or soil organic nitrogen source rather than from a human or animal sewage source. However, the strong increasing trends in nitrate-nitrogen and chloride detected in the Bertacco NGMP bore suggest that there is likely to be a source of effluent affecting groundwater quality near this bore. Considering the age of the ground water in the Ahaura valley, it is likely that fertiliser nitrogen has leached through to the groundwater, and DSE nitrogen, which has only been applied over the past $10-15$ years, has yet to leach though to the groundwater. 
Age dating of West Coast groundwaters through chloroflurocarbon analysis has shown that water in the Kowhitirangi district and the Grey Valley is predominantly young water aged between 8 and 12 years old. This age suggests that contaminants measured in the shallow groundwater zones are a result of relatively recent landuse effects. It also suggests that mean residence times of groundwater in the shallow alluvial aquifers of the West Coast are short. This short residence time has implications in situations where groundwaters are discharged to surface waters.

However, even with short residence times and young groundwater, the effects of the past decade of intensification are yet to be seen in the groundwater quality data. The increasing trends of nitrate-nitrogen and chloride suggest that further future increases are likely to occur.

Further study of nitrogen sources and water ages is required in the West Coast region, especially in the intensively farmed areas of the Grey Valley and Kowhitirangi areas. The increasing trends of nitrate-nitrogen and chloride seen in the NGMP bores and the elevated levels seen in the study bores warrant further investigation. Further study of nitrogen isotopes, especially in areas yet to be studied, will help to accurately determine the source(s) of the observed nitrogen. Then measures can be taken to help mitigate potential future changes.

An important part of planning and investigating the effects of landuse on groundwater quality is to model different scenarios. Modeling both nutrient balances and the effects of fertiliser and dairy shed effluent application on groundwaters can be used to determine sustainable application rates and can be used to provide a benchmark against which to compare the current and observed values. 


\section{NITROGEN LEACHING AND APPLICATION RATES}

Nitrogen leaching to groundwater from grazed dairy pasture systems is a major environmental concern in many countries. With increased fertiliser use and intensification of dairy systems in New Zealand over the past decade, the potential for contamination of groundwater bodies through nitrate-nitrogen leaching increased (Silva, 1999; Di and Cameron, 2000). Elevated levels of nitrate-nitrogen in drinking water are associated with human health concerns. Thus the New Zealand Ministry of Health has set a standard which limits the nitrate-nitrogen $\left(\mathrm{NO}_{3}-\mathrm{N}\right)$ concentration in drinking water to $11.3 \mathrm{~g} / \mathrm{m}^{3}$ which is the same standard as set by the World Health Organisation (MoH, 2000).

Evidence of elevated, and increasing, concentrations of nitrate-nitrogen has been shown for groundwater on the West Coast (Chapter 4: Groundwater Quality). While current nitrate-nitrogen concentrations in all of the study bores are below the national drinking water guidelines, the trends of increasing concentrations evident in some of the study bores warrant further investigation. No studies have been carried out on the West Coast to investigate nitrogen budgets and potential nitrate leaching to the groundwater. While there is no management of nitrogen inputs to groundwater anywhere in New Zealand, nitrogen applied to the ground is managed. The West Coast Regional Council (WCRC) manages the application of nitrogen to the ground through the Regional Plan for Discharges to Land. This plan currently specifies a nitrogen loading rate of $275 \mathrm{kgN} / \mathrm{ha} / \mathrm{yr}$. This application rate is high compared to rates set by other New Zealand regional councils (e.g. Environment Waikato specifies a maximum rate of $150 \mathrm{kgN} / \mathrm{ha} / \mathrm{yr}$ ).

Nitrogen leaching is a result of a suite of complex processes within the broader framework of the nitrogen cycle. Nitrate leaching processes, rates and amounts are affected by a number of soil, environmental and management conditions ( $\mathrm{Di}$ and Cameron, 2000). While no studies have been conducted on the West Coast, across New Zealand a large number of investigations of the rates of nitrate leaching following the application of nitrogen fertilisers and/or animal wastes are available to aid groundwater management (Ryden et al., 1984; Ledgard et al., 1996; Di et al., 
1998; Barkle et al., 2000; Di and Cameron, 2002). To help manage nitrogen leaching losses in New Zealand agricultural systems a number of models have been developed. The application of two models are used in this study to determine nitrate leaching losses under modeled nitrogen application rates. The Nitrogen Leaching Estimation model (NLE; Di and Cameron, 2002) is a semi empirical model for estimating nitrogen losses and critical nitrogen application rates. The OVERSEER model (Ledgard et al., 1999) is an empirical model for calculating nutrient budgets and estimating nitrogen leaching. Both of these models require site specific and regionally specific data, which is scarce for the West Coast region.

The effects of elevated nitrate concentration and the processes within the nitrogen cycle are first explained to provide a background to the issue of nitrate leaching. Then, considering the results from the models and the current levels of nitrate contamination of the study sites, the current management techniques are evaluated and a revised nitrogen loading rate suggested.

\subsection{EFFECTS OF ELEVATED NITRATE LEVELS IN GROUNDWATER}

For some time it has been recognised that high concentrations of nitrogen, specifically nitrate, in drinking water can cause health problems. The main health problem associated with high nitrate levels is methemoglobinemia (Comly, 1945; Burden, 1982; Davies, 2001). Methemoglobinemia is a blood disorder that mainly affects children under six months of age in which the ability of red blood cells to carry oxygen is reduced. Methemoglobin is a form of hemoglobin in which the reduced iron in hemoglobin is transformed to its ferric state and is unable to deliver oxygen (Close et al., 2001). The victim often has a blue discolouration of the skin because of the reduced oxygen supply in the blood, hence the common term of methemoglobinemia is Blue Baby Syndrome.

Comly (1945) first discovered that infants are more susceptible than adults to methemoglobinemia. The main reason for this is due to the fact that infants have a lower stomach acidity that allows the growth of bacteria capable of converting nitrate to nitrite. Nitrite has the ability to change haemoglobin to methemoglobin, which cannot carry oxygen. 
Since 1945 there have been 2000 reported cases of infant methemoglobinemia with approximately $8 \%$ of these cases leading to death (Bramwell, 2000). Nitrate contamination is treated seriously; the World Health Organisation is constantly reevaluating its maximum allowable level, which is currently at $11.3 \mathrm{~g} / \mathrm{m}^{3}$ as $\mathrm{NO}_{3}-\mathrm{N}$ (50 $\mathrm{g} / \mathrm{m}^{3}$ as nitrate). New Zealand adopted this level under the $\mathrm{MoH}$ Drinking Water Standards (2000) as set by the Ministry of Health. Although most cases of infant methemoglobinemia have been reported for drinking water with nitrate-nitrogen concentrations greater than $20 \mathrm{~g} / \mathrm{m}^{3}$, a margin of error was considered necessary (Close et al., 2001).

Overseas research has also linked elevated nitrate levels in drinking water with hypertension, central nervous system birth defects, certain cancers, Hodgkin's lymphoma and diabetes (Close et al., 2001); however, in all of these cases definitive links are lacking and more research is needed to confirm the relationships. Elevaled concentrations of nitrates are also toxic to stock at high levels (Barber and Wilson, 1972) and accordingly a guideline of $30 \mathrm{~g} / \mathrm{m}^{3}$ has been set for nitrate in stock water under the ANZECC (2000) stock water guidelines.

In addition to the health implications, elevated nitrogen levels are also recognised to lead to nutrient enrichment of lakes, rivers and sea water (Barber and Wilson, 1972). This is known as eutrophication. Recent work in New Zealand has been investigating the effects of elevated nitrate-nitrogen levels in recharge water entering Lake Taupo (Vant, 2003) and Lake Rotorua (Environment Bay of Plenty, 2004). It is thought that under natural conditions biological growth in these lakes has been limited by the amount of nitrogen available (White, 1983). Additional nitrogen inputs to these lakes has been linked to algal blooms, excess weed growth and changes in the lake's ecology.

The processes leading to elevated nitrate levels and the above effects are complex (Freeze and Cherry, 1979; Di and Cameron, 2000). The next section outlines the nitrogen cycle and explains the processes controlling nitrate leaching in the subsurface environment. 


\subsection{THE NITROGEN CYCLE}

In this section the nitrogen cycle (Figure 6.1) and the main pathways of nitrogen in a clover-based dairy system are discussed. It is important to describe these cycles and pathways as they are key to determining both nitrogen leaching rates and nitrogen application rates in dairy systems.

Nitrogen is the most abundant element in the atmosphere, totalling approximately $79 \%$ of the atmosphere (Close et al., 2001). Nitrogen enters the land surface naturally either through the fixation of nitrogen gas by lightening strikes, or as nitrate dissolved in rain. In the Southern Hemisphere these natural contributions are small when compared to anthropogenic sources (Close et al., 2001). Anthropogenic sources in New Zealand include fertilisers, effluent deposited by grazing animals and effluent disposal of both human and animal wastes.

Although nitrate-nitrogen $\left(\mathrm{NO}_{3}-\mathrm{N}\right)$ is the most abundant form of nitrogen in groundwater, dissolved nitrogen also occurs in the forms of ammonium $\left(\mathrm{NH}_{4}{ }^{+}\right)$, ammonia $\left(\mathrm{NH}_{3}\right)$, nitrite $\left(\mathrm{NO}_{2}{ }^{-}\right)$, nitrogen $\left(\mathrm{N}_{2}\right)$, nitrous oxide $\left(\mathrm{N}_{2} \mathrm{O}\right)$ and organic nitrogen; organic nitrogen is nitrogen that is incorporated into organic substances (Freeze and Cherry, 1979).

Anthropogenic sources of nitrate-nitrogen such as buried organic wastes, human and animal effluent and fertiliser are described as direct nitrate sources zones (Freeze and Cherry, 1979). Nitrate can also originate from the conversion of organic nitrogen, which can occur naturally or be introduced from anthropogenic sources. The process of conversion from organic nitrogen to $\mathrm{NH}_{4}{ }^{+}$is known as ammonification or mineralisation (Freeze and Cherry, 1979; van der Raaij, 2000). Through nitrification, $\mathrm{NH}_{4}{ }^{+}$is converted to $\mathrm{NO}_{2}{ }^{-}$and then to $\mathrm{NO}_{3}{ }^{-}$by oxidation. Ammonification and nitrification are processes that normally only occur above the water table in the soil zone where organic matter and oxygen are more abundant (Freeze and Cherry, 1979; Figure 6.1). The ammonium formed through mineralisation may be lost to the atmosphere as gaseous ammonia through volatilization (van der Raaij, 2000). Some of this ammonia gas may be retuned to the soil through rainfall. 


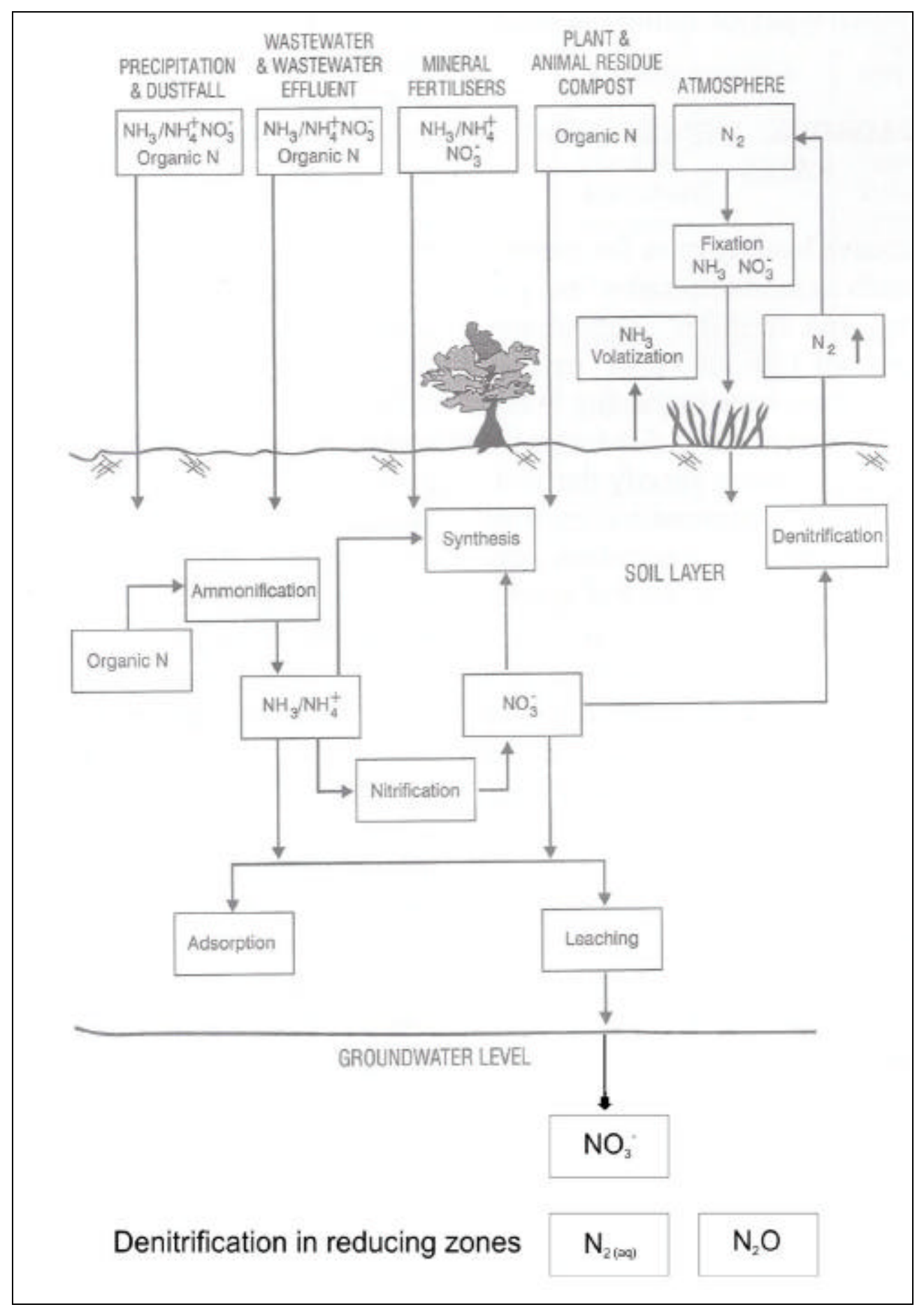

Figure 6.1: Sources and pathways of nitrogen in the subsurface environment; source: modified from Close et al., 2001.

Nitrogen from un-treated wastewater may be either ammonium or organic nitrogen, and nitrogen from chemical fertilisers is generally either $\mathrm{NH}_{4}{ }^{+}$or $\mathrm{NO}_{3}{ }^{-}$. Nitrogen from animals is in the form of urea $\left(\mathrm{H}_{2} \mathrm{NCONH}_{2}\right)$ from urine, or organic $\mathrm{N}$ in faecal material. This is then converted to ammonium through hydrolysis reactions (urea) or decomposition (faecal material) (Close et al., 2001) and then converted by 
ammonification as described above. Organic nitrogen may enter directly into aquifers if the water table is near the surface or if poor well head protection allows (Close et al., 2001). Nitrite only occurs in significant concentrations near contaminated sites (i.e sewage or organic waste disposal areas; Jarvis, 1993)

In aquifers with abundant oxygen (usually unconfined aquifers), $\mathrm{NO}_{3}-\mathrm{N}$ is the stable form of nitrogen in the water. Where oxygen is depleted in the aquifer (usually in confined aquifers), $\mathrm{NH}_{4}-\mathrm{N}$ is the stable form. Organic-N can occur in both types of aquifers; however, it is not normally found in abundant quantities in uncontaminated New Zealand aquifers (Close et al., 2001)

In the process of denitrification $\mathrm{NO}_{3}{ }^{-}$is reduced to $\mathrm{N}_{2} \mathrm{O}$ or $\mathrm{N}_{2}$ returning fixed nitrogen in the soil to the atmosphere. Denitrification only occurs in oxygen deficient conditions and when organic material is present (Freeze and Cherry, 1979). Typical oxygen deficient conditions only occur in confined aquifers, but may also occur in shallow unconfined aquifers associated with wetlands or contaminated with organic waste (Close et al., 2001)

The nitrate ion is the only form of nitrogen sufficiently mobile enough to allow any substantial leaching from the soil system to groundwater (Vinten and Smith, 1993). Because the concentrations of nitrate are not limited by solubility constraints, and because of its anionic form, it is highly mobile in water. There is no practical limit to the concentration of nitrate in groundwater (van der Raaij, 2000), hence its management is deemed very important by regional authorities. Attenuation of nitrate is limited to denitrification or dilution by water with lower nitrate levels (Clark and Frtiz, 1997) and reduction of nitrate to ammonia (van der Raaij, 2000). Thus managing the input of nitrogen to the soil body is important.

\subsection{NITROGEN MANAGEMENT TOOLS}

Regional councils generally control the management of nitrogen leaching through setting of nitrogen and hydraulic loading rates. Permitted nitrogen loading rates in New Zealand currently range from $150-300 \mathrm{kgN} / \mathrm{ha} / \mathrm{yr}$. In some regions these rates include fertiliser nitrogen inputs and in other regions fertiliser nitrogen inputs are 
considered separately from dairy shed effluent inputs. The amount of control and discretion needed to effectively manage the environmental risk is difficult to assess and depends on many factors including local attitudes toward discharge, physical factors such as soil type and rainfall, and the costs involved (MFE, 1999).

By specifying a nitrogen loading rate, the minimum and maximum effluent irrigation areas for a particular herd size can be calculated, allowing the farmer a relatively easy management calculation. The calculation is based on assumptions including the amount of nitrogen produced per cow, the volume of effluent produced and the lactation period - all of which can vary greatly between farms and between regions (MFE, 1999). Approximately one third of New Zealand councils do not specify a nitrogen loading rate under a regional plan, but treat land application as a controlled activity and instead choose to specify hydraulic application depths and application areas on a per consent basis. The rates set under regional plans for the remaining two thirds of councils vary considerably.

The West Coast Regional Council has a nitrogen loading rate of $275 \mathrm{~kg} / \mathrm{N} / \mathrm{yr}$ set under its Regional Plan for Discharge to Land (2002). This loading rate is currently the second highest in New Zealand (Table 6-1) after Environment Bay of Plenty's (EBOP) which is set at $300 \mathrm{kgN} / \mathrm{ha} / \mathrm{yr}$; however, EBOP's loading rate is currently under review and is likely to be reduced substantially in mid 2004. Initial advice from WCRC staff to the council was to set the nitrogen loading rate at $200 \mathrm{kgN} / \mathrm{ha} / \mathrm{yr}$ but this was increased in the final plan following submissions from the farming community concerned that it was unnecessarily low. 


\begin{tabular}{|c|c|}
\hline Council & Nitrogen Loading Controls \\
\hline NRC (permitted) & No specific controls \\
\hline ARC (permitted) & 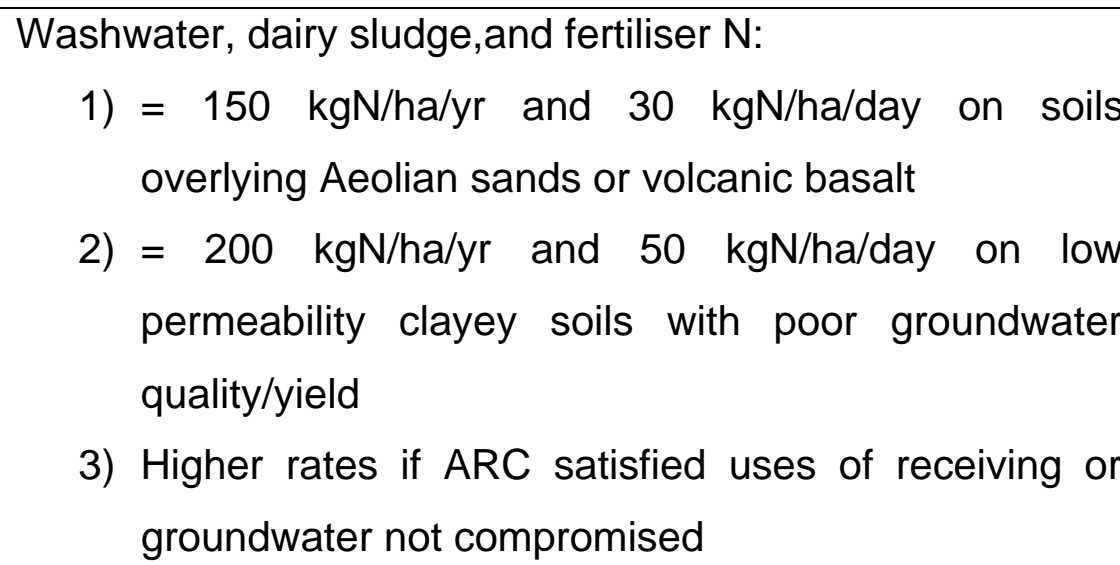 \\
\hline EW (permitted) & $\begin{array}{l}\text { Effluent } \mathrm{N} \text { loading rate }=150 \mathrm{kgN} / \mathrm{ha} / \mathrm{yr} \text { including discharges } \\
\text { from standoff and feed pads }\end{array}$ \\
\hline EBOP (controlled) & Effluent $\mathrm{N}=300 \mathrm{kgN} / \mathrm{ha} / \mathrm{yr}$ (under review) \\
\hline TRC (controlled) & Effluent $\mathrm{N}=200 \mathrm{kgN} / \mathrm{ha} / \mathrm{yr}+$ no limits on fertiliser $\mathrm{N}$ \\
\hline WCRC (permitted) & Effluent $\mathrm{N}=275 \mathrm{kgN} / \mathrm{ha} / \mathrm{yr}+$ no limits on fertiliser $\mathrm{N}$ \\
\hline
\end{tabular}

Table 6-1: National Nitrogen Loading Rates; source: after MFE (1999)

Nitrogen loading rates set by councils vary considerably and establishing a accurate loading rate is difficult. Regional councils must take into consideration physical and scientific factors, the needs and expectations of the farmers, and the needs and expectations of the regions population on general (MFE, 1999). While this may sound simple, factors such as the cost of machinery and the cost of the time involved to irrigate a large area must be considered during the setting of policy. Nonetheless, adopting a high loading rate may pose a risk to groundwater quality.

Regional councils can also choose whether or not the land application of DSE and nitrogen fertilisers is managed as a controlled or a permitted activity. A controlled activity requires a resource consent and individual conditions applicable to the individual characteristics of the application can be set. Under a permitted activity rule, a consent is not required subject to conditions of the rule being met. By making the discharge of DSE to land a permitted activity, the WCRC believes they are 'providing an incentive to dispose of effluent onto land rather than into water, which has higher potential for adverse effects' (WCRC, 2002); this is similar logic to that applied by 
many regional councils. The conditions, which must be met under the WCRC's Land Application of Agricultural Effluent Rule, are:

- there is no runoff of agricultural effluent into water bodies, drains,groundwater or coastal water;

- there is no ponding, flooding and pasture burning;

- notwithstanding condition (a), no dairy farm, piggery, or poultry farm effluent is discharged within:

(i) 100 metres of any well or bore used for potable water supply or stock water supply;

(ii) $20 m$ of any water body;

(iii) $20 m$ of any drain;

(iv) 20m of any adjoining property;

- the application rate from any combination of sludge accumulated from treatment facilities, storage facilities, agricultural effluent, wastewater and whey is at a rate not exceeding the equivalent of $275 \mathrm{kgN} / \mathrm{ha} / \mathrm{yr}$;

- sludge accumulated from storage facilities is not applied to land at a depth greater than 20 millimetres $\left(200 \mathrm{~m}^{3} / \mathrm{ha} / \mathrm{yr}\right)$;

- there are contingency measures in place to ensure that there is no contravention of these conditions in the event of pump or other system failure, or unsuitable soil conditions;

- a financial contribution is paid to the West Coast Regional Council before 30 June each year (WCRC, 2002)

The application of fertiliser to land is also a permitted activity within the West Coast Region. Under the Discharges to Land Plan, any application rate of fertiliser is allowed as long as it meets the following conditions:

- there is no contamination of water; and

- any drift derived from the discharge is not noxious, dangerous, offensive or objectionable beyond the target area to such an extent that it has or is likely to have an adverse effect on the environment;

- any discharge of whey as a fertiliser meets the following additional conditions: 
(i) there is no runoff into water bodies, drains, groundwater or coastal water;

(ii) there is no ponding or pasture burning;

(iii) the application rate of any combination of whey, agricultural effluent, sludge, and wastewater does not exceed the equivalent of $275 \mathrm{kgN} / \mathrm{ha} /$ year.

(WCRC, 2002)

In effect, any application of nitrogen fertiliser is allowed under this rule. It has been well documented in New Zealand that the over-application of nitrogen-based fertilisers can cause leaching of nitrates into groundwater (Di et al., 1998; Ledgard et al., 2000; Silva et al., 1999; Roberts, 1997). While the first condition of this rule states that there should be 'no contamination of water' it is hard to prove that no contamination of groundwater is occurring without intensive investigation of every farm applying fertiliser. Results from the nitrogen isotope analysis (Chapter 5: Age dating and Isotope Analysis) suggest that some of the nitrate contamination present in West Coast groundwaters is from nitrogen fertiliser application, indicating that this current rule may not be sufficiently safeguarding the region's groundwater quality.

The WCRC Land Application of Agricultural Effluent Rule has been operative since April 2002. Prior to the implementation of the Discharges to Land Plan (2002), the land application of dairy shed effluent was not a controlled activity. However, according to information supplied by the owners of the farms studied, application rates from those farms historically applying DSE to land were previously below the $275 \mathrm{kgN} / \mathrm{ha} / \mathrm{yr}$ (Bray pers. comm., 2001; Bull pers. comm., 2001; Mills pers. comm., 2001; Parkinson pers. comm., 2001).

With trends of increasing nitrate-nitrogen concentrations evident in all of the aquifers studied, an evaluation of current nitrogen management practices is needed. The following section uses two models to determine a nitrogen budget, model nitrogen leaching rates and determine a nitrogen loading rate for the West Coast. 


\subsection{CURRENT NITROGEN LEACHING}

Current concentrations of nitrate-nitrogen throughout the West Coast are below the New Zealand drinking water guideline of $11.3 \mathrm{~g} / \mathrm{m}^{3}$; however, elevated levels of nitrates are evident in all of the study bores of the Inangahua Valley/Reefton and Grey Valley areas and in two NGMP bores (Bertacco, Coleman). The NGMP bores also showed nitrate-nitrogen concentrations increasing significantly for the period 1998-2003.

The increasing trends evident in the Bertacco and Coleman bores suggest that nitrate leaching to groundwater is increasing. This could be due to a number of factors, including the increases in stocking rate, fertiliser use or the application of DSE to land.

Nitrogen fertiliser use has increased from average application rates of less than 50 $\mathrm{kgN} / \mathrm{ha} / \mathrm{yr}$ a decade ago (Bray pers comm., 2001) to average application rates of $100-130 \mathrm{kgN} / \mathrm{ha} / \mathrm{yr}$ in 2002 (LIC, 2003). In 2001, only $20 \%$ of dairy farms in the region were applying their DSE to land (WCRC, 2001). With land-based disposal of DSE now the preferred method of effluent disposal this percentage is likely to significantly increase in future years. While land-based application of DSE is designed to improve surface water quality the effects that this increase in DSE to land will have on groundwater quality needs to be carefully monitored and managed.

\subsection{THE NITROGEN LEACHING ESTIMATION (NLE) MODEL}

\subsubsection{Model Design}

The NLE model (Version 2.0; $\mathrm{Di}$ and Cameron, 2002) is a semi-empirical model designed to estimate nitrogen leaching losses and critical nitrogen application rates in dairy pasture systems. The concepts of the model are first described and then the model is used to calculate nitrogen leaching losses and nitrogen application rates for the 'typical' dairy farm in the Inangahua Valley/Reefton, Kowhitirangi and Grey Valley areas of the West Coast. 
The NLE model is based on the concept that the annual nitrogen leaching loss is related to the annual average amount of potentially leachable nitrogen in the soil and the annual drainage through the soil ( $\mathrm{Di}$ and Cameron, 2000). The annual average amount of potentially leachable nitrogen is determined through the sum of annual flux rates of the major nitrogen cycling processes ( $\mathrm{Di}$ and Cameron, 2000).

The annual flux rate used in the NLE model is calculated as:

$$
N_{P L}=N_{F}+N_{B}+N_{M}+N_{A}-N_{P}-N_{V}-N_{D}
$$

Where: $\quad N_{P L}=$ potentially leachable nitrogen $(\mathrm{kgN} / \mathrm{ha})$

$\mathrm{N}_{\mathrm{F}}=$ annual fertiliser or effluent nitrogen application rate

$\mathrm{N}_{\mathrm{B}}=$ annual biological fixation rate

$\mathrm{N}_{\mathrm{M}}=$ annual net nitrogen mineralisation

$\mathrm{N}_{\mathrm{A}}=$ annual animal nitrogen returns (mainly urine) to pasture

$\mathrm{N}_{\mathrm{P}}=$ annual pasture nitrogen uptake

$N_{V}=$ volatilization losses after the application of nitrogen fertilisers or effluents

$N_{D}=$ the denitrification loss

The effects on nitrogen leaching by drainage (calculated as annual rainfallevapotranspiration) are taken into account by normalising the annual nitrogen leaching loss to a per $100 \mathrm{~mm}$ drainage basis ( $\mathrm{Di}$ and Cameron, 2002). This is calculated assuming nitrogen leaching losses increase with drainage volume. Data entry into the model is through a simple Windows-based front end (Figure 6.2). 


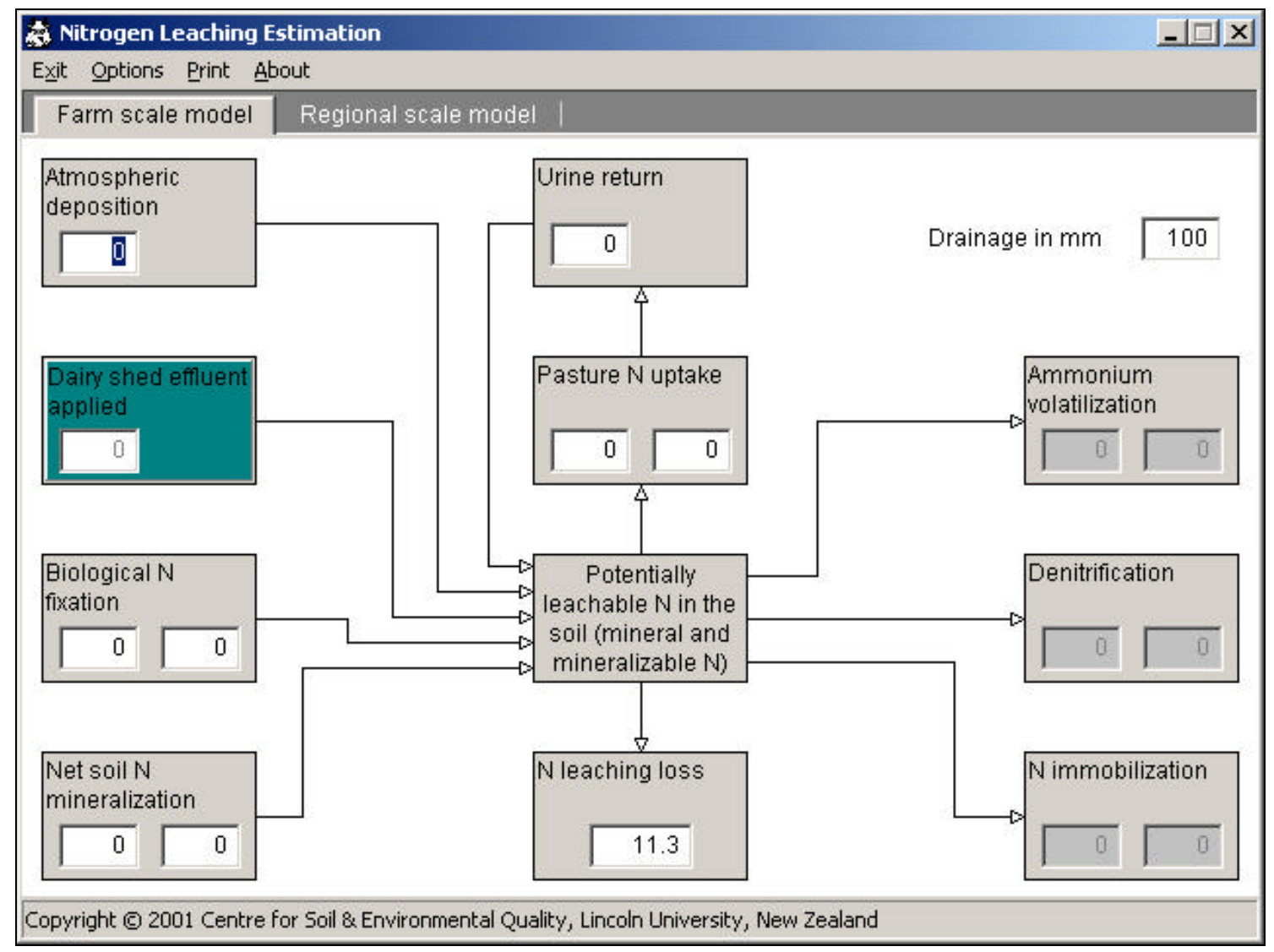

Figure 6.2: NLE data entry screen; Source: Di and Cameron, 2002.

\subsubsection{Model Options}

The model allows the option of calculating critical nitrogen application rates for mineral nitrogen fertiliser, dairy shed effluent, dairy pond sludge or pig slurry. The model also allows the option of calculating leaching losses and critical nitrogen application rates without the input of volatilisation and denitrification rates as data on these processes is often not available (Di and Cameron, 2002).

For this study, a number of scenarios were evaluated. At each study area (Kowhitirangi, Inangahua Valley/Reefton and Grey Valley), data inputs representative of a 'typical farm' are used. The model is used to determine the following outputs for the typical farm within each study area:

- the modeled nitrogen loading rates of mineral nitrogen fertiliser and dairy shed effluent (in $\mathrm{kgN} / \mathrm{ha}$ ) required for the groundwater to reach the levels of nitrate currently found in these areas; 
- the nitrogen loading rate of both mineral nitrogen fertiliser and dairy shed effluent (in $\mathrm{kgN} / \mathrm{ha}$ ) that can be applied before the nitrate leached reached the critical drinking water guideline of $11.3 \mathrm{~g} / \mathrm{m}^{3}$; and,

- the leaching losses (in $\mathrm{kgN} / \mathrm{m}^{3}$ ) of nitrogen under current effluent and nitrogen loading rates, and scenario effluent and nitrogen loading rates.

\subsubsection{Explanation of inputs used in the NLE}

\subsubsection{Fertiliser Use}

Nitrogen applications on the West Coast are between $100-130 \mathrm{kgN} / \mathrm{ha} / \mathrm{yr}$ of total mineral nitrogen (LIC, 2003). Nitrogen application are typically through the use of urea fertilisers which contain approximately $46 \%$ mineral nitrogen (Balance Agrinutrients, 2003). Based on this data from LIC the modeled total mineral nitrogen fertiliser use is set at $115 \mathrm{kgN} / \mathrm{ha} / \mathrm{yr}$ for all of the study areas.

\subsubsection{Drainage}

Drainage is calculated as mean annual rainfall - evapotranspiration (ET). ET rates were only available from the Reefton EWS site (mean annual ET 1999-2004 = $714 \mathrm{~mm}$; NIWA, 2004) and not from the Grey Valley or Kowhitirangi sites. With similar temperatures, sunshine hours and wind regime, rates of ET are assumed to be the same in the Grey Valley and Kowhitirangi areas as in the Inangahua Valley/Reefton area, hence the the drainage values used are Inangahua Valley $/$ Reefton $=740 \mathrm{~mm}$, Grey Valley $=941$ and Kowhitirangi $=2485 \mathrm{~mm}$.

\subsubsection{Atmospheric deposition}

Atmospheric deposition of nitrogen is small in New Zealand when compared to anthropogenic sources (Close et al., 2001; Di and Cameron, 2002). No measurements of atmospheric nitrogen deposition have been undertaken on the West Coast. Di and Cameron (2002) suggest using a default value of $5 \mathrm{kgN} / \mathrm{ha} / \mathrm{yr}$ when there is no available data. 


\subsubsection{Biological nitrogen fixation}

The amount of clover nitrogen fixation depends on temperature, moisture and soil fertility. It increases with warmer temperature and moist conditions, but decreases under high nitrogen application rates ( $\mathrm{Di}$ and Cameron, 2002). As the fixation of nitrogen through clover is the major nitrogen input into grazed pasture systems in New Zealand (assuming no fertiliser $\mathrm{N}$ application) careful consideration must be given to the estimation of nitrogen fixation rates. However, it is difficult to estimate biological nitrogen fixation for the West Caost due to the lack of data from the region.

Typical rates of nitrogen fixation of non urine patch areas in New Zealand pastures are between 50 and $300 \mathrm{kgN} / \mathrm{ha} / \mathrm{yr}$ (Balance Fertilisers, 2003; Di and Cameron, 2002). Selvarajah (1996) estimates the rate of nitrogen fixation of a typical Waikato pasture at $200 \mathrm{kgN} / \mathrm{ha} / \mathrm{yr}$ assuming no nitrogen fertiliser use. The West Coast has lower average annual temperatures (NIWA, 2003) and less fertile soils than the Waikato region (Almond pers. comm., 2003; Thorrold pers. comm., 2003) so lower rates of nitrogen fixation would be expected. For this study the model is run using two sets of data. Firstly a rate described as a medium nitrogen fixation rate (Di and Cameron, 2002) is used with the values of $150 \mathrm{kgN} / \mathrm{ha} / \mathrm{yr}$ for the non-urine patch area and $20 \mathrm{kgN} / \mathrm{ha} / \mathrm{yr}$ for the urine patch area. A low nitrogen fixation rate (Di and Cameron, 2002) is then used; that is, a value of $50 \mathrm{kgN} / \mathrm{ha} / \mathrm{yr}$ for the non-urine patch area and $10 \mathrm{kgN} / \mathrm{ha} / \mathrm{yr}$ for the urine patch area.

\subsubsection{Net soil nitrogen mineralisation}

The total amount of nitrogen released from the mineralisation of soil organic matter depends on soil conditions, in particular soil organic matter content (Di and Cameron, 2002) and environmental conditions (particularly, temperature and moisture; Di and Cameron, 2002). The amount of nitrogen typically released from New Zealand pastures varies from 100 to $400 \mathrm{kgN} / \mathrm{ha} / \mathrm{yr}$ and is generally equivalent to about $4 \%$ of the total organic nitrogen in the top $20 \mathrm{~cm}$ of soil (Di and Cameron, 2002). Data for soil organic nitrogen levels is scarce for West Coast soils. Work by Mew (1980) indicated medium to high ( $0.2 \%$ to $0.4 \%$ ) levels of nitrogen in the organic content of the soils in this study. Based on the data from Mew, a value of $200 \mathrm{kgN} / \mathrm{ha}$ is used for the Hokitika soils (Kowhitirangi), and a value of $300 \mathrm{kgN} / \mathrm{ha}$ for the Ahaura and Ikamatua soils (Grey Valley and Reefton). 


\subsubsection{Urine return}

The urine return is described as the net nitrogen returned under the urine patch. This is generally regarded to be $1000 \mathrm{kgN} / \mathrm{ha}$ for New Zealand Dairy cows (Di and Cameron, 2002; Selvarajah, 1996).

\subsubsection{Fractional area covered by urine}

Research has shown that the fractional area covered by urines patches is equivalent to about $8 \%$ of the grazed paddock per cow per annum ( $\mathrm{Di}$ and Cameron, 2002). Using this figure, the fractional areas covered by urine for the following areas are: Inanhahua Valley/Reefton at $2.18 \mathrm{cows} / \mathrm{ha}=0.17$, Grey Valley at $2.03 \mathrm{cows} / \mathrm{ha}=$ 0.16 and Kowhitirangi at $1.89 \mathrm{cows} / \mathrm{ha}=0.15$.

\subsubsection{Pasture nitrogen uptake}

The uptake by pasture of nitrogen can increase with increased application rates of nitrogen and is different for urine patch areas and the rest of the paddock ( $\mathrm{Di}$ and Cameron, 2000). While conditions on the West Coast may not be as favorable for pasture growth as New Zealand's northern and eastern regions are, conditions in recent years have provided better than average pasture growth (MAF, 2003). Pasture uptake of $\mathrm{N}$ is approximately $350 \mathrm{kgN} / \mathrm{ha}$ in the West Coast Region assuming an average pasture production rate of 10,000 kg/DryMatter/ha (Thorrold pers. comm., 2003) and a $\mathrm{N}$ content of pasture of around $3.5 \%$ on a dry weight basis.

\subsubsection{Results}

\subsubsection{Inangahua Valley/Reefton}

Under the low biological nitrogen fixation scenario, the modeled critical application rates required for the leached water to reach a concentration of $11.3 \mathrm{~g} / \mathrm{m}^{3}$ were above the current nitrogen application rates. Under the medium nitrogen fixation scenario, with higher inputs of nitrogen in the system, the critical application rate of nitrogen fertiliser was above the current level; however, the critical application rate for DSE was less than the current maximum of $275 \mathrm{kgN} / \mathrm{ha} / \mathrm{yr}$ (Table 6-2). 


\begin{tabular}{l|l|l|l|l} 
& \multicolumn{2}{|l|}{ Low biological N fixation } & Medium biological N fixation \\
\hline $\begin{array}{l}\text { Input Variables } \\
\mathbf{( k g N / h a )}\end{array}$ & $\begin{array}{l}\text { Urine patch } \\
\text { area }\end{array}$ & $\begin{array}{l}\text { Non-urine } \\
\text { patch area }\end{array}$ & $\begin{array}{l}\text { Urine patch } \\
\text { area }\end{array}$ & $\begin{array}{l}\text { Non-urine } \\
\text { patch area }\end{array}$ \\
\hline $\mathrm{N}$ fixed & 10 & 50 & 20 & 150 \\
\hline Soil N mineralised & 300 & 300 & 300 & 300 \\
\hline Urine N input & 1000 & 1000 & 1000 & 1000 \\
\hline Pasture N uptake & 600 & 350 & 600 & 350 \\
\hline
\end{tabular}

Critical application rate to reach $11.3 \mathrm{gN} / \mathrm{m}^{3}(\mathrm{kgN} / \mathrm{ha} / \mathrm{yr})$

\begin{tabular}{l|l|l}
\hline Fertiliser N & 204 & 149 \\
\hline DSE & 313 & 229 \\
\hline
\end{tabular}

Leaching loss under current nitrogen application rates $\left(\mathrm{g} / \mathrm{m}^{3}\right)$. Values in brackets are mean observed nitrate-nitrogen levels.

\begin{tabular}{l|l|l}
\hline $\begin{array}{l}\text { Fertiliser N (@ 115 } \\
\text { kgN/ha/yr) }\end{array}$ & $8.0(2.5)$ & $9.6(2.5)$ \\
\hline $\begin{array}{l}\text { DSE (@ 275 } \\
\text { kgN/ha/yr) }\end{array}$ & $10.1(2.5)$ & $12.6(2.5)$
\end{tabular}

Table 6-2: NLE model inputs and results for the Inangahua Valley/Reefton study area

Under the scenarios modeled as representative of current nitrogen application rates, the current leaching losses were under the drinking water guidelines for the low nitrogen fixation rates. Under medium fixation rates, fertliser leaching resulted in nitrate concentrations below the drinking water standard, but leaching from DSE applications resulted in nitrate-nitrogen concentrations exceeding the drinking water standard.

\subsubsection{Grey Valley}

Results for the Grey Valley scenarios were similar to those from the Inangahua Valley/Reefton area. The only input difference was in the drainage, which was greater for the Grey Valley, resulting in the model predicting higher rates of nitrate leaching. Under the low nitrogen fixation scenario, the modeled critical application rates required for the leached water to reach a concentration of $11.3 \mathrm{~g} / \mathrm{m}^{3}$ were above current application rates. Under the medium nitrogen fixation scenario, with higher inputs of nitrogen in the system, the critical application rate of nitrogen 
fertiliser was also above the current level; however, the critical application rate for DSE was less than the current maximum of $275 \mathrm{kgN} / \mathrm{ha} / \mathrm{yr}$ (Table 6-3).

\begin{tabular}{l|l|l|l|l} 
& \multicolumn{2}{|l|}{ Low biological N fixation } & Medium biological N fixation \\
\hline $\begin{array}{l}\text { Input Variables } \\
\mathbf{( k g / N / h a )}\end{array}$ & $\begin{array}{l}\text { Urine patch } \\
\text { area }\end{array}$ & $\begin{array}{l}\text { Non-urine } \\
\text { patch area }\end{array}$ & $\begin{array}{l}\text { Urine patch } \\
\text { area }\end{array}$ & $\begin{array}{l}\text { Non-urine } \\
\text { patch area }\end{array}$ \\
\hline $\mathrm{N}$ fixed & 10 & 50 & 20 & 150 \\
\hline Soil N mineralised & 300 & 300 & 300 & 300 \\
\hline Urine N input & 1000 & 1000 & 1000 & 1000 \\
\hline Pasture N uptake & 600 & 350 & 600 & 350 \\
\hline
\end{tabular}

Critical application rate to reach $11.3 \mathrm{gN} / \mathrm{m}^{3}(\mathrm{kgN} / \mathrm{ha} / \mathrm{yr})$

\begin{tabular}{l|l|l}
\hline Fertiliser N & 204 & 149 \\
\hline DSE & 313 & 229 \\
\hline
\end{tabular}

Leaching loss under current nitrogen application rates $\left(\mathrm{g} / \mathrm{m}^{3}\right)$. Values in brackets are mean observed nitrate-nitrogen levels.

\begin{tabular}{l|l|l}
\hline $\begin{array}{l}\text { Fertiliser N (@ 115 } \\
\text { kgN/ha/yr) }\end{array}$ & $8.1(2.5)$ & $9.7(2.5)$ \\
\hline $\begin{array}{l}\text { DSE (@ 275 } \\
\text { kgN/ha/yr) }\end{array}$ & $10.3(2.5)$ & $12.8(2.5)$
\end{tabular}

Table 6-3: NLE model inputs and results for the Grey Valley study area

Modeled results for the leaching losses under current application rates were also similar to those of the Inangahua Valley/Reefton area. The modeled current leaching losses were under the drinking water guidelines for the low nitrogen fixation rates. Under medium fixation rates, fertliser leaching losses were also below drinking water standard, but leaching from DSE applications was above the drinking water standard by $1.5 \mathrm{~g} / \mathrm{m}^{3}$.

\subsubsection{Kowhitirangi}

Results from the Kowhitirangi area differed from those of the Grey Valley and Inangahua Valley/Reefton areas, which produced results similar to each other. Because of the lower soil organic nitrogen levels in the Hokitika soils, lower rates of net soil nitrogen mineralisation were used. Significantly higher rates of drainage were also used due to the high rainfall the Kowhitirangi area receives. Under the low and 
medium nitrogen fixation scenarios, the modeled critical application rates required for the leached water to reach a concentration of $11.3 \mathrm{~g} / \mathrm{m}^{3}$ were all above current application rates (Table 6-4).

\begin{tabular}{l|l|l|l|l} 
& \multicolumn{2}{|l|}{ Low biological N fixation } & Medium biological N fixation \\
\hline $\begin{array}{l}\text { Input Variables } \\
\mathbf{( k g N / h a )}\end{array}$ & $\begin{array}{l}\text { Urine patch } \\
\text { area }\end{array}$ & $\begin{array}{l}\text { Non-urine } \\
\text { patch area }\end{array}$ & $\begin{array}{l}\text { Urine patch } \\
\text { area }\end{array}$ & $\begin{array}{l}\text { Non-urine } \\
\text { patch area }\end{array}$ \\
\hline N fixed & 10 & 50 & 20 & 150 \\
\hline Soil N mineralised & 200 & 200 & 200 & 200 \\
\hline Urine N input & 1000 & 1000 & 1000 & 1000 \\
\hline Pasture N uptake & 600 & 350 & 600 & 350 \\
\hline
\end{tabular}

\begin{tabular}{l|l|l}
\hline \multicolumn{2}{l|}{ Critical application rate to reach $\mathbf{1 1 . 3} \mathbf{~ g N / \mathbf { m } ^ { 3 }}$ (kgN//ha/yr) } \\
\hline Fertiliser N & 330 & 270 \\
\hline DSE & 508 & 414 \\
\hline
\end{tabular}

Leaching loss under current nitrogen application rates $\left(\mathrm{g} / \mathrm{m}^{3}\right)$. Values in brackets are mean observed nitrate-nitrogen levels.

\begin{tabular}{l|l|l}
\hline $\begin{array}{l}\text { Fertiliser N (@ 115 } \\
\mathrm{kgN} / \mathrm{ha} / \mathrm{yr})\end{array}$ & $5.2(0.8)$ & $5.5(0.8)$ \\
\hline $\begin{array}{l}\mathrm{DSE}(@ 275 \\
\mathrm{kgN} / \mathrm{ha} / \mathrm{yr})\end{array}$ & $6.2(0.8)$ & $7.4(0.8$
\end{tabular}

Table 6-4: NLE model inputs and results for the Kowhitirangi study area

Modeled results for the leaching losses under present day application rates were considerably lower than the results modeled for the Grey Valley and Inangahua Valley/Reefton areas, possibly reflecting the increased drainage in this area. Leaching loss concentrations for fertiliser nitrogen applications, and DSE nitrogen applications were below the drinking water guidelines under both the low and medium nitrogen fixation scenarios.

\subsection{THE OVERSEER MODEL}

\subsubsection{Model Design}

The OVERSEER nutrients budget model (AgResearch, 2003) is an empirical, annual time-step model (Ledgard et al., 1999). It is designed to calculate nutrient budgets 
(N, P, K, S) for either a block of a farm or the whole farm. The model allows the calculation of a nutrient budget for either a pastoral, horticultural or cropping scenario. The model has a number of internal databases with nutrient concentrations of fertilisers, climatic, soil and nutrient cycling information on which the model is based (AgResearch, 2003). Data entry into the OVERSEER model is through a simple Windows-based front end (Figure 6.3).

OVERSEER calculates nitrogen leaching rates by considering the amount of fertiliser nitrogen, farm dairy effluent and the nitrogen excreted in urine and dung by grazing animals. The latter is calculated from the difference between $N$ intake by grazing animals and $\mathrm{N}$ output in animal products, based on the user inputs of the stocking rate and milk production and an internal database with information on the $\mathrm{N}$ content of pasture and animal products (MAF, 2003).

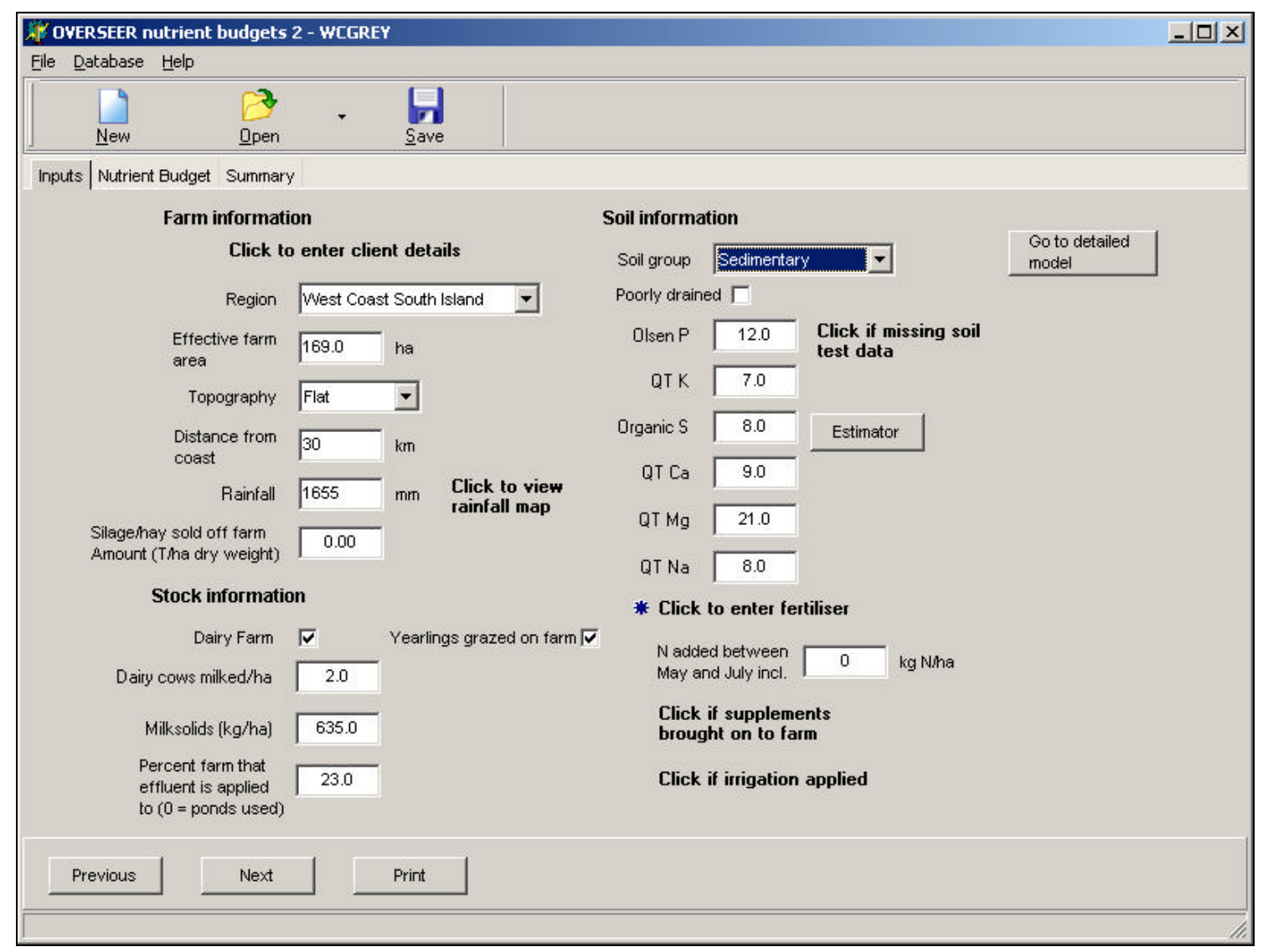

Figure 6.3: OVERSEER data entry screen; Source: AgResearch, 2003. 


\subsubsection{Model Options}

For this study, the 'Pastoral Express' function of the model is used. The 'Pastoral Express' function is used when a nutrient budget (in this case a nitrogen budget) is required for only one farm, or one block of a farm as opposed to the 'Detailed model' which allows comparisons of multiple blocks on the one farm.

As the model can be used to calculate a total nutrient budget, the option of entering soil fertility data $(\mathrm{P}, \mathrm{K}, \mathrm{S}, \mathrm{Ca}, \mathrm{Mg}, \mathrm{Na})$ is given. The aim of this study was to determine nitrogen leaching rates and therefore these values are not used for this modeling exercise.

The OVERSEER model is used to determine the nitrogen leached in the drainage water for the 'typical farm' in each of the study areas Inangahua Valley/Reefton, Grey Valley and Kowhitirangi. The data used to represent the 'typical farms' is given in the next section.

\subsubsection{Inputs used in the OVERSEER model}

Table 6-5 lists the input values were used to determine the nitrogen leaching loss for each area. The main differences between areas were in the farm characteristics such as farm size, milk production, cows per ha, fertiliser loading rates and effluent irrigation areas. 


\begin{tabular}{|c|c|c|c|c|}
\hline & $\begin{array}{l}\text { Inangahua } \\
\text { Valley/Reefton }\end{array}$ & Grey Valley & Kowhitirangi & Source \\
\hline $\begin{array}{l}\text { Effective Farm } \\
\text { Area (ha) }\end{array}$ & 125 & 169 & 135 & LIC, 2003 \\
\hline Topography & & Flat & Flat & \\
\hline $\begin{array}{l}\text { Distance from } \\
\text { Coast }(\mathrm{km})\end{array}$ & 60 & 30 & 30 & \\
\hline Rainfall (mm) & 1454 & 1655 & 3199 & $\begin{array}{l}\text { WCRC, } \\
2002 \\
\text { NIWA, } 2003\end{array}$ \\
\hline Cows milked/ha & 2.2 & 2.0 & 1.9 & LIC, 2003 \\
\hline Milksolids (kg/ha) & 676 & 635 & 602 & LIC, 2003 \\
\hline $\begin{array}{l}\text { Percentage of farm } \\
\text { effluent applied to }\end{array}$ & 32 (40ha) & 23 (40ha) & Ponds & \\
\hline Soil group & Sedimentary & Sedimentary & Recent & \\
\hline $\begin{array}{l}\text { Fertiliser loading } \\
\text { (kgN/ha) }\end{array}$ & 115 & 115 & 115 & LIC, 2003 \\
\hline $\begin{array}{l}\mathrm{N} \text { added between } \\
\text { May and July }\end{array}$ & 0 & 0 & 0 & \\
\hline
\end{tabular}

Table 6-5: OVERSEER inputs for the Inangahua Valley/Reefton, Grey Valley and Kowhtirangi study areas

\subsubsection{Results}

Three 'typical farm' scenarios were evaluated using the OVERSEER model. Results for the Reefton, Grey Valley and Kowhitirangi areas were as follows:

\begin{tabular}{l|c|c|c} 
& Reefton & Grey Valley & Kowhitirangi \\
\hline $\mathbf{N}$ leached kgN/ha & 32 & 32 & 47 \\
\hline $\begin{array}{l}\text { Average N concentration in } \\
\text { drainage water }\left(\mathbf{g} / \mathbf{m}^{3}\right)\end{array}$ & $5(2.5)$ & $3(2.5)$ & $2(0.8)$
\end{tabular}

Table 6-6: OVERSEER results for the Reefton, Grey Valley and Kowhtirangi study areas (bracketed values are mean observed nitrate-nitrogen concentrations) 
The results from the OVERSEER modeling scenarios gave considerably lower drainage water nitrogen concentrations than the NLE model gave (Table 6-2, Table 6-3, Table 6-4, Table 6-6). Results from the Grey Valley and Reefton areas were similar; however, the Kowhitirangi area had a higher nitrogen leaching total than the other areas, but a lower drainage water nitrogen concentration, possibly due to the higher rainfall in the area.

\subsection{DISCUSSION}

Prior to the discussion of the model outputs it is important to restate the current application and leaching rates. It is assumed that the current nitrogen fertiliser rates average $115 \mathrm{kgN} / \mathrm{ha} / \mathrm{yr}$ for all study sites. It is also assumed that those farms who apply effluent to land, apply it at the maximum $275 \mathrm{kgN} / \mathrm{ha} / \mathrm{yr}$. If the nitrogen application rates are treated as a single source of nitrogen, it is possible that rates of up to $390 \mathrm{kgN} / \mathrm{ha} / \mathrm{yr}$ are currently being applied. Current nitrate-nitrogen levels average $2.5 \mathrm{~g} / \mathrm{m}^{3}$ in the Inangahua Valley and Grey Valley areas, and $0.8 \mathrm{~g} / \mathrm{m}^{3}$ in the Kowhitirangi area.

\subsubsection{NLE}

Critical application rates determined by the NLE model were modeled under the low and medium nitrogen fixation scenarios. Under the low fixation scenario, there is a lower potential for nitrogen leaching due to less nitrogen being fixed by clover. The results from the Inangahua Valley, Grey Valley and Kowhitirangi areas suggested that in all cases, rates of nitrogen from fertiliser, or from DSE, higher than those currently being applied could be applied before the drainage water reaches the critical value of $11.3 \mathrm{~g} / \mathrm{m}^{3}$. Under the medium nitrogen fixation scenario, with more nitrogen entering the system, fertiliser and DSE application rates that could be applied before the drainage water reaches the critical values are lower than those of the low fixation scenario, and are above the currently applied rate for fertiliser $\mathrm{N}$. However, the modeled rates of critical DSE application in the Inangahua Valley and Grey Valley areas are lower than the $275 \mathrm{kgN} / \mathrm{ha} / \mathrm{yr}$ currently allowed.

If the currently applied rates of fertiliser nitrogen and DSE are treated as a single source of effluent, i.e a total nitrogen loading rate of up to $390 \mathrm{kgN} / \mathrm{ha} / \mathrm{yr}$, then under 
the low and high fixation scenarios for the Inangahua Valley and Grey Valley areas it is possible that current nitrogen application rates could result in the nitrate-nitrogen concentration of the drainage water exceeding $11.3 \mathrm{~g} / \mathrm{m}^{3}$. In the Kowhitirangi area, the modeled critical application rates were well above rates that could ever be expected to be applied. The high critical application rates in the Kowhitirangi area are due to the high drainage value $(>2485 \mathrm{~mm})$ used in the model. The high drainage rate has the effect of diluting nitrate-nitrogen concentrations, this is seen in the observed low mean nitrate-nitrogen concentration of $0.8 \mathrm{~g} / \mathrm{m}^{3}$.

Leaching losses of nitrate-nitrogen $\left(\mathrm{g} / \mathrm{m}^{3}\right)$ were evaluated using current application rates of fertiliser nitrogen and DSE. Overall, the modeled leaching losses were much higher than the observed leaching losses in all of the study areas. Considering the age of the water sampled is generally at least 7-12 years old (Chapter 5: Age Dating and Isotope Analysis) it is likely that the observed nitrogen concentrations are a reflection of nitrogen management practices that were occurring 7-12 years ago. This suggests the possibility that nitrate-nitrogen concentrations will increase in the future as increases in stocking rate, DSE application and fertiliser use have been greater in the past five years. If this is the case, then leaching losses under the low nitrogen fixation scenario, or the medium nitrogen fixation scenario could be expected to exceed the $11.3 \mathrm{~g} / \mathrm{m}^{3}$ critical value.

However, the validity of applying the model to the West Coast region, and the accuracy of the input values must be taken into consideration. While the input values have been determined to the most accurate level possible, given the lack of specific West Coast data, it could be expected that a high degree of error is involved. Di and Cameron (2002) suggest the most important parameters in the model are: pasture nitrogen uptake, soil nitrogen mineralisation and nitrogen fixation. Specific studies on these parameters need to be conducted on the West Coast to accurately determine actual and potential leaching losses.

Another issue is with the use of the model in high drainage situations. The model has only been calibrated to scenarios of up to $600 \mathrm{~mm}$ drainage. All of the West Coast sites have drainage values in excess of $600 \mathrm{~mm}$. Leaching losses from the NLE model are normalised to a per $100 \mathrm{~mm}$ drainage basis by dividing the annual 
recharge volumes $(\mathrm{mm})$ into the annual leaching losses. This takes into account the effects of high drainage on leaching loss, which while increasing the speed of leaching through the soil, actually decreases through dilution the concentration of nitrate-nitrogen leached.

Denitrification and volatilisation were excluded from this use of the NLE model as data for them was unavailable. Di and Cameron (2000) found the effects of excluding these processes to be negligible when tested on data from a number of Canterbury studies. Di and Cameron (2000) concluded that the equation for the relationship between nitrogen leaching loss and potentially leachable nitrogen used in the scenario without denitrification and volatilisation gives the same results as the equation that takes denitrification and volatilisation into consideration. Thus, the absence of these processes is deemed not to have a significant effect on the final output.

\subsubsection{OVERSEER}

The drainage water concentrations of nitrate-nitrogen derived from the OVERSEER model correlated more closely to the nitrate-nitrogen concentrations observed in this study. By using a more simple nitrogen balance concept, as opposed to the data intensive nitrogen process based approach of the NLE, the input values required by the OVERSEER model are easier to obtain. This meant that fewer assumptions about the input values were used to model nitrate leaching using the OVERSEER model. However, without access to the internal databases of the OVERSEER model, it was not know what internal assumptions were made.

The modeled concentrations of nitrate-nitrogen in the drainage water under the current nitrogen application rates were all below the critical drinking water standard of $11.3 \mathrm{~g} / \mathrm{m}^{3}$. Considering that the observed values are likely to be a reflection of past landuse practices, the slightly higher than observed values given by the OVERSEER model are likely to be realistic values. The results suggest than in 7-12 years time, when the full effects of current DSE and fertiliser applications are leached into groundwater, nitrate-nitrogen concentrations will not exceed drinking water guidelines. 
While the OVERSEER nutrient budget model may not calculate nitrogen leaching based on the complex nitrogen flux processes (such as mineralisation, fixation, denitrification) that the NLE model uses, the results gained from it in this study have a lower source of error than the NLE model outputs. The nitrogen balance approach used in the OVERSEER model is similar to that used by Selvarajah (1996) who calculated a nitrogen loading rates for the Waikato region. It is believed to be an effective way of determining nitrate leaching losses in situations where adequate soil and groundwater information is not available (Selvarajah, 1996).

\subsubsection{Critical application rates}

One of the aims of this study was to evaluate the existing $275 \mathrm{kgN} / \mathrm{ha} / \mathrm{yr}$ application rate and, if possible, determine a new nitrogen loading rate based on data derived from a nitrogen budget/balance approach.

According to the results from the NLE model, critical application rates for DSE of up to $313 \mathrm{kgN} / \mathrm{ha} / \mathrm{yr}$ for the Inangahua Valley and Grey Valley areas, and up to 508 $\mathrm{kgN} / \mathrm{ha} / \mathrm{yr}$ for the Kowhitirangi area could be sustained assuming the scenario of low clover nitrogen fixation. Critical application rates of fertiliser under the low fixation scenario are $204 \mathrm{kgN} / \mathrm{ha} / \mathrm{yr}$ for the Grey and Inangahua Valleys and $330 \mathrm{kgN} / \mathrm{ha} / \mathrm{yr}$ for the Kowhitirangi area. Application rates exceeding these levels would result in the nitrate-nitrogen concentration reaching the critical level of $11.3 \mathrm{~g} / \mathrm{m}^{3}$.

If the scenario of medium clover fixation is assumed, then the modeled DSE application rates of $229 \mathrm{kgN} / \mathrm{ha} / \mathrm{yr}$ for the Inangahua Valley and Grey Valley areas are below the current maximum, suggesting the potential for the groundwater to reach the critical nitrate-nitrogen level. Under the medium clover fixation scenario the Kowhitrangi areas modeled DSE application rate is well above the current level at $414 \mathrm{kgN} / \mathrm{ha} / \mathrm{yr}$. Assuming that the low clover fixation scenario holds true, current the current DSE application rates are sustainable; however, if the medium clover fixation scenario holds true, then a lower DSE application rate of $229 \mathrm{kgN} / \mathrm{ha} / \mathrm{yr}$ would need to be adopted. Fertiliser nitrogen application rates are only just above the existing level of $115 \mathrm{kgN} / \mathrm{ha} / \mathrm{yr}$ at $149 \mathrm{kgN} / \mathrm{ha} / \mathrm{yr}$ for the Grey and Inangahua Valley and 270 $\mathrm{kgN} / \mathrm{ha} / \mathrm{yr}$ for the Kowhitirangi area. However, given the lack of accurate data 
available for entry into the model, the potential errors involved with the outputs of the model make it difficult to draw any firm conclusions.

The average nitrate-nitrogen concentrations in drainage water for the three 'typical' farm scenarios from the OVERSEER model were all below the national drinking water standard. The results from these scenarios suggest the current nitrogen application rate is safely managing nitrogen levels on the West Coast.

\subsection{CONCLUSIONS}

The monitoring of 19 study bores and analysis of results from two NGMP bores suggests that nitrate leaching from dairy farms is occurring on the West Coast and that significant increasing trends are evident. Given the increasing number of farms applying their DSE to land is important to evaluate current management practices. The current DSE nitrogen loading rate of $275 \mathrm{kgN} / \mathrm{ha} / \mathrm{yr}$ set by the WCRC is high compared to other New Zealand regional councils. This rate was therefore evaluated using two nitrogen leaching models, OVERSEER and NLE.

Results from the NLE model suggest that the current DSE application rate of 275 $\mathrm{kgN} / \mathrm{ha} / \mathrm{yr}$ is sustainable (assuming no fertiliser nitrogen input) if low biological nitrogen fixation rates are assumed, but is too high if higher levels of biological fixation are assumed. Given the lack of West Coast specific data needed for the NLE model no firm conclusions from the model outputs can be made. More accurate data, specific to the West Cost region, is needed for biological nitrogen fixation, soil mineralisation, pasture nitrogen uptake and rates of denitrification and volatilisation. Access to this data would allow a more comprehensive evaluation of the current nitrogen loading rate using the NLE model.

Given the accuracy of the data input into the OVEERSEER model, the results are likely to be more valid for the West Coast region. The OVERSEER model accounts for both the current DSE application rate and nitrogen fertiliser application rates. However, with-out access to the internal databases and equations that the model is based on, a cautious approach must be taken to making conclusions. Thus, based on the results from the OVERSEER model, the current nitrogen loading rate for DSE 
of $275 \mathrm{kgN} / \mathrm{ha} / \mathrm{yr}$ is likely to be environmentally sustainable, given the current stocking levels and fertiliser use.

The NLE model calculates nitrogen leaching rates based on detailed information that is used to calculate the annual rates of nitrogen flux processes in the soil-plant system. Using NLE model to determine sustainable nitrogen application rates would give more accurate results than using the OVERSEER model, which is based on a simple nitrogen balance model. However, due to the lack if detailed information, it is hard to reach conclusions based on the NLE outputs until more accurate data is collected in the future. It is therefore likely, based on the results from the OVERSEER model, that the current rates of DSE application will not result in nitrate-nitrogen levels reaching the critical concentration of $11.3 \mathrm{~g} / \mathrm{m}^{3}$. 


\section{SUMMARY AND CONCLUSIONS}

The West Coast region of the South Island, like the rest of New Zealand, has seen a rapid intensification of dairy farming in the past decade. The West Coast region now has $2.9 \%$ of the nation's herds with an average stocking rate of 2.03 cows/ha (LIC, 2003). Like most regional councils in New Zealand, the West Coast Regional Council (WCRC) promotes the application of dairy shed effluent (DSE) to land to manage and maintain surface water quality. The effects on groundwater quality from land-based application of DSE were investigated through the monitoring of 19 bores selected primarily for this study, and three National Groundwater Monitoring Programme (NGMP) bores.

By monitoring the selected bores for nitrate-nitrogen $\left(\mathrm{NO}_{3}-\mathrm{N}\right)$, ammonium-nitrogen $\left(\mathrm{NH}_{4}-\mathrm{N}\right)$, chloride $(\mathrm{Cl})$, iron $(\mathrm{Fe})$, dissolved reactive phosphorus (DRP), faecal coliforms and E. coli, the effects of dairy farming practices on groundwater quality on the Inangahua Valley/Reefton, Grey Valley and Kowhitirangi study areas were investigated. Groundwater quality in these areas was generally high and within the relevant Ministry of Health drinking water guidelines. However, in some study bores, levels of Iron and bacteria were found to be above the drinking water standards, and elevated concentrations of $\mathrm{NO}_{3}-\mathrm{N}$ were evident.

Concentrations of DRP were very low in all of the study bores, suggesting phosphorus based fertilisers were not affecting groundwater quality. However, New Zealand soils tend to have a high capacity for phosphorus adsorption and it is therefore unlikely for phosphorus levels to be high. Iron concentrations were highest in the Johnson bore located in the Ahaura Valley and were attributed to the reducing conditions of the groundwater in this bore, but were low in all of the other study bores. Ammonium-nitrogen concentrations were low in all of the study bores, as expected in shallow groundwaters.

The occurrence of microbial contamination was found to be both spatially and temporally independent in all cases except for the Ross farm bore. Counts of E. coli were found in three of four samples taken at this site. Microbial contamination of this 
bore was attributed to poor effluent management practices, that is a farm drain filled with effluent only $4 \mathrm{~m}$ from the bore. In most cases of microbial contamination, it is likely that poor effluent management practices are the cause.

Analysis of data from $1998-2003$ from the NGMP bores allowed the investigation of long-term trends that was not possible in the study bores. Samples from both the Bertacco, and Coleman bores, indicate significant trends of increasing nitratenitrogen and chloride. Both of these analytes can indicate the presence of sewage or effluent contamination, and in the case of nitrate-nitrogen, fertiliser contamination. Mann-Kendall trend analysis, and Sen's slope estimations, suggest significant increasing concentrations of nitrate-nitrogen in the Bertacco bore of $0.41 \mathrm{~g} / \mathrm{m}^{3} / \mathrm{yr}$, and in the Coleman bore of $0.13 \mathrm{~g} / \mathrm{m}^{3} / \mathrm{yr}$. Chloride concentrations have been increasing in the Bertacco bore at $0.50 \mathrm{~g} / \mathrm{m}^{3} / \mathrm{yr}$, and in the Coleman bore at $0.22 \mathrm{~g} / \mathrm{m}^{3} / \mathrm{yr}$. Given that the landuse surrounding the Bertacco and Coleman bores is similar to the other study areas, it is likely that elevated levels of nitrate-nitrogen and chloride found in the other study bore are increasing at similar rates.

Nitrogen isotope analysis was used to help determine the source of the nitratenitrogen observed in the groundwater in six bores in the Inangahua and Grey Valleys. These bores had an average $\delta^{15} \mathrm{~N}$ value of $3.5 \%$. The determined isotopic ratios suggest that the nitrate in the unconfined aquifers of Grey and Inangahua Valley areas was likely to be from either a fertiliser or soil organic nitrogen source rather than a human or animal effluent source. However, the strong increasing trends of nitrate-nitrogen and chloride in the Bertacco and Coleman bores suggest that effluent, as well as fertiliser nitrogen is contributing to the increase in nitratecontamination up-gradient of these bores.

Age dating of the groundwater, using CFCs, has shown that water in the unconfined aquifers of the Kowhitirangi area is approximately 8 years old and in the Grey Valley area it is approximately 12 years old. The relatively young age water is a factor of the high rainfall, high transmissivities and steep hydraulic gradients that dominate the geology of the study areas. Intensification of landuse practices over the past decade (such as an increase in stocking rates, more farms applying DSE to land and increased use of nitrogen fertilisers) has increased the potential for contaminants to 
leach from the soil into groundwater. The age of the groundwater suggests that the effects of this intensification are just starting to become evident in the groundwater quality, or are yet to reach the groundwater.

\subsection{NITROGEN MANAGEMENT}

Compared to other regional councils in New Zealand, the maximum DSE nitrogen loading rate of $275 \mathrm{kgN} / \mathrm{ha} / \mathrm{yr}$ as set by the WCRC is high. One of the aims of this study was to evaluate the sustainability of this loading rate given the evidence of increasing trends in nitrate-nitrogen over the region.

Data specific to the West Coast region quantifying nitrogen flux processes (such as pasture nitrogen uptake, biological nitrogen fixation, net soil mineralisation of nitrogen, denitrification, volatilisation) was found to be scarce. It was beyond the scope of this study to investigated these processes; however, given the limited data availability, an attempt using data adapted from previous research nitrate leaching losses were modeled using the NLE and OVERSEER models.

Scenarios for the 'typical' farm in the Inangahua Valley, Grey Valley and Kowhitirangi area were evaluated in the NLE model. The model suggested that current application rates of DSE nitrogen were sustainable and that the loading rate could be increased without nitrate-nitrogen concentration exceeding the $\mathrm{MoH}$ drinking water standard. However, the model has not been tested on areas where the total drainage volume exceeds $600 \mathrm{~mm}$, and without detailed nitrogen flux process information a cautious approach was taken in concluding any results from this model.

The OVERSEER model is based on a nitrogen budget balance model which users simpler inputs. Accurate data was available for all of the input variables. Results from the OVERSEER model suggested that under current nitrogen management practices the nitrate-nitrogen concentration in drainage water would not exceed the $\mathrm{MoH}$ drinking water standard. Thus, the model implies that the current DSE nitrogen loading rate is sustainable (given the $\mathrm{MoH}$ drinking water standard is the measure of sustainability). However, the validity of the assumptions made by the model and its applicability to the West Cost region are unknown. 
While the OVERSEER model took into account both the current DSE nitrogen and fertiliser nitrogen application rates, the issue of managing fertiliser nitrogen application rates is still valid. Even though current application rates may be sustainable, without a specific limit on the fertiliser application rate, future management will be difficult.

Given the results from both the NLE and OVERSEER models, it is still important that ongoing monitoring of nitrate-nitrogen levels occurs. With the full effects of the last 510 years of landuse intensification yet to reach groundwater, it is expected that nitrate-nitrogen and chloride levels will continue to increase.

As farmers continue to strive for higher milk yields, nitrogen inputs are commonly increased, even though current nitrogen inputs may be enough and all that is needed is a change in management practices. The increased nitrogen input is generally sourced from greater pasture production. Greater pasture production is gained from increased irrigation or increased fertiliser use. It is therefore important that correct management tools for fertiliser application are in place.

The current management regime of allowing any rate of fertiliser application is likely to be unsustainable in the future. Isotope analysis suggests that much of the nitratenitrogen found in this study is fertiliser sourced. While modeling has shown that current rates of $115 \mathrm{kgN} / \mathrm{ha}$ maybe sustainable it is likely that that rates of nitrogen fertiliser application will increase in the future as farmers try to increase production. Monitoring future increases in nitrogen fertiliser increases is important to aid management of groundwater quality in the future, especially when the effects of the fertiliser sourced nitrogen are combined with DSE nitrogen. 


\subsection{RECOMMENDATIONS}

One of the aims of this study was to expand the current spatial spread of groundwater quality information in the West Coast region. Nineteen new bores were monitored as part of this study. It is recommended that:

- The current groundwater quality monitoring programme be expanded to include some of the bores that showed elevated levels of nitrate-nitrogen and chloride in areas not currently monitored. For example: Beggs farm or Wilson residence in Totara Flat, Robinson farm in Kowhitirangi and Parkinson farm in Reefton. It may also be prudent to consider investigating groundwater quality in areas in the south and north of the region.

Due to the limited resources available during the study is was not possible conduct nitrogen isotope analysis and CFC dating in all of the study bores. As the NGMP bores have long lengths of record, supplementing this data with additional analysis would be beneficial. Conducting nitrogen isotope analysis on the Bertacco and Coleman bores, which show significant increasing trends in $\mathrm{NO}_{3}-\mathrm{N}$ and $\mathrm{Cl}$ would be beneficial in aiding the future management of nitrogen in the region. i.e. it is recommended that:

- nitrogen isotope analysis be conducted on all of the NGMP bores that show increasing trends of nitrate-nitrogen

In addition to nitrogen isotope analysis, limited resources were available for the CFC dating. To aid in the interpretation of the data records from the NGMP bores, it is recommended that:

- age dating, through both $C F C$, Tritium or $\mathrm{SF}_{6}$ analysis, be conducted on all of the NGMP bores

Research into the hydrogeology of the region noted that detailed information on transmissivities and hydraulic conductivity's of the West Coast aquifers is nonexistent. Currently farmers are not required, and are therefore reluctant, to conduct 
full pump-tests on their bores. While groundwater allocation is currently not an issue on the West Coast, it is possible that in the future pressures on this resource will increase, especially if the patterns of resource demand follow those that have occurred elsewere in New Zealand. Optimal management of the groundwater resource requires information on the extent and flow pathways of the resource. Detailed information on transmissivity and hydraulic conductivity values can also aid the interpretation of contaminant flow paths. While attempts were made to determine transmissivities using simple drillers' test data, the errors involved in the calculations were large. It is therefore recommended that:

- future investigation of transmissivities in the higher use aquifers, such as the Ahaura Valley, are carried out through pump testing

With limited West Coast specific data available for the evaluation of the current DSE nitrogen loading rate, a cautious approach must be taken prior to concluding that the current landuse practices are sustainable at the current rate. Given the results from the OVERSEER model is it suggested that the current rate of $275 \mathrm{kgN} / \mathrm{ha} / \mathrm{yr}$ maybe sustainable. However, it is recommended that:

- Accurate data on the nitrogen flux processes of pasture nitrogen uptake, biological nitrogen fixation, net soil mineralisation of nitrogen, denitrification and volatilisation are obtained through future research and a more detailed model, such as the NLE, is used to re-assess the nitrogen loading rate.

Land application of DSE is currently recognised as the environmentally the most sustainable option; however, just setting a nitrogen loading rate is not enough. Evidence of poor effluent management practices were noted at most sites during this study. While compliance monitoring is designed to enforce effluent management practices, the reality of a large spatial spread of farms, and low regional council staff numbers, means the potential for poor effluent management practices to get away un-noticed is higher than in other regions.

As with most environmental issues, greater education on both the effects of poor nitrogen management, and the benefits of good nitrogen management is needed. It 
was observed during the course of the study that although many farmers were applying their effluent to land through a travelling irrigator, little attention was paid to application rates and depths. It is recommended that:

- Tools, such as Environment Waikato's on-line Effluent Application Depth, and Effluent Application Rate calculators are developed as simple yet effective ways of providing farmers with the tools necessary for correct nitrogen management practices and would go a long way in helping solve West Coast nitrogen issues.

The West Coast region is set apart from other regions with its great natural resources; it must therefore be ensured that environmental management maintains and enhances these resources. However, this management must not be too restrictive and must still allow farmers scope to develop and innovate. Presently the West Coast region does not have the same level of problems from landuse practices that other areas have, and therefore it is important that this environmental position is maintained. 


\section{REFERENCES}

Agresearch. 2002. OVERSEER User Manual. Agresearch Ruakura, Hamilton.

AgResearch. 2003. OVERSEER Nutrient Budgets 2 - software for nutrient budgeting and environmental reports. AgResearch Ruakura, Hamilton.

Almond, P. 2003. Personal communication. Peter Almond, Soil and Physical Sciences Group, Lincoln University.

Australian and New Zealand Environment and Conservation Council. 2000. Australian and New Zealand guidelines for fresh and marine water quality, Volume 1 - The Guidelines.

Balance Agri-Nutrients, 2003. Nutrient Handbook. [online]: http://www.balance.co.nz/thbook.html

Barber, H.L. and Wilson, A.T. 1972. Nitrate pollution of groundwater in the Waikato Region. Chemistry in New Zealand, 36(6), 179-183.

Barkle, G.F., Stenger, R., Singleton, P.L. and Painter, D.J. 2000. Effect of regular irrigation with dairy farm effluent on soil organic matter and soil microbial biomass. Australian Journal of Soil Research, 38, p1087-1097.

Begg, R. 2001. Personal communication. Russel Begg, dairy farmer, Totara Flat, Westland.

Bohlke, J.K. and Denver, J.M. 1995. Combined use of groundwater dating, chemical, and isotopic analyses to resolve the history and fate of nitrate contamination in two agricultural watersheds, Atlantic coastal plain, Maryland. Water Resources Research, 31(9), p 2319-2339.

Bramwell, C. 2000. An Evaluation of the Sources and Controls of Nitrate Contamination in the Lake Horowhenua Area. Unpublished MSc Honours dissertation, Victoria University of Wellington.

Bray, J. 2001. Personal communication. John Bray, Dairy Farmer, Ahaura Valley, Westland.

Bull, R. 2001. Personal communication. Robin Bull, Dairy Farmer, Ahaura Valley.

Burden, R.J. 1982. Nitrate Contamination of New Zealand Aquifers: a review. New Zealand Journal of Science. 25(3): 205-220.

Butcher, G. 1996. Groundwater Resources of the Lower Wairarapa Valley. Report prepared for the Wellington Regional Council by Professional Groundwater and Environmental Services. 
Clark, I.D. and Fritz, P. 1997. Environmental Isotopes in Hydrology. Lewis Publishers, New York.

Close, M.E., Rosen, M.R. and Smith, V.R. 2001. Fate and Transport of nitrates and pesticides in New Zealand's aquifers. In: Groundwaters of New Zealand (Eds: Rosen, M.R. and White, P.A.), New Zealand Hydrological Society. Caxton Press, Christchurch.

Comly, H.H. 1945. Cyanosis in infants caused by nitrates in well water. Journal of the American Medical Association, 29, p 112-116.

Daugney, C.J. 2004. Personal Communication, Chris Daughney, Geochemist, Institute of Geological and Nuclear Sciences, Wellington.

Daughney, C.J. and Reeves, R. 2003. Definition of hydrochemical facies for New Zealand's groundwaters using data from the National Groundwater Monitoring Programme. Institute of Geological \& Nuclear Sciences science report 2003/18.

Davies, H. 2001. Groundwater and Health. In: Groundwaters of New Zealand (Eds: Rosen, M.R. and White, P.A.), New Zealand Hydrological Society. Caxton Press, Christchurch.

Di, H.J., Cameron, S., Smith, N.P. 1998. Nitrate leaching and pasture yields following the application of dairy shed effluent or ammonium fertiliser under spray or flood irrigation: results of a lysimeter study. Soil Use and Management (1998)14, p 209214.

Di, H.J., Cameron, S. 2000. Calculating Leaching losses and critical nitrogen application rates in dairy pasture systems using a semi-emperical model. New Zealand Journal of Agricultural Research, 43, p 139-147.

Di, H.J., Cameron, S. 2002. A Semi-Emperical Model for Estimating Nitrogen Losses and Critical Nitrogen Application Rates in Dairy Pasture Systems (Version 2.0). Centre for Soil and Environmental Quality, Lincoln University.

Driscoll, F.G. 1986. Groundwater and Wells, $2^{\text {nd }}$ Ed. Johnson Division, St. Paul, Minnesota.

Dunkle, S.A., Plummer, L.N., Busenberg, E., Phillips, P.J., Denver, J.M., Hamilton, P.A., Michel, R.L. and Coplen, T.B. 1993. Chlorofluorocarbons (CCl3F and CCI2F2) as dating tools and hydrogeologic tracers in shallow groundwater of the Delmarva Peninsula, Atlantic Coastal Plain, United States. Water Resources Research, 29(12), p 3837-3860.

Environment Bay Of Plenty. 2004. The Rotorua Lakes. [online]:

http://www.envbop.govt.nz/Water/Lakes/Lake-Action.asp 
Freeze, R.A and Cherry, J.A. 1979. Groundwater. Prentice-Hall, New Jersey.

Galligan. 2001. Personal communication. Galligan, Resident of Ahaura Valley, Westland.

Geological and Nuclear Sciences (Institute of). 2002. Geology of the Greymouth area - 1:250,000, QM12. Simon Nathan, M.S. Rattenbury, R.P. Suggate (compilers).

Gilbert, R.O. 1987. Statistical Methods for Environmental Monitoring. Van Nostrand Reinhold, New York.

Hanson, C.R. 2002. Nitrate concentrations in Canterbury Groundwater - a review of existing data. Environment Canterbury Report No.R02/17.

Hoare, R.A. and Rowe, L.K. 1992. Water Quality in NZ. In: Waters of New Zealand (Ed: Mosley, M.P), New Zealand Hydrological Society, Wellington.

Holden W S. 1970. (Ed): Water treatment and Examination. The Society for Water Treatment and Examination. J. \& A. Churchill, London.

Intelligent Decisions Technologies. 1998. WQStat Plus. Intelligent Decisions Technologies Ltd, Colorado, USA.

James, T. 2001. Chapter 24: West Coast Groundwater. In: Groundwaters of New Zealand (Eds: Rosen, M.R. and White, P.A.), New Zealand Hydrological Society. Caxton Press, Christchurch.

Jarvis, S.C. 1993. Nitrogen cycling and losses from dairy farms. Soil use and Management, 9(3), p 99-105.

Jarvis, S.C.1999. Nitrogen Dynamics in Agricultural Ecosystems. In: Managing Risks of Nitrate to Humans and the Environment (Eds: Wilson, W. S., Ball, A. S. and Hinton, R. H.) Royal Society of Chemistry, Cambridge

Kellman, M.L. and Hillaire-Marcel, C. 2002. Evaluation of nitrogen isotopes as indicators of nitrate contamination sources in an agricultural watershed. Agriculture Ecosystems and Environment, 95(2003), p 87-102.

Kruseman, G.P and de Ridder, N.A. 1970. Analysis and Evaluation of Pump Test Data, $1^{\text {st }}$ Ed. International Institure for Land Reclamation and Improvement, Netherlands.

Kruseman, G.P and de Ridder, N.A. 1994. Analysis and Evaluation of Pump Test Data, $2^{\text {nd }}$ Ed. International Institure for Land Reclamation and Improvement, Netherlands.

Livestock Improvement Corporation Limited. 2001. Dairy Statistics 2000-2001. Livestock Improvement Corporation Limited, Hamilton. 
Livestock Improvement Corporation Limited. 2003. Dairy Statistics 2002-2003. Livestock Improvement Corporation Limited, Hamilton.

Ledgard, S.F., Thom, E.R., Singleton, P.L.., Thorrold, B.S. and Edmeades, D.C. 1996. Environmental Impacts of Dairy Systems. [online]:

http://www.dexcel.co.nz/pdf files/rfc 1996/rfc96 led.pdf. Agresearch Ruakura, Hamilton.

Ledgard, S.F, Williams, P.H, Broom, F.D, Thorrold, B.S, Wheeler, D.M. and Willis, V.J. 1999: OVERSEERTM * a nutrient budgeting model for pastoral farming, wheat, potatoes, apples and kiwifruit. In: Best soil management practices for production. (Eds. Currie, L.D., Hedley, M.J., Horne, D.J. and Loganathan, P). Occasional report No. 12. FLRC, Massey University, Palmerston North. pp. 143-152.

McLarin, W., Bekesi, G., Brown, L. and McConchie, J. 1999 Nitrate contamination of the unconfined aquifer, Manakau, Horowhenua, New Zealand. Journal of Hydrology (New Zealand) 38(2), p 211-235.

McCleery, B. 2001. Personal communication. Brian McCleery, share-milker, Totara Flat, Westland.

Mills, R. 2001. Personal communication. Roger Mills, Dairy Farmer, Ahaura Valley.

Misstear, B. Logan Method for analysing pumping test data. [online]: http://www.gsi.ie/workgsi/groundwater/newslet/34/34-03.htm. Department of Civil, Structural and Environmental Engineering, TCD.

Mears, 2003. Personal communication, Ken Mears, Westmere Drilling, Greymouth.

Mew, G. 1980. Soils of Greymouth - Hokitika region, South Island, New Zealand. . N.Z Soil Survey Report 58. New Zealand Soil Bureau, Wellington.

Ministry of Agriculture and Forestry. 2000. Implications of Groundwater Nitrate Standards for Agricultural Management. Technical Paper 2000/15. MAF Policy, Wellington.

Ministry of Agriculture and Forestry. 2001. West Coast Farm Monitoring Statistics. [online]: $\quad$ http://www.maf.govt.nz/mafnet/rural-nz/statistics-and-forecasts/farmmonitoring/dairy-2001/dairy-2001-11.htm\#P1472 106949. MAF, Wellington.

Ministry of Agriculture and Forestry. 2002. West Coast Farm Monitoring Statistics. [online]:http://www.maf.govt.nz/mafnet/rural-nz/statistics-and-forecasts/farmmonitoring/2002/dairy/dairy-2002-09.htm\#P1939 106590. MAF ,Wellington.

Ministry of Agriculture and Forestry. 2003. The OVERSEER Nutrient Budget Model and Estimates of $\mathrm{N}$ Leaching. [online]: http://www.maf.govt.nz/mafnet/ruralnz/sustainable-resource-use/resource-management/nutrient-budgets/nutrientbudgets06.htm 
Ministry for the Environment, 1999. Resource Management Act - Practice and Performance: A case study of farm dairy effluent management. Ministry for the Environment, Wellington.

Ministry of Health, 2000. Drinking Water Standards for New Zealand 2000. Ministry of Health, Wellington, New Zealand.

Molloy, L. 1998. Soils in the New Zealand Landscape - the Living Mantle. New Zealand Society of Soil Science, Lincoln.

National Institute of Water and Atmospheric Research (NIWA). 2002. Climate Statistics, National Climate Database. NIWA, Wellington.

National Institute of Water and Atmospheric Research (NIWA). 2003. Climate Statistics, National Climate Database. NIWA, Wellington.

Parkinson, A. 2001. Personal communication. Alan Parkinson, Dairy farmer, Reefton, Westland.

Plummer, L.N. and Busenberg, E. 2000. Chlorofluorocarbons. In: Environmental tracers in subsurface hydrology (Eds: Cook, P.G. and Herczeg, A.L.). Kluwer Academic, Boston.

Roberts, A. 1997. Why is Fertiliser Resquired? AgResearch AgFact Sheet no.126. Ruakura Research Centre, Hamilton.

Rosen, M.R. 2001a. Assessment of Groundwater Quality in the West Coast Regional Council State of the Environment Monitoring Programme. Institute of Geological and Nuclear Sciences Client Report.

Rosen, M.R. 2001b. Hydrochemistry of New Zealand's Aquifers. In: Groundwaters of New Zealand (Eds: Rosen, M.R. and White, P.A.), New Zealand Hydrological Society. Caxton Press, Christchurch.

Ryden, J.C., Ball, P.R. and Garwood, E.A. 1984. Nitrate leaching in grassland. Nature, 311, p 50-53.

Selvarajah, N. 1996. Determination of Sustainable Nitrogen Loading Rates for Treatment Systems Without Adequate Soil and Ground Water Information: Dairy Farm Effluent Application onto Grazed Pasture in the Waikato Region. In Recent Developments in Understanding Chemical Movements in Soil (Eds: Currie, L.D. and Loganathan, P), Occasional Report 9. Fertilizer and Lime Research Centre, Massey University, Palmerston North.

Silva, R.G. 1999. Effect of urinary nitrogen, dairy shed effluent and nitrogen fertiliser on nitrate leaching from a pasture soil. A thesis submitted in partial fulfillment of the requirements fot the degree of Doctor of Philosophy in Soil Science at Lincoln University. 
Sinton, L.W. 2001. Microbial Contamination of New Zealand's Aquifers. . In: Groundwaters of New Zealand (Eds: Rosen, M.R. and White, P.A.), New Zealand Hydrological Society. Caxton Press, Christchurch.

SPSS Inc. 2000. SYSTAT Version 10 - statistical software.

Thorrold, B. 2003. Personal communication. Bruce Thorrold, Science Leader, Dexcel.

Van der Raaij, R. 2000. Nitrate Contamination in the Te Ore Ore Aquifers: A Study Using Chemical, Isotopic and CFC Data. Unpublished BSc Honours dissertation, Victoria University of Wellington.

Vant, W. 2003. Changes at Lake Taupo: The Early Warning Signs? A paper presented at the New Zealand Hydrological Society Symposium - Taupo. 18-21 Novermber 2003.

Vinten, A.J.A. and Smith, K.A. 1993. Nitrogen in Agricultural Soils. In: Nitrate Processes, patterns and management (Eds: Burt, T.P., Heathwaite, A.L. and Trudgill, S.T.). Wiley, Chichester.

West Coast Regional Council. 1998. Dairy Shed Effluent Database. An internal database of the West Coast Regional Council, Greymouth.

West Coast Regional Council. 2001.West Coast Groundwater Bore Inventory/Database. . An internal database of the West Coast Regional Council, Greymouth.

West Coast Regional Council. 2001. Dairy Shed Effluent Database. An internal database of the West Coast Regional Council, Greymouth.

West Coast Regional Council. 2002. Regional Plan for Discharges to Land.

West Coast Regional Council, 2003. About our region. [online]:

http://www.wcrc.govt.nz/aspcommon/layout1/.

West Coast Regional Council. 2004. Rainfall Statistics from Environmental Database.

White, E. 1983. Chemical and their importance to the Lake. NZDSIR Information series No. 158, Chapter 6, Lake Taupo, Ecology of a New Zealand Lake, p 63-72.

Wilson, S.R. 2003. The saltwater-freshwater interface, Te Horo Beach, Kapiti Coast. Unpublished MSc thesis, School of Earth Sciences, Victoria University of Wellington, $147 p$. 


\section{APPENDIX 1:SITE DETAILS}

\section{KOWHITIRANGI AREA}

\section{Kowhitirangi School bore}

\begin{tabular}{|l|l|l|}
\hline $\begin{array}{l}\text { Map/Grid } \\
\text { Reference }\end{array}$ & E2347427 N5812471 & \\
\hline Use & Domestic & \\
\hline Frequency of use & Seldom & \\
\hline $\begin{array}{l}\text { Distance of bore from } \\
\text { effluent } \\
\text { treatment/disposal } \\
\text { system }\end{array}$ & $1.1 \mathrm{~km}$ & \\
\hline Wellhead protection & Good & \\
\hline Bore depth & $12.5 \mathrm{~m}$ & \\
\hline Casing diameter & $200 \mathrm{~mm}$ \\
\hline $\begin{array}{l}\text { Environmental } \\
\text { pressures at the site }\end{array}$ & $\begin{array}{l}\text { Surrounded by dairy } \\
\text { farms }\end{array}$ \\
\hline
\end{tabular}

Michell Farm bore

\begin{tabular}{|c|c|c|}
\hline $\begin{array}{l}\text { Map/Grid } \\
\text { Reference }\end{array}$ & J33:492099 & \\
\hline Use & $\begin{array}{l}\text { Stock, domestic, dairy } \\
\text { shed }\end{array}$ & \multirow{7}{*}{ (i) } \\
\hline Frequency of use & Daily & \\
\hline $\begin{array}{l}\text { Distance of bore from } \\
\text { effluent } \\
\text { treatment/disposal } \\
\text { system }\end{array}$ & $50 \mathrm{~m}$ & \\
\hline Wellhead protection & $\begin{array}{l}\text { Poor, chemicals stored } \\
\text { close by }\end{array}$ & \\
\hline Bore depth & $10 \mathrm{~m}$ & \\
\hline Casing diameter & $200 \mathrm{~mm}$ & \\
\hline $\begin{array}{l}\text { Environmental } \\
\text { pressures at the site }\end{array}$ & $\begin{array}{l}\text { Surrounded by dairy } \\
\text { farms }\end{array}$ & \\
\hline
\end{tabular}


Robinson farm bore

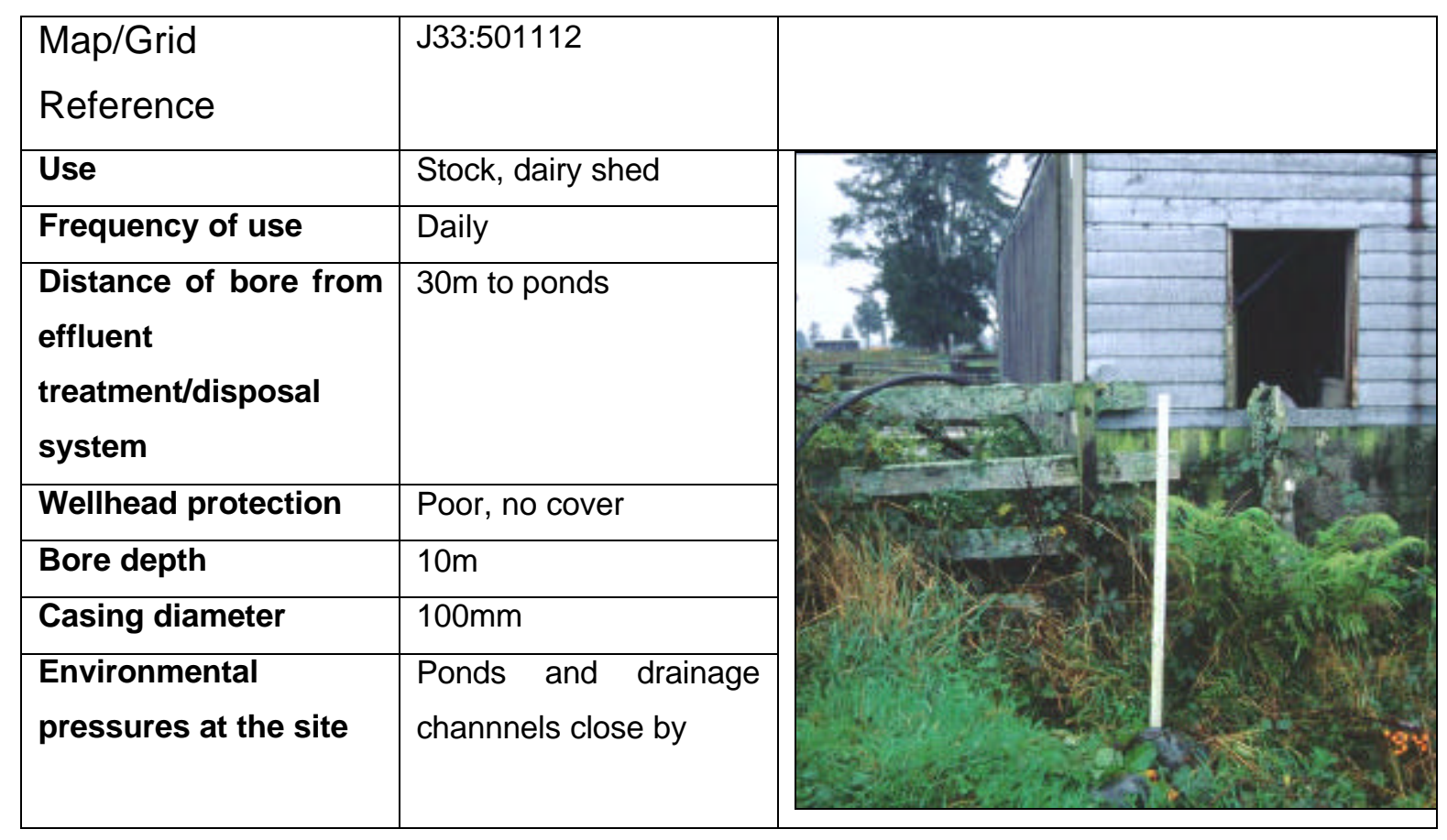


TOTARA FLAT

Begg farm bore

\begin{tabular}{|l|l|}
\hline $\begin{array}{l}\text { Map/Grid } \\
\text { Reference }\end{array}$ & E2397498 N5877655 \\
\hline Use & Stock, dairy shed \\
\hline Frequency of use & Daily \\
\hline $\begin{array}{l}\text { Distance of bore from } \\
\text { effluent } \\
\text { treatment/disposal } \\
\text { system }\end{array}$ & $80 \mathrm{~m}$ from pond \\
\hline $\begin{array}{l}\text { Wellhead protection } \\
\text { Bore depth }\end{array}$ & Light cover \\
\hline Casing diameter & $\begin{array}{l}\text { Bm } \\
\text { Environmental } \\
\text { pressures at the site } \\
\text { contaminated from } \\
\text { effluent ponds }\end{array}$ \\
\hline
\end{tabular}

Begg farm bore \#2

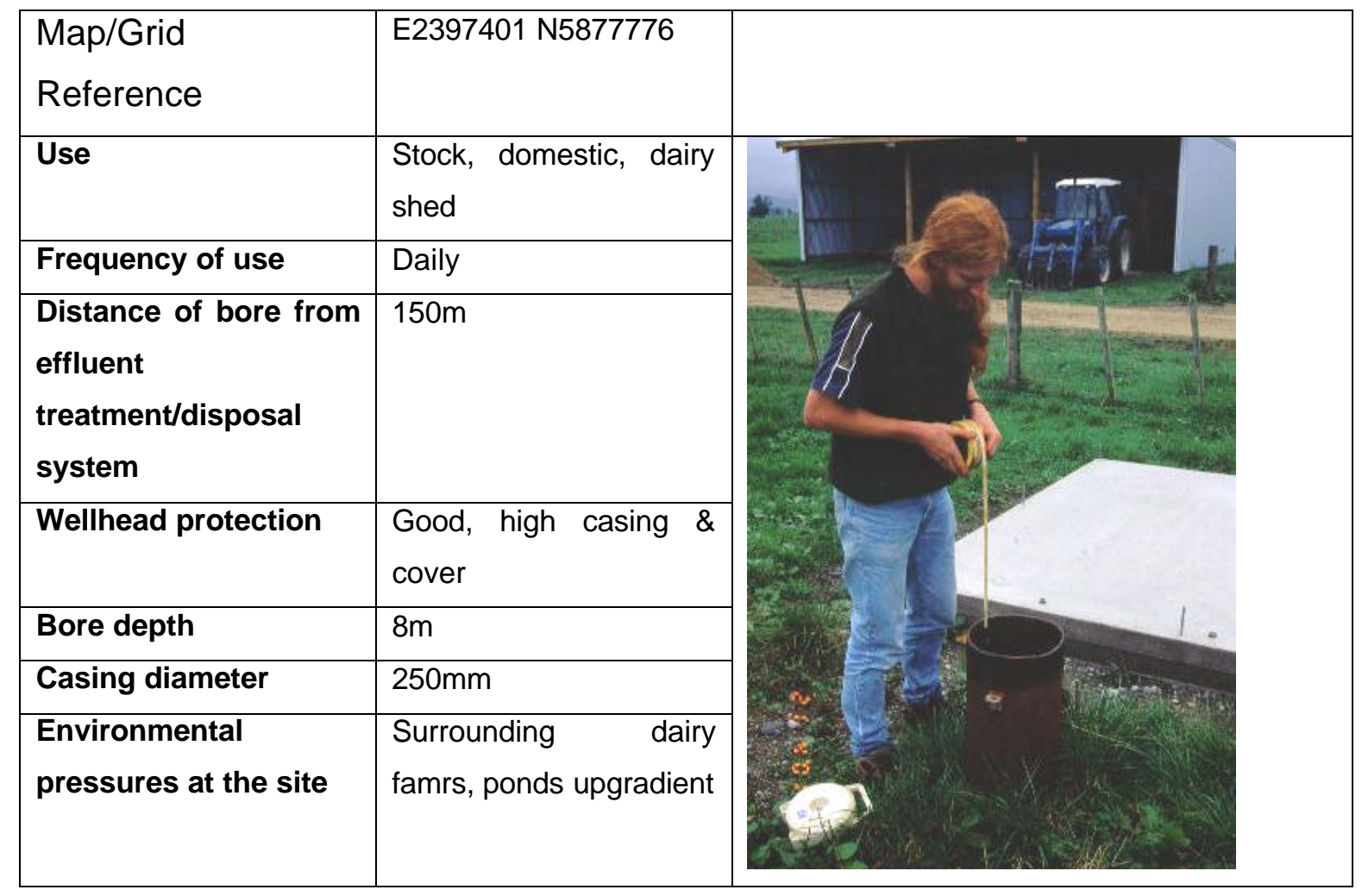


Brookshaws residence well

\begin{tabular}{|c|c|c|}
\hline $\begin{array}{l}\text { Map/Grid } \\
\text { Reference }\end{array}$ & E2395137 N5877463 & \\
\hline Use & Domestic & \\
\hline Frequency of use & Daly & \\
\hline $\begin{array}{l}\text { Distance of bore from } \\
\text { effluent } \\
\text { treatment/disposal } \\
\text { system }\end{array}$ & $1 \mathrm{~km}$ & \\
\hline Wellhead protection & Poor & \\
\hline Bore depth & $5 m$ & \\
\hline Casing diameter & $300 \mathrm{~mm}$ & \\
\hline $\begin{array}{l}\text { Environmental } \\
\text { pressures at the site }\end{array}$ & $\begin{array}{l}\text { Upgradient dairy farms, } \\
\text { grazing stock over bore }\end{array}$ & 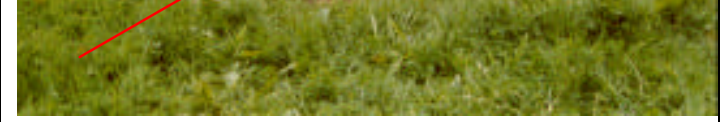 \\
\hline
\end{tabular}

\section{Burnett farm bore}

\begin{tabular}{|l|l|l|}
\hline $\begin{array}{l}\text { Map/Grid } \\
\text { Reference }\end{array}$ & E2398650 N5878860 & \\
\hline Use & Stock, dairy & \\
\hline Frequency of use & Daily & \\
\hline $\begin{array}{l}\text { Distance of bore from } \\
\text { effluent } \\
\text { treatment/disposal } \\
\text { system }\end{array}$ & $80 \mathrm{~m}$ to ponds & \\
\hline Wellhead protection & Adequate & \\
\hline Bore depth & $6 \mathrm{~m}$ & \\
\hline Casing diameter & $250 \mathrm{~mm}$ & \\
\hline $\begin{array}{l}\text { Environmental } \\
\text { pressures at the site }\end{array}$ & $\begin{array}{l}\text { Pond lining floating on } \\
\text { pond }\end{array}$ \\
\hline
\end{tabular}


Hart farm bore

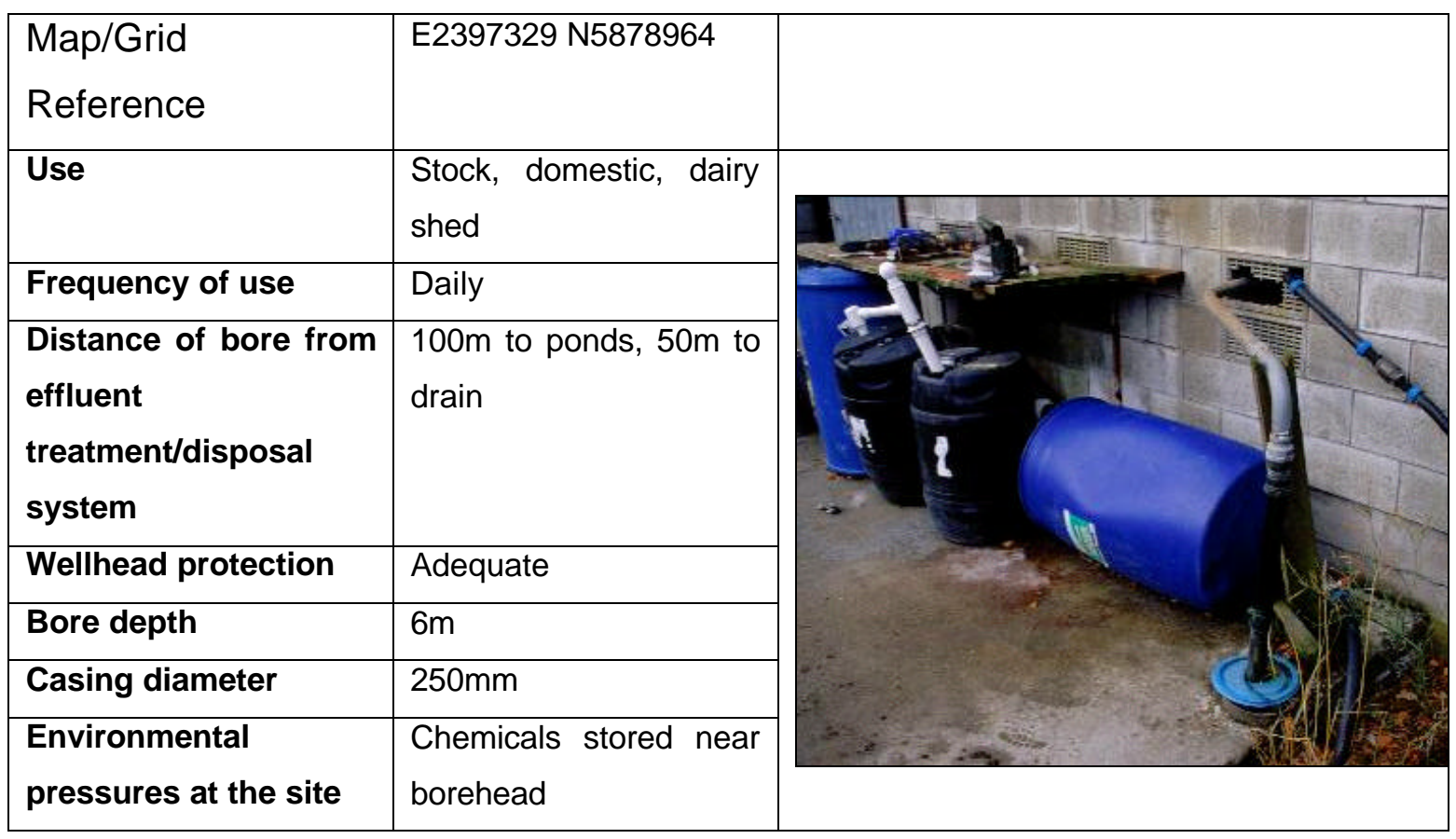

Havill Farm bore

\begin{tabular}{|l|l|l|}
\hline $\begin{array}{l}\text { Map/Grid } \\
\text { Reference }\end{array}$ & E2402350 N5880350 & \\
\hline Use & $\begin{array}{l}\text { Stock, domestic, dairy } \\
\text { shed }\end{array}$ & \\
\hline Frequency of use & Daily & \\
\hline $\begin{array}{l}\text { Distance of bore from } \\
\text { effluent } \\
\text { treatment/disposal } \\
\text { system }\end{array}$ & $120 \mathrm{~m}$ & \\
\hline Wellhead protection & Good, concrete cover & \\
\hline Bore depth & $33 \mathrm{~m}$ & \\
\hline Casing diameter & $150 \mathrm{~mm}$ & \\
\hline $\begin{array}{l}\text { Environmental } \\
\text { pressures at the site }\end{array}$ & $\begin{array}{l}\text { Land application of DSE } \\
\text { upgradient }\end{array}$ \\
\hline
\end{tabular}


Ross farm bore

\begin{tabular}{|l|l|}
\hline $\begin{array}{l}\text { Map/Grid } \\
\text { Reference }\end{array}$ & $\begin{array}{l}\text { E2396555 N5878822 } \\
\text { Use } \\
\text { domestiv }\end{array}$ \\
\hline Frequency of use & Daily shed, \\
\hline $\begin{array}{l}\text { Distance of bore from } \\
\text { effluent } \\
\text { treatment/disposal } \\
\text { system }\end{array}$ & $\begin{array}{l}4 \mathrm{~m} \mathrm{to} \mathrm{effluent} \mathrm{filled} \\
\text { drain, 100m to overfilled } \\
\text { pond }\end{array}$ \\
\hline Wellhead protection & Poor \\
\hline Bore depth & \begin{tabular}{l}
$7 \mathrm{~m}$ \\
\hline Casing diameter
\end{tabular} \\
\hline $\begin{array}{l}\text { Environmental } \\
\text { pressures at the site }\end{array}$ & $\begin{array}{l}\text { Land application of DSE } \\
\text { within 100m. Effluent } \\
\text { filled drain possibly } \\
\text { contaminating bore. }\end{array}$ \\
\hline
\end{tabular}

Wilson residence bore

\begin{tabular}{|l|l|l|}
\hline $\begin{array}{l}\text { Map/Grid } \\
\text { Reference }\end{array}$ & E2397528 N5878127 \\
\hline Use & Domestic \\
\hline Frequency of use & Daily \\
\hline $\begin{array}{l}\text { Distance of bore from } \\
\text { effluent } \\
\text { treatment/disposal } \\
\text { system }\end{array}$ & $800 \mathrm{~m}$ \\
\hline $\begin{array}{l}\text { Wellhead protection } \\
\text { Bore depth }\end{array}$ & Poor, soil falling in \\
casing
\end{tabular}




\section{AHAURA VALLEY}

\section{Bull Farm}

\begin{tabular}{|l|l|l|}
\hline $\begin{array}{l}\text { Map/Grid } \\
\text { Reference }\end{array}$ & E2392464 N5874087 \\
\hline Use & Stock, dairy shed \\
\hline Frequency of use & Daily \\
\hline $\begin{array}{l}\text { Distance of bore from } \\
\text { effluent } \\
\text { treatment/disposal } \\
\text { system }\end{array}$ & $\begin{array}{l}50 \mathrm{~m} \text { from holding pond, } \\
200 \mathrm{~m} \mathrm{from} \mathrm{closest} \\
\text { application area }\end{array}$ \\
\hline Wellhead protection & Poor - no cover \\
\hline Bore depth & $12 \mathrm{~m}$ \\
\hline Casing diameter & $150 \mathrm{~mm}$ \\
\hline $\begin{array}{l}\text { Environmental } \\
\text { pressures at the site }\end{array}$ & - & \\
\hline
\end{tabular}

\section{Bray farm bore}

\begin{tabular}{|c|c|c|}
\hline $\begin{array}{l}\text { Map/Grid } \\
\text { Reference }\end{array}$ & E2395000 N5870633 & \\
\hline Use & $\begin{array}{l}\text { Stock, dairy shed, } \\
\text { domestic }\end{array}$ & 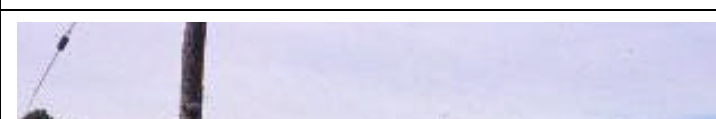 \\
\hline Frequency of use & Daily & \\
\hline $\begin{array}{l}\text { Distance of bore from } \\
\text { effluent } \\
\text { treatment/disposal } \\
\text { system }\end{array}$ & $200 \mathrm{~m}$ & \\
\hline Wellhead protection & Adequate - under drum & \\
\hline Bore depth & $48 m$ & \\
\hline Casing diameter & $250 \mathrm{~mm}$ & \\
\hline $\begin{array}{l}\text { Environmental } \\
\text { pressures at the site }\end{array}$ & $\begin{array}{l}\text { Upgradient DSE } \\
\text { application }\end{array}$ & 2 \\
\hline
\end{tabular}


Coleman farm bore

\begin{tabular}{|l|l|l|}
\hline $\begin{array}{l}\text { Map/Grid } \\
\text { Reference }\end{array}$ & $\begin{array}{l}\text { E2396399 N5870303 } \\
\text { Dairy shed, stock, } \\
\text { Use }\end{array}$ & \\
\hline Frequency of use & Daily \\
\hline $\begin{array}{l}\text { Distance of bore from } \\
\text { effluent } \\
\text { treatment/disposal } \\
\text { system }\end{array}$ & $100 \mathrm{~m}$ \\
\hline $\begin{array}{l}\text { Wellhead protection } \\
\text { high casing }\end{array}$ \\
\hline Bore depth & \begin{tabular}{l} 
Adequate - drum cover, \\
\hline Casing diameter
\end{tabular} & $\begin{array}{l}\text { Upgradient } \\
\text { grazing and DSE } \\
\text { application }\end{array}$ \\
\hline Environmental \\
pressures at the site
\end{tabular}

\section{Galligan residence bore}

\begin{tabular}{|c|c|c|}
\hline $\begin{array}{l}\text { Map/Grid } \\
\text { Reference }\end{array}$ & E2395739 N5870474 & \\
\hline Use & $\begin{array}{l}\text { Supplementary supply, } \\
\text { domestic }\end{array}$ & \multirow{7}{*}{ NO PHOTO AVAILABLE } \\
\hline Frequency of use & Monthly & \\
\hline $\begin{array}{l}\text { Distance of bore from } \\
\text { effluent } \\
\text { treatment/disposal } \\
\text { system }\end{array}$ & $\begin{array}{l}1 \mathrm{~km} \text { to nearest } \\
\text { neighbour }\end{array}$ & \\
\hline Wellhead protection & Adequate & \\
\hline Bore depth & $30 m$ & \\
\hline Casing diameter & $200 \mathrm{~mm}$ & \\
\hline $\begin{array}{l}\text { Environmental } \\
\text { pressures at the site }\end{array}$ & $\begin{array}{l}\text { Offal pit within } 5 \mathrm{~m} \text {, lots } \\
\text { of debris in bore }\end{array}$ & \\
\hline
\end{tabular}


Johnson farm bore

\begin{tabular}{|l|l|l|}
\hline $\begin{array}{l}\text { Map/Grid } \\
\text { Reference }\end{array}$ & $\begin{array}{l}\text { E2394116 N5871818 } \\
\text { Stock, dairy shed, } \\
\text { Use }\end{array}$ & Daily \\
\hline $\begin{array}{l}\text { Frequency of use } \\
\text { effluent } \\
\text { treatment/disposal } \\
\text { system }\end{array}$ & $300 \mathrm{~m}$ \\
\hline Wellhead protection & Adequate \\
\hline Bore depth & $26.2 \mathrm{~m}$ \\
\hline Casing diameter & $\begin{array}{l}\text { Several } \\
\text { Environmental } \\
\text { pressures at the site }\end{array}$ \\
\hline
\end{tabular}

\section{Mills farm bore}

\begin{tabular}{|l|l|}
\hline $\begin{array}{l}\text { Map/Grid } \\
\text { Reference }\end{array}$ & E 2392434 N5873195 \\
\hline Use & $\begin{array}{l}\text { Stock, dairy shed, } \\
\text { domestic }\end{array}$ \\
\hline Frequency of use & Daily \\
\hline $\begin{array}{l}\text { Distance of bore from } \\
\text { effluent } \\
\text { treatment/disposal } \\
\text { system }\end{array}$ & $500 \mathrm{~m}$ \\
\hline Wellhead protection & Poor - no cover \\
\hline Bore depth & $10 \mathrm{~m}$ \\
\hline Casing diameter & $\begin{array}{l}300 \mathrm{~mm} \\
\text { Engradient DSE } \\
\text { pressures at the site } \\
\text { application (note the } \\
\text { fertiliser cloud in the } \\
\text { photo). Very close to } \\
\text { road. }\end{array}$ \\
\hline
\end{tabular}


INANGAHUA VALLEY/REEFTON

Parkinson farm bore

\begin{tabular}{|c|c|c|}
\hline $\begin{array}{l}\text { Map/Grid } \\
\text { Reference }\end{array}$ & E2414111 N3900980 & \\
\hline Use & Dairy shed, stock & t. \\
\hline Frequency of use & Daily & 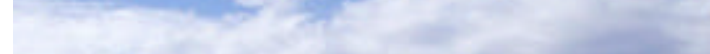 \\
\hline $\begin{array}{l}\text { Distance of bore from } \\
\text { effluent } \\
\text { treatment/disposal } \\
\text { system }\end{array}$ & $12 \mathrm{~m}$ & 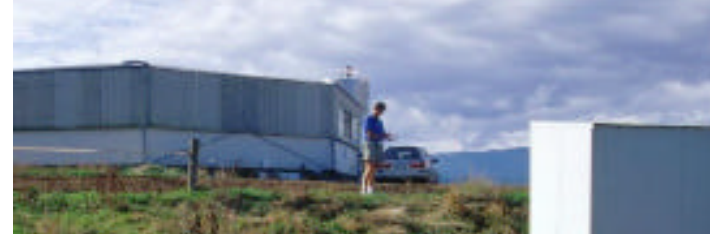 \\
\hline Wellhead protection & Good, in shed & \\
\hline Bore depth & $15 m$ & \\
\hline Casing diameter & $100 \mathrm{~mm}$ & \\
\hline $\begin{array}{l}\text { Environmental } \\
\text { pressures at the site }\end{array}$ & $\begin{array}{l}\text { Upgradient } \quad \text { DSE } \\
\text { application }\end{array}$ & W. \\
\hline
\end{tabular}

Mitchell brothers farm bore

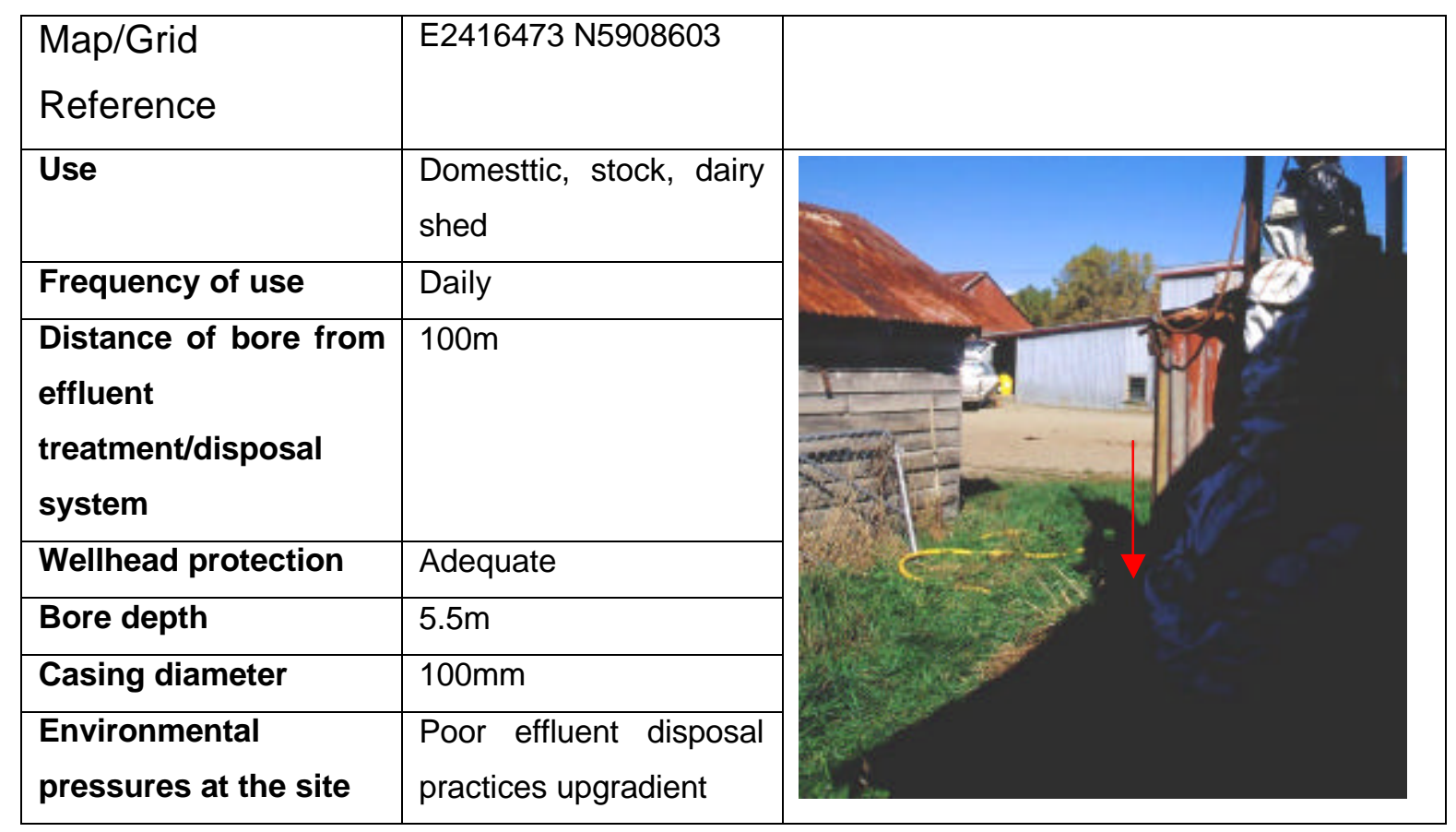




\section{APPENDIX 2: GROUNDWATER QUALITY RESULTS}

\begin{tabular}{|c|c|c|c|c|c|c|c|}
\hline Bore & Date & $\mathrm{Fe}(\mathrm{g} / \mathrm{m} 3)$ & $\mathrm{pH}$ & $\begin{array}{l}\mathrm{EC} \\
(\mu \mathrm{S} / \mathrm{cm})\end{array}$ & $\begin{array}{l}\text { Water } \\
\text { Temperature } \\
\text { (C) }\end{array}$ & DO (\%) & $\begin{array}{l}\text { Bore } \\
\text { Water } \\
\text { level }\end{array}$ \\
\hline Bulls Farm @ Ahaura & $04 / 21 / 01$ & $<0.05$ & 6.31 & 85.6 & 14.5 & 80.8 & -4.3 \\
\hline Bulls Farm @ Ahaura & $14 / 8 / 01$ & $<0.05$ & 6.19 & 156.4 & 9.3 & 70.4 & -4.3 \\
\hline Bulls Farm @ Ahaura & $15 / 10 / 01$ & $<0.05$ & 6.16 & 159.2 & 15.9 & 75.6 & -4.7 \\
\hline Brookshaws Res @ Totara Flat & $04 / 21 / 01$ & - & 6.47 & 72.4 & 14.3 & 91.3 & -3.28 \\
\hline Brookshaws Res @ Totara Flat & $06 / 12 / 01$ & $<0.05$ & 6.16 & 101.7 & 7.1 & 43.3 & -4.5 \\
\hline Brookshaws Res @ Totara Flat & $13 / 8 / 01$ & $<0.05$ & 5.89 & 140.7 & 10.4 & 44.9 & -2.8 \\
\hline Brookshaws Res @ Totara Flat & $15 / 10 / 01$ & $<0.05$ & 6.23 & 137.7 & 12.4 & 56 & -3.85 \\
\hline Ross Farm @ Totara Flat & $22 / 4 / 01$ & $<0.05$ & 5.79 & 67.2 & 14 & 33.5 & -4.5 \\
\hline Ross Farm @ Totara Flat & $12 / 06 / 01$ & $<0.05$ & 5.9 & 131 & 9.4 & 43.4 & -4 \\
\hline Ross Farm @ Totara Flat & $13 / 8 / 01$ & $<0.05$ & 5.76 & 180.4 & 12.1 & 55.4 & -4.5 \\
\hline Ross Farm @ Totara Flat & $15 / 10 / 01$ & $<0.05$ & 6.27 & 145.7 & 12.2 & 51 & -5.25 \\
\hline Begg Farm @ Totara Flat & $04 / 22 / 01$ & $<0.05$ & 6.48 & 105.2 & 15.2 & 91.6 & -3.39 \\
\hline Begg Farm @ Totara Flat & $06 / 11 / 01$ & 0.07 & 5.79 & 172.9 & 13.3 & 34.7 & -4.9 \\
\hline Begg Farm @ Totara Flat & $13 / 8 / 01$ & $<0.05$ & 5.49 & 227 & 11.1 & 41.2 & -5.1 \\
\hline Begg Farm @ Totara Flat & $14 / 10 / 01$ & 0.07 & 5.65 & 211 & 11.9 & 37.6 & -3.55 \\
\hline Wilson Res@ @ Totara Flat & $04 / 22 / 01$ & 0.46 & 6.69 & 64.8 & 13.9 & 26.5 & -3.01 \\
\hline Wilson Res @ Totara Flat & $06 / 11 / 01$ & 0.08 & 6.06 & 87.7 & 9.3 & 55.5 & -4.35 \\
\hline Wilson Res@ @ Totara Flat & $13 / 8 / 01$ & $<0.05$ & 6.1 & 173.8 & 9.8 & 46.9 & -4.1 \\
\hline Wilson Res@ @otara Flat & $14 / 10 / 01$ & $<0.05$ & 5.96 & 161.3 & 12.8 & 42 & -3.2 \\
\hline Burnett Farm @ Totara Flat & $04 / 22 / 01$ & $<0.05$ & 6.6 & 63.7 & 15.9 & 73.5 & -2.75 \\
\hline Burnett Farm @ Totara Flat & $06 / 11 / 01$ & $<0.05$ & 5.87 & 114 & 13 & 27.7 & -4.2 \\
\hline Burnett Farm @ Totara Flat & $13 / 08 / 01$ & $<0.05$ & 5.66 & 141.7 & 11.5 & 72.6 & -3.2 \\
\hline Burnett Farm @ Totara Flat & $14 / 10 / 01$ & $<0.05$ & 5.77 & 123.5 & 12.8 & 35.1 & -3.1 \\
\hline Hart Farm @ Totara Flat & $04 / 22 / 01$ & 0.05 & 6.7 & 65.8 & 15.6 & 44.2 & -4.7 \\
\hline Hart Farm @ Totara Flat & $06 / 12 / 01$ & $<0.05$ & 6.15 & 113.4 & 9.5 & 32.8 & -5.5 \\
\hline Hart Farm @ Totara Flat & $13 / 8 / 01$ & $<0.05$ & 5.98 & 167.6 & 11.7 & 35 & -5.8 \\
\hline Hart Farm @ Totara Flat & $15 / 10 / 01$ & $<0.05$ & 6.37 & 131.5 & 12.1 & 41 & -4.45 \\
\hline Havill Farm @ Ikamatua & $04 / 22 / 01$ & $<0.05$ & 6.63 & 92.8 & 13.8 & 55.5 & - \\
\hline Havill Farm @ Ikamatua & $06 / 11 / 01$ & $<0.05$ & 5.93 & 144.7 & 9.9 & 48.8 & - \\
\hline Havill Farm @ Ikamatua & $12 / 08 / 01$ & $<0.05$ & 6.06 & 250 & 12.1 & 60 & - \\
\hline Havill Farm @ Ikamatua & $14 / 10 / 01$ & $<0.05$ & 5.8 & 186.8 & 15.1 & 65.5 & 0 \\
\hline Beggs Farm \#2 @ Totara Flat & $04 / 22 / 01$ & 0.4 & 6.48 & 77.1 & 14.4 & - & -2.9 \\
\hline Beggs Farm \#2 @ Totara Flat & $06 / 11 / 01$ & 0.36 & 5.82 & 115.7 & 13.2 & 30.7 & -4.4 \\
\hline Beggs Farm \#2 @ Totara Flat & $13 / 8 / 01$ & 1.1 & 5.72 & 154.2 & 11.9 & 42.7 & -4.5 \\
\hline Beggs Farm \#2 @ Totara Flat & $14 / 10 / 01$ & 1.3 & 5.72 & 170 & 11.6 & 33.7 & -3.2 \\
\hline
\end{tabular}

Appendix 2: Groundwater quality sampling results, 2001. 


\begin{tabular}{|c|c|c|c|c|c|c|c|}
\hline Bore & Date & Time & \begin{tabular}{|l} 
Faecal \\
Coliforms \\
(cfu/100ml)
\end{tabular} & \begin{tabular}{|l} 
E.coli \\
(cfu/100ml)
\end{tabular} & $\begin{array}{l}\mathrm{NH} 4-\mathrm{N} \\
(\mathrm{g} / \mathrm{m} 3)\end{array}$ & $\begin{array}{l}\text { NO3-N } \\
\text { g/m3 }\end{array}$ & $\begin{array}{l}\text { DRP } \\
(\mathrm{g} / \mathrm{m} 3)\end{array}$ \\
\hline Bulls Farm @ Ahaura & $04 / 21 / 01$ & - & $<5$ & $<5$ & 0.015 & 2.3 & 0.008 \\
\hline Bulls Farm @ Ahaura & 14/8/01 & $11: 20$ a.m. & $<1$ & $<1$ & 0.006 & 3.3 & 0.015 \\
\hline Bulls Farm @ Ahaura & $15 / 10 / 01$ & 2:40 p.m. & 1 & 1 & 0.032 & 2.3 & 0.014 \\
\hline Brookshaws Res @ Totara Flat & $04 / 21 / 01$ & - & $<5$ & $<5$ & - & - & - \\
\hline Brookshaws Res @ Totara Flat & $06 / 12 / 01$ & $10: 45$ a.m. & $<1$ & $<1$ & 0.006 & 2.2 & 0.012 \\
\hline Brookshaws Res @ Totara Flat & $13 / 8 / 01$ & 4:15 p.m. & $<5$ & $<5$ & 0.005 & 2.4 & 0.006 \\
\hline Brookshaws Res @ Totara Flat & $15 / 10 / 01$ & 2:15 p.m. & $<1$ & $<1$ & 0.012 & 2.6 & $<0.005$ \\
\hline Ross Farm @ Totara Flat & $22 / 4 / 01$ & - & 8 & 8 & 0.18 & 0.75 & 0.044 \\
\hline Ross Farm @ Totara Flat & $12 / 06 / 01$ & $11: 00$ a.m. & 1 & 1 & 0.01 & 3 & 0.016 \\
\hline Ross Farm @ Totara Flat & $13 / 8 / 01$ & 3:50 p.m. & $<5$ & $<5$ & 0.009 & 3.1 & $<0.005$ \\
\hline Ross Farm @ Totara Flat & $15 / 10 / 01$ & 1:50 p.m. & 33 & 33 & 0.014 & 2.1 & $<0.005$ \\
\hline Begg Farm @ Totara Flat & $04 / 22 / 01$ & - & 5 & 5 & 0.12 & 1.9 & 0.012 \\
\hline Begg Farm @ Totara Flat & $06 / 11 / 01$ & 3:00 p.m. & $<1$ & $<1$ & 0.011 & 4.1 & 0.008 \\
\hline Begg Farm @ Totara Flat & $13 / 8 / 01$ & 2:20 p.m. & $<5$ & $<5$ & 0.007 & 4.7 & 0.008 \\
\hline Begg Farm @ Totara Flat & $14 / 10 / 01$ & $11: 10$ a.m. & $<1$ & $<1$ & 0.01 & 4 & 0.008 \\
\hline Wilson Res @ Totara Flat & $04 / 22 / 01$ & - & $<5$ & $<5$ & 0.017 & 0.57 & $<0.005$ \\
\hline Wilson Res@ @otara Flat & $06 / 11 / 01$ & 2:40 p.m. & $<1$ & $<1$ & 0.007 & 2 & 0.006 \\
\hline Wilson Res @ Totara Flat & $13 / 8 / 01$ & 3:00 p.m. & $<5$ & $<5$ & 0.009 & 4.2 & 0.007 \\
\hline Wilson Res @ Totara Flat & $14 / 10 / 01$ & $11: 45$ a.m. & $<1$ & $<1$ & 0.011 & 3.7 & $<0.005$ \\
\hline Burnett Farm @ Totara Flat & $04 / 22 / 01$ & - & $<5$ & $<5$ & 0.018 & 1.1 & 0.008 \\
\hline Burnett Farm @ Totara Flat & $06 / 11 / 01$ & 2:30 p.m. & $<1$ & $<1$ & 0.005 & 3.4 & 0.009 \\
\hline Burnett Farm @ Totara Flat & $13 / 08 / 01$ & 2:00 p.m. & $<5$ & $<5$ & 0.007 & 2.7 & 0.011 \\
\hline Burnett Farm @ Totara Flat & $14 / 10 / 01$ & 10:50 a.m. & $<1$ & $<1$ & 0.012 & 3.2 & 0.008 \\
\hline Hart Farm @ Totara Flat & $04 / 22 / 01$ & - & $<5$ & $<5$ & 0.018 & 0.54 & $<0.005$ \\
\hline Hart Farm @ Totara Flat & $06 / 12 / 01$ & $10: 15$ a.m. & $<1$ & $<1$ & 0.006 & 1.6 & 0.01 \\
\hline Hart Farm @ Totara Flat & $13 / 8 / 01$ & 3:25 p.m. & $<5$ & $<5$ & 0.013 & 2.7 & 0.006 \\
\hline Hart Farm @ Totara Flat & $15 / 10 / 01$ & 1:20 p.m. & $<1$ & $<1$ & 0.026 & 1.3 & $<0.005$ \\
\hline Havill Farm @ Ikamatua & $04 / 22 / 01$ & - & $<5$ & $<5$ & 0.014 & 2.2 & 0.02 \\
\hline Havill Farm@ @ Ikamatua & $06 / 11 / 01$ & 2:00 p.m. & 1 & $<1$ & 0.009 & 4 & 0.02 \\
\hline Havill Farm @ Ikamatua & $12 / 08 / 01$ & 10:00 a.m. & $<5$ & $<5$ & 0.011 & 3.1 & 0.021 \\
\hline Havill Farm @ Ikamatua & $14 / 10 / 01$ & $10: 20$ a.m. & $<1$ & $<1$ & 0.014 & 3 & 0.024 \\
\hline Beggs Farm \#2 @ Totara Flat & $04 / 22 / 01$ & - & $<5$ & $<5$ & 0.044 & 0.8 & $<0.005$ \\
\hline Beggs Farm \#2 @ Totara Flat & $06 / 11 / 01$ & 3:20 p.m. & $<1$ & $<1$ & 0.058 & 2.4 & $<0.005$ \\
\hline Beggs Farm \#2 @ Totara Flat & $13 / 8 / 01$ & 2:40 p.m. & $<5$ & $<5$ & 0.082 & 3.6 & 0.014 \\
\hline Beggs Farm \#2 @ Totara Flat & $14 / 10 / 01$ & $11: 20$ a.m. & $<1$ & $<1$ & 0.041 & 1.5 & 0.008 \\
\hline
\end{tabular}

Appendix 2: Groundwater quality sampling results, 2001. 


\begin{tabular}{|c|c|c|c|c|c|c|c|}
\hline Bore & Date & Time & \begin{tabular}{|l} 
Faecal \\
Coliforms \\
(cfu/100ml)
\end{tabular} & \begin{tabular}{|l|} 
E.coli \\
(cfu/100ml)
\end{tabular} & $\begin{array}{l}\mathrm{NH4-N} \\
(\mathrm{g} / \mathrm{m} 3)\end{array}$ & $\begin{array}{l}\text { NO3-N } \\
g / m 3\end{array}$ & $\begin{array}{l}\text { DRP } \\
(g / m 3)\end{array}$ \\
\hline Mitchell Bros Farm @ Cronadun & $19 / 04 / 01$ & - & $<5$ & $<5$ & 0.042 & 0.94 & 0.008 \\
\hline Mitchell Bros Farm @ Cronadun & $11 / 06 / 01$ & $12: 30$ p.m. & $<1$ & $<1$ & 0.006 & 1.3 & 0.015 \\
\hline Mitchell Bros Farm @ Cronadun & $12 / 08 / 01$ & 9:35 a.m. & $<5$ & $<5$ & 0.008 & 1.7 & 0.014 \\
\hline Mitchell Bros Farm @ Cronadun & $14 / 10 / 01$ & 9:00 a.m. & $<1$ & $<1$ & 0.017 & 1.2 & $<0.005$ \\
\hline Parkinson Farm @ Reefton & 04/19/01 & - & $<5$ & $<5$ & 0.019 & 2.3 & $<0.005$ \\
\hline Parkinson Farm @ Reefton & $06 / 11 / 01$ & 1:10 p.m. & $<1$ & $<1$ & $<0.005$ & 3.3 & 0.008 \\
\hline Parkinson Farm @ Reefton & $12 / 08 / 01$ & 10:40 a.m. & $<5$ & $<5$ & 0.007 & 6.8 & 0.008 \\
\hline Parkinson Farm @ Reefton & $14 / 10 / 01$ & 9:30 a.m. & $<1$ & $<1$ & 0.016 & 2.7 & $<0.005$ \\
\hline Michells Farm @ Kowhitirangi & 04/20/01 & - & $<5$ & $<5$ & 0.15 & 0.64 & 0.01 \\
\hline Michells Farm @ Kowhitirangi & $06 / 12 / 01$ & 3:45 p.m. & $<1$ & $<1$ & $<0.005$ & 0.36 & 0.018 \\
\hline Michells Farm @ Kowhitirangi & $13 / 8 / 01$ & $11: 10$ a.m. & $<5$ & $<5$ & 0.007 & 0.77 & 0.014 \\
\hline Michells Farm @ Kowhitirangi & $15 / 10 / 01$ & 10:20 a.m. & $<1$ & $<1$ & 0.02 & 0.84 & 0.011 \\
\hline Robinson Farm @ Kowhitirangi & $04 / 20 / 01$ & - & $<5$ & $<5$ & 0.031 & 1 & 0.006 \\
\hline Robinson Farm @ Kowhitirangi & $06 / 12 / 01$ & 2:10 p.m. & $<1$ & $<1$ & $<0.005$ & 0.93 & 0.012 \\
\hline Robinson Farm @ Kowhitirangi & $13 / 8 / 01$ & $11: 45$ a.m. & $<5$ & $<5$ & 0.006 & 1.3 & 0.009 \\
\hline Robinson Farm @ Kowhitirangi & $15 / 10 / 01$ & $10: 50$ a.m. & 1 & 1 & 0.015 & 1.1 & 0.008 \\
\hline Kowhitirangi School @ Kowhitirangi & $04 / 20 / 01$ & - & $<5$ & $<5$ & 0.016 & 0.58 & $<0.005$ \\
\hline Kowhitirangi School @ Kowhitirangi & $06 / 12 / 01$ & 3:25 p.m. & $<1$ & $<1$ & 0.006 & 0.64 & 0.006 \\
\hline Kowhitirangi School @ Kowhitirangi & $13 / 8 / 01$ & $10: 30$ a.m. & $<5$ & $<5$ & $<0.005$ & 0.88 & 0.009 \\
\hline Kowhitirangi School @ Kowhitirangi & $15 / 10 / 01$ & $10: 10$ a.m. & $<1$ & $<1$ & 0.036 & 0.82 & 0.026 \\
\hline Mills Farm @ Ahaura & $20 / 4 / 01$ & - & $<5$ & $<5$ & 0.019 & 3.2 & $<0.005$ \\
\hline Mills Farm @ Ahaura & $12 / 06 / 01$ & $11: 45$ a.m. & $<1$ & $<1$ & $<0.005$ & 5.4 & 0.015 \\
\hline Mills Farm @ Ahaura & $14 / 8 / 01$ & $10: 45$ a.m. & $<1$ & $<1$ & 0.006 & 8.2 & 0.006 \\
\hline Mills Farm @ Ahaura & $15 / 10 / 01$ & 4:15 p.m. & $<1$ & $<1$ & 0.021 & 5.1 & $<0.005$ \\
\hline Johnsons Farm @ Ahaura & $04 / 21 / 01$ & - & $<5$ & $<5$ & 0.014 & $<0.02$ & 0.086 \\
\hline Johnsons Farm @ Ahaura & $06 / 12 / 01$ & 12:20 p.m. & $<1$ & $<1$ & 0.01 & 0.042 & 0.016 \\
\hline Johnsons Farm @ Ahaura & $14 / 8 / 01$ & $10: 20$ a.m. & $<1$ & $<1$ & 0.009 & 0.15 & 0.032 \\
\hline Johnsons Farm @ Ahaura & $15 / 10 / 01$ & 4:00 p.m. & 41 & 41 & 0.019 & 0.19 & 0.054 \\
\hline Brays Farm @ Ahaura & $04 / 21 / 01$ & - & $<5$ & $<5$ & 0.013 & 2.3 & 0.044 \\
\hline Brays Farm @ Ahaura & $06 / 12 / 01$ & 12:45 p.m. & $<1$ & $<1$ & $<0.005$ & 2.1 & 0.039 \\
\hline Brays Farm @ Ahaura & $14 / 8 / 01$ & 9:45 a.m. & $<1$ & $<1$ & 0.006 & 2.3 & 0.043 \\
\hline Brays Farm @ Ahaura & $15 / 10 / 01$ & 3:40 p.m. & $<1$ & $<1$ & 0.008 & 2.3 & 0.052 \\
\hline Galligans Residence @ Ahaura & $04 / 21 / 01$ & - & 5 & 5 & 0.017 & 2 & 0.018 \\
\hline Galligans Residence @ Ahaura & $06 / 12 / 01$ & 1:10 p.m. & $<1$ & $<1$ & 0.024 & 2.2 & 0.021 \\
\hline Galligans Residence @ Ahaura & $14 / 8 / 01$ & 9:10 a.m. & $<1$ & $<1$ & 0.008 & 2.8 & 0.026 \\
\hline Galligans Residence @ Ahaura & $15 / 10 / 01$ & 3:20 p.m. & $<1$ & $<1$ & 0.014 & 2.7 & 0.016 \\
\hline Colemans Farm @ Ahaura & $21 / 04 / 01$ & - & $<5$ & $<5$ & 0.013 & 1 & 0.022 \\
\hline Colemans Farm @ Ahaura & $06 / 12 / 01$ & 1:30 p.m. & $<1$ & $<1$ & $<0.005$ & 1.4 & 0.029 \\
\hline Colemans Farm @ Ahaura & $14 / 8 / 01$ & 8:45 a.m. & $<1$ & $<1$ & 0.008 & 1.5 & 0.033 \\
\hline Colemans Farm @ Ahaura & $15 / 10 / 01$ & 3:00 p.m. & $<1$ & $<1$ & 0.014 & 1.4 & 0.023 \\
\hline
\end{tabular}

Appendix 2: Groundwater quality sampling results, 2001. 


\begin{tabular}{|c|c|c|c|c|c|c|c|}
\hline Bore & Date & $\mathrm{Fe}(\mathrm{g} / \mathrm{m} 3)$ & $\mathrm{pH}$ & $\begin{array}{l}\text { E EC } \\
(\mu S / \mathrm{cm})\end{array}$ & $\begin{array}{l}\text { Water } \\
\text { Temperature } \\
\text { (C) }\end{array}$ & DO (\%) & $\begin{array}{l}\text { Bore } \\
\text { Water } \\
\text { level }\end{array}$ \\
\hline Mitchell Bros Farm @ Cronadun & $19 / 04 / 01$ & - & 7.22 & 58.5 & 15.7 & 53.8 & -2.94 \\
\hline Mitchell Bros Farm @ Cronadun & $11 / 06 / 01$ & $<0.05$ & 5.89 & 83.1 & 14 & 35.8 & -4.5 \\
\hline Mitchell Bros Farm @ Cronadun & $12 / 08 / 01$ & $<0.05$ & 5.8 & 191.5 & 11.7 & 45 & -2.7 \\
\hline Mitchell Bros Farm @ Cronadun & $14 / 10 / 01$ & $<0.05$ & 5.7 & 134.1 & 11.6 & 42 & -3 \\
\hline Parkinson Farm @ Reefton & 04/19/01 & - & 7.34 & 67.9 & 15.8 & 75.6 & -9.6 \\
\hline Parkinson Farm @ Reefton & $06 / 11 / 01$ & $<0.05$ & 5.4 & 46 & 12 & 43.9 & - \\
\hline Parkinson Farm @ Reefton & $12 / 08 / 01$ & $<0.05$ & 5.95 & 273 & 8.1 & 67.5 & - \\
\hline Parkinson Farm @ Reefton & $14 / 10 / 01$ & 0.07 & 5.5 & 121.5 & 12.9 & 82 & - \\
\hline Michells Farm @ Kowhitirangi & $04 / 20 / 01$ & $<0.05$ & 5.62 & 80.3 & 14.1 & 53.6 & -3.4 \\
\hline Michells Farm @ Kowhitirangi & $06 / 12 / 01$ & $<0.05$ & 5.87 & 92.1 & 12.9 & 50.3 & -3.2 \\
\hline Michells Farm @ Kowhitirangi & $13 / 8 / 01$ & $<0.05$ & 5.79 & 134.1 & 12.3 & 40.5 & -3.15 \\
\hline Michells Farm @ Kowhitirangi & $15 / 10 / 01$ & $<0.05$ & 5.81 & 136 & 12.9 & 43.3 & -3.3 \\
\hline Robinson Farm @ Kowhitirangi & 04/20/01 & $<0.05$ & 5.14 & 84.4 & 13.2 & 54.7 & -2.08 \\
\hline Robinson Farm @ Kowhitirangi & $06 / 12 / 01$ & 0.18 & 5.89 & 97.6 & 9.9 & 50.1 & -2.1 \\
\hline Robinson Farm @ Kowhitirangi & $13 / 8 / 01$ & $<0.05$ & 5.87 & 141.4 & 11.5 & 33.7 & -2 \\
\hline Robinson Farm @ Kowhitirangi & $15 / 10 / 01$ & $<0.05$ & 176 & 140 & 12.6 & 43.3 & -2 \\
\hline Kowhitirangi School @ Kowhitirangi & $04 / 20 / 01$ & 0.11 & 6.97 & 88.5 & 12.3 & 66.8 & -3.1 \\
\hline Kowhitirangi School @ Kowhitirangi & $06 / 12 / 01$ & 0.72 & 6.39 & 104.9 & 12.1 & 71.5 & - \\
\hline Kowhitirangi School @ Kowhitirangi & $13 / 8 / 01$ & 0.15 & 6.56 & 158.5 & 11.5 & 61.2 & - \\
\hline Kowhitirangi School @ Kowhitirangi & $15 / 10 / 01$ & 0.53 & 6.59 & 158.7 & 11.6 & 56.9 & - \\
\hline Mills Farm @ Ahaura & 20/4/01 & $<0.05$ & 6.97 & 77.2 & 13.8 & - & -6.2 \\
\hline Mills Farm @ Ahaura & $12 / 06 / 01$ & $<0.05$ & 5.56 & 152.3 & 12.9 & 80.2 & -7.9 \\
\hline Mills Farm @ Ahaura & $14 / 8 / 01$ & $<0.05$ & 5.89 & 252 & 12.3 & 67.3 & -4.9 \\
\hline Mills Farm @ Ahaura & $15 / 10 / 01$ & 0.3 & 5.44 & 199.1 & 12.1 & 54 & -5.4 \\
\hline Johnsons Farm @ Ahaura & $04 / 21 / 01$ & 2.3 & 6.79 & 155.6 & 12.7 & 24.7 & -12.87 \\
\hline Johnsons Farm @ Ahaura & $06 / 12 / 01$ & 8.1 & 6.65 & 185.5 & 10.2 & 6.4 & -6.9 \\
\hline Johnsons Farm @ Ahaura & $14 / 8 / 01$ & 1.5 & 7.88 & 289 & 6.5 & 41.7 & -4.1 \\
\hline Johnsons Farm @ Ahaura & $15 / 10 / 01$ & 1.6 & 6.55 & 260 & 17.5 & 57.7 & -4.6 \\
\hline Brays Farm @ Ahaura & $04 / 21 / 01$ & 0.14 & 6.73 & 128.3 & 13 & 63.3 & -20.5 \\
\hline Brays Farm @ Ahaura & $06 / 12 / 01$ & $<0.05$ & 6.14 & 143 & 12.9 & 48.9 & -16.1 \\
\hline Brays Farm @ Ahaura & $14 / 8 / 01$ & 1.4 & 6.53 & 209 & 13 & 36.6 & -16.15 \\
\hline Brays Farm @ Ahaura & $15 / 10 / 01$ & 0.19 & 5.92 & 210 & 13 & 42.1 & -21 \\
\hline Galligans Residence @ Ahaura & $04 / 21 / 01$ & $<0.05$ & 6.7 & 95.4 & 13.1 & 51.2 & -15.8 \\
\hline Galligans Residence @ Ahaura & $06 / 12 / 01$ & 0.12 & 5.85 & 111.9 & 6.9 & 43 & -12.6 \\
\hline Galligans Residence @ Ahaura & $14 / 8 / 01$ & 0.08 & 5.64 & 170 & 11.2 & 42.1 & -12.3 \\
\hline Galligans Residence @ Ahaura & $15 / 10 / 01$ & 0.14 & 5.01 & 172.5 & 13.3 & 36.1 & -16 \\
\hline Colemans Farm @ Ahaura & $21 / 04 / 01$ & $<0.05$ & 6.27 & 71.5 & 12.7 & 37.8 & -17.5 \\
\hline Colemans Farm @ Ahaura & $06 / 12 / 01$ & 0.08 & 5.65 & 98.9 & 12 & 38.7 & -13.2 \\
\hline Colemans Farm @ Ahaura & $14 / 8 / 01$ & 0.19 & 5.56 & 127.7 & 11.4 & 34.5 & -12 \\
\hline Colemans Farm @ Ahaura & 15/10/01 & $<0.05$ & 5.81 & 123.1 & 12.7 & 37.7 & -15.4 \\
\hline
\end{tabular}

Appendix 2: Groundwater quality sampling results, 2001. 


\section{APPENDIX 3: NGMP RESULTS}

\begin{tabular}{|c|c|c|c|c|c|c|c|c|c|c|}
\hline Bore & $\begin{array}{l}\text { SAMPLE_S } \\
\text { ATE }\end{array}$ & $\overline{\text { RT_D }}$ & $\begin{array}{l}\text { SAMPLE_NU } \\
\text { MBER }\end{array}$ & $\mathrm{pH}$ & $\begin{array}{l}\text { alkalinity } \\
\text { as } \mathrm{HCO} \text { - } \\
\text { total ( } \mathrm{mg} / \mathrm{L} \\
\text { ) }\end{array}$ & $\begin{array}{l}\mathrm{Br} \\
\text { total } \\
\mathrm{mg} / \mathrm{L})\end{array}$ & $\left(\begin{array}{l}\mathrm{Ca} \\
\mathrm{mg} / \mathrm{L})\end{array}\right.$ & $\left(\begin{array}{ll}\mathrm{Cl} & ( \\
\mathrm{mg} / \mathrm{L}\end{array}\right)$ & $\begin{array}{l}\text { Field } \\
\mathrm{pH}\end{array}$ & \begin{tabular}{|l} 
Field DO \\
$\mathrm{mg} / \mathrm{L})$
\end{tabular} \\
\hline WCRC-ANDERSON & 15-Sep-98 & $13: 30$ & 4158 & 6.5 & 33 & & 8.6 & 2 & & \\
\hline WCRC-ANDERSON & 15-Sep-98 & $13: 30$ & 6680 & & & & & & 5.9 & \\
\hline WCRC-ANDERSON & 07-Dec-98 & $17: 00$ & 4341 & 6.4 & 33 & & 8.7 & 2 & & \\
\hline WCRC-ANDERSON & 07-Dec-98 & $17: 00$ & 6679 & & & & & & 5.57 & 5.13 \\
\hline WCRC-ANDERSON & 01-Mar-99 & $15: 10$ & 4523 & 6.3 & 31 & & 8 & 2.1 & & \\
\hline WCRC-ANDERSON & 01-Mar-99 & $15: 10$ & 6681 & & & & & & & 10.2 \\
\hline WCRC-ANDERSON & 16-Jun-99 & $12: 00$ & 7263 & 6.5 & 32 & $<0.02$ & 8.4 & 3 & & \\
\hline WCRC-ANDERSON & 16-Jun-99 & 12:00 & 7781 & & & & & & & 5.21 \\
\hline WCRC-ANDERSON & 08-Sep-99 & $10: 15$ & 7335 & 6.2 & 32 & 0.04 & 8 & 2.4 & & 8.11 \\
\hline WCRC-ANDERSON & 09-Dec-99 & 12:15 & 7950 & 6.1 & 33 & $<0.03$ & 8.6 & 2.5 & 5.78 & 4.1 \\
\hline WCRC-ANDERSON & 07-Mar-00 & $13: 00$ & 8034 & 6.1 & 32 & $<0.03$ & & 2.5 & 5.84 & 2.8 \\
\hline WCRC-ANDERSON & 07-Jun-00 & $11: 00$ & 8298 & 6.1 & 33 & $<0.03$ & 8.4 & 2.4 & 6.46 & 8 \\
\hline WCRC-ANDERSON & 18-Sep-00 & 15:00 & 8172 & 5.9 & 33 & $<0.03$ & & 2.4 & 5.52 & 3.92 \\
\hline WCRC-ANDERSON & $15-$ Dec-00 & $10: 30$ & 8423 & 6 & 33 & $<0.03$ & 8.1 & 1.7 & 5.52 & 5.85 \\
\hline WCRC-ANDERSON & 13-Mar-01 & $13: 00$ & 8515 & 5.9 & 32 & $<0.03$ & 7.9 & 2.4 & 5.56 & \\
\hline WCRC-ANDERSON & 11-Jun-01 & $10: 09$ & 9340 & 6 & 33 & $<0.03$ & 8.3 & 2.6 & & 7.2 \\
\hline WCRC-ANDERSON & 11-Sep-01 & 11:00 & 9492 & 6.1 & 34 & 0.07 & 8.4 & 2.8 & 6.26 & 5.17 \\
\hline WCRC-BERTACCO & 14-Sep-98 & $16: 30$ & 4154 & 6.7 & 34 & & 8.9 & 4.7 & & \\
\hline WCRC-BERTACCO & 14-Sep-98 & $16: 30$ & 6682 & & & & & & & \\
\hline WCRC-BERTACCO & 08-Dec-98 & $17: 00$ & 4337 & 6.5 & 36 & & 9.2 & 5.03 & & \\
\hline WCRC-BERTACCO & 02-Mar-99 & $13: 05$ & 4520 & 6.9 & 39 & & 9.4 & 5.8 & & \\
\hline WCRC-BERTACCO & 02-Mar-99 & 13:05 & 6683 & & & & & & & \\
\hline WCRC-BERTACCO & 17-Jun-99 & $10: 45$ & 7259 & 6.2 & 34 & 0.06 & 8.7 & 5.2 & & \\
\hline WCRC-BERTACCO & 17-Jun-99 & $10: 45$ & 7776 & & & & & & & 10.5 \\
\hline WCRC-BERTACCO & 08-Sep-99 & $15: 00$ & 7331 & 6.4 & 33 & 0.03 & 8.1 & 4.9 & 5.69 & 8.62 \\
\hline WCRC-BERTACCO & 10-Dec-99 & $15: 00$ & 7958 & 7.5 & 35 & 0.07 & 8.6 & 5.3 & & \\
\hline WCRC-BERTACCO & 08-Mar-00 & $11: 45$ & 8039 & & & 0.05 & & 5.8 & 6.23 & 9.3 \\
\hline WCRC-BERTACCO & 06-Jun-00 & $13: 00$ & 8293 & 6.3 & 33 & 0.04 & 8.4 & 5.3 & 6.52 & 7.9 \\
\hline WCRC-BERTACCO & 19-Sep-00 & $10: 00$ & 8168 & 6.3 & 33 & 0.07 & 8.1 & 5.5 & 6.07 & 9.74 \\
\hline WCRC-BERTACCO & 15-Dec-00 & $7: 30$ & 8419 & 6.3 & 37 & 0.04 & 9.1 & 5.1 & 6.21 & 8.49 \\
\hline WCRC-BERTACCO & 14-Mar-01 & $10: 30$ & 8511 & 6.2 & 35 & 0.06 & 9 & 7.4 & & \\
\hline WCRC-BERTACCO & 07-Jun-01 & $10: 51$ & 9336 & 6.2 & 34 & 0.06 & 8.6 & 6.1 & 6.34 & 11.4 \\
\hline WCRC-BERTACCO & 12-Sep-01 & $11: 15$ & 9488 & 6.3 & 35 & 0.15 & 8.9 & 6 & 6.86 & 9.41 \\
\hline WCRC-BERTACCO & 17-Dec-01 & 13:15 & 9587 & 8 & 32 & $<0.03$ & 8.1 & 6.1 & 7.1 & 9.29 \\
\hline WCRC-BERTACCO & 13-Mar-02 & $11: 00$ & 9699 & 6 & 34 & $<0.10$ & 8.8 & 6.7 & 6.14 & 4.1 \\
\hline WCRC-BERTACCO & 26-Jun-02 & $11: 20$ & 9820 & 6.1 & 29 & $<0.10$ & 8.1 & 6.4 & 6.05 & 8.96 \\
\hline WCRC-BERTACCO & 18-Sep-02 & $12: 40$ & 10271 & 6 & 30 & $<0.10$ & 8.8 & 6.9 & 5.64 & \\
\hline WCRC-BERTACCO & 06-Dec-02 & $9: 35$ & 10349 & 6 & 29 & $<0.10$ & 9 & 7.3 & 5.51 & 6.5 \\
\hline WCRC-BERTACCO & 03-Mar-03 & $10: 30$ & 21401 & 6.2 & 30 & $<0.10$ & 9.8 & 7.5 & 6.57 & 4.4 \\
\hline WCRC-BERTACCO & 11-Jun-03 & $10: 15$ & 21543 & 5.9 & 29 & $<0.10$ & 9.6 & 7.2 & 5.97 & \\
\hline
\end{tabular}

Appendix 3: NGMP results, 1998 - 2003. Source: GNS, 2004. 


\begin{tabular}{|c|c|c|c|c|c|c|c|c|}
\hline Bore & $\begin{array}{l}\text { SAMPLE_ST } \\
\text { ART_DATE }\end{array}$ & $\begin{array}{ll}\text { Field } & - \\
\text { static } & \\
\text { water } & \\
\text { level } & ( \\
\text { m ) } & \end{array}$ & $\begin{array}{l}\text { Field } \\
\text { temperature } \\
\text { deg_C ) }\end{array}$ & $\left(\begin{array}{ll}\mathrm{EC} \\
\mathrm{uS} / \mathrm{cm} \\
)\end{array}\right.$ & F ( mg/L & $\begin{array}{l}\mathrm{Fe} \\
\mathrm{mg} / \mathrm{L})\end{array}$ & $\left(\begin{array}{l}M g \\
m g / L ~)\end{array}\right.$ & $\left(\begin{array}{l}M n \\
m g / L)\end{array}\right.$ \\
\hline WCRC-ANDERSON & $15-\operatorname{Sep}-98$ & & & & & $<0.01$ & 1.2 & $<0.01$ \\
\hline WCRC-ANDERSON & 15-Sep-98 & 8.02 & 13.2 & 80 & & & & \\
\hline WCRC-ANDERSON & 07-Dec-98 & & & & & $<0.01$ & 1.1 & $<0.01$ \\
\hline WCRC-ANDERSON & 07-Dec-98 & 8.25 & 12.68 & 61 & & & & \\
\hline WCRC-ANDERSON & 01-Mar-99 & & & & & 0.03 & 1.1 & $<0.02$ \\
\hline WCRC-ANDERSON & 01-Mar-99 & 8.8 & 13.3 & 62 & & & & \\
\hline WCRC-ANDERSON & 16-Jun-99 & & & & $<0.05$ & $<0.02$ & 1.1 & $<0.005$ \\
\hline WCRC-ANDERSON & 16-Jun-99 & 7.9 & 12.85 & 64 & & & & \\
\hline WCRC-ANDERSON & 08-Sep-99 & 8.98 & 13.15 & 66 & $<0.05$ & $<0.02$ & 1.2 & $<0.005$ \\
\hline WCRC-ANDERSON & 09-Dec-99 & 6.975 & 12.99 & 50 & 0.05 & $<0.02$ & 1.2 & $<0.005$ \\
\hline WCRC-ANDERSON & 07-Mar-00 & 8.198 & 12.91 & & $<0.05$ & & & \\
\hline WCRC-ANDERSON & 07-Jun-00 & 6.68 & 13.07 & 60 & 0.09 & 0.03 & 1.2 & 0.01 \\
\hline WCRC-ANDERSON & 18-Sep-00 & 7.95 & 13.09 & 61 & 0.05 & $<0.02$ & 1.2 & $<0.005$ \\
\hline WCRC-ANDERSON & 15-Dec-00 & 8.78 & 13.43 & & $<0.05$ & 0.023 & 1.1 & $<0.005$ \\
\hline WCRC-ANDERSON & 13-Mar-01 & 9.05 & 13.2 & 62 & 0.07 & $<0.02$ & 1.1 & $<0.005$ \\
\hline WCRC-ANDERSON & 11-Jun-01 & 8.35 & 12.4 & 58 & 0.05 & $<0.02$ & 1.1 & $<0.005$ \\
\hline WCRC-ANDERSON & 11-Sep-01 & 8.49 & 14 & 78 & $<0.05$ & $<0.02$ & 1.3 & $<0.005$ \\
\hline WCRC-BERTACCO & 14-Sep-98 & & & & & 0.03 & 2.2 & $<0.01$ \\
\hline WCRC-BERTACCO & 14-Sep-98 & & & & & & & \\
\hline WCRC-BERTACCO & 08-Dec-98 & & & & & 0.06 & 2.3 & 0.02 \\
\hline WCRC-BERTACCO & 02-Mar-99 & & & & & $<0.02$ & 2.4 & $<0.02$ \\
\hline WCRC-BERTACCO & 02-Mar-99 & & & & & & & \\
\hline WCRC-BERTACCO & 17-Jun-99 & & & & $<0.05$ & $<0.02$ & 2.2 & 0.005 \\
\hline WCRC-BERTACCO & 17-Jun-99 & 21.6 & 11.21 & 83 & & & & \\
\hline WCRC-BERTACCO & 08-Sep-99 & $>15.00$ & 12.65 & 79 & $<0.05$ & $<0.02$ & 2.1 & $<0.005$ \\
\hline WCRC-BERTACCO & 10-Dec-99 & $>15$ & & & 0.05 & $<0.02$ & 2.2 & $<0.005$ \\
\hline WCRC-BERTACCO & 08-Mar-00 & $>15$ & 14.14 & & 0.05 & & & \\
\hline WCRC-BERTACCO & 06-Jun-00 & $>15$ & 12.9 & & 0.06 & 0.03 & 2.2 & $<0.005$ \\
\hline WCRC-BERTACCO & 19-Sep-00 & $>16$ & 13.2 & 78 & $<0.05$ & 0.04 & 2.2 & 0.006 \\
\hline WCRC-BERTACCO & 15-Dec-00 & $>15$ & 16.53 & & $<0.05$ & 0.046 & 2.4 & 0.008 \\
\hline WCRC-BERTACCO & 14-Mar-01 & $>15$ & 14.01 & 90 & $<0.05$ & 0.02 & 2.4 & $<0.005$ \\
\hline WCRC-BERTACCO & 07-Jun-01 & $>15$ & 11.73 & 65 & 0.05 & 0.04 & 2.1 & 0.006 \\
\hline WCRC-BERTACCO & 12-Sep-01 & $>15$ & 13.4 & 104 & 0.05 & 0.021 & 2.4 & $<0.005$ \\
\hline WCRC-BERTACCO & 17-Dec-01 & $>15$ & 15.6 & 101 & 0.03 & 0.023 & 2 & 0.005 \\
\hline WCRC-BERTACCO & 13-Mar-02 & & 13.8 & 115 & 0.04 & $<0.02$ & 2.3 & $<0.005$ \\
\hline WCRC-BERTACCO & 26-Jun-02 & 14.515 & 13.08 & 72 & 0.04 & 0.033 & 2.3 & 0.006 \\
\hline WCRC-BERTACCO & 18-Sep-02 & $>15$ & 13 & 104 & 0.04 & 0.025 & 2.2 & $<0.005$ \\
\hline WCRC-BERTACCO & 06-Dec-02 & $>15$ & 13.4 & 110 & 0.06 & 0.013 & 2.2 & $<0.005$ \\
\hline WCRC-BERTACCO & 03-Mar-03 & $>15$ & 13.5 & 176 & 0.03 & $<0.02$ & 2.6 & $<0.005$ \\
\hline WCRC-BERTACCO & 11-Jun-03 & $>15$ & 11.8 & 112 & 0.05 & $<0.02$ & 2.6 & 0.019 \\
\hline
\end{tabular}

Appendix 3: NGMP results, 1998 - 2003. Source: GNS, 2004. 


\begin{tabular}{|c|c|c|c|c|c|c|c|c|c|}
\hline Bore & $\begin{array}{l}\text { SAMPLE_ST } \\
\text { ART_DATE }\end{array}$ & $\begin{array}{l}\text { nitrogen } \\
\text { (ammonium) } \\
\text { as } \quad \mathrm{N} \quad- \\
\text { soluble } \quad( \\
\mathrm{mg} / \mathrm{L})\end{array}$ & $\begin{array}{l}\text { nitrogen } \\
\text { (nitrate) as } \mathrm{N} \text { - } \\
\text { total ( } \mathrm{mg} / \mathrm{L})\end{array}$ & $\begin{array}{l}\text { DRP } \\
(\mathrm{mg} / \mathrm{l})\end{array}$ & $\begin{array}{l}\text { potassium (all } \\
\text { forms) as } \mathrm{K} \text { - } \\
\text { total }(\mathrm{mg} / \mathrm{L})\end{array}$ & $\begin{array}{l}\mathrm{SiO2} \\
\mathrm{mg} / \mathrm{L})\end{array}$ & $\left(\begin{array}{ll}\mathrm{Na} \\
\mathrm{mg} / \mathrm{L})\end{array}\right.$ & $\left(\begin{array}{l}\mathrm{SO} 4 \\
\mathrm{mg} / \mathrm{L})\end{array}\right.$ & $\left(\begin{array}{l}\text { EC } \\
\text { uS/cm) }\end{array}\right.$ \\
\hline WCRC-ANDERSON & 15-Sep-98 & $<0.01$ & 1.25 & $<0.1$ & 2.8 & 13.6 & 3.3 & 2.7 & 70 \\
\hline WCRC-ANDERSON & 15-Sep-98 & & & & & & & & \\
\hline WCRC-ANDERSON & 07-Dec-98 & $<0.01$ & 0.75 & & 2.8 & 13.3 & 3.4 & 3 & 70 \\
\hline WCRC-ANDERSON & 07-Dec-98 & & & & & & & & \\
\hline WCRC-ANDERSON & 01-Mar-99 & $<0.01$ & 0.8 & & 2.9 & 13.6 & 3.3 & 2.9 & 40 \\
\hline WCRC-ANDERSON & 01-Mar-99 & & & & & & & & \\
\hline WCRC-ANDERSON & 16-Jun-99 & $<0.01$ & 1 & $<0.03$ & 2.9 & 13.9 & 3.4 & 5 & 100 \\
\hline WCRC-ANDERSON & 16-Jun-99 & & & & & & & & \\
\hline WCRC-ANDERSON & 08-Sep-99 & $<0.01$ & 0.88 & 0.04 & 3.2 & 12.7 & 3.2 & 3.2 & 70 \\
\hline WCRC-ANDERSON & 09-Dec-99 & $<0.01$ & 0.97 & $<0.04$ & 3 & 12.8 & 3.5 & 3.5 & 90 \\
\hline WCRC-ANDERSON & 07-Mar-00 & $<0.01$ & 0.9 & $<0.04$ & 2.8 & & 3 & 3.3 & 80 \\
\hline WCRC-ANDERSON & 07-Jun-00 & 0.01 & 0.94 & $<0.04$ & 2.9 & 12.9 & 3.6 & 3.2 & 80 \\
\hline WCRC-ANDERSON & 18-Sep-00 & 0.02 & 1 & $<0.04$ & 3 & & & 3.5 & 80 \\
\hline WCRC-ANDERSON & 15-Dec-00 & 0.01 & 0.79 & $<0.04$ & 2.9 & 12.9 & 3 & 2.6 & 80 \\
\hline WCRC-ANDERSON & 13-Mar-01 & $<0.01$ & 0.85 & $<0.04$ & 2.9 & 12.5 & 3.1 & 3.2 & 80 \\
\hline WCRC-ANDERSON & 11-Jun-01 & 0.01 & 0.87 & $<0.04$ & 2.8 & 13.2 & 3.3 & & 80 \\
\hline WCRC-ANDERSON & 11-Sep-01 & $<0.01$ & 0.93 & $<0.04$ & 2.7 & 13.1 & 3.6 & 3.8 & 80 \\
\hline WCRC-BERTACCO & 14-Sep-98 & $<0.01$ & 1.25 & $<0.1$ & 0.63 & 20.6 & 7.7 & 7.4 & 100 \\
\hline WCRC-BERTACCO & 14-Sep-98 & & & & & & & & 120 \\
\hline WCRC-BERTACCO & 08-Dec-98 & $<0.01$ & 1.6 & & 0.66 & 22 & 8.3 & 6.8 & 110 \\
\hline WCRC-BERTACCO & 02-Mar-99 & $<0.01$ & 1.5 & & 0.74 & 22 & 8.4 & 6.1 & 80 \\
\hline WCRC-BERTACCO & 02-Mar-99 & & & & & & & & 92 \\
\hline WCRC-BERTACCO & 17-Jun-99 & $<0.01$ & 1.5 & $<0.03$ & 0.74 & 22 & 7.8 & 7 & 110 \\
\hline WCRC-BERTACCO & 17-Jun-99 & & & & & & & & \\
\hline WCRC-BERTACCO & 08-Sep-99 & $<0.01$ & 1.4 & 0.06 & 0.79 & 19.5 & 7.5 & 7.1 & 100 \\
\hline WCRC-BERTACCO & 10-Dec-99 & $<0.01$ & 1.7 & 0.05 & 0.77 & 19.8 & 7.8 & 6.9 & 110 \\
\hline WCRC-BERTACCO & 08-Mar-00 & $<0.01$ & 1.9 & $<0.04$ & 0.68 & & 7.8 & 6.5 & 120 \\
\hline WCRC-BERTACCO & 06-Jun-00 & $<0.01$ & 1.8 & $<0.04$ & 0.67 & 19.2 & 7.3 & 6.4 & 100 \\
\hline WCRC-BERTACCO & 19-Sep-00 & $<0.01$ & 1.9 & $<0.04$ & 0.68 & 17.5 & 7.5 & 6.1 & 100 \\
\hline WCRC-BERTACCO & 15-Dec-00 & $<0.01$ & 1.8 & $<0.04$ & 0.72 & 18.7 & 7.8 & 5.2 & 110 \\
\hline WCRC-BERTACCO & 14-Mar-01 & 5.4 & 2.1 & 0.05 & 1.6 & 18.8 & 8.3 & 6 & 120 \\
\hline WCRC-BERTACCO & 07-Jun-01 & 0.03 & 2.1 & $<0.04$ & 0.84 & 20 & 7.8 & 6.3 & 100 \\
\hline WCRC-BERTACCO & 12-Sep-01 & 0.08 & 2.6 & $<0.04$ & 1.1 & 20 & 7.8 & 6.2 & 110 \\
\hline WCRC-BERTACCO & 17-Dec-01 & 0.03 & 2.3 & $<0.04$ & 0.89 & 19.4 & 7.2 & 5.3 & 110 \\
\hline WCRC-BERTACCO & 13-Mar-02 & $<0.01$ & 2.6 & $<0.10$ & 0.86 & 19.3 & 7.5 & 5.7 & 110 \\
\hline WCRC-BERTACCO & 26-Jun-02 & $<0.01$ & 2.7 & $<0.10$ & 0.75 & 20 & 6.9 & 4.7 & 100 \\
\hline WCRC-BERTACCO & 18-Sep-02 & $<0.01$ & 3.1 & $<0.05$ & 0.82 & 19.7 & 7 & 6.1 & 110 \\
\hline WCRC-BERTACCO & 06-Dec-02 & 0.1 & 3.3 & $<0.05$ & 0.81 & 19.5 & 7.1 & 6 & 310 \\
\hline WCRC-BERTACCO & 03-Mar-03 & $<0.01$ & 3.2 & $<0.05$ & 1.8 & 21 & 7.5 & 5.8 & 114 \\
\hline WCRC-BERTACCO & 11-Jun-03 & $<0.01$ & 3.3 & $<0.05$ & 0.79 & 20 & 7.4 & 5.9 & 111 \\
\hline
\end{tabular}

Appendix 3: NGMP results, 1998 - 2003. Source: GNS, 2004. 


\begin{tabular}{|c|c|c|c|c|c|c|c|c|c|c|}
\hline Bore & $\begin{array}{l}\text { SAMPLE_S } \\
\text { ATE }\end{array}$ & $\overline{\text { RT_D }}$ & $\begin{array}{l}\text { SAMPLE_NU } \\
\text { MBER }\end{array}$ & $\mathrm{pH}$ & $\begin{array}{l}\text { alkalinity } \\
\text { as } \mathrm{HCO} 3-\end{array}$ & $\begin{array}{l}\mathrm{Br} \\
\text { total }\end{array}$ & $\begin{array}{l}\mathrm{Ca} \\
\mathrm{mg} / \mathrm{L})\end{array}$ & $\left(\begin{array}{l}\mathrm{Cl} \\
\mathrm{mg} / \mathrm{L})\end{array}\right.$ & $\begin{array}{l}\text { Field } \\
\mathrm{pH}\end{array}$ & \begin{tabular}{|l|} 
Field DO ( \\
$\mathrm{mg} / \mathrm{L})$
\end{tabular} \\
\hline WCRC-LYNDALE & 15-Sep-98 & $11: 30$ & 4157 & 6.7 & 48 & & 13.8 & 2.3 & & \\
\hline WCRC-LYNDALE & 15-Sep-98 & 11:30 & 6688 & & & & & & 6.05 & \\
\hline WCRC-LYNDALE & 07-Dec-98 & 16:20 & 4340 & 6.5 & 47 & & 13.6 & 2.1 & & \\
\hline WCRC-LYNDALE & 07-Dec-98 & 16:20 & 6687 & & & & & & 5.82 & 2.24 \\
\hline WCRC-LYNDALE & 02-Mar-99 & $10: 50$ & 4525 & 6.4 & 46 & & 13.3 & 2.2 & & \\
\hline WCRC-LYNDALE & 02-Mar-99 & $10: 50$ & 6689 & & & & & & & 9.61 \\
\hline WCRC-LYNDALE & 16-Jun-99 & 11:15 & 7262 & 8.2 & 43 & 0.02 & 12.7 & 2.4 & & \\
\hline WCRC-LYNDALE & 16-Jun-99 & 11:15 & 7780 & & & & & & & 4 \\
\hline WCRC-LYNDALE & 08-Sep-99 & 11:10 & 7334 & 6.4 & 39 & $<0.02$ & 11.7 & 3 & & 7.01 \\
\hline WCRC-LYNDALE & 09-Dec-99 & 11:45 & 7949 & 6.4 & 43 & $<0.03$ & 12.3 & 2.6 & 6.08 & 2.9 \\
\hline WCRC-LYNDALE & 07-Mar-00 & 13:00 & 8035 & 6.3 & 44 & $<0.03$ & & & 6.09 & 0.2 \\
\hline WCRC-LYNDALE & 07-Jun-00 & 11:45 & 8297 & 6.3 & 40 & $<0.03$ & 12.7 & 2.8 & 6.7 & 6.1 \\
\hline WCRC-LYNDALE & 18-Sep-00 & $14: 20$ & 8171 & 6.1 & 40 & $<0.03$ & & 3 & 5.84 & 2.98 \\
\hline WCRC-LYNDALE & 15-Dec-00 & $11: 45$ & 8422 & 6.2 & 42 & 0.12 & 11.9 & 2.1 & 5.78 & 3.36 \\
\hline WCRC-LYNDALE & 13-Mar-01 & $13: 30$ & 8514 & 6.1 & 42 & $<0.03$ & 11.8 & 2.7 & 6.52 & \\
\hline WCRC-LYNDALE & 11-Jun-01 & 10:51 & 9339 & 6.2 & 40 & $<0.03$ & 12 & 3.1 & & 5.77 \\
\hline WCRC-LYNDALE & 11-Sep-01 & $11: 35$ & 9491 & 6.3 & 38 & $<0.03$ & 12.3 & 3.5 & 6.77 & 4.8 \\
\hline WCRC-LYNDALE & 18-Dec-01 & $11: 30$ & 9592 & 6 & 43 & $<0.03$ & 12.8 & 2.8 & 7.46 & 2.99 \\
\hline WCRC-LYNDALE & 14-Mar-02 & $9: 15$ & 9702 & 6 & 44 & $<0.10$ & 13 & 2.4 & 5.96 & 2.97 \\
\hline WCRC-LYNDALE & 25-Jun-02 & 13:10 & 9823 & 6.2 & 40 & $<0.10$ & 12.5 & 2.9 & 5.93 & 3.76 \\
\hline WCRC-LYNDALE & 17-Sep-02 & $13: 40$ & 10274 & 6.1 & 41 & $<0.10$ & 13 & 3.3 & 4.96 & 4.4 \\
\hline WCRC-LYNDALE & 04-Dec-02 & 10:25 & 10352 & 6.4 & 42 & $<0.10$ & 12.9 & 3.2 & 6.02 & 3.9 \\
\hline WCRC-LYNDALE & 04-Mar-03 & $10: 50$ & 21404 & 6.2 & 43 & $<0.10$ & 13.9 & 2.9 & 6.95 & 4 \\
\hline WCRC-LYNDALE & 10-Jun-03 & 12:00 & 21546 & 5.9 & 40 & $<0.10$ & 13.4 & 3.6 & 5.92 & \\
\hline
\end{tabular}

Appendix 3: NGMP results, 1998 - 2003. Source: GNS, 2004. 


\begin{tabular}{|c|c|c|c|c|c|c|c|c|}
\hline Bore & $\begin{array}{l}\text { SAMPLE_ST } \\
\text { ART_DATE }\end{array}$ & $\begin{array}{ll}\text { Field } \\
\text { static } \\
\text { water } \\
\text { level } \\
\text { m ) }\end{array}$ & $\begin{array}{l}\text { Field } \\
\text { temperature } \\
\operatorname{deg}_{-} \mathrm{C} \text { ) }\end{array}$ & $\begin{array}{l}\mathrm{EC} \\
\mathrm{uS} / \mathrm{cm} \\
\mathrm{y}\end{array}$ & F ( mg/L & $\mid \begin{array}{l}\mathrm{Fe} \\
\mathrm{mg} / \mathrm{L})\end{array}$ & $\left(\begin{array}{l}\mathrm{Mg} \\
\mathrm{mg} / \mathrm{L})\end{array}\right.$ & $\begin{array}{l}M n \\
m g / L)\end{array}$ \\
\hline WCRC-LYNDALE & 15-Sep-98 & & & & & 0.02 & 1.6 & $<0.01$ \\
\hline WCRC-LYNDALE & 15-Sep-98 & 3.1 & 13.2 & 110 & & & & \\
\hline WCRC-LYNDALE & 07-Dec-98 & & & & & 0.05 & 1.5 & $<0.01$ \\
\hline WCRC-LYNDALE & 07-Dec-98 & 3.12 & 12.36 & 77 & & & & \\
\hline WCRC-LYNDALE & 02-Mar-99 & & & & & 0.07 & 1.5 & $<0.02$ \\
\hline WCRC-LYNDALE & 02-Mar-99 & 3.9 & 13.67 & 81 & & & & \\
\hline WCRC-LYNDALE & 16-Jun-99 & & & & $<0.05$ & 0.06 & 1.4 & $<0.005$ \\
\hline WCRC-LYNDALE & 16-Jun-99 & 3.6 & 13.88 & 83 & & & & \\
\hline WCRC-LYNDALE & 08-Sep-99 & 3.06 & & 12.81 & $<0.05$ & 0.028 & 1.4 & $<0.005$ \\
\hline WCRC-LYNDALE & 09-Dec-99 & 3.15 & 12.85 & 59 & $<0.05$ & 0.07 & 1.5 & $<0.005$ \\
\hline WCRC-LYNDALE & 07-Mar-00 & 3.105 & 13.8 & & 0.05 & & & \\
\hline WCRC-LYNDALE & 07-Jun-00 & 2.665 & 13.94 & 64 & $<0.05$ & $<0.02$ & 1.5 & $<0.005$ \\
\hline WCRC-LYNDALE & 18-Sep-00 & 2.97 & 12.6 & 76 & $<0.05$ & 0.024 & 1.4 & $<0.005$ \\
\hline WCRC-LYNDALE & 15-Dec-00 & 3.15 & 12.51 & & $<0.05$ & 0.025 & 1.4 & $<0.005$ \\
\hline WCRC-LYNDALE & 13-Mar-01 & 3.16 & 13.42 & 78 & $<0.05$ & $<0.02$ & 1.4 & $<0.005$ \\
\hline WCRC-LYNDALE & 11-Jun-01 & 3.18 & 13.45 & 74 & 0.05 & $<0.02$ & 1.4 & $<0.005$ \\
\hline WCRC-LYNDALE & 11-Sep-01 & 3.01 & 12.3 & 99 & $<0.05$ & $<0.02$ & 1.5 & $<0.005$ \\
\hline WCRC-LYNDALE & 18-Dec-01 & 2.8 & 14.7 & 101 & 0.02 & $<0.02$ & 1.5 & $<0.005$ \\
\hline WCRC-LYNDALE & 14-Mar-02 & 2.998 & 13.8 & 102 & 0.03 & $<0.02$ & 1.5 & $<0.005$ \\
\hline WCRC-LYNDALE & 25-Jun-02 & 2.718 & 13.6 & 95 & $<0.03$ & $<0.02$ & 1.5 & $<0.005$ \\
\hline WCRC-LYNDALE & 17-Sep-02 & 2.987 & 12.76 & & $<0.03$ & $<0.02$ & 1.5 & $<0.005$ \\
\hline WCRC-LYNDALE & 04-Dec-02 & 3.042 & 13.6 & 106 & $<0.03$ & $<0.02$ & 1.5 & $<0.005$ \\
\hline WCRC-LYNDALE & 04-Mar-03 & 2.908 & 13.4 & 164 & 0.03 & $<0.02$ & 1.7 & $<0.005$ \\
\hline WCRC-LYNDALE & 10-Jun-03 & 2.729 & 13.8 & 104 & 0.03 & $<0.02$ & 1.6 & $<0.005$ \\
\hline
\end{tabular}

Appendix 3: NGMP results, 1998 - 2003. Source: GNS, 2004. 


\begin{tabular}{|c|c|c|c|c|c|c|c|c|c|}
\hline Bore & $\begin{array}{l}\text { SAMPLE_ST } \\
\text { ART_DATE }\end{array}$ & $\begin{array}{l}\text { nitrogen } \\
\text { (ammonium) } \\
\text { as } \quad \mathrm{N} \quad- \\
\text { soluble } \quad( \\
\mathrm{mg} / \mathrm{L})\end{array}$ & \begin{tabular}{|l} 
nitrogen \\
(nitrate) as $\mathrm{N}$ - \\
total ( $\mathrm{mg} / \mathrm{L}$ )
\end{tabular} & $\begin{array}{l}\text { DRP } \\
(\mathrm{mg} / \mathrm{l})\end{array}$ & $\begin{array}{l}\text { potassium (all } \\
\text { forms) as } \mathrm{K} \text { - } \\
\text { total }(\mathrm{mg} / \mathrm{L})\end{array}$ & $\begin{array}{l}\mathrm{SiO2} \\
\mathrm{mg} / \mathrm{L})\end{array}$ & $\left(\begin{array}{l}\mathrm{Na} \\
\mathrm{mg} / \mathrm{L})\end{array}\right.$ & $\left(\begin{array}{l}\mathrm{SO} 4 \\
\mathrm{mg} / \mathrm{L})\end{array}\right.$ & $\begin{array}{l}\text { EC } \\
\text { uS/cm) }\end{array}$ \\
\hline WCRC-LYNDALE & 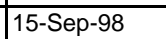 & $<0.01$ & 0.59 & $<0.1$ & 2.3 & 10 & 2.8 & 4 & 100 \\
\hline WCRC-LYNDALE & 15-Sep-98 & & & & & & & & \\
\hline \begin{tabular}{|l} 
WCRC-LYNDALE \\
\end{tabular} & \begin{tabular}{|l|}
$07-D e c-98$ \\
\end{tabular} & $<0.01$ & 0.48 & & 2.3 & 9.4 & 2.9 & 4.1 & 90 \\
\hline WCRC-LYNDALE & 07-Dec-98 & & & & & & & & \\
\hline WCRC-LYNDALE & 02-Mar-99 & $<0.01$ & 0.52 & & 2.6 & 10.3 & 2.9 & 4.2 & 70 \\
\hline WCRC-LYNDALE & 02-Mar-99 & & & & & & & & \\
\hline WCRC-LYNDALE & 16-Jun-99 & $<0.01$ & 0.82 & $<0.03$ & 2.5 & 10.5 & 2.9 & 3.4 & 80 \\
\hline WCRC-LYNDALE & \begin{tabular}{|l}
$16-J u n-99$ \\
\end{tabular} & & & & & & & & \\
\hline WCRC-LYNDALE & 08-Sep-99 & $<0.01$ & 1.1 & $<0.03$ & 2.6 & 9.3 & 2.7 & 4.9 & 90 \\
\hline WCRC-LYNDALE & 09-Dec-99 & $<0.01$ & 0.73 & $<0.04$ & 2.4 & 9.3 & 3 & 4.7 & 100 \\
\hline WCRC-LYNDALE & \begin{tabular}{|l|}
$07-M a r-00$ \\
\end{tabular} & 0.01 & 0.72 & $<0.04$ & 2.3 & & 2.8 & 4.8 & 100 \\
\hline WCRC-LYNDALE & 07-Jun-00 & $<0.01$ & 1.2 & $<0.04$ & 2.5 & 9.1 & 2.9 & 6.7 & 100 \\
\hline WCRC-LYNDALE & 18-Sep-00 & $<0.01$ & 1.1 & $<0.04$ & 2.4 & 8.7 & & & 100 \\
\hline WCRC-LYNDALE & 15-Dec-00 & $<0.02$ & 0.65 & $<0.04$ & 2.2 & 8.7 & 2.5 & 4.9 & 100 \\
\hline WCRC-LYNDALE & 13-Mar-01 & $<0.01$ & 0.68 & $<0.04$ & 2.4 & 8.9 & 2.9 & 5.7 & 90 \\
\hline WCRC-LYNDALE & 11-Jun-01 & 0.02 & 0.86 & $<0.04$ & 2.3 & 10 & 3 & 6.2 & 100 \\
\hline WCRC-LYNDALE & \begin{tabular}{|l|}
$11-$ Sep-01 \\
\end{tabular} & $<0.01$ & 1.4 & $<0.04$ & 2.1 & 9.3 & 3.2 & 6.1 & 100 \\
\hline WCRC-LYNDALE & 18-Dec-01 & 0.01 & 1.3 & $<0.04$ & 2.9 & 9.3 & 2.9 & 6.1 & 100 \\
\hline WCRC-LYNDALE & 14-Mar-02 & $<0.01$ & 1 & $<0.10$ & 2.5 & 9.1 & 2.7 & 5.4 & 100 \\
\hline WCRC-LYNDALE & 25-Jun-02 & $<0.01$ & 1.2 & $<0.10$ & 2.4 & 9.3 & 2.8 & 5.7 & 100 \\
\hline WCRC-LYNDALE & 17-Sep-02 & $<0.01$ & 1.5 & $<0.05$ & 2.3 & 8.8 & 2.7 & 6.4 & 100 \\
\hline WCRC-LYNDALE & 04-Dec-02 & $<0.01$ & 1.3 & $<0.05$ & 2.6 & 8.6 & 2.7 & 6.1 & 100 \\
\hline WCRC-LYNDALE & 04-Mar-03 & $<0.01$ & 0.94 & $<0.05$ & 2.5 & 10.4 & 2.8 & 6.2 & 101 \\
\hline WCRC-LYNDALE & 10-Jun-03 & $<0.01$ & 1.1 & $<0.05$ & 2.3 & 10.2 & 2.8 & 6.9 & 105 \\
\hline
\end{tabular}

Appendix 3: NGMP results, 1998 - 2003. Source: GNS, 2004. 